\title{
The effectiveness of environmental policies on reducing deforestation in the Brazilian Amazon
}

Citation for published version (APA):

Heuser, S. (2018). The effectiveness of environmental policies on reducing deforestation in the Brazilian Amazon. [Doctoral Thesis, Maastricht University]. Boekenplan. https://doi.org/10.26481/dis.20181120sh

Document status and date:

Published: 01/01/2018

DOI:

10.26481/dis.20181120sh

Document Version:

Publisher's PDF, also known as Version of record

\section{Please check the document version of this publication:}

- A submitted manuscript is the version of the article upon submission and before peer-review. There can be important differences between the submitted version and the official published version of record.

People interested in the research are advised to contact the author for the final version of the publication, or visit the DOI to the publisher's website.

- The final author version and the galley proof are versions of the publication after peer review.

- The final published version features the final layout of the paper including the volume, issue and page numbers.

Link to publication

\footnotetext{
General rights rights.

- You may freely distribute the URL identifying the publication in the public portal. please follow below link for the End User Agreement:

www.umlib.nl/taverne-license

Take down policy

If you believe that this document breaches copyright please contact us at:

repository@maastrichtuniversity.nl

providing details and we will investigate your claim.
}

Copyright and moral rights for the publications made accessible in the public portal are retained by the authors and/or other copyright owners and it is a condition of accessing publications that users recognise and abide by the legal requirements associated with these

- Users may download and print one copy of any publication from the public portal for the purpose of private study or research.

- You may not further distribute the material or use it for any profit-making activity or commercial gain

If the publication is distributed under the terms of Article $25 \mathrm{fa}$ of the Dutch Copyright Act, indicated by the "Taverne" license above, 


\section{The Effectiveness of Environmental \\ Policies on Reducing Deforestation in \\ the Brazilian Amazon}

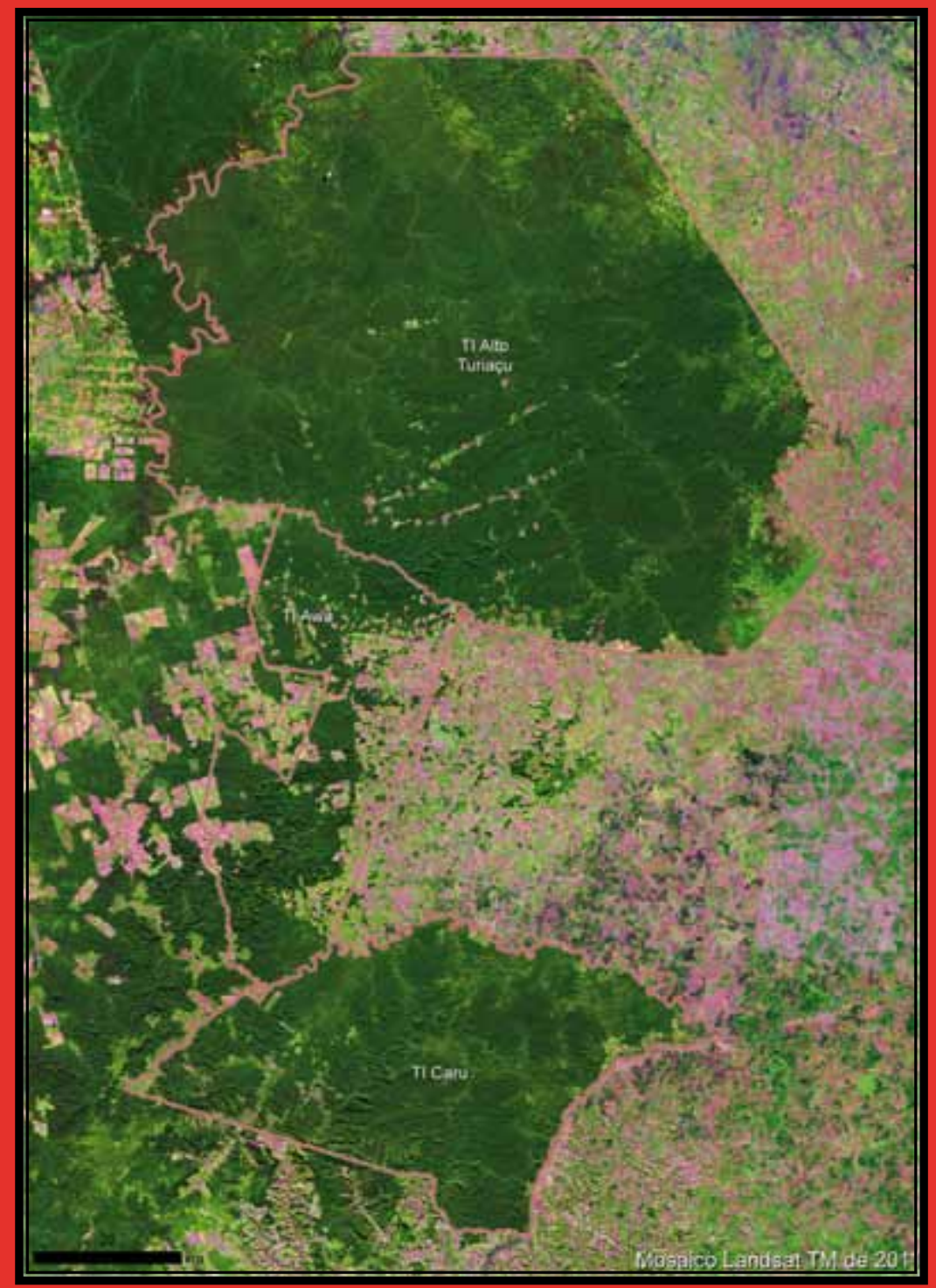

\section{Silke Heuser}





\section{The Effectiveness of Environmental Policies on Reducing Deforestation in the Brazilian Amazon}


ISBN: 9789086664597

Publisher: Boekenplan, Maastricht

All rights reserved. No part of this publication may be reproduced, stored in a retrieval system, or transmitted in any form, or by any means, electronic, mechanical, photocopying, recording, or otherwise, without the prior permission in writing, from the author.

The picture on the cover page was provided by the Deutsche Gesellschaft für Internationale Zusammenarbeit (GIZ). It shows a satellite picture of the indigenous territories of Alto Turiaçu and Caru in Maranhão. 


\title{
The Effectiveness of Environmental Policies on Reducing Deforestation in the Brazilian Amazon
}

\author{
DISSERTATION \\ To obtain the degree of Doctor \\ at Maastricht University, \\ on the authority of the Rector Magnificus \\ Prof. Dr. Rianne M. Letschert \\ in accordance with the decision of the Board of Deans \\ to be defended in public \\ on Tuesday, 20 November 2018 at 16:00 hours
}

by

Silke Heuser 


\section{Supervisors:}

Prof. Dr. Cathal O'Donoghue

Prof. Dr. Ronald Skeldon

\section{Co-supervisor:}

Prof. Dr. Jan Börner, Institute for Food and Resource Economics, University of Bonn and Center for Development Research

Assessment Committee:

Prof. Dr. René Kemp (Chairman)

Prof. Dr. Eva Terberger (University of Mannheim)

Dr. Eleonora Nillesen

Dr. Mary Ryan (Teagasc, Agriculture and Food Development Authority, Galway, Ireland)

Dr. Georg Winkel (EFI Unit, Bonn) 


\section{ACKNOWLEDGMENTS}

My interest in the topic of this dissertation arose from speaking with indigenous peoples in the Brazilian Amazon. While working at KfW Development Bank, I evaluated the Indigenous Lands Project, on which part of this dissertation is based. While working on this dissertation, I published one paper, submitted a second one, and planned the submission of a third one, cooperating with several co-authors. Table 1 provides an overview of the sources and contributors for each chapter. I would like to express my gratitude to the co-authors, supervisors, members of the assessment committee, reviewers, and discussants for making the publications and this dissertation possible.

Table 1. Overview of contributors to this dissertation

\begin{tabular}{|c|l|}
\hline CHAPTER/SECTION & CONTRIBUTORS \\
\hline Chapter $\mathbf{1}$ & \\
\hline 1) Funding & Silke Heuser \\
\hline 2) RQ and design stage & Silke Heuser \\
\hline 3) Data collection & Silke Heuser \\
\hline 4) Data analysis & Silke Heuser \\
\hline 5) Write up & Silke Heuser \\
\hline Chapter 2 & \\
\hline 1) Funding & KfW Development Bank \\
\hline 2) RQ and design stage & Silke Heuser \\
\hline 3) Data collection & Silke Heuser \\
\hline 4) Data analysis & Silke Heuser \\
\hline 5) Write up & Silke Heuser \\
\hline Chapter 3 & \\
\hline 1) Funding & KfW Development Bank \\
\hline 2) RQ and design stage & Silke Heuser, Ariel BenYishay \\
\hline 3) Data collection & Silke Heuser \\
\hline 4) Data analysis & Silke Heuser, Ariel BenYishay, Daniel \\
& Runfola, Rachel Trichler \\
\hline 5) Write up & Silke Heuser and Ariel BenYishay \\
\hline
\end{tabular}




\begin{tabular}{|c|l|}
\hline Chapter $\mathbf{4}$ & \\
\hline 1) Funding & Silke Heuser \\
\hline 2) RQ and design stage & Silke Heuser \\
\hline 3) Data collection & Silke Heuser \\
\hline 4) Data analysis & Silke Heuser \\
\hline 5) Write up & Silke Heuser \\
\hline \hline Chapter 5 & \\
\hline 1) Funding & Silke Heuser \\
\hline 2) RQ and design stage & Silke Heuser \\
\hline 3) Data collection & Silke Heuser and Elias Cisneros \\
\hline 4) Data analysis & Silke Heuser and Elias Cisneros \\
\hline 5) Write up & Silke Heuser \\
\hline Chapter $\mathbf{6}$ & \\
\hline 1) Funding & Silke Heuser \\
\hline 2) RQ and design stage & Silke Heuser \\
\hline 3) Data collection & Silke Heuser \\
\hline 4) Data analysis & Silke Heuser \\
\hline 5) Write up & Silke Heuser \\
\hline
\end{tabular}




\section{PREFACE}

I am grateful for the opportunity and privilege of completing this dissertation. The research it represents was supported by a large community of scholars and professors associated with Maastricht University, staff members and managers of the World Bank and KfW, and officials of the Brazilian government, as well as indigenous organizations and communities, and family and friends. I am deeply indebted to all of them for their inspiration and support.

I am particularly grateful for the support I received from Jan Börner, Cathal O’Donoghue, and Ronald Skeldon, the advisory team that guided me through the dissertation process. Nothing would have been accomplished without Program Director Mindel van de Laar, who removed roadblocks along the way. Many professors, researchers, and staff members at Maastricht University were always ready to answer questions. I am particularly grateful for the time and support of Saba Afeworki, Johan van Amersfoort, Neil Foster-McGregor, Franziska Gassmann, Francesco Iacoella, Mary Kaltenberg, Charlotte Keijser, René Kemp, Michal Natorski, Eleonora Nillesen, Herman Pijpers. Jessica Slijkhuis, Nyasha Tirivayi, as well as Cosmin Corendea from UNU-EHS. My cohort of GPAC2 2015 and all the other fellows I met over the course of the three years will always stay close to my heart. I would especially like to acknowledge Erich De La Fuente, Ahmed Mah, Ornsaran Pomme Manuamorn, and Kenroy Roach, who helped me narrow my research topic and with whom I spent unforgettable moments in Maastricht and Washington, D.C. A special thank you goes to Omar Rodríguez, who patiently guided me in the statistical analysis, as well as Pui Hang Wong, whose expertise in R greatly helped the analysis. A special thank you also to Ariel BenYishay, Daniel Runfola, and Rachel Trichler my co-authors for chapter three of this dissertation. That chapter was published in the Journal of Environmental Economics and Management in 2017. Seth Goodman played a key role in processing the satellite and covariate data; Alec Shobe and Aishwarya Venkat provided excellent research assistance at AidData. I am grateful for their skill, dedication, and willingness to share their expertise. Another special thank you goes to Elias Cisneros from Bonn University and Britaldo Soares-Filho who provided the data for chapter five of this dissertation and to Jan Börner and Elias Cisneros, who guided me in the analysis.

I owe this dissertation project to Ronald S. Parker from the World Bank and Eva Terberger from KfW whose ideas, advice, and encouragement, as well as the opportunities they created 
enabled and contributed to the completion of this project. I cannot thank them enough. Another big thank you goes to Bill Hurlbut for inspiring me during our breakfasts at the World Bank and for helping this dissertation to look great and read better. I am also grateful to Ken Chomitz, who worked on Brazil at the World Bank and who recommended me to the Dual Career program in Maastricht.

I also thank FUNAI, especially Artur Nobert Mendes, Dan Pasca, Juliana Sellani, as well as Roberto Maldonado (WWF) and Sebastian Weber (KfW) who made it possible to obtain the project data for chapter three. I also thank the Brazilian government officials, nongovernmental organizations, and indigenous communities I met during my fieldwork. I also would like to acknowledge two anonymous reviewers from the Journal of Environmental Economics and Management as well as Eva Terberger, Ken Chomitz, Priya Mukherjee, Brad Parks, Kate Sims, participants in the $18^{\text {th }}$ BIOECON conference in September 2016, as well as representatives of the World Bank's Independent Evaluation Group, United States Agency for International Development, and the College of William \& Mary, all of whom provided helpful comments.

A heartfelt thank you goes to my husband Anthony and my daughter Cecilia who patiently spent many weekends playing together. This thank you extends to my parents and siblings who supported and encouraged me along the way. 


\section{ACRONYMS AND ABBREVIATIONS}

ACT

AidData

$\mathrm{AM}$

APITEM

ARPA

$\mathrm{BCB}$

BIOECON

$\mathrm{BMZ}$

BRICS

BRL

CAR

CIA

CIESIN

CIMI

$\mathrm{CMN}$

$\mathrm{CO}_{2}$

COIAB

DETER

FAO

FOCIMP

FUNAI

GDP

GIMMS

GIZ
Amazon Conservation Team

Research and innovation lab at the College of William \& Mary

Amazonas state in the Brazilian Amazon

Associação do Povo Indígena Tenharim Morõgwitá (Brazilian NGO)

Amazon Region Protected Areas project

Banco Central do Brasil (Central Bank of Brazil)

Biodiversity and Economics for Conservation (Annual Conference)

Federal Ministry of Economic Cooperation and Development

(Germany)

Association of five major emerging national economies: Brazil, Russia, India, China, and South Africa

Brazilian Real

Cadastro Ambiental Rural (Rural environmental registry system)

Central Intelligence Agency (United States)

Center for International Earth Science Information Network, Columbia University

Conselho Indigenista Missionário (Brazilian NGO)

Conselho Monetário Nacional (National Monetary Council)

Carbon dioxide

Coordenação das Organizações Indígenas da Amazônia Brasileira

(Brazilian NGO)

Real-Time System for Detection of Deforestation

Food \& Agriculture Organization

Federação das Organizações e Comunidades Indígenas do Médio

Purus (Brazilian NGO)

Fundação Nacional do Índio (National Indian Foundation)

Gross domestic product

Global Inventory Modeling and Mapping Studies

Deutsche Gesellschaft für Internationale Zusammenarbeit GmbH

(German Development Agency) 
GPAC2 Dual Career Training Programme to obtain a PhD in Governance and Policy Analysis

GPS

Global Position System technology

GPW

Gridded Population of the World

Gt

Gigatons

IBAMA

Instituto Brasileiro do Meio Ambiente e dos Recursos Naturais

Renováveis (Brazilian Institute of the Environment and Renewable

Natural Resources)

IBGE

Instituto Brasileiro de Geografia e Estatística (Brazilian Institute of

Geography and Statistics)

IBGE-PAM

Produção Agrícola Municipal

ICMBio

Instituto Chico Mendes de Conservação da Biodiversidade (Chico

Mendes Institute for the Conservation of Biodiversity)

ILO

International Labor Organization

INCRA

Instituto Nacional de Colonização e Reforma Agrária (National

Agency for Land Reform)

INPE

Instituto Nacional de Pesquisas Espaciais (National Institute of Space

Research)

IPAM

Instituto de Pesquisa Ambiental da Amazônia (Amazon Environmental

Research Institute)

IPCC

Intergovernmental Panel on Climate Change

IPW

Inverse propensity score weighting

ISA

Instituto Socioambiental

JEEM

Journal of Environmental Economics and Management

JOCUM

Jovens com uma Missão (Brazilian NGO)

KfW

Kreditanstalt für Wiederaufgbau (German Development Bank)

$\mathrm{km}^{2}$

Square kilometer

LTDR

Land Long-Term Data Record

MOP

Memorandum and Recommendations of the Director of the Latin

America and the Caribbean Department

NASA

National Aeronautics and Space Administration (United States)

NDVI

Normalized Difference Vegetation Index

NGO

Nongovernmental organization

OPAN

Operação Amazônia Nativa (Brazilian NGO) 
OPIMP Organização dos Povos Indígenas do Médio Purus (Brazilian NGO)

OPITTAMPP Organização dos Povos Indígenas Torá, Tenharim, Apurinã, Mura, Parintintin e Pirahã (Brazilian NGO)

PAC Programa de Aceleração do Crescimento (Growth Acceleration Program)

PEVS

PNGATI

PPCDAM

PPG7

PPTAL

$\mathrm{R} \$$

SIL

SLAPR

SoyM

SRTM

UEA

UN

UNDP

USAID

USD

USGS

WRI
Produção da Extração Vegetal e da Silvicultura | Estatísticas (IBGE)

Política Nacional de Gestão Ambiental e Territorial de Terras

Indígenas (National Policy on Environmental and Territorial

Management of Indigenous Lands)

Action Plan to Combat Deforestation in the Amazon (Portuguese acronym)

Pilot Programme to Conserve the Brazilian Rainforest

Projeto Integrado de proteção às Populações e Terras Indígenas da Amazônia Legal (Rain Forest Indigenous Lands Project)

Reis (Brazilian currency)

Mission Sociedade Internacional de Lingüística (International Association of Linguistics)

Mato Grosso system for the environmental licensing of rural properties

(Portuguese acronym)

Soy Moratorium

NASA Shuttle Radar Topography Mission

Universidade Estadual do Amazonas (Amazonas State University of Manaus)

United Nations

United Nations Development Programme

United States Agency for International Development

U.S. Dollar

U.S. Geological Survey

World Resources Institute 



\section{CONTENTS}

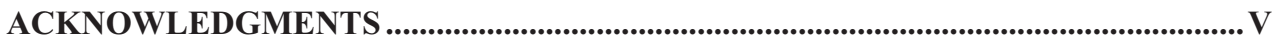

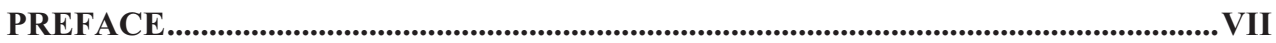

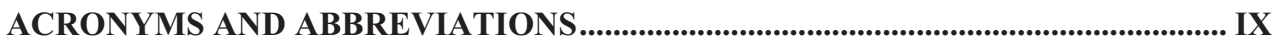

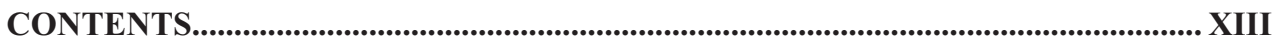

1 EXPLAINING THE DRAMATIC DECLINE IN DEFORESTATION IN

BRAZIL'S AMAZON RAINFOREST ...................................................................1

$1.1 \quad$ A Test of Conservation Versus Development .................................................. 1

1.1.1 Theoretical Underpinnings of Deforestation .................................................. 3

1.1.2 Rapid Decline in Deforestation in Brazil.................................................... 8

1.1.3 Brazil Commits to Deforestation Agreements .............................................. 11

1.1.4 Providing Indigenous Communities with Land Rights as a Way to Protect

Forests 12

1.2 Gaps in the Current Research Literature on Deforestation in Brazil........................ 14

1.2.2 Overarching Research Question and Sub-Questions .....................................23

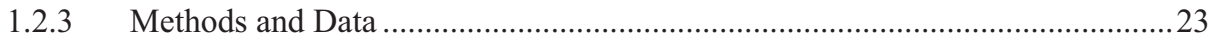

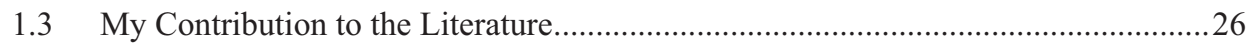

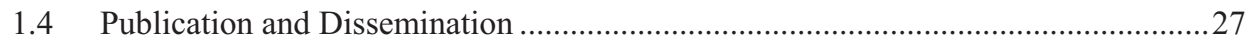

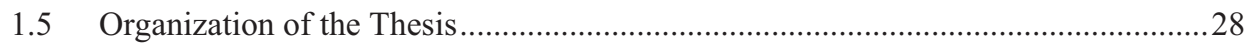

2 INDIGENOUS PEOPLES, LAND DEMARCATION, AND ENFORCEMENT.....29

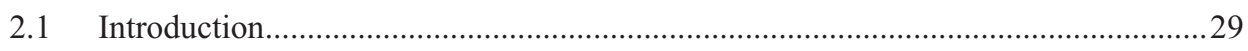

2.1.1 Results Framework for Exploring Links Between Demarcation and Monitoring

Support and Livelihoods Opportunities and the Survival of Indigenous Peoples.............32

2.2 Exploring the Survival of Indigenous Peoples in Indigenous Territories Fills a Gap

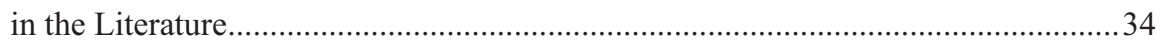

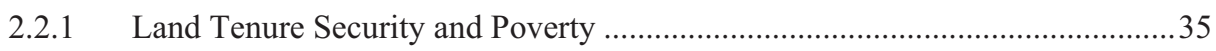


2.2.2 Research Gap 36

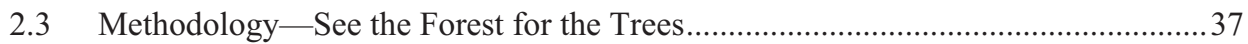

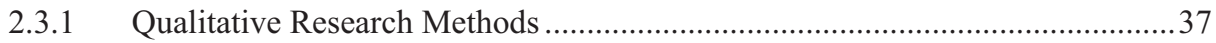

2.3.2 Focus Group Methodology and Observation ................................................. 38

2.3.3 Selection Criteria for Field-Based Case Studies ............................................... 41

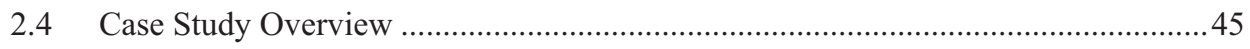

2.4.1 Data Collection Context.............................................................................. 45

2.4.2 Case Study 1-Indigenous Territory Paumari do Lago Marahã ........................46

2.4.3 Case Study 2 - Indigenous Territory Jarawara/Jamamadi/Kanamati .................48

2.4.4 Case Study 3-Indigenous Territory Tenharim/Marmelos ................................50

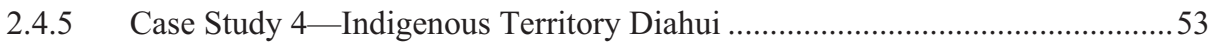

2.5 Case Study Results_-Demarcation, A Blessing or Curse ......................................55

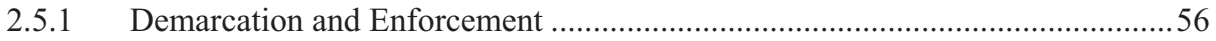

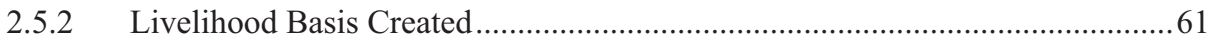

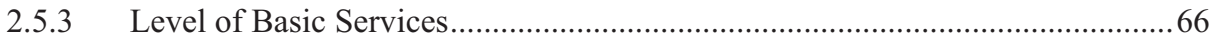

2.5.4 Do Indigenous Peoples Actually Live in Indigenous Territories? .....................68

2.6 Discussion and Policy Implications ................................................................... 78

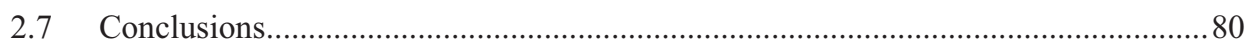

3 THE IMPACT OF DEMARCATION ON FOREST PRESERVATION .................83

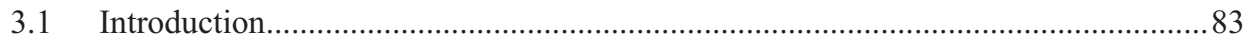

3.2 Indigenous Land Rights and Deforestation: Evidence from the Brazilian

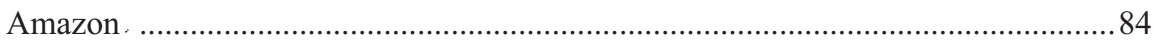

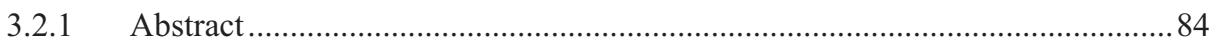

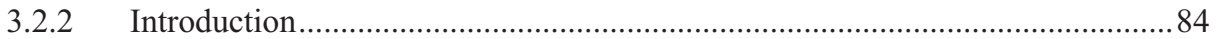

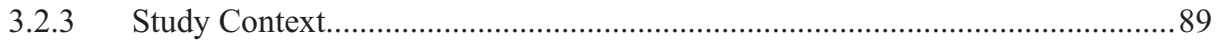

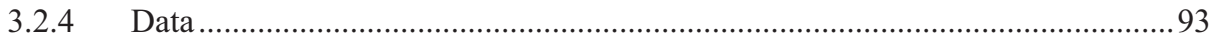

3.2.5 Grid Cell-Year Panel Model …................................................................... 98 
3.2.6 Robustness Checks

3.3 Conclusions

3.4 Policy Relevance in the Context of this Dissertation

4 COMPARING EFFECTS OF INDIVIDUAL ENVIRONMENTAL POLICIES ..121

4.1 Comparing Different Environmental Policies in Brazil ........................................ 122

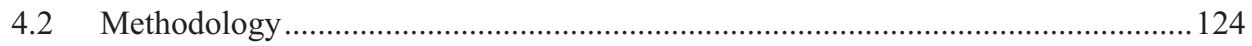

4.2.1 Identifying Selected Papers Using a Systematic Review Approach.

4.3 Impact Pathways and Literature Review_-Linking the Effect of an Environmental Policy to Deforestation

4.4 Potential Risks of Bias in Selected Papers

4.5 How to Make Different Effect Sizes Comparable.

4.6 Data and Summary Statistics - How Non-Standardized Effect Sizes Compare ..... 138

4.7 Results - Comparison of Standardized Effect Sizes.

4.8 Discussion and Conclusions-Effect Sizes for Tropical Forest Conservation Programs Tend to be Relatively Small on Average.

5 Environmental policies as drivers of forest conservation-an econometric approach

5.1 Introduction.

5.2 Theory and Literature Review_-Linking Environmental Policies with Deforestation.

5.2.1 Context

5.2.2 Theoretical Impact Pathways of Different Environmental Policy

Mechanisms 154

5.2.3 Interlinkages between the Eight Environmental Policies

5.3 Econometric Models on Deforestation in the Literature

5.4 Methodology_Using a Panel Model to Account for Policies as Drivers of Forest Conservation

5.4.1 Measurement of Indicators 
5.4.2 Data Models 165

5.4.3 Principal Component Analysis 169

5.5 Data and Summary Statistics - Introducing Policy Variables and the Deforestation Model.

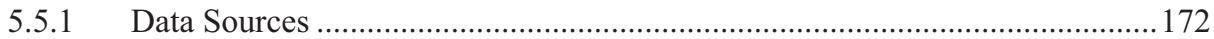

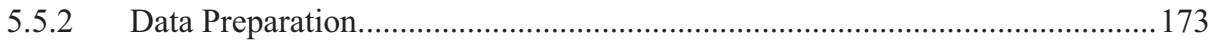

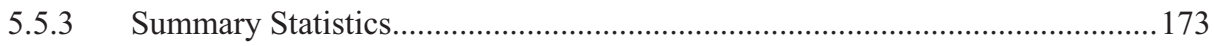

5.6 Results - The Marginal Effect of Eight Environmental Policies on Deforestation is

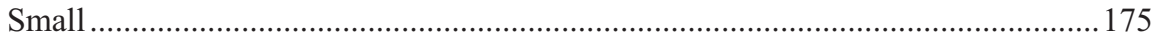

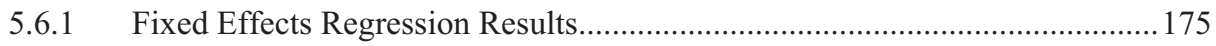

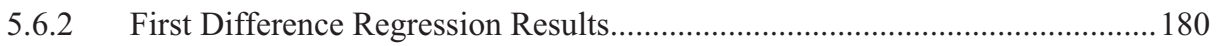

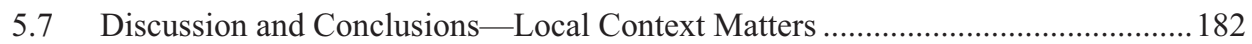

6 THE WAY AHEAD IN UNDERSTANDING THE SUDDEN DECLINE IN DEFORESTATION.............................................................................................. 185

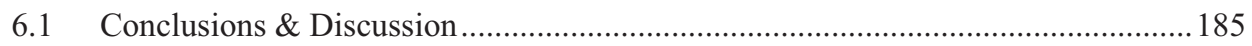

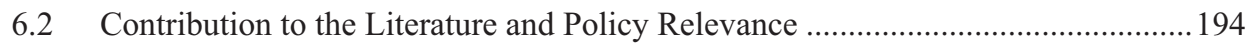

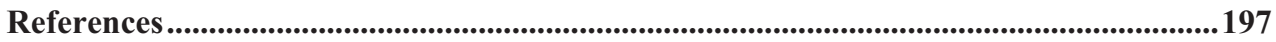

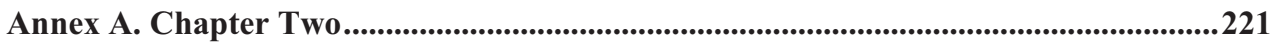

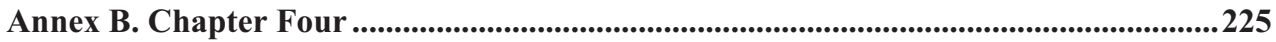

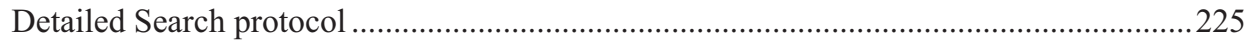

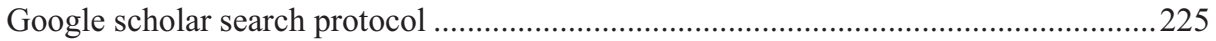

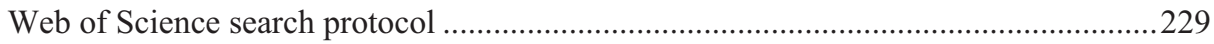

Annex C. Chapter Five .....................................................................................................................2235

Annex D. Addendum on Valorization of the Dissertation.............................................250

Annex E. Summary of the Thesis ..................................................................................................253

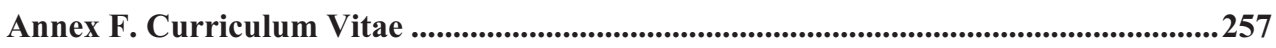

Annex G. UNU-MERIT/MGSoG Dissertation Series...................................................259 


\section{Figures}

Figure 1. Von Thünen model adapted for the Brazilian Amazon............................................ 4

Figure 2. Agricultural and forest rents and forest rent capture ............................................. 4

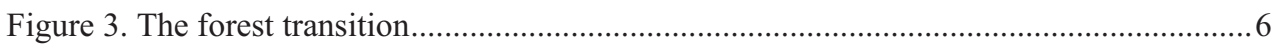

Figure 4. Annual area deforested $\left(\mathrm{km}^{2}\right)$ in the Brazilian Amazon, 1995-2015 ..................... 9

Figure 5. Estimated remaining forest cover in the Brazilian Amazon $\left(\mathrm{km}^{2}\right), 1995-2015 \ldots \ldots . . .9$

Figure 6. Annual area deforested $\left(\mathrm{km}^{2}\right)$ in the Brazilian Amazon, 1995-2015, and GDP growth rate for Brazil

Figure 7. Population growth in northern Brazil (Rondônia, Acre, Amazonas, Roraima, Pará, Amapá, Tocantins states) compared with Brazil, 1980-2010

Figure 8 . Half of the decline in deforestation can be explained by environmental policies and the other half by economic drivers of deforestation

Figure 9. Results framework

Figure 10. Von Thünen model adapted for indigenous communities in the Brazilian Amazon

Figure 11. Number of indigenous territories by Brazilian state.

Figure 12. Population pyramids for indigenous people in Brazil and the Northern region.....69

Figure 13. Population pyramids for indigenous people in the Northern region living in indigenous territories compared with those living outside indigenous territories 70

Figure 14. Population pyramids for non-indigenous people in Brazil and the Northern region

Figure 15. Number of indigenous people living in indigenous territories demarcated under the

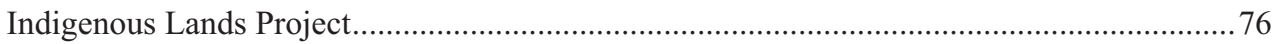

Figure 16. Demarcation year and NDVI pre-trend, at community level ..............................93

Figure 17. Comparison imagery from Manicoré Region, Brazil ...........................................95

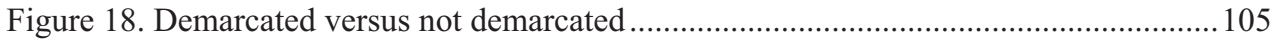

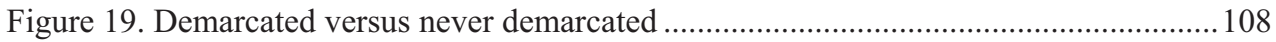

Figure 20. Impact pathways of five environmental enforcement and access restriction policies

Figure 21. Systematic review: Comparing effect sizes in the literature for five environmental policies in the Brazilian Amazon 143

Figure 22. The overlapping environmental policies in the Brazilian Amazon 158 
Figure 23. Impact pathways of eight environmental enforcement and access restriction policies

Figure 24. Plot of Eigenvalues of eight environmental policy variable correlation matrix... 170

Figure 25. Impact pathways of environmental enforcement and access restriction policies. 244

\section{Maps}

Map 1. Indigenous territories demarcated under the Indigenous Lands Projects

Map 2. Four selected case study indigenous territories demarcated under the Indigenous

Lands Project with state boundaries

Map 3. Indigenous territory Paumari do Lago Marahã - Remote location far from the agricultural frontier

Map 4. Indigenous territory Jarawara/Jamamadi/Kanamati-Remote location far from the

agricultural frontier

Map 5. Indigenous territory Tenharim/Marmelos-Proximity to a major road and to an agricultural frontier

Map 6. Indigenous territory Diahui-Proximity to a major road and within the boundaries of

a farm that was evicted during the demarcation process

Map 7. PPTAL Communities

\section{Photos}

Photo 1. Outpost house at the entrance to the indigenous territory of Paumari do Lago Marahã

Photo 2. Traditional dances in the indigenous territory of the Paumari do Lago Marahã ....... 48

Photo 3. Land demarcation through GPS mapping, panels, and demarcation stones..............56

Photo 4. Two young men on their way to hunt while patrolling the area and boat .................58

Photo 5. Toll collection along the Trans-Amazonian Highway .............................................62

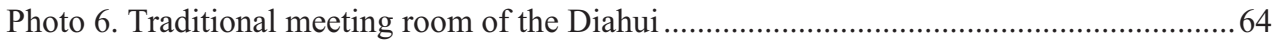

\section{Tables}

Table 1. Overview of contributors to this dissertation...........................................................

Table 2. Number of participants per focus group ............................................................. 38

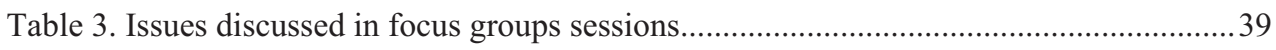

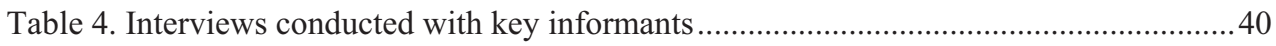

Table 5. Selected indigenous territories for case studies that were demarcated under the PPTAL project 
Table 6. Selection criteria to identify four indigenous territories for case studies 45

Table 7. Physical characteristics of the Tenharim/Marmelos indigenous territories .52

Table 8. Physical characteristics of the Diahui indigenous territory .55

Table 9. Comparing migration movements among the different indigenous communities.....73 Table 10. Average annual population growth rates for indigenous and non-indigenous people living in urban versus rural areas, 1991/2000 and 2000/2010.... .74

Table 11. Population growth of indigenous people in case study indigenous lands. .77

Table 12. Population distribution by gender for three indigenous territories .78

Table 13. Summary statistics for LTDR grid cell-level panel dataset, weighted by community size.

Table 14. LTDR grid cell-year panel model results . ....................................................... 100

Table 15. LTDR grid cell-year panel model results with post-2004 interaction ................... 104

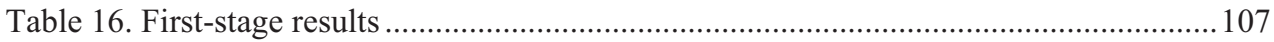

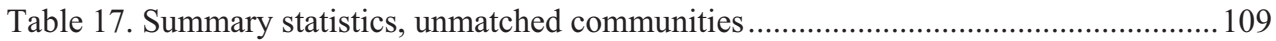

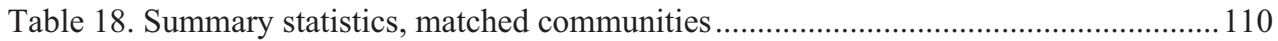

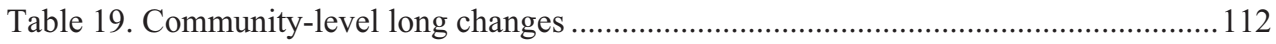

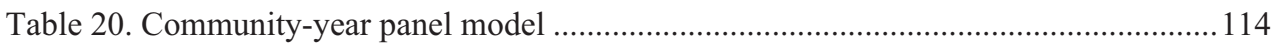

Table 21. Summary statistics for GIMMS grid cell-level panel, weighted by community size

Table 22. GIMMS cell-year panel, weighted by community size ......................................116

Table 23. Never versus ever demarcated, median NDVI ..................................................... 117

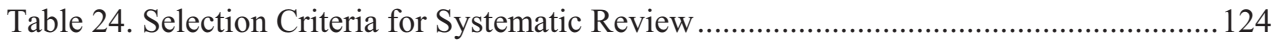

Table 25. Keyword Search Results ............................................................................... 126

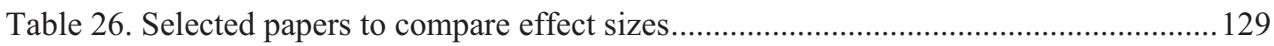

Table 27. Papers selected for the systematic review with their methodological focus, main findings, and effect size

Table 28. Effect size and standard error for making the results from selected papers comparable

Table 29. Principal components for environmental policy variables

Table 30. Summary statistics on regression variables

Table 31. First difference and fixed effects model results assessing the marginal effect of eight environmental policies on deforestation

Table 32. Comparing physical characteristics of the case study indigenous territories 
Table 33. Comparing different indigenous communities according to their self-organization

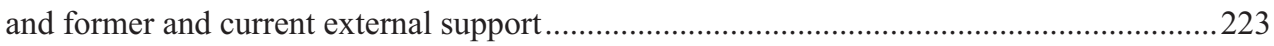

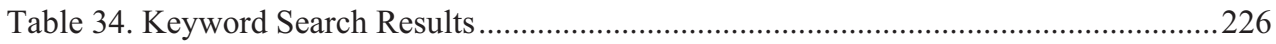

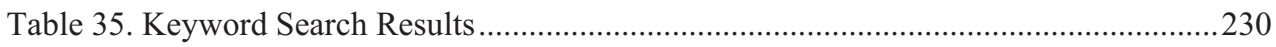

Table 36. Environmental policies and their implementation mechanisms ...........................235

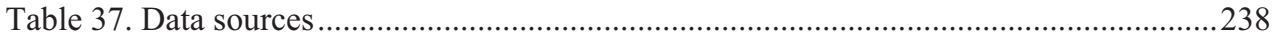

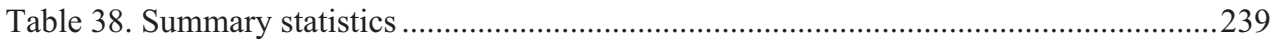

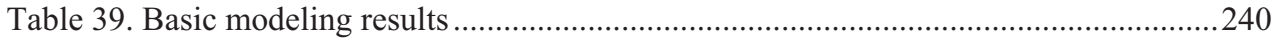

Table 40. Modeling results for the eight environmental policies ........................................242 


\title{
1 EXPLAINING THE DRAMATIC DECLINE IN DEFORESTATION IN BRAZIL'S AMAZON RAINFOREST
}

\subsection{A Test of Conservation Versus DeVelopment}

"The first person who, having enclosed a plot of land, took it into his head to say this is mine and found people simple enough to believe him was the true founder of civil society. What crimes, wars, murders, what miseries and horrors would the human race have been spared, had someone pulled up the stakes or filled in the ditch and cried out to his fellow men: "Do not listen to this imposter. You are lost if you forget that the fruits of the earth belong to all and the earth to no one!"

\author{
Jean-Jacques Rousseau
}

Rousseau's thoughts about a harmonious natural world lost to land ownership resonate today in Brazilian society and in the world at large. In Brazil, the desire to own and develop rainforest land is in tension with the need to protect it as a global public good for future generations. Brazil's government has chosen to pursue both goals at the same time, with each alternately dominating the other.

The tension between economic development and natural resource preservation reflects a global conundrum that is becoming more and more pressing in the face of climate change. How can the world, especially forest-rich developing countries and emerging economies, preserve their natural resources, including tropical forests, while also lifting poor, forest-dependent people out of poverty?

On one hand, poor countries and the low-income sections of their populations often rely on natural resources for their incomes. On the other, the international community wishes to promote conservation of tropical forests. Simultaneously conserving the forest and creating livelihoods for residents in an environmentally friendly manner would, at least theoretically, create a situation where all parties benefit.

In the international development community, policies designed to achieve both goals have had mixed results. In order to make optimal choices, we need an improved understanding of environmental policies' effects on the drivers of deforestation. Such an understanding can 
inform decisions to pursue particular actions, calibrate them more appropriately, or alternatively, refrain from them altogether. This dissertation seeks to make a contribution to this process by evaluating certain environmental policies in the Brazilian Amazon.

In order to facilitate that evaluation, it is useful to clarify certain key concepts at the outset: deforestation, drivers of deforestation, forest policy, protected areas, and land tenure. This dissertation will make repeated reference to these terms.

The United Nations Food and Agriculture Organization (FAO) defines 'deforestation' as “the conversion of forest to other land use or the long-term reduction of the tree canopy cover below the minimum 10 percent threshold."1

The literature on deforestation focuses on 'drivers of deforestation.' According to the United Nations Programme on Reducing Emissions from Deforestation and Forest Degradation, drivers of deforestation are defined as "the direct and indirect causes of forest conversion. These vary in scale from local pressures to global macroeconomic incentives and are often the product of complex interactions between social, environmental and political factors." 2 The literature on drivers of deforestation is discussed in the literature review section of this dissertation.

The FAO defines 'forest policy' as a set of orientations and principles of actions "adopted by public authorities in harmony with national socio-economic and environmental policies in a given country to guide future decisions in relation to the management, use and conservation of forest and tree resources for the benefit of society." "I use the terms "forest policy" and "environmental policy" interchangeably in this dissertation.

According to the International Union for Conservation of Nature (IUCN 2008), a 'protected area' is a "clearly defined geographical space, recognized, dedicated and managed, through legal or other effective means, to achieve the long-term conservation of nature with associated ecosystem services and cultural values."4 The IUCN further defines a number of areas with

\footnotetext{
${ }^{1}$ Retrieved on July 12, 2018, from: http://www.fao.org/docrep/017/ap862e/ap862e00.pdf.

${ }^{2}$ Retrieved on July 12, 2018, from: https://theredddesk.org/encyclopaedia/drivers-deforestation/.

${ }^{3}$ Retrieved on July 12, 2018, from: http://www.fao.org/docrep/017/ap862e/ap862e00.pdf.

${ }^{4}$ Retrieved on July 16, 2018, from: https://www.iucn.org/theme/protected-areas/about.
} 
varying degrees of protection: strictly protected areas, sustainable use areas, and indigenous territories.

The FAO defines land tenure as the "relationship, whether legally or customarily defined, among people, as individuals or groups, with respect to land."5 In this dissertation, I focus on indigenous land rights to collectively owned land. In Brazil, indigenous land rights are guaranteed by the country's 1988 Constitution.

\subsubsection{Theoretical Underpinnings of Deforestation}

Two theoretical models are especially relevant to understanding deforestation. They reflect tensions in Brazilian society, and the world more generally, between the desire to exploit forested land for agriculture and economic development, and the equally compelling desire to preserve forests for the greater public good.

The first theory is the von Thünen ${ }^{6}$ theory (von Thünen 2009 and Angelsen 2010), and the second is the forest transition theory.

The von Thünen theory's model consists of concentric circles around a marketplace. The farther away from the marketplace farmers produce products, the higher the transportation costs and the more expensive the product. There comes a point where agricultural production is not profitable any more, and from this point onward the forest is left standing (see Figure 1). The area is uniform in climate, soil, and landforms. The model is based on the assumption of an isotropic plain, meaning that there are no mountains, rivers, or roads crossing the plain.

\footnotetext{
${ }^{5}$ Retrieved on July 16, 2018, from: http://www.fao.org/docrep/005/y4307e/y4307e05.htm.

${ }^{6}$ Von Thünen, Johann Heinrich, 1783-1850.
} 
Figure 1. Von Thünen model adapted for the Brazilian Amazon

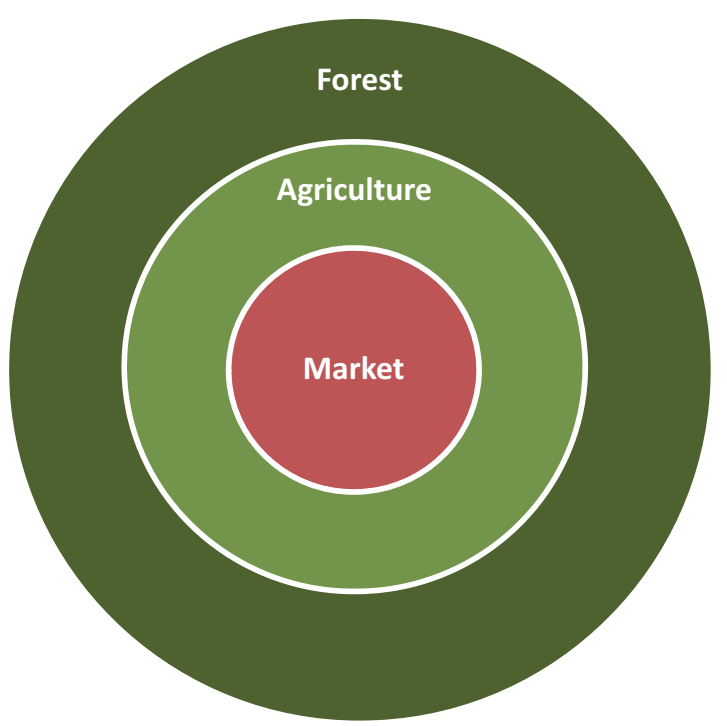

Source: Adapted from Angelsen 2007 and Fontes et al. 2017.

Based on the von Thünen theory, Angelsen (2010) developed a model where land has only two uses, either as agricultural land or as forest land (Figure 2).

Figure 2. Agricultural and forest rents and forest rent capture

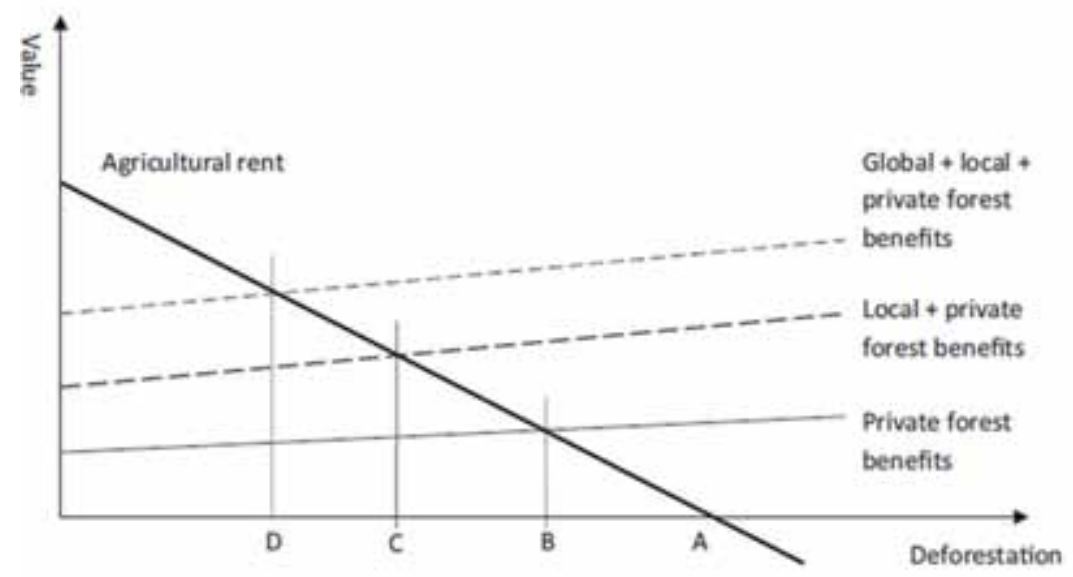

Source: Adapted from Angelsen (2010). 
Agricultural land use (extractive forest rent): According to Angelsen (2010), agricultural expansion into the forest will occur until the production costs are too high for the products to be profitable. This means that higher prices for agricultural products, technological innovations that lower production costs, better roads that lower transportation costs, better access to credit, and lower interest rates all increase deforestation. The model also indicates that higher wages and poor road conditions decrease deforestation.

Forest land use (protective forest rent): Angelsen (2010) distinguishes between several types of forest land uses: (1) private use, such as timber; (2) local public goods, such as environmental services; and (3) global public goods, such as capturing carbon and preserving biodiversity (Angelsen 2010, p. 19639). The farmer or private owner of forest land will not automatically take into consideration local and public good benefits of forests. Therefore, the farmer would deforest up to point B in Figure 2. To include local or global goods considerations, the farmer should deforest only up to point $\mathrm{C}$ (which includes local and private benefits) or up to point $\mathrm{D}$ (which includes global, local, and private forest benefits). The individual farmer would not preserve forests on his own. He needs incentives or sanctions, such as political interventions that promote the global public good and preserve forests.

Although the von Thünen theory and its elaboration in Angelson's model involve simplifying assumptions, they illuminate how market forces may shape the extent of deforestation. The theory acknowledges that certain policies may be necessary to confront the externalities of deforestation.

The second theory relevant for this dissertation is the forest transition theory, which pays limited attention to the role of forest policies. Instead, forest transition theory views urbanization as a key factor in reducing stress on forests and slowing their conversion into agricultural land. Rudel et al. (2005, p. 23) state that forest transitions occur "when declines in forest cover cease and recoveries in forest cover begin," and other authors describe forest transition as an environmental Kuznets curve, an inverted U-shaped curve to depict changes in forest cover (Mather et al. 1999 and Ehrardt-Martinez et al. 2002).

Rudel et al. (2005, p. 24) describe two paths along which forests make this transition, the "economic development path" and "the forest scarcity path."

Economic development path: Rudel et al. (2005) describe the economic development path as a transition from an agriculture-dependent society to an urbanized society. According to this 
path, farm workers abandon their fields and move into cities in search of higher-paying jobs. The cost of labor increases and agricultural production becomes unprofitable. The vacated fields recover, and the forest grows back.

Forest scarcity path: In some locations populations will grow, degrading and depleting forests. Where wood cannot be imported, the price of wood will increase, and farmers will plant trees instead of crops, leading to the recovery of the forest.

Figure 3 illustrates forest transition theory as described by Rudel et al. 2005, following the path of forests being depleted up to a point and then recovering.

\section{Figure 3. The forest transition}

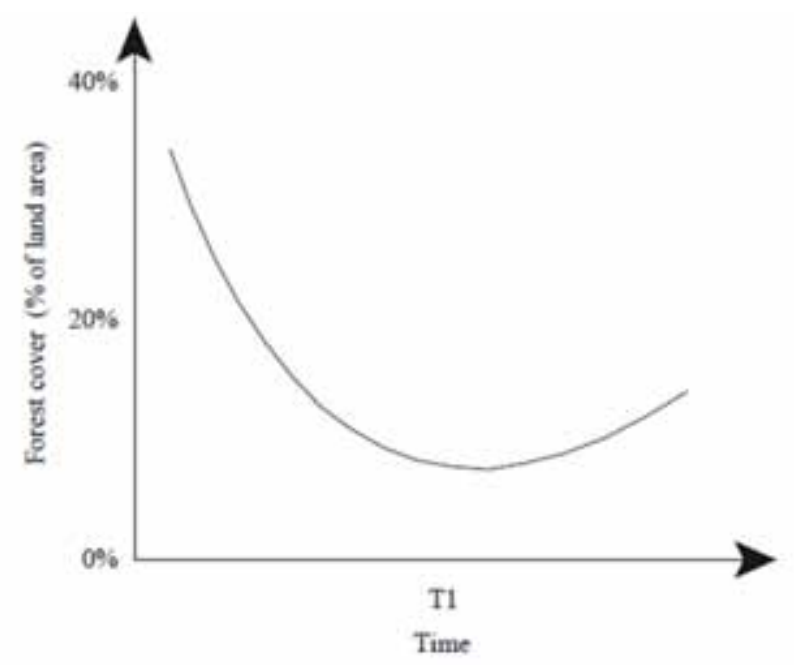

Source: Rudel et al. 2005, page 26.

A critique of this theory is that it opens the door to a laisse-faire policy, where governments do not have to create policies to preserve the environment because eventually forest growth will rebound in any event. ${ }^{7}$ But we should be cautious in taking this critique too far: to the extent

\footnotetext{
${ }^{7}$ Ryan, O’Donoghue, and Upton (2014) found in their paper entitled "Land use change from agriculture to forestry: a structural model of the income and leisure choices of farmers" that farmers are not even reacting to generous subsidies when considering agriculture versus forest choices. They state in their paper, "we observe a cohort of farmers who do not plant forestry regardless of income derived, reflecting their preference to maintain the flexibility of the long-term value of their land by continuing to farm."
} 
that urbanization itself depends on government action that can spur or discourage migration to cities, policies still matter.

In summary, the two theories outlined here view market signals as essential in both expanding and constraining deforestation, but in the end, they raise, rather than settle, the question of what role environmental policies play in reducing deforestation. The von Thünen theory, as further developed by Angelson, presents a world where the benefits of economic development technological innovation, infrastructure improvements, credit access, and so forth - may threaten forests in the absence of government interventions, since development could maintain or increase the profitability of converting forests into agricultural land. Those interventions may be necessary to capture the value of public goods provided by forests (whether their benefits are local or even global in nature). As a practical matter, we must still tease out the magnitude of those interventions' effects.

By contrast, forest transition theory initially seems more hopeful, with economic development proving conducive urbanization, which in turn promotes forest preservation. Here, forest policies do not have to be spelled out because they are, in the final analysis, of limited relevance. At the same time, forest transition theory will be less reassuring to those who lack confidence in urbanization's ability to lessen deforestation by itself, or to do so rapidly enough. The theory will also offer little comfort to those who believe that there may be ethical imperatives calling for forest policies that proactively counter deforestation and accelerate trends that preserve forest lands wherever possible. In other words, if policies can aid the reduction of deforestation, they may be warranted even if forests are already transitioning in an environmentally beneficial direction. And as with the von Thünen theory, we are left with the task of understanding if those policies are effective. That is what this dissertation sets out to do. In addition to modeling the impact of selected environmental policies, I also carry out field research to uncover the effects of one policy in particular, indigenous land rights. I find that certain environmental policies can be effective in reducing deforestation, though by themselves they are not sufficient to explain reduced deforestation in the Brazilian Amazon. And in those cases where an impact has yet to be demonstrated - this applies namely to land rights for indigenous people - policies can still produce positive outcomes for individuals, which may, in the longer term, be consistent with reducing stress on forests. 


\subsubsection{Rapid Decline in Deforestation in Brazil}

From the 1950s onward, Brazil had a strategy for economic development that incentivized people living in urban areas in the south to move north into the Brazilian Amazon and to make a living by felling trees, ranching cattle, and planting corn, soya beans, and other cash crops. As a result, Brazil experienced dramatic rates of deforestation, reaching a peak in 2004 (see Figure 4). The so-called deforestation belt involving the states of Mato Grosso, Pará, and Rondônia, shows how farming and settlements largely destroyed the native forest in the Amazon.

The 2008/09 financial crisis hit Brazil less dramatically than other countries. However, recently, economic growth statistics show a slowdown of the economy. Today, the country is ranked 79th on UNDP's human development index with a value of 0.754 compared to rank 63 and value 0.804 in 1995 . Brazil is thus part of the list of countries with a high human development.

Brazil has a total surface of 8.4 million square kilometers, of which 5 million square kilometers (or 60 percent of the total land area) cover the Legal Amazon ${ }^{8}$ region relevant for forest protection. This is the world's largest stretch of tropical forest. Only 12 percent of Brazil's population of 207 million live in the Legal Amazon (CIA Factbook). Brazil's census bureau divides the area into five regions, of which the Northern region covers most of the Legal Amazon.

Deforestation in the Brazilian Amazon has declined dramatically over the past decade (see Figure 4). Whereas the deforestation amounted to 29,059 square kilometers in 1995, it declined to only 6,207 square kilometers in 2015, a 79 percent decrease. In 2009, the Brazilian government committed to reducing deforestation by 80 percent by the year 2020 in relation to the 1996 to 2005 deforestation average. ${ }^{9}$ According to this measure, Brazil reached a 68 percent decline by 2015, an impressive achievement, with the fall in deforestation most dramatic after 2004.

\footnotetext{
${ }^{8}$ The Legal Amazon includes the Brazilian states of Acre, Amapá, Amazonas, Pará, Rondônia, Roraima, and parts of Maranhão, Mato Grosso, and Tocantins.

9 “The Brazilian government made a commitment in 2009 to reduce deforestation in the Amazon by 80 percent by the year 2020, in relation to the average between 1996 and 2005." Retrieved on November 22, 2016, from: http://www.bbc.com/news/world-latin-america-24950487.
} 
Figure 4. Annual area deforested $\left(\mathrm{km}^{2}\right)$ in the Brazilian Amazon, 1995-2015

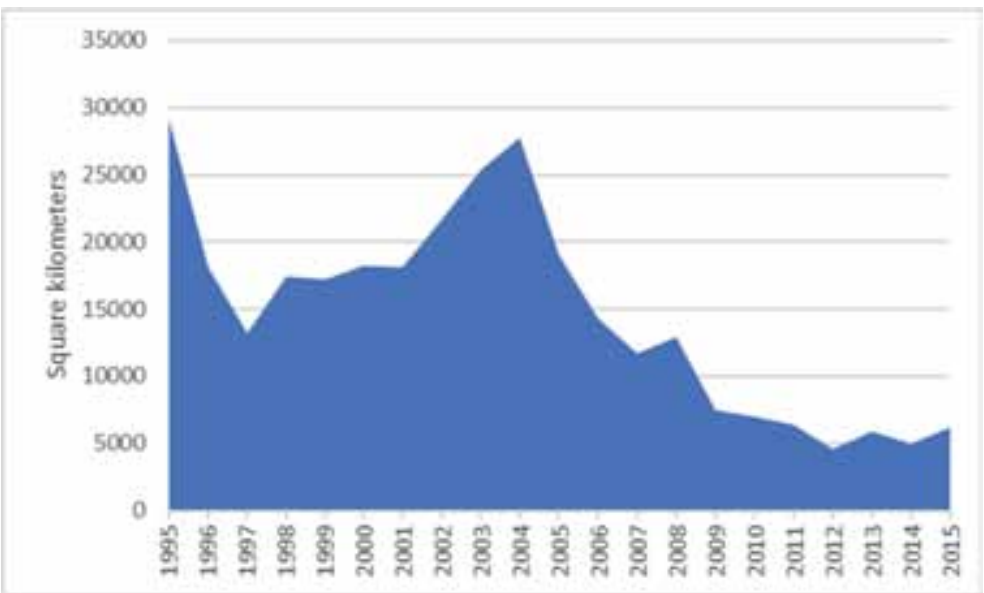

Source: Retrieved on November 22, 2017, from: http://www.obt.inpe.br/prodes/prodes_1988_2015n.htm

Figure 5 shows that while the deforestation rate has been declining, the estimated remaining forest cover in the Brazilian Amazon has recently leveled off at around 3.4 million square kilometers, which mirrors the dramatic decline in deforestation in the post-2004 period.

Figure 5. Estimated remaining forest cover in the Brazilian Amazon $\left(\mathrm{km}^{2}\right), 1995-2015$

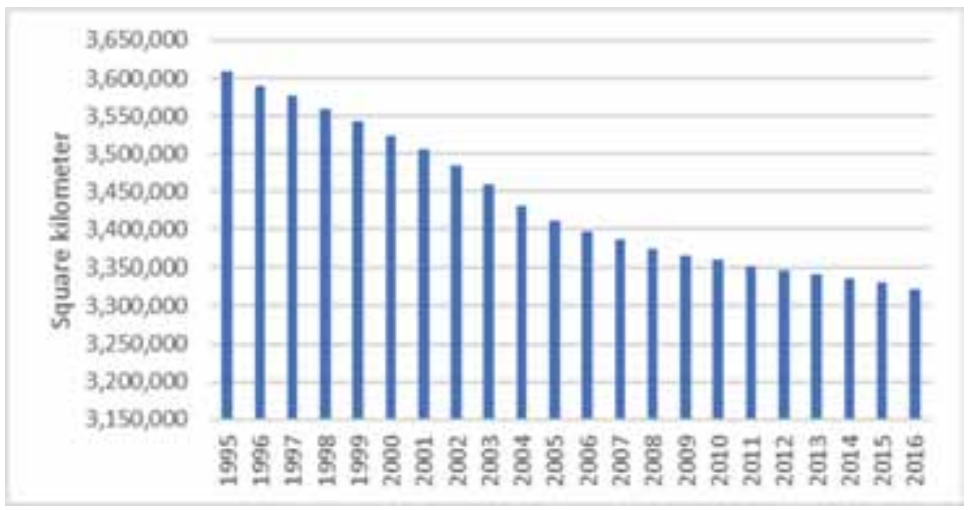

Source: https://rainforests.mongabay.com/amazon/deforestation_calculations.html

The decline in deforestation in the Brazilian Amazon over the 1995-2015 period is all the more impressive because Brazil achieved this decline while growing by an average GDP rate of 3.1 percent, and poverty rates (defined as the percent of the population living below USD1.90 per day) declined from an average of 13 percent of the population between 1996 and 2005 to an 
average of 6 percent of the population between 2006 and 2016 (World Bank data). Figure 6 overlays Figure 4 with the economic growth rate for the whole of Brazil. It shows that while Brazil developed economically, deforestation declined.

Figure 6. Annual area deforested $\left(\mathrm{km}^{2}\right)$ in the Brazilian Amazon, 1995-2015, and GDP growth rate for Brazil

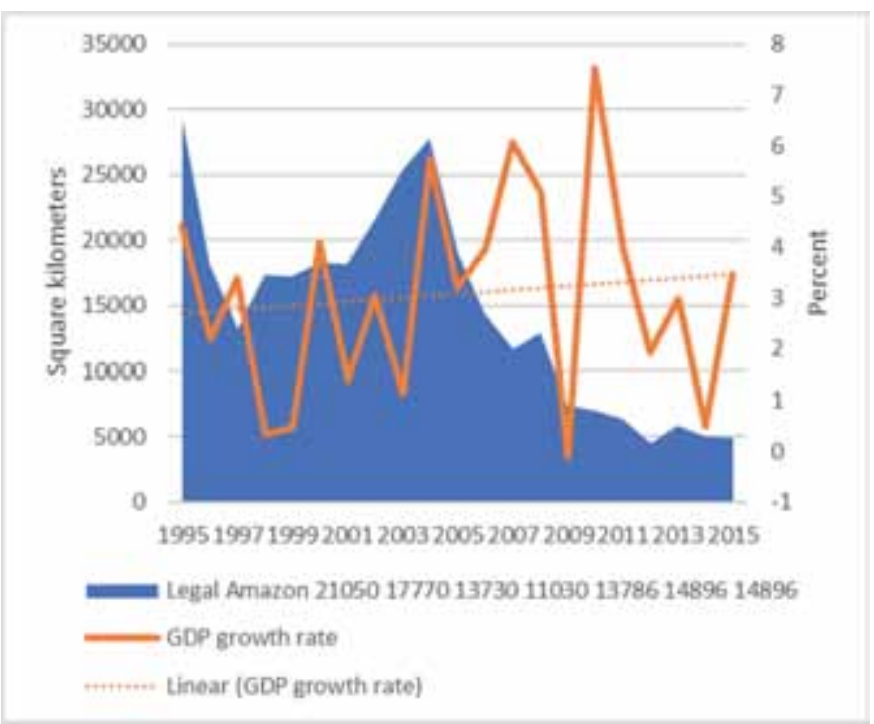

Source: Retrieved on November 22, 2017, from: http://www.obt.inpe.br/prodes/prodes_1988_2015n.htm and World Bank data.

As deforestation declined, so did population growth, though the link between the two is unclear. Brazil's population grew by 1.6 percent annually between 1991 and 2000 and slowed to 1.2 percent annually between 2000 and 2010 (see Figure 7). Urban areas saw an annual growth rate of 2.5 percent between 1991 and 2000 and a slowdown to 1.6 percent between 2000 and 2010. Rural areas saw negative growth of -1.3 between 1991 and 2000 and -0.7 between 2000 and 2010 (see Table 10).

Meanwhile, population growth in Brazil's Northern region, mostly covered by the Amazon, decreased from 2.9 percent annually during the $1991-2000$ period to 2.1 percent annually ${ }^{10}$

\footnotetext{
${ }^{10} \mathrm{I}$ based the annual population growth calculations using IBGE data presented in Figure 6 and used the following tool to calculate population growth retrieved on August 13, 2018, from: http://www.endmemo.com/algebra/populationgrowth.php.
} 
during the 2000-2010 period, according to population data of Brazil's Institute of Geography and Statistics (Instituto Brasileiro de Geografia e Estatística, IBGE).

Figure 7. Population growth in northern Brazil (Rondônia, Acre, Amazonas, Roraima, Pará, Amapá, Tocantins states) compared with Brazil, 1980-2010

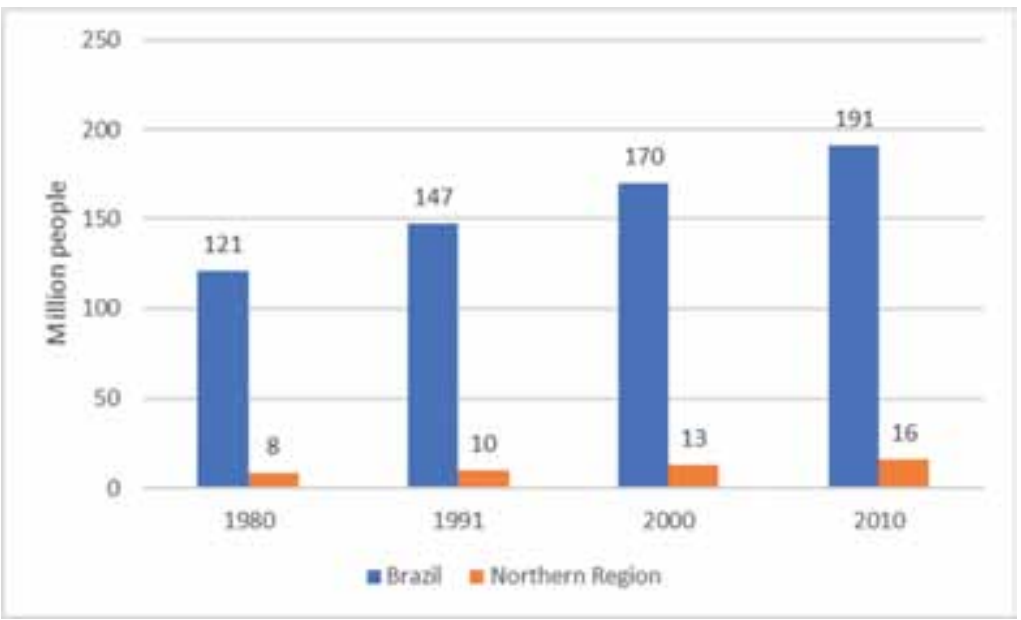

Source: https://censo2010.ibge.gov.br/sinopse/index.php?dados $=4 \& u f=00$

Under forest transition theory, one might expect a much more pronounced population shift from northern Brazil to urban areas in order to account for the declines in deforestation that Brazil witnesses. As for the von Thünen theory, the country's solid economic growth would have seemed favorable for agricultural rents and the further conversion of forests into farmland, not the stabilization of forest coverage. In other words, neither theory leaves us with easy explanations for Brazil's dramatic slowdown in deforestation of the Amazon.

\subsubsection{Brazil Commits to Deforestation Agreements}

Given Brazil's large tropical forests, environmental protection is important for Brazil and the world. The worldwide environmental movement of the 1980s culminated in 1993 in the Rio Conference. Here world leaders decided to help Brazil preserve the rainforest by funding programs such as the Pilot Programme to Conserve the Brazilian Rainforest (PPG7), to which the G-7 countries, the European Commission, and the Netherlands initially pledged some USD250 million. Other important milestones and international instruments that were created to preserve forests was the Non-Legally Binding Instrument on All Types of Forests (NLBI) 
and a Multi-Year Programme of Work agreed in 2007 in the framework of UN Forum on Forests and adopted by the United Nations General Assembly. ${ }^{11}$ It is the first international instrument of its kind for sustainable forest management. ${ }^{12}$

Furthermore, in the preparation that led to the Paris Conference on Climate Change, Brazil submitted its Intended Nationally Determined Contribution (INDC) to the Secretariat of the United Nations Framework Convention on Climate Change. ${ }^{13}$ Brazil's relevant policies, as documented in the INDC, are the National Policy on Climate Change (Law 12,187/2009), the Law on the Protection of Native Forests (Law 12,651/2012, called Forest Code), and the Law on the National System of Conservation Units (Law 9,985/2000). ${ }^{14}$

In its INDC, Brazil committed to (1) "strengthening and enforcing the implementation of the Forest Code"; (2) achieving zero illegal deforestation by 2030 in the Brazilian Amazon; and (3) "reforesting 12 million hectares of forests by 2030 enhancing sustainable native forest management systems, through georeferencing and tracking systems applicable to native forest management, with a view to curbing illegal and unsustainable practices." 15

\subsubsection{Providing Indigenous Communities with Land Rights as a Way to Protect Forests}

Since the Rio Conference in 1993, the Brazilian government and international donors have funded and implemented several projects aimed at protecting the Amazon rainforest. One of these is the Indigenous Lands Project that will be examined closer in chapters two and three of this thesis. Another is the Amazon Region Protected Areas (ARPA) project that established strictly protected areas in Brazil.

\footnotetext{
${ }^{11}$ Retrieved on December 8, 2017, from: http://www.undocs.org/A/res/62/98 and http://www.un.org/apps/news/story.asp?NewsID=22389.

12 Retrieved on December 8, 2017, from:https://www.un.org/apps/news/story.asp?NewsID=22389\#.WirEhUqnFPZ.

${ }^{13}$ Retrieved on December 8, 2017, from: http://www4.unfccc.int/submissions/INDC/Published\%20Documents/Brazil/1/BRAZIL\%20iNDC\%20english\% 20FINAL.pdf.

${ }^{14}$ Retrieved on December 8, 2017, from; http://www4.unfccc.int/submissions/INDC/Published\%20Documents/Brazil/1/BRAZIL\%20iNDC\%20english\% 20FINAL.pdf.

${ }^{15}$ Retrieved on December 8, 2017, from: http://www4.unfecc.int/submissions/INDC/Published\%20Documents/Brazil/1/BRAZIL\%20iNDC\%20english\% 20FINAL.pdf.
} 
The Indigenous Lands Project needs to be placed in the context of Brazil's latest national policy for environmental and land management in indigenous territories (Política Nacional de Gestão Ambiental e Territorial de Terras Indígenas, PNGATI), which was adopted in 2012. According to this policy, Brazil set a goal to protect natural resources in indigenous territories. However, conflicting tendencies with respect to this strategy exist within the Brazilian government and congress, such as the Brazilian growth acceleration program (Programa de Aceleração do Crescimento, PAC), and legislative changes, which aim at greater economic use of these resources by non-indigenous players.

With respect to the human rights of indigenous peoples, the international community and Brazil have come a long way. In 1989, the International Labor Organization (ILO) adopted Convention No. 169 Concerning Indigenous and Tribal Peoples in Independent Countries. Under Article 14, the Convention recognizes "the rights of ownership and possession of the peoples concerned over the lands which they traditionally occupy." ${ }^{16}$ Subsequently, this ILO Convention was referred to at the regional level, by the Inter-American Court of Human Rights in the Court's Nicaraguan Awas Tingni judgment of 2001, which "affirmed the existence of an indigenous people's collective right to its land" (Wiessner 2009 p. 6).

The latest achievement at the international level was the UN Declaration on the Rights of Indigenous Peoples, which was adopted by the UN General Assembly in 2007. This Declaration stipulates: "Indigenous peoples have the right to the lands, territories and resources which they have traditionally owned, occupied or otherwise used or acquired."17

Roque Roldán Ortiga from the World Bank compared different Latin American countries with respect to their stands on indigenous rights. In his 2004 review of Models for Recognizing Indigenous Land Rights in Latin America, Ortiga (2004) classified Brazil with its 1988 Constitution as having a superior legal framework jointly with Bolivia, ${ }^{18}$ Colombia, ${ }^{19}$ Costa

\footnotetext{
${ }^{16}$ ILO Convention 169 of June 27, 1989: Convention Concerning Indigenous and Tribal Peoples in Independent Countries. Retrieved on 08/02/2015 from:

http://www.ilo.org/dyn/normlex/en/f?p=1000:11300:0::NO:11300:P11300_INSTRUMENT_ID:312314.

${ }^{17}$ http://www.un.org/esa/socdev/unpfii/documents/DRIPS_en.pdf.

18 Thirty-six recognized indigenous groups live in Bolivia, counting about 10.4 million people and comprising 63 percent of Bolivia's population.

${ }^{19}$ Around 1.5 million indigenous people live in Columbia, comprising 3.5 percent of the population.
} 
Rica, ${ }^{20}$ Panama, ${ }^{21}$ Paraguay, ${ }^{22}$ and Peru. ${ }^{23}$ while other countries in the region have been classified as "in progress" or pertaining a "deficient legal framework" (Ortiga 2004, p. 3).

Caught between the government policies on settlements and conservation are the people who strive to escape poverty in Brazil's south by moving into the natural forest of the Amazon, and by indigenous people, rubber tappers, and rural farmers who have lived in the forest for centuries by pursuing sustainable cultivation methods and preserving natural resources. The arrival of the Europeans in the $16^{\text {th }}$ century led to the near extinction of the indigenous people in the Amazon. The military regime tried to assimilate the remaining indigenous peoples until the 1988 Constitution redressed the grievances of the indigenous people trying to right some of the wrongs from the past. The constitution provides for indigenous community land-use rights and guarantees community land rights and the obligation to demarcate and protect them.

\subsection{GAPS IN THE CURRENT RESEARCH LITERATURE ON DEFORESTATION IN BRAZIL}

In this section, two strains of literature are considered, one focuses on economic factors and the other looks at forest conservation policies. Those literatures are described and discussed in terms of concepts used, the causal structures on which they rely, and methods used for analyzing causal relations. Where they are based on theories, those theories are also described. The focus is on literature that uses geo-spatially explicit statistical models because such models are appropriate to capture deforestation in the Brazilian Amazon. The contributions my research will make to the existing literatures are also highlighted.

Over the past 25 years, many authors have assessed drivers of deforestation in the Amazon, often using geospatial modeling (Nazmi 1991, Barbier and Burgess 1996, Panayotou and Sungsuwan 1994, Andersen et al. 2002, Angelsen and Kaimowitz 1999, Geist and Lambin 2001). Some emphasize economic factors in deforestation, such as market prices for

\footnotetext{
${ }^{20}$ Eight indigenous peoples live in Costa Rica with a total population of 104,143 people, comprising about 2.4 percent of the national population.

${ }^{21}$ Panama is home to about 300,000 indigenous people, comprising 12.3 percent of the overall population.

22 Paraguay is home to about 112,848 indigenous people, comprising 1.7 percent of the population. However, 95 percent of the population identifies as indigenous.

${ }^{23}$ Peru is home to some 13.2 million indigenous people, comprising 45 percent of its population.
} 
agricultural commodities (Assunção et al. 2015, Boucher et al. 2013), while others look at forest policies.

Most recent studies have attributed Brazil's decline in deforestation mostly to economic drivers of deforestation, such as high beef and soy prices (Soares-Filho et al. 2006, Kirby et al. 2006, Nepstad et al. 2006, Pfaff et al. 2007, Nepstad et al. 2009, McAlpine et al. 2009, Barona et al. 2010, Macedo et al. 2012, Richards et al. 2012, Hargrave \& Kis-Katos 2013, Assunção et al. 2015). Some authors have focused on the influence of individual environmental policies, such as protected areas or enforcement and prosecution, for example (Soares-Filho et al. 2010; Sims 2010; Pfaff et al. 2015; Assunção et al. 2013, 2014, and 2015; Azevedo et al. 2014; Nepstad et al. 2014; Börner et al. 2015b; Cisneros et al. 2015; Gibbs et al. 2015; Hargrave \& Kis-Katos 2013; Rajão et al. 2012; Sills et al. 2015; Nolte et al. 2013; and Börner 2014 and 2015).

However, there is an important gap in the literature in understanding the marginal effect of Brazil's policy mix in explaining the deforestation decline.

\subsubsection{Literature on Drivers of Deforestation}

The literature describes three levels of drivers of deforestation. According to Angelsen (2010), the first level consists of agents or actors, the second level consists of intermediate causes, such as prices, markets, technologies, and geographical conditions, and the third level consists of underlying causes, such as international macroeconomic concerns and policy instruments. Angelsen (2010) developed a dual economic model consisting of the value in agricultural rent on the $\mathrm{y}$-axis and deforestation on the $\mathrm{x}$-axis (Figure 1 and Figure 2). He also brings private, local, and global forest benefits in the equation as forest rent (as opposed to agricultural rent). Angelsen (2010) uses an analytic economic modeling approach based on the von Thünen model described earlier.

Kaimowitz and Angelsen (1998) and Angelsen and Kaimowitz (1999) review more than 140 models of deforestation to determine its primary causes. In their theoretical framework, they distinguish between (1) immediate causes of deforestation, such as off-farm wages, credit availability etc., and land tenure security; and (2) underlying causes of deforestation, such as population growth, income level, and economic growth. Based on their analysis, causes of deforestation are tied to agricultural output prices, credit availability, technological change, accessible roads, and land tenure. Their findings on land tenure are inconclusive: depending on the location and land tenure policy, tenure security can encourage deforestation (farmers clear 
land to claim), or it can protect the environment. Although Angelsen and Kaimowitz do not use a modeling approach themselves, as would be the case in a rigorous meta-analysis using statistical methods and quantitative data only, they analyze existing models critically and compare analytical tools used. Chapter 4 of this dissertation will contribute to the literature on drivers of deforestation by using a comparison of effect sizes for different environmental policies in Brazil that influenced the decline in deforestation according to the authors.

Subsequently, Geist and Lambin 2001 undertook a comprehensive meta-analysis of 152 subnational case studies to determine factors that influence deforestation. They use a similar theoretical model as Angelsen and Kaimowitz 1999 of (1) proximate causes (intermediate causes according to Angelsen and Kaimowitz) and (2) underlying causes, as well as (3) a third category of other factors. According to Geist and Lambin (2001), proximate causes are agricultural expansion, wood extraction, and infrastructure extension (with 13 sub-categories). Underlying causes include: economic factors, policy and institutional factors, technological factors, cultural factors, and demographic factors. Other factors include land characteristics, biophysical drivers, and social trigger events, such as civil wars. The authors end up with a list of 118 sub-categories that have some relation to deforestation. They find that "policy and institutional factors - such as formal state policies, informal policies (policy climate), or land tenure arrangements - exert by far the strongest impact upon proximate causes [of deforestation]" (Geist and Lambin 2001, p. 57). I will return to this finding in chapters four and five of this dissertation.

Referring to the literature, Geist and Lambin (2001) observe that scholars either determine a single factor as the main driver of deforestation, or they identify a complex group of variables responsible for deforestation that cannot be further simplified. Geist and Lambin (2001, p. 2) themselves can be situated on the side of complexity when they conclude that "tropical deforestation is driven by identifiable regional variations of synergetic cause/driver combinations in which economic factors, institutions, national policies and remote influences are prominent." They continue: "Our findings reveal that too much emphasis has been given to population growth and shifting cultivation as primary and direct causative variables at the decadal time scale. I further show that region-specific patterns of causation can be identified in addition to the more 'robust' proximate and underlying causes (or cause connections) showing low regional variations, if subnational rather than countrywide evidence is taken" (p. 2). This latter finding is of interest since Armenteras et al. (2009) find that factors of deforestation are 
location-specific, and that "physical inaccessibility" is another factor explaining avoided deforestation.

Geist and Lambin (2001) analyzed 95 articles and identified 152 cases of tropical deforestation. Articles had to cover net loss of forest cover for at least two points in time and at subnational scale in Asia, Africa, and Latin America. The meta-analysis covers a mix of qualitative and quantitative articles and identifies deforestation narratives, qualitative interpretation of secondary data on deforestation, and quantitative empirical analysis of forest cover loss, using regression analysis, and other techniques. The meta-analysis identified the frequency of occurrence of proximate and underlying factors of deforestation. The effort of bridging the gap between qualitative and quantitative studies was a complex undertaking that sparked much follow-up research.

For example, following this major effort to identify 118 factors contributing to deforestation, Nolte et al. (2013a) specifically focus on the Brazilian Amazon for their analysis. They take the Rapid Assessment and Prioritization of Protected Area Management (RAPPAM) method used to self-assess protected areas and find that the lack of tenure security is the primary determining factor for deforestation. They "examine the relationship between RAPPAM scores and the success of protected areas in avoiding deforestation in the Brazilian Amazon" and find that "disputes regarding land tenure emerged as the one factor to be most consistently associated with the extent to which protected areas succeeded at avoiding deforestation" (Nolte et al. 2013a, p. 6). None of the other RAPPAM indicators, such as adequacy of budget, staff numbers, equipment, management plans, and stakeholder collaboration were consistently associated with avoided deforestation.

The finding of Nolte et al. (2013a) that insecure property rights are the main driver in Brazilian deforestation echoes other, earlier, research. For instance, Araújo et al. (2009) find for the Brazilian Amazon that insecure property rights drive deforestation. Prior to Araújo et al., (2009) van Gils et al. (2006, p. 81) find for neighboring Bolivia that "land tenure regime, distance from roads, and distance from settlements" were the main drivers of deforestation. Similarly, White and Martin (2002, p. 1) find that "forest degradation has steadily increased throughout much of the world. At the same time there is growing realization that insecure property rights are a key underlying problem and cause of degradation." This dissertation contributes to the literature by testing whether secure property rights make a difference in terms of forest preservation in one type of protected area, namely indigenous lands (chapter three). 
Even though the literature highlights insecure property right as a major cause of deforestation, strengthening property rights would not necessarily reduce deforestation. Depending on the local context, more secure property rights could make deforestation more profitable, while less secure property rights would make investments less profitable (Angelsen 2010). On the other hand, as is the case in Brazil, deforestation could be used as a strategy to establish ownership and a land title (Angelsen 2010). I will return to the discussion about land ownership, especially community land ownership, in chapter three of this dissertation.

\subsubsection{Literature on Forest Conservation}

As of 2017, there have not been many attempts in the literature to understand the recent dramatic decline in deforestation in the Brazilian Amazon.

In their 2015 paper "Deforestation Slowdown in the Legal Amazon: Prices or Policies?" Assunção et al. show the predicted deforestation trend between 2004 and 2009 and compare this predicted trend with the observed decline in deforestation (Figure 12). Their prediction shows that in the absence of environmental policies, deforestation would have been much higher (the orange line in Figure 8). Economic factors, such as prices for soy beans and beef, would have driven deforestation rates up, according to their estimates.

However, the real decline in deforestation was much more pronounced and can only be attributed to environmental policies (Assunção et al. 2015). The paper creates a proxy for policies that consists of the period the policy was issued, and tight land constraints. However, the paper does not spell out any specific policy interventions, such as protected areas, or enforcement actions. This is where my contribution seeks to fill a gap. I want to know to what extent particular environmental policies can be associated with a decrease in deforestation in the Brazilian Amazon. 
Figure 8. Half of the decline in deforestation can be explained by environmental policies and the other half by economic drivers of deforestation

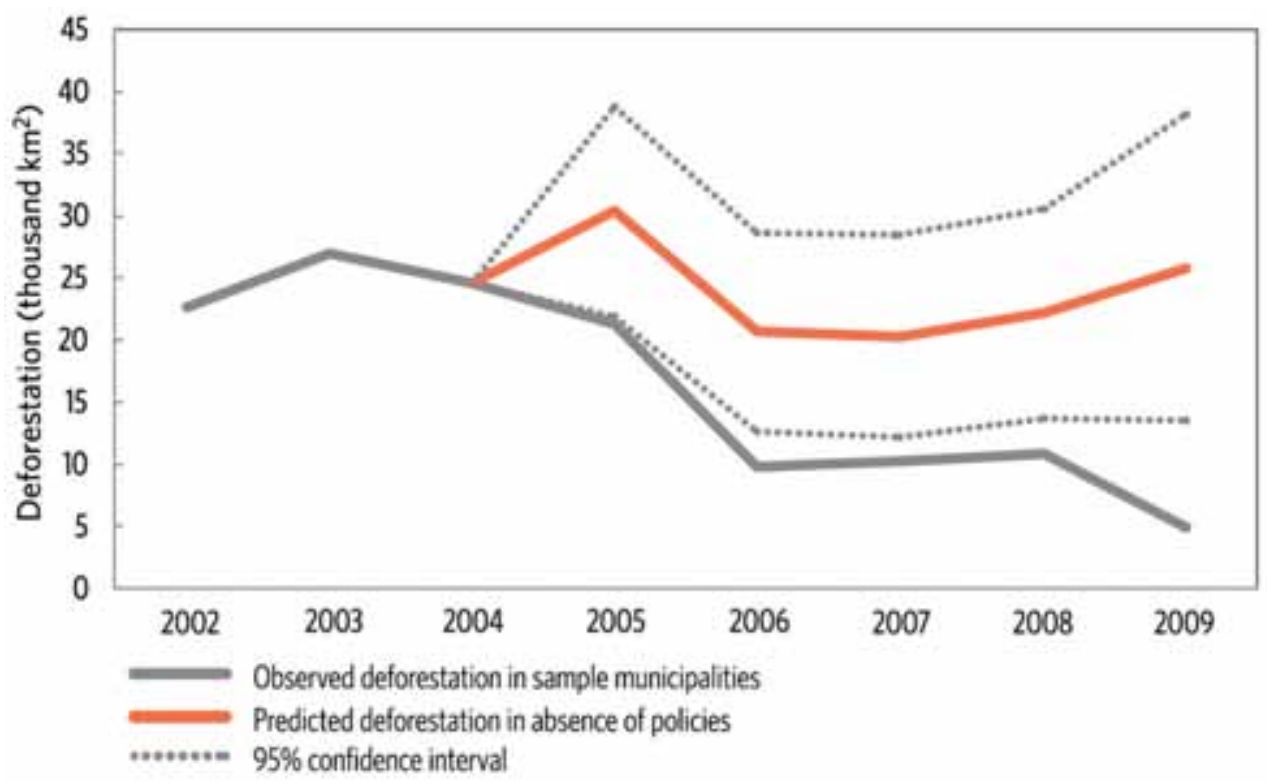

Source: Assunção et al. 2015.

Many researchers have already analyzed how individual policies affect deforestation outcomes (Assunção et al. 2013a, 2014, 2015; Azevedo et al. 2014; Börner et al. 2015; Cisneros et al. 2015; Gibbs et al. 2015; Hargrave and Kis-Katos 2013; Rajão et al. 2012; Sills et al. 2015; and Nolte et al. 2013). However, none of them compared the effect $\operatorname{sizes}^{24}$ of these different environmental policies. I use effect sizes to make the impact estimates from different papers comparable.

As highlighted by Assunção et al. (2015) and others (Nelson et al. 2001, Araújo et al. 2009, Robinson et al. 2014, and Lawry et al. 2014), land rights are a key factor in deforestation. Therefore, this dissertation will drill down on one policy, the policy on demarcating indigenous lands that provided indigenous communities with the rights to their lands. Why might improvements in land rights for indigenous communities affect the pace and extent of deforestation? Bohn and Deacon (2000) provide a theoretical framework through which weak land tenure rights affect the rate of forest harvesting (as well as use of other natural resources).

\footnotetext{
${ }^{24}$ The effect size is a standard measure to compare two means. "Effect size is defined as the estimated effect divided by the standard deviation of the outcome variable in the control group." (Cohen, J. 1988).
} 
In their model, less secure rights over standing forests lead unambiguously to faster forest harvesting, as risks of future risks diminish the discounted future value of the forests. Thus, communities may slow their own harvesting in response to their extended prospects.

Even more directly, if encroachment on these communities' lands is motivated by resource extraction, more secure rights reduce the likelihood of expropriation and thus deforestation by encroachers. Araújo et al. (2009) suggest that tenure insecurity may itself motivate encroachment and deforestation by squatters as a strategy to eventually gain formal title to land. Both mechanisms depend on the expropriation risk level: for sufficiently low risks, tenure rights themselves do not affect forest harvesting rates.

Consistent with both mechanisms, evidence from the broader literature largely finds positive impacts of land rights improvements on deforestation. Robinson et al. (2014) conduct a metaanalysis of 118 sites covered by 36 papers in this literature (largely in non-indigenous contexts) that plausibly control for potential confounds and find generally positive effects. Most salient for our case, Araújo et al. (2009) find substantial deforestation reductions in Brazil associated with improved tenure security.

Similarly, Nelson et al. (2001) find slower deforestation in lands with greater protections in a remote province of Panama. More broadly, Lawry et al. (2014) provide a meta-analysis of land rights improvements on agricultural (rather than forested) lands and show gains in productivity, consistent with a more general theory of investment responses on better-secured lands. In the Brazilian Amazon itself, Alston et al. (1996) document similar agricultural responses to private titling.

These promising results from improvements in tenure security over non-indigenous lands coalesce with findings from the literature studying indigenous communities. As noted above, this literature has to date assessed indigenous control as a static set of rights (Nepstad et al. 2006, Nelson and Chomitz 2011, Nolte et al. 2013, Pfaff et al. 2014, and Vergara-Aseno and Potvin 2014). Using both global and within-country comparisons, these studies find that indigenous lands generally exhibit lower deforestation rates than those with other governance forms, be they privately owned, publicly owned but eligible for sustainable use, or publicly owned protected areas (controlling for other features that often differentiate these lands from indigenous ones). A notable exception is Buntaine, Hamilton, and Millones (2015), which find 
no impacts of the formalization of land rights in one region of Ecuador but whose external validity is limited.

Together with the literature studying indigenous communities, these results suggest that formalizing the land rights of indigenous communities may serve as a viable policy to conserve tropical forests. However, to date, no study has reliably assessed this claim on a large scale. Here I attempt to make another contribution to the literature. Using a completely novel dataset, I will answer the research question "What has been the effect of demarcating indigenous territories on forest preservation?" (research question No. 2).

Drilling further down to the individual indigenous communities, I seek to find out how formalizing of land rights and monitoring support lead to improvements in indigenous peoples' livelihoods and survival in demarcated indigenous territories. A review of the literature offers a surprise. After analyzing the near-disappearance of indigenous populations for decades, more recent scholarship noticed a turnaround and rapid population growth among indigenous communities (IBGE 2012, McSweeney et al. 2005).

The literature on indigenous communities has long focused on the traumatic near extinction experiences following the first contacts with the European explorers (Hemming 1978). Europeans did not reach South America until the mid-sixteenth century, although European diseases predated their arrival through indigenous trade routes.

Before the arrival of the Europeans, the indigenous population in Brazil was estimated at three to eight million (Lisansky 2005) compared with the nadir of 150,000 in the 1950s (Ramos 1984) and 240,000 in the 1990s at the beginning of the Indigenous Lands Project (World Bank 1995). In the early 1990s, approximately 145,000 indigenous people lived in the Amazon region (World Bank 1995). According to the 2010 census, Brazil counted 817,963 indigenous people (IBGE 2012).

The Brazilian Amazon has encountered several waves of settlements for extractions since the $16^{\text {th }}$ century, such as rubber extraction in the $18^{\text {th }}$ century, the occupation of Brazil's hinterlands (the so-called "Marcha para o Oeste") during and after the second World War, the construction of the Trans-Amazonian Highway in the 1950s, and finally national and multinational firms investing in agribusiness in the 1970s (Ramos 1984). All these settlement and extraction waves led to the near extinction of the indigenous peoples. More recently, however, articles have highlighted a "demographic turnaround" in indigenous populations in Latin America and 
particularly in Brazil (IBGE 2012, McSweeney et al. 2005). In Brazil, some of the resurgence of indigenous populations can be attributed to racial-ethnic reclassification, according to Perz et al. (2008), other factors are reduced morbidity, increased child survival, and improved health conditions (Perz et al. 2008).

According to Alexiades (2009), the literature on mobility, especially coming from ecologists and ethnobiologists suggested that indigenous cultures tended to be tied to specific locations. Historical records, however, point to a "long history of movements, exchanges, displacements and changes in the spatial" location among Amazonian societies (Alexiades 2009, p. 283). Formalization of land rights, as implemented by FUNAI and funded in part by the Indigenous Lands Project, provided indigenous communities with the right to their ancestral lands by also curtailing movements across wider areas.

Today, urbanization continues to attract rural people to the cities worldwide. This is also true for the Amazon as Padoch et al. (2008) found that about 70 percent of the population living in the Amazon basin is in cities. Skedon (1977) makes the distinction between circular migration, semi-permanent migration, and permanent migration and short and long-distance migration for villagers in Peru.

Various forms of migration are important for the indigenous people in the Amazon as well. What is new in the Amazon context is the way urban residents, whether indigenous or not, keep their ties with rural areas with respect to their networks, land use decisions, and multi-sited households. The concept of "rural, urban, and in between" mobility Padoch et al. (2008) describe best what I observed among indigenous people in the Brazilian Amazon.

As described above, in parallel to the dramatic decline in deforestation, Brazil has encountered not only continued economic growth but also a decline in poverty and gains in education and health status. These social aspects have been studied by a broad literature covering programs, such as Bolsa Escola and its successor Bolsa Família, both conditional cash transfer programs that transferred funds to mothers on the condition that they send their children to school and meet other nutrition and health requirements (Hall 2008, Glewwe et al. 2012, Soares et al. 2010, Rasella et al. 2013, Zucco et al. 2013, Guanais 2015, and De Brauw et al. 2015).

In summary, population growth, migration, and poverty alleviation have been covered by the literature and set the context. To my knowledge, however, no other literature has looked at how formalizing of land rights and monitoring support affected indigenous peoples' livelihoods and 
survival in demarcated indigenous territories. I will therefore answer the following subquestion in this dissertation: "How does formalizing of land rights and monitoring support lead to improvements in indigenous peoples' livelihoods and survival in demarcated indigenous territories?" (research question No. 1).

\subsubsection{Overarching Research Question and Sub-Questions}

Overarching research question: The overarching research question for this dissertation is, what are the factors that explain the rapid annual decline in deforestation in the Brazilian Amazon since 2004? To answer this question, the dissertation will approach the analysis through several sub-questions.

\section{Sub-questions:}

(1) How does formalizing of land rights and monitoring support lead to improvements in indigenous peoples' livelihoods and survival in demarcated indigenous territories?

(2) What has been the effect of demarcating indigenous territories on forest preservation?

(3) How do environmental policies compare with each other in terms of their effect sizes ${ }^{25}$ ?

(4) To what extent can environmental policies be associated with a decrease in deforestation in the Brazilian Amazon?

To answer these research-specific questions, I will use the methods and data described below.

\subsubsection{Methods and Data}

Following Bamberger et al. (2010), Woolcock (2013), and Andrews et al. (2017), I use a mixed methods approach for this dissertation. Below, I will discuss my research questions and the methods used to answer them.

To answer research question 1, I used case studies and field observations, as well as expert interviews, data from IBGE, Brazil's census bureau, and data published by the Brazilian NGO Instituto Socioambiental, to assess the impact of land demarcation and monitoring support on four indigenous communities in the Brazilian Amazon. In particular, I used case study data and

\footnotetext{
${ }^{25}$ The effect size is a standard measure to compare two means. "Effect size is defined as the estimated effect divided by the standard deviation of the outcome variable in the control group." (Cohen, J. 1988).
} 
observations from my field trip to four indigenous communities in the Brazilian Amazon and complement these data with evidence from the literature.

My research in chapter two is an effective introduction to chapter three, which assesses the impact of demarcation on forest preservation using quantitative methods. The qualitative part of the field research was part of an ex post evaluation mission for KfW Development Bank, which allowed me to enter indigenous territories for which access is highly restricted.

To answer research question 2, I used geospatial impact evaluation methods to compare the impact of demarcation on forest preservation in treatment and control groups using panel data analysis. This research used a novel, so far unexplored, dataset shared by Brazil's Indian Organization, FUNAI, through the KfW Development Bank.

This dataset has been developed during the implementation of the Indigenous Lands Project, funded jointly by KfW Development Bank and the World Bank. My research used remotely sensed satellite imagery covering 1982-2010 from the NASA Land Long-Term Data Record (LTDR) as well as the Normalized Difference Vegetation Index (NDVI), that captures biomass on the ground.

To answer research questions 3 , I conducted a systematic review of the literature resulting in six papers that met my selection criteria in terms of rigorous impact evaluation methods with treatment and control groups. I compared different effect sizes using the method developed by Samii et al. (2014) to compare the effectiveness of deforestation policies in curbing deforestation. Comparing effect sizes makes the impact estimates of different papers comparable.

Finally, to answer research question 4, I analyzed a complex panel dataset with geogeospatially explicit data, such as Programa de Cálculo do Desflorestamento da Amazônia (PRODES) deforestation data. I relied on a comprehensive dataset developed at the University of Bonn modeling and predicting deforestation outcomes in the Brazilian Amazon and which was developed by Jan Börner and Elias Cisneros. The panel dataset with variables that can be associated with deforestation and environmental policy variables served to estimate the marginal effectiveness of eight different environmental policies at reducing deforestation using fixed effects and first differences methods. 
In addition to the above-listed qualitative and quantitative methods, I explored two other methods, Qualitative Comparative Analysis (QCA) and Structural Equation Modeling (SEM). QCA is a method of quantifying qualitative research used to "produce comprehensive, ingenious explanations of social phenomena" (Legewie 2013). According to Rihoux and Ragin (2009, p. 14), in contrast to most statistical tools, QCA “opens a 'black box' of formalized analysis, by demanding from researchers not only that they make choices but also that they account for them." I planned to apply the approach to chapters two and five. As it turned out, my sample of case studies was too small in chapter two and my dataset in chapter five too complex for the use of QCA, which led me to abandon QCA for this dissertation.

SEM is a statistical technique that integrates several statistical approaches into one model, such as "measurement theory, factor (latent variable) analysis, path analysis, regression, and simultaneous equations interaction effects" (Sturgis 2018). SEM can be used to understand interaction effects of complex systems (Henseler 2010). In this respect, the method would be useful to apply to my complex model of eight different environmental policies in Brazil that overlap on the ground. ${ }^{26}$

According to Wong $(2013$, p. 1), "there are two sub-models in a structural equation model; the inner model specifies the relationships between the independent and dependent latent variables, whereas the outer model specifies the relationships between the latent variables and their observed indicators." Accordingly, SEM allows one to determine causal pathways for different samples, given that mechanisms of change are context-specific.

If policy effects depend on other policies, the cumulative effect differs from the sum of partial effects. In general, combined effects will be different. SEM allows the researcher to analyze policy interaction effects, and to critically evaluate the results from other studies. The presence

\footnotetext{
${ }^{26}$ According to Blohmke, Kemp, and Türkeli (2016), SEM is a "multivariate data analysis, which is based on a theoretical model involving unobservable latent variables and a measurement model [...]. SEM allows the researcher to investigate different model structures. SEM include usually two types of sub-models: the inner and the outer model [...]. SEM allow researchers to include unobservable variables, which are measured indirectly by indicator variables [...]. The inner model describes the relationship between independent and dependent latent variables $[\ldots]$. Latent variables cannot be observed directly. The outer model, also known as measurement model, specifies the relationship between observed indicators and latent variables."
} 
of policy interaction effects can also be studied through interviews with experts and people subjected to policies.

In the thesis, the interaction effects of determinants (contingent, synergetic, opposed) are poorly considered as is often the case in econometric analysis. I had hoped that my knowledge of the topic of investigation (based on direct observation and discussions with stakeholders and local experts) would have allowed me to identify relevant causal pathways and test them.

However, as it turned out, another researcher used the same complex dataset I used in chapter five applying SEM. However, he met difficulties given that data to specify variables were not available and had to be replaced by assumptions that made the outcome less meaningful as expected. For this reason, and because my interviews did not yield the required information either, I decided to not use SEM in chapter five, but to apply a more traditional statistical approach.

The overall hypothesis for this dissertation is that environmental policies do play a role in the decline in deforestation and that demarcated indigenous territories can be an effective means to preserve the Amazon rainforest, while also allowing indigenous people to prosper.

\subsection{MY CONTRIBUTION TO THE LITERATURE}

The original contribution of this dissertation to these streams of literature is as follows: visiting indigenous communities in the Amazon is an opportunity that only few people experience due to restrictions in access designed to protect those communities. As a staff member of KfW Development Bank, I had the privilege to evaluate the KfW and World Bank-funded Indigenous Lands Project and gain first-hand experience and observations of the conditions under which indigenous communities in the state of Amazonas live. The case studies of the four indigenous communities are thus an original addition to the literature (research question 1).

To answer the second research question, I relied on a completely novel dataset, which required interviewing staff, going through FUNAI's archives, and tracking down former FUNAI staff. This database includes detailed demarcation dates (months and years) for 151 indigenous communities, which made it possible to compare demarcated with not yet demarcated 
indigenous communities within a rigorous impact evaluation, something that has never been done before.

To answer research question 3, I followed the example of Samii et al. (2014), as adapted by Börner et al. (2016) and applied that approach to Brazil, covering the available literature that uses treatment and comparison groups to estimate the effect of an environmental policy on forest preservation.

Finally, to answer research question 4, I combined eight environmental policies in one model predicting deforestation and estimated the marginal effect of these policies on forest preservation to better understand the sudden decline in deforestation in the Brazilian Amazon forest. While other authors have examined one or two policies, no other researchers have included eight environmental policies in one model and estimated the marginal effect on deforestation. Thus, this is an original contribution to the literature.

\subsection{Publication And Dissemination}

This research has in part been published and disseminated. It is based on an ex post evaluation I conducted for the KfW Development Bank in Frankfurt. The fieldwork involved a field trip to Brazil. An evaluation report was sent to the German Federal Ministry for Economic Cooperation and Development (BMZ) and a short version is published on KfW's website (https://www.kfw-entwicklungsbank.de/PDF/Evaluierung/Ergebnisse-undPublikationen/PDF-Dokumente-A-D_EN/Brasilien_Indianergebieten 2013 E.pdf).

The academic research in chapters two and three is based on this evaluation. As a follow-up to the ex post evaluation, KfW's evaluation department partnered with AidData from the College of William and Mary in Williamsburg, Virginia. This cooperation led to a joint paper that I coauthored with AidData. The resultant article was published in the peer-reviewed Journal of Environmental Economics and Management in July 2017.

I presented the paper during the 18th Annual BIOECON Conference entitled "Instruments and Incentive Mechanisms for Biodiversity Conservation and Ecosystem Service Provision," September 14-16, 2016, at Kings College, Cambridge, U.K., and received valuable feedback. In November 2017, I was asked to submit a chapter on the "Effectiveness of forest protection policies in the Brazilian Amazon" as part of a Springer book on "Strategies for forest 
conservation in South America," edited by Felix Fuder. This chapter is part of this dissertation. An extended version of chapter five may be published later.

\subsection{ORganiZATION OF THE THESIS}

This dissertation is organized into six chapters. Chapter two introduces the case study background, including a detailed description of the theoretical framework and the methods used and presents the case study analysis answering research question 1. Chapter three examines the effect of demarcating indigenous territories on forest preservation and answers research question 2. Chapter four compares the effect sizes of different environmental policies in the Brazilian Amazon as found by other authors in the literature and answers research question 3. Chapter five combines proxy variables for eight different environmental policies in one model to better understand the decline in deforestation in the Brazilian Amazon and the marginal effect these policies may have. In chapter six, I draw conclusions and discuss the policy relevance of my findings. 


\section{INDIGENOUS PEOPLES, LAND DEMARCATION, AND ENFORCEMENT}

\subsection{INTRODUCTION}

The first chapter introduced the theoretical models associated with deforestation and the dramatic decline in deforestation in the Brazilian Amazon between 2004 and 2012. The von Thünen theory is relevant to this chapter. One of the environmental policies that may have contributed to the decline was a shift in the engagement with indigenous territories, which cover about 20 percent of the Brazilian Amazon.

About half of this area has been demarcated under the Indigenous Lands Project (implemented by FUNAI, Brazil's indigenous peoples' organization, and funded by KfW Development Bank and the World Bank's Rainforest Trust Fund). The project funded land demarcation and the provision of indigenous community land titles, as well as monitoring and enforcement support. This chapter will present this project as an introduction to chapter three based on four case studies.

Administratively, Brazil has 26 states, 9 of which are in the Legal Amazon. The lowest administrative unit is the municipality. There are 5,507 municipalities countrywide, 756 of which are in the Legal Amazon. The arc of deforestation stretches around the southern end of the Legal Amazon, including the states of Pará, Rondônia, and Mato Grosso. Inside the Brazilian Amazon there are vast stretches of protected area, covering about 40 percent of the Legal Amazon. Some areas are strictly protected, and others allow sustainable use of the forested area, among them indigenous territories. According to FUNAI, 435 indigenous territories have finalized their demarcation process and received their community land title, while 114 still have to be studied and demarcated (FUNAI 2017), where demarcation means the act of creating a boundary around a place.

The respected Brazilian NGO Instituto Socioambiental (ISA) has a different count, according to which there are 706 indigenous territories in Brazil, of which 480 have been demarcated and received their community land title. Indigenous peoples have community land titles to these lands with large differences in size. The unit of analysis for this thesis will be either indigenous territory (also referred to as indigenous lands), or the municipality within the Brazilian Legal 
Amazon region (which overlaps mostly with Brazil's Northern administrative region and consists of nine states).

Indigenous people are 0.4 percent of Brazil's population and they use and protect more the 20 percent of the Amazon forest. Starting in the 1950s, the government of Brazil promoted policies to encourage Brazilians to settle in the Amazon, clearing forest to ranch cattle and plant cash crops. These settlements often posed a threat to the survival of the indigenous peoples, a matter addressed in Brazil's 1988 Constitution, which guaranteed the demarcation and a community land title for indigenous communities in Brazil.

Aaccording to Hargrave (2013, p. 457): "Because of incomplete property rights regulation, large parts of the Brazilian Amazon forest can be still considered as open access. Since the establishment of the land statute of 1964 (which served as a basis for land reform) settlers are allowed to use undeveloped land which can become private property after ten (later five) years of continuous use" (cf. Araújo et al. 2009).

The literature broadly agrees that providing indigenous peoples with the rights to their land will improve their cultural autonomy. However, there is less evidence that a life in these territories will lead to improvements in indigenous peoples' livelihoods, given that these territories are remote and difficult to reach.

Sunderlin (2008) conducted a spatial analysis to assess the association between poverty and forests in seven countries (Brazil, Honduras, Malawi, Mozambique, Uganda, Indonesia, and Vietnam) and found a positive correlation between poverty rates and densely forested areas. According to the results, "for most of these countries, there was a significant positive correlation between high natural forest cover and high poverty rate (the percentage of the population that is poor) and between high forest cover and low poverty density (the number of poor per unit area)" (Sunderlin 2008, p. 23). In Brazil, this is reflected in the IBGE census and it was also evident during my field visit. As I will show below, poverty rates are comparatively high in indigenous territories as compared with the rest of Brazil.

Living in an indigenous territory may involve forgoing access to the kind of modern amenities typically associated with development. Development may involve access to a quality education, higher income, improved health services, and political participation. This chapter will explore whether such a trade-off exists among the indigenous communities in the Brazilian Amazon. 
The research question for this section is "How does formalizing land rights and monitoring support improve indigenous peoples' livelihoods and survival in demarcated indigenous territories as originally intended by the Indigenous Lands Project?" In other words, are indigenous land rights a blessing or a curse for the indigenous communities? I will explore this question using qualitative case study methodologies. This rather descriptive chapter also serves as an introduction to chapter three, where the effect of land title on forest preservation will be examined. Based on case studies of four indigenous territories, I will explore:

(1) Whether demarcation and enforcement took place

(2) Where indigenous peoples draw their livelihood

(3) How basic services are provided

(4) Whether indigenous peoples actually live in indigenous territories.

The Indigenous Lands Project was funded jointly by KfW Development Bank and the Rainforest Trust Fund of the World Bank. The project was designed to secure the survival of indigenous communities in demarcated territories, to preserve forests, and to increase the wellbeing of indigenous people. According to the Memorandum and Recommendations of the Director of the Latin America and the Caribbean Department: "The general objective of the proposed project is to improve the conservation of natural resources in indigenous areas and increase the well-being of indigenous people through: (i) regularization of indigenous lands in the Legal Amazon; and (ii) improved protection of indigenous populations and areas" (World Bank 1995, Project ID: P006567, TF-21953). The project would be considered successful if the number of indigenous people in indigenous territories increased.

The land demarcation process consisted of putting up panels and landmarks at critical intersections of roads and waterways and mapping indigenous lands via global position system technology (GPS). Formalization of land rights included a signature by Brazil's president, as well as registration in Brazil's official registry. Demarcation and formalization were crucial steps for land rights security. However, on a day-to-day basis, the additional support stipulated by Brazil's 1988 Constitution and financed under the Indigenous Lands Project was enforcement. Support for patrolling the area and self-organization into indigenous organizations with political influence helped in protecting indigenous lands to some extent.

In addition, contact with the National Indian Foundation (Fundação Nacional do Índio, FUNAI), forest police, and Brazilian Institute of the Environment and Renewable Natural 
Resources (IBAMA), contributed to making indigenous lands more secure for the indigenous people. However, multiple resource conflicts exist and patrolling the area continues only in those territories where FUNAI continues to provide financing.

\subsubsection{Results Framework for Exploring Links Between Demarcation and Monitoring Support and Livelihoods Opportunities and the Survival of Indigenous Peoples}

Below, I will explain the intervention logic behind the project leading from input to output, via outcome to impact. Another term for the intervention logic is 'results framework.' According to the World Bank's Independent Evaluation Group, “A results framework is [...] a useful management tool, with program implementation assessed in direct relationship to progress in achieving results, at the outputs, outcomes, and impact levels. It helps achieve strategic objectives. The strategic objective is the ultimate driver of a program" (IEG 2012, p. 10). The literature also refers to the term 'program theory' (Rossi et al. 1999), but I will be using the term 'results framework' so as to differentiate it from social science theory.

Fundamentally, I can think of the Indigenous Lands Project as providing support (inputs) for formalizing indigenous land rights and for securing the borders. This leads to communities receiving community land titles and secured borders (outputs). The use of the land for fishing, hunting, gathering, and shifting cultivation provides indigenous communities with livelihood opportunities under the assumption that no resource conflicts exist with neighboring communities or adjacent farmers (outcome). The impact is high population growth among indigenous people in indigenous territories and return migration to these territories (impact, see Figure 9).

Figure 9. Results framework
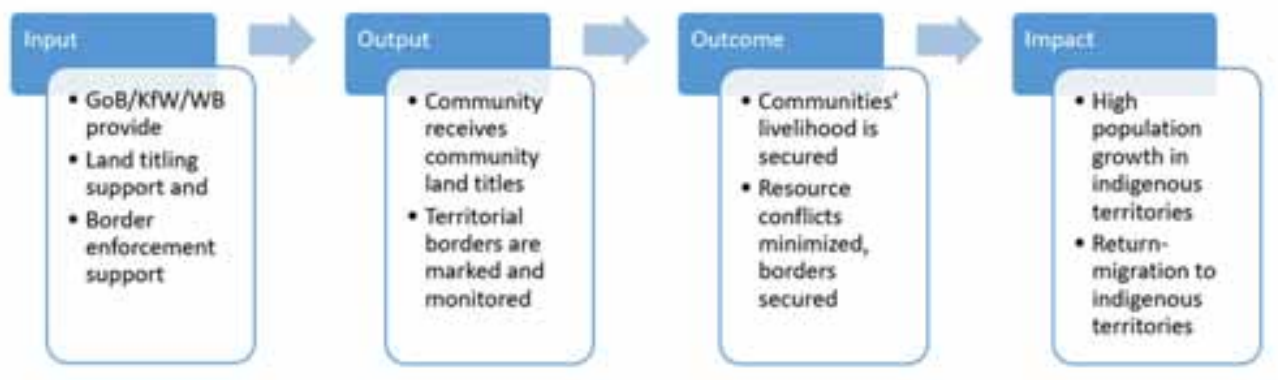

Source: Based on appraisal documents of KfW Development Bank and the World Bank. 
Several assumptions are necessary to this framework. First, indigenous communities and the IBAMA forest police are assumed to monitor the area and enforce the borders. Second, the previously mobile indigenous peoples that relied on hunting, gathering, and shifting cultivation for their livelihood are assumed to have adjust to their new territorial boundaries. Hypothetically, this policy of sedentarization may undermine the foundation of the indigenous societies, engendering a deterioration in their well-being; this was not apparent during the site visits.

Referring to the von Thünen theory presented in chapter one, demarcating indigenous territories and the sedentarization process will likely create small market centers surrounded by forest land used for shifting cultivations as shown in Figure 10. Sedentarization would thus alter the von Thünen framework by introducing nuclei of settlements into the isotropic plane to generate outliers of higher value or more intensive land use in the more remote areas.

Figure 10. Von Thünen model adapted for indigenous communities in the Brazilian Amazon

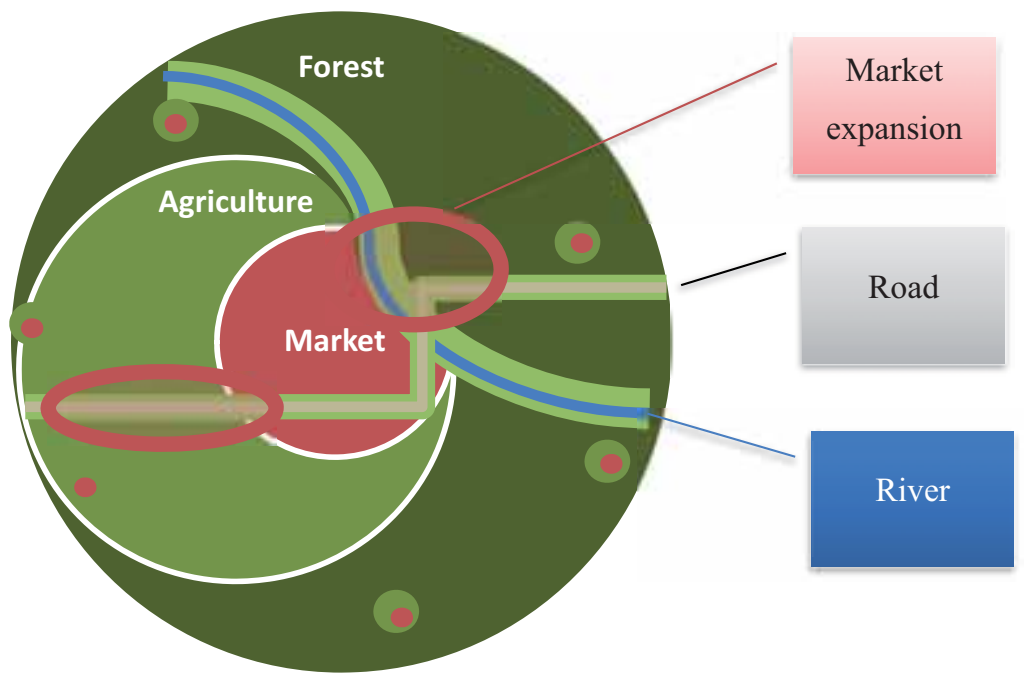

Source: Adapted from Angelsen 2007 and Fontes et al. 2017.

In the context of this research, creating higher land value could mean that people living in these centers will be better off due to the higher land value and greater profitability. The same is true for roads and rivers crossing the area. They lower transportation costs and link agricultural products closer to market centers. 


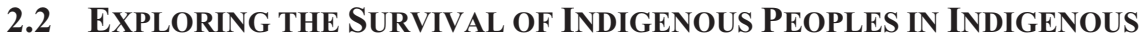 TERRITORIES FILLS A GAP IN THE LITERATURE}

The Brazilian Amazon covers about 4 million square kilometers of mostly rainforest, accounting for about 40 percent of the world's remaining rainforests (FAO 2011). These 4 million square kilometers are comparable to the combined territories of the 28 member states of the European Union, which comprise 4.4 million square kilometers. The Brazilian Amazon has about 3.3 inhabitants per square kilometer on average, much lower than the average of 116 people per square kilometer in the European Union, or the 20 inhabitants per square kilometer in the rest of Brazil.

According to Coimbra et al. (2013), 370 million indigenous peoples exist worldwide. Of these, about 50 million live in Latin America, and 896,917 people live in Brazil. Compared with other countries in Latin America, Brazil has one of the smallest shares of indigenous people compared with the overall population, only 0.4 percent.

The bulk of the indigenous population is in the Brazilian Amazon, where 71.5 percent of the population is concentrated in urban areas comprising just 1.2 percent of the original forest area of the Amazon (Tritsch 2016). Even with low average population densities, the rural areas are home to millions of people, including indigenous peoples, and non-indigenous rubber tappers, nut gatherers, fishers, and small farmers.

The literature on the indigenous population in the Brazilian Amazon focused on the decimation and near extinction of the indigenous people since the arrival of the Europeans (Lisansky 2005) and later through the Brazilian rural infrastructure and settlement policy (executed by INCRA, the National Agency for Land Reform, Hargrave et al. 2013) since the 1960s and up to this day (Alexiades 2009). However, more recently, the literature speaks about a turnaround and an increase in the indigenous population not only in Brazil, but in the whole of Latin America's tropical low lands (McSweeney et al. 2005).

McSweeney and Arps (2005) found for Central and South America, including Brazil, that indigenous women had a significantly higher fertility rate than non-indigenous contemporaneous women. According to the study, "for all countries included in this survey, indigenous women had significantly higher fertility-by about two births - than did contemporaneous non-indigenous rural women" (McSweeney and Arps 2005, p. 18), which 
can be related to poverty levels and positions on the margins of society. In addition, the mortality rate was declining dramatically so that most of the indigenous populations studied by McSweeney and Arps had a very young population.

Another phenomenon at play in Brazil is relevant for the current study. Brazil's 1988 Constitution and the right of the indigenous population to their lands and cultural identity made it more attractive for indigenous people to self-identify. According to McSweeney and Arps (2005, p. 5), “in Brazil, for example, some of the so-called 'growth' of the indigenous population appears to be an artifact of past undercounting of remote groups on the one hand, and on the other, social changes that have made more Brazilians willing and able to self-identify as indigenous [...]. It therefore remains unclear just how much of Brazil's indigenous 'demographic turnaround' [...] is attributable to actual physical replacement by established indigenous societies" (McSweeney et al. 2005).

Perz et al. (2008) come to the same conclusion that, for the 1990s, about 47 percent of the indigenous population increase can be attributed to reclassification as indigenous. According to Brazil's 2010 census and a 2012 publication on indigenous peoples, the reclassification occurred most prominently during the 1991-2000 decade, while the more recent population growth among indigenous peoples can be attributed to high fertility and reduced mortality (IBGE 2012). The four case studies in chapter two will shed light on this question by showing that some growth among the indigenous population in indigenous territories can be linked to return migration of urban-dwelling indigenous people to their indigenous lands.

\subsubsection{Land Tenure Security and Poverty}

Robinson et al. 2014 review the existing land tenure literature with respect to forest resource protection. They define property rights as a "bundle of rights guiding the use, management and transfer of assets" (p. 282). Furthermore, they define land tenure as a set of property rights associated with the land, and the institutions that uphold those rights. ${ }^{27}$ They follow the U.S. Agency for International Development (USAID; Katz 2010) in referring to land tenure as the set of institutions and policies that determine how land and its resulting resources are accessed,

\footnotetext{
${ }^{27}$ Robinson et al. 2014. follow USAID (Katz 2010) in referring to land tenure as the set of institutions and policies that determine how land and its resulting resources are accessed, who can benefit from these resources, for how long and under what conditions.
} 
who can benefit from these resources, for how long, and under what conditions (Robinson et al. 2014). Finally, they define land tenure security as the assurance that land-based property rights will be upheld by society. Even though according to Robinson et al. (2014) the literature tends to describe a continuum from private property rights as "secure" to no property rights as "insecure," they did not find any consistent correlation between tenure form and tenure security. They find that tenure security is far more important than any specific tenure form when it comes to forest protection.

According to Robinson et al. (2014), factors that contribute to increased land tenure security include: (1) absence of local conflict, (2) police enforcement, (3) no incidence of squatting, and (4) reliable monitoring capabilities. ${ }^{28}$ Furthermore, Robinson et al. (2014) find that the perception of land tenure security may be more important than the fact. This problem has also been described by Joppa et al.'s (2008) classification of de facto versus de jure protection.

Weak ownership and poverty are related. Sunderlin et al. (2008, p. 24) argues that "strong property rights on agricultural lands tend to translate to more secure livelihoods, investment, and the use of land titles for loan collateral [...]. Conversely, weak land and resource tenure tends to mean less secure livelihoods and lower incomes." This finding may also apply to community land rights of indigenous peoples as the following case study research will show. Here I explore how secure indigenous community land rights lead to secure access to resources and thus improved livelihoods, which forms a basis for increased population growth among the indigenous population living in indigenous territories.

\subsubsection{Research Gap}

My review found that the literature covers population growth of indigenous communities, tenure regimes, and the land rights of indigenous communities. To my knowledge, however, no other study has examined whether indigenous communities survive in indigenous territories in the Amazon and how their livelihood opportunities were affected by land demarcation and

\footnotetext{
${ }^{28}$ According to Robinson et al. 2014, "Thus the results may indicate cases where deforestation occurs with the intent of impacting tenure security (e.g., "clearing to claim," [...]) as well as cases where tenure security influences the decision to deforest. These models performed relatively well, correctly predicting $62-76$ percent of the observations in our sample and are qualitatively consistent with equivalently specified linear probability (ordinary least-squares) and logit models."
} 
monitoring support. This section will thus fill a research gap in the literature and explore how indigenous communities live and survive based on four case studies in the Brazilian Amazon.

\subsection{MethodologY-SEE THE Forest FOR THE TREES}

\subsubsection{Qualitative Research Methods}

To fill the research gap on how indigenous communities experience an amelioration of their livelihoods and survival in the context of demarcation, I use a mix of qualitative and quantitative research methods. There is a dearth of quantitative data about indigenous territories for the decades before 2010. Therefore, I triangulate my findings with census data and the literature to achieve more robust evidence. Before I use satellite data in chapter three, I want to see the forest for the trees, as the adage goes. I want to provide the field experience to create a context for the research that follows. Qualitative research methods allow a nuanced understanding of the living conditions and perceptions of the indigenous people. This section first defines relevant terms and then explains the research instruments used.

According to Yin 2009, a case study is "an empirical inquiry that investigates a contemporary phenomenon in depth and within its real-life context, especially when the boundaries between phenomenon and context are not clearly evident" (p. 18). Given that observations are often circumstantial and anecdotal, I use multiple sources of information to triangulate and understand the situation from multiple angles, cross-checking the evidence based on multiple data sources, including observations during the field research. According to Yin $(2009$, p. 18), "the case study inquiry copes with the technically distinctive situation in which there will be many more variables of interest than data points, and as one result relies on multiple sources of evidence, with data needing to converge in a triangulating fashion, and as another result benefits from prior development of theoretical propositions to guide data collection and analysis." Below, I discuss the theoretical propositions that guided my data collection and analysis.

Based on the classification of Morra Imas and Rist (2009)' I use the following case study evaluation methods, ordered from the more informal to the more formal:

(1) Field visits to selected indigenous territories

(2) Reviews of official records (management information system and administrative data)

(3) Key informant interviews

(4) Focus group discussions. Adjusting to the circumstances, no recordings were made 
(5) Direct observations

(6) Use of official IBGE census data.

I use obtrusive data collection methods meaning that I asked participants through interviews and focus groups about their perceptions, opinions, and attitudes. I thus made all our observations with the knowledge of those being observed.

This approach has clear limitations. Ideally, the researcher would have a year or two for indepth research and a large budget to visit a large sample of indigenous communities until there is saturation, meaning that additional visits to new indigenous communities do not reveal further insights into the issue under investigation. Essentially, the approach is following the law of diminishing returns. Instead, I follow the methodology of Carruthers and Chambers (1981): a rapid appraisal and rely on a purposive sample in selected representative communities according to a set of pre-determined criteria. I shared the criteria with the implementing agency FUNAI, which has extensive experience in managing and protecting indigenous territories and asked them for their help in identifying indigenous communities that met our selection criteria.

\subsubsection{Focus Group Methodology and Observation}

I planned for five to eight people to take part in each focus group. I was able to limit the number of participants in two of six focus groups conducted in the four indigenous territories. In the other two communities, other people listened in, although they may not have voiced their opinion (see Table 2).

Table 2. Number of participants per focus group

\begin{tabular}{|l|c|c|c|}
\hline Indigenous territory & $\begin{array}{c}\text { Number of participants } \\
\text { in focus group }\end{array}$ & Men & Women \\
\hline Paumari do Lago Marahã & 18 & 14 & 4 \\
\hline Jarawara / Jamamadi / Kanamati & 11 & 6 & 5 \\
\hline Tenharim Marmelos & 16 & 15 & 1 \\
\hline Tenharim Marmelos & 6 & 4 & 2 \\
\hline Diahui & 6 & 2 & 4 \\
\hline Total number of participants & $\mathbf{5 7}$ & $\mathbf{4 1}$ & $\mathbf{1 6}$ \\
\hline
\end{tabular}

Note: I conducted a focus group with the Paumari do Lago Marahã indigenous communities for men and women separately.

Source: Own table 
Before the field visit, I prepared a questionnaire consisting of 14 topics to be discussed with participants and translated into Portuguese. I shared the questionnaire with the implementing agency ahead of the field visit, which forwarded the guiding questions to the local FUNAI representatives (see guiding questionnaire in Table 3).

\section{Table 3. Issues discussed in focus groups sessions}

\begin{tabular}{|c|c|}
\hline Issues & Questions \\
\hline Demarcation process & $\begin{array}{l}\text { What worked well and what did not work well during the demarcation } \\
\text { process? }\end{array}$ \\
\hline $\begin{array}{l}\text { Support to the agenda of } \\
\text { indigenous people }\end{array}$ & $\begin{array}{l}\text { Did the Indigenous Lands Project support the indigenous agenda } \\
\text { and if yes in what ways? }\end{array}$ \\
\hline $\begin{array}{l}\text { Indigenous land rights in } \\
\text { Brazil }\end{array}$ & What is the status of indigenous land rights in Brazil? \\
\hline $\begin{array}{l}\text { Changes in enforcement } \\
\text { policy over time }\end{array}$ & $\begin{array}{l}\text { How has enforcing indigenous land rights evolved between } 1994 \text { and } \\
2013 ?\end{array}$ \\
\hline $\begin{array}{l}\text { Quality and quantity of } \\
\text { equipment }\end{array}$ & $\begin{array}{l}\text { How has the demarcation and enforcement equipment faired over } \\
\text { time? }\end{array}$ \\
\hline Deforestation & What is your perception of deforestation? \\
\hline Conflicts & $\begin{array}{l}\text { Are there any conflicts around natural resources (wood, fish, game, } \\
\text { minerals, etc.) and if so how do they play out? }\end{array}$ \\
\hline Legal extractive activities & How do oil, gas, and mining, impact indigenous territories? \\
\hline Infrastructure & How does road and dam construction impact indigenous territories? \\
\hline Livelihood & $\begin{array}{l}\text { Were there any changes in the livelihoods of indigenous } \\
\text { communities over the last five years? }\end{array}$ \\
\hline Demographics & Was there any population growth in indigenous territories? \\
\hline Migration & Did migration or return migration happen in your community? \\
\hline Indigenous organizations & What is the role of indigenous organizations in your community? \\
\hline Training & $\begin{array}{l}\text { Did your community receive any training under the Indigenous Lands } \\
\text { Project and if so what kind of training did it receive? }\end{array}$ \\
\hline
\end{tabular}

Source: Own table

In addition to the field visit to the four indigenous territories and focus group discussions, I spoke with government officials of the ministries of the environment and FUNAI at the central, regional, and local levels. In addition, I consulted a total of 46 representatives at all three governmental levels (national, state, and municipal), nongovernmental organizations, indigenous and non-indigenous in Brasília, Lábrea, Humaitá, and Manaus. I also interviewed a professor and his research team at the Amazonas State University of Manaus (Universidade Estadual do Amazonas, UEA). Back in Brasília, I presented preliminary findings with FUNAI, KfW, GIZ, and the local World Bank office (Table 4). In preparation for the field visit, I did not systematically focus on health issues, even though health was initially part of the project design, because in 1995, project managers decided to limit the project to demarcation and enforcement 
and cover health aspects under a different project. ${ }^{29}$ However, during the fieldwork, I noticed health units in indigenous communities, observed health outcomes, and met a dentist from Peru, providing pro bono dental services to indigenous children.

Table 4. Interviews conducted with key informants

\begin{tabular}{|c|c|c|}
\hline Type of organization & Name of organization & $\begin{array}{l}\text { Number of expert } \\
\text { interview partners }\end{array}$ \\
\hline Development bank & KfW Development Bank & 2 \\
\hline Development bank & World Bank & 2 \\
\hline NGO & Instituto Socioambiental, ISA & 3 \\
\hline NGO & Instiuto de Educação do Brasil, IEB & 1 \\
\hline Ministry in Brasília & Brazil's Indigenous organization, FUNAI & 9 \\
\hline Ministry in Brasília & Ministry of the Environment, MMA & 2 \\
\hline Local administrative branch & FUNAI Lábrea & 4 \\
\hline Indigenous NGO & $\begin{array}{l}\text { Federação das Organizações e Comunidades } \\
\text { Indígenas do Médio Purus, FOCIMP }\end{array}$ & 2 \\
\hline Indigenous NGO & $\begin{array}{l}\text { Associação das Mulheres Indígenas do Médio } \\
\text { Purus, AMIMP }\end{array}$ & 1 \\
\hline Indigenous NGO & OPAN — Operação Amazônia Nativa & 2 \\
\hline NGO & ICMBio & 1 \\
\hline Local administrative branch & FUNAI Humaitá & 4 \\
\hline $\begin{array}{l}\text { Bilateral implementing } \\
\text { agencies }\end{array}$ & German Technical Cooperation, GIZ & 3 \\
\hline Indigenous NGO & $\begin{array}{l}\text { Coordenação das Organizações Indígenas da } \\
\text { Amazônia Brasileira, COIAB }\end{array}$ & 3 \\
\hline University & UEA Universidade Estadual do Amazonas & 3 \\
\hline NGO & WWF Brasilien & 1 \\
\hline \multicolumn{2}{|c|}{ Total number of expert interviews } & 46 \\
\hline
\end{tabular}

Source: Own table

\footnotetext{
${ }^{29}$ Leuveld et al. (2018) noted for a project that tested financing agricultural extension services and input subsidies alone or in parallel that "providing training and demonstration trials alone is not enough to increase input demand needed to raise productivity. Lifting multiple barriers simultaneously could prove to be more effective." For the Indigenous Lands Project it would have been interesting to see if "lifting multiple barriers simultaneously" (Nillesen et al. 2018), such as demarcation, monitoring, and health would have been more effective. However, given that project managers decided to focus on demarcation and monitoring only, I can only speculate about possible results under a more complex project design.
} 
The following section will discuss the criteria used to select the four case studies.

\subsubsection{Selection Criteria for Field-Based Case Studies}

Brazil has a total of 27 federal states. The Legal Amazon includes the following nine Brazilian states: Acre, Amapá, Amazonas, Pará, Rondônia, Roraima, and parts of Maranhão, Mato Grosso, and Tocantins. Starting in 1995, FUNAI staff selected projects to be demarcated with financing from the Indigenous Lands Project in seven out of the nine states in the Amazon region (see Map 1).

\section{Map 1. Indigenous territories demarcated under the Indigenous Lands Projects}

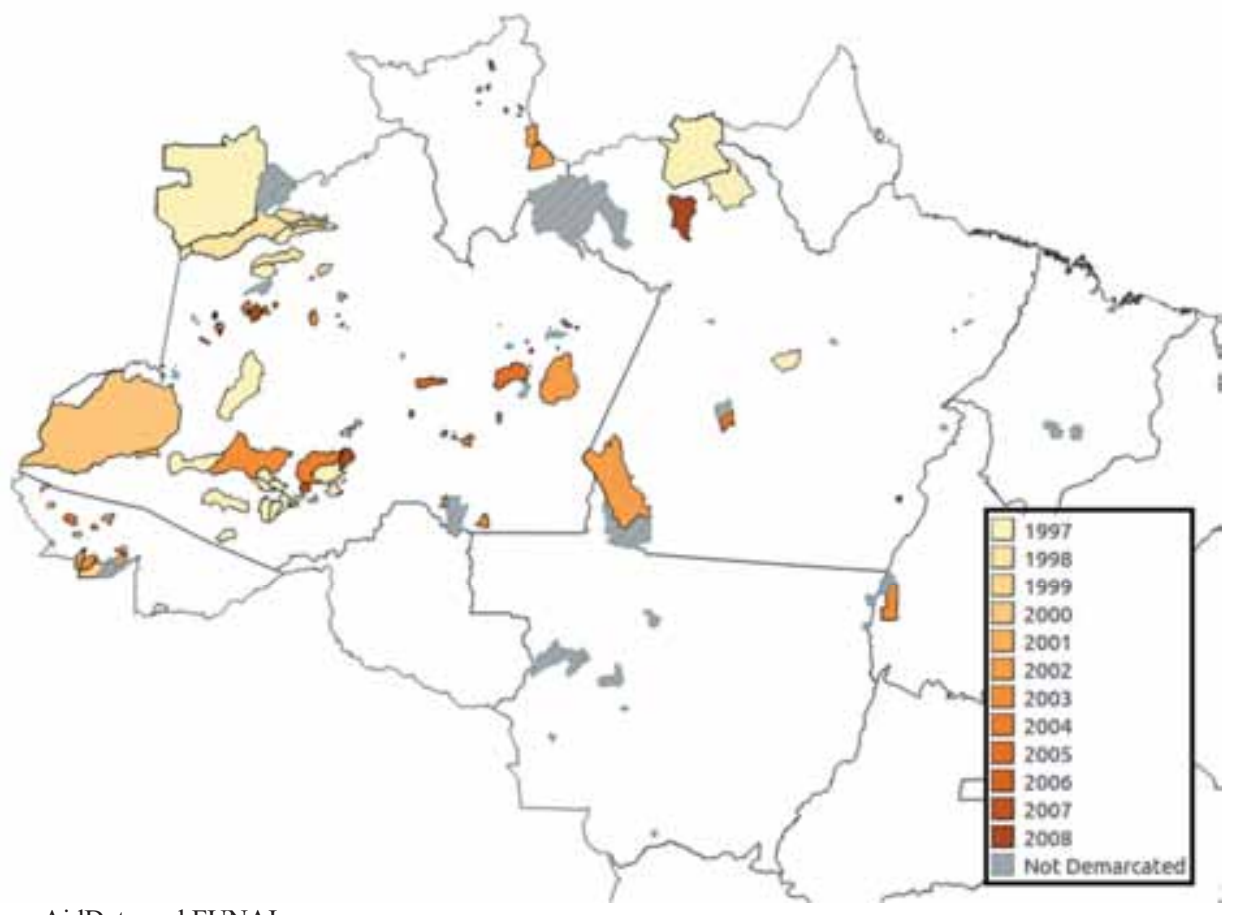

Source: AidData and FUNAI

The territories demarcated under the PPTAL project encompass an area of approximately 38 million hectares, roughly equivalent to the area of Germany (35 million hectares), but the Legal Amazon (or the five Brazilian states involved) extend over an area of about 5 million square kilometers, or about half of the continental United States, which made the logistics challenging. I overcame these challenges and increased comparability by focusing on the state of Amazonas with the most demarcated areas. The state of Amazonas includes 96 indigenous territories, or 63 
percent of all territories demarcated under the Indigenous Lands Project (see Figure 11 and Maps 1 and 2). Following George and Bennett (2005), I chose a most-different systems design to be able to draw conclusions from a small sample of only four case studies. These four indigenous territories would be found in the forest zone of the von Thünen conceptual model (Figure 10) and be illustrative of small-scale agricultural land use in the forest creating very small market centers. These four cases have been selected purposefully, because they provide diverse settings of remoteness from urban centers and threats from intruders.

\section{Figure 11. Number of indigenous territories by Brazilian state}

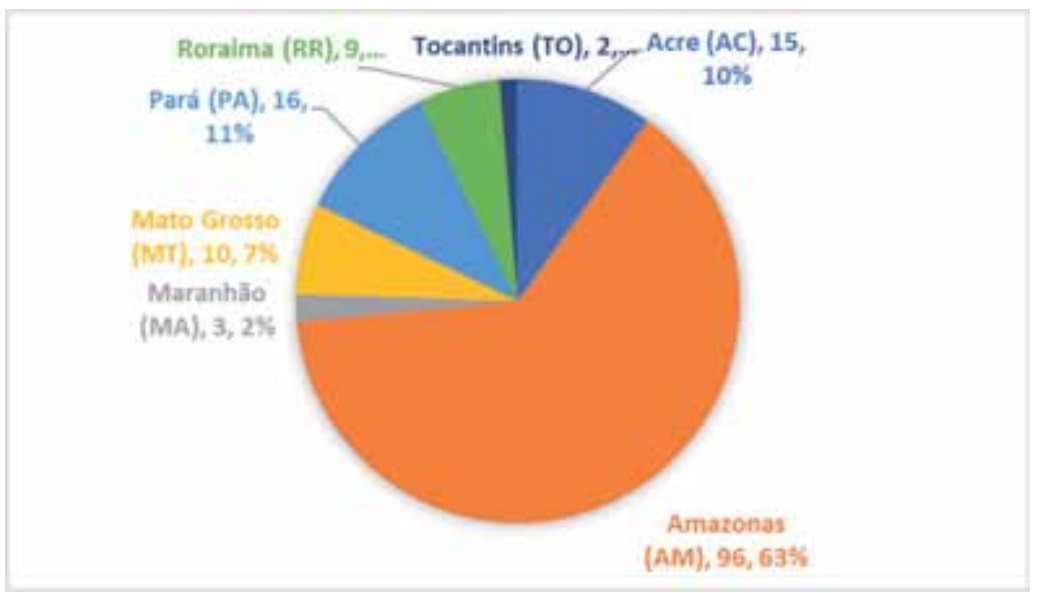

Source: FUNAI Database

Reaching the indigenous territories is not easy given they are spread over a vast area in the Brazilian Amazon. Together with a representative from FUNAI, a colleague from WWF, and a local consultant, I flew from the capital city of Brasília to Porto Velho and from Porto Velho to Lábrea, one of the larger municipalities in the state of Amazonas. Yet the location felt very remote. The airplane from Porto Velho was small and landed on a runway that looked more like a field than an airport runway. Approaching Lábrea, five forest fires were burning sending swaths of smoke columns into the air.

From Lábrea, the team took a motorboat and went four hours upstream along the Médio Purus passing by wooden houses located above the embankments. After about two hours, the settlements stopped and the rainforest (Mixed Ombrophilous Forest) became thicker and more majestic. We followed a tributary and finally arrived at the edge of the first indigenous territory we visited: Paumari do Lago Marahã (see Map 2). We walked another hour and finally arrived at a clearing and one of the villages of the Paumari do Lago Marahã. 
Map 2 provides the location of the four indigenous territories selected for the field visit. The area looks small on the map but feels very remote and distances are large. The black circles identify the four indigenous territories: Paumari do Lago Marahã and Jarawara/Jamamadi/Kanamati in the South of Amazonas State near Lábrea at the end of the Trans-Amazonian Highway and the Tenharim Marmelos and the Diahui near Porto Velho, further north. Coming back to the von Thünen theory as illustrated in Figure 10, Map 2 shows the location of the selected indigenous territories in the middle of the Amazon forest, away from major urban centers, but creating their own small market centers and surrounding agricultural production.

\section{Map 2. Four selected case study indigenous territories demarcated under the Indigenous Lands}

\section{Project with state boundaries}

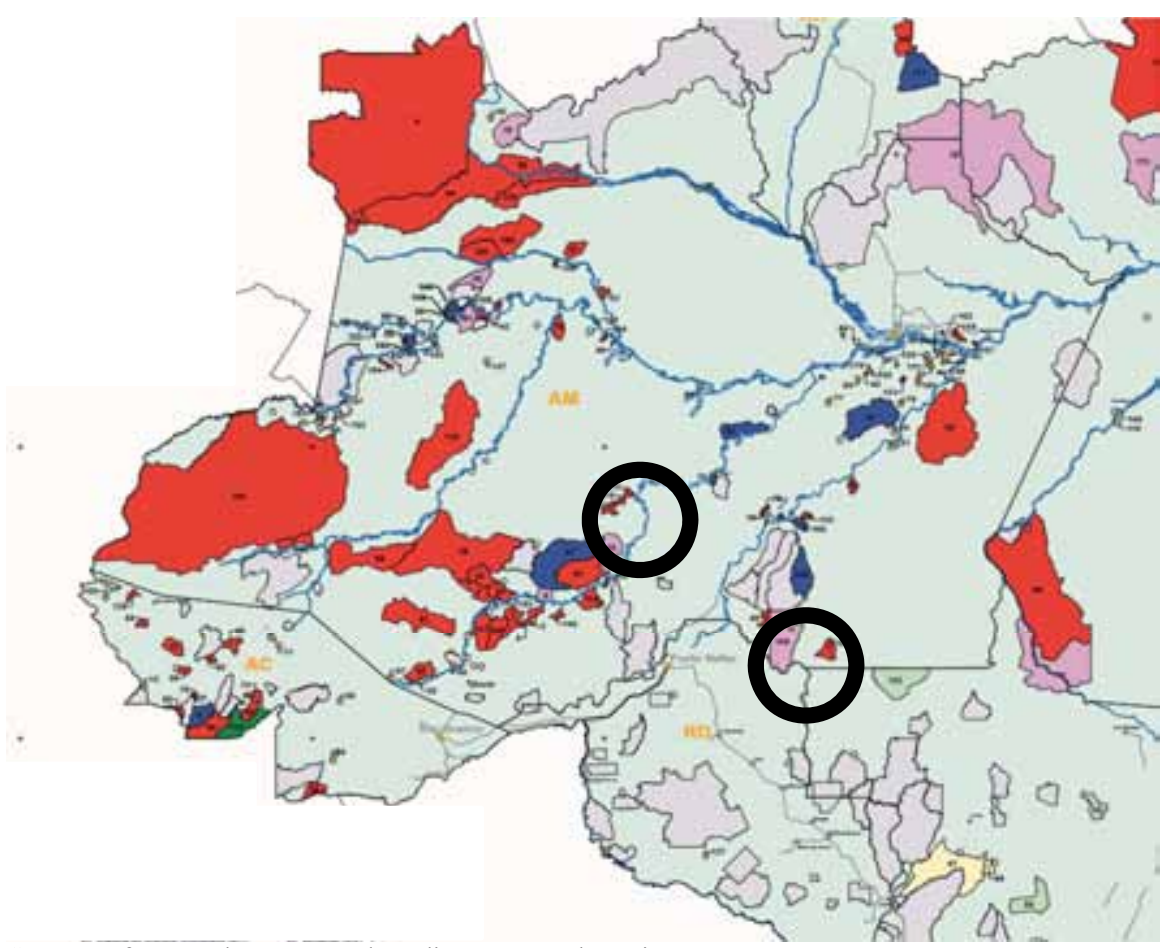

Source: KfW Development Bank. Indigenous Lands Project Map

Before the field visit, I provided FUNAI with the list of the following selection criteria for our indigenous lands case studies and field visits, to see a large range of different indigenous lands and learn about their demarcation experience:

(1) Demarcated in earlier versus later years

(2) With high versus low deforestation pressure 
(3) With presence versus absence of conflicts between indigenous peoples and adjacent farmers

(4) Closer to urban centers versus further away from urban centers

(5) Accessible via road versus more remote and accessible only via rivers

(6) Size of the territory: larger versus smaller

(7) Larger versus smaller populations.

The resultant choice comprised the following four indigenous territories: (1) Paumari do Lago Marahã (2) Jarawara/Jamamadi/Kanamati with the closest cities being Lábrea and Porto Velho and Tenharim/Marmelos and Diahui along the Trans-Amazonian Highway with the closest city being Humaitá (Table 5). All four territories were remote, located in the middle of the Brazilian Amazon. However, according to von Thünen (Figure 10), a few elements altered their remoteness in terms of the theory. A road going through an area will affect land and agricultural product price; this was obvious in the two indigenous territories along the Trans-Amazonian Highway. In addition, a river also can affect land and agricultural product prices, which could be observed in the two other indigenous territories, but to a much lesser degree. In order to adjust the model, I added symbols for roads and rivers to Figure 10, in order to adjust for the reality on the ground.

Table 5. Selected indigenous territories for case studies that were demarcated under the PPTAL project

\begin{tabular}{|c|c|c|c|c|c|c|}
\hline $\begin{array}{l}\text { Indigenous } \\
\text { territory }\end{array}$ & $\begin{array}{l}\text { Population } \\
\text { in } 1991\end{array}$ & $\begin{array}{l}\text { Population } \\
\text { in } 2006\end{array}$ & $\begin{array}{l}\text { Population } \\
\text { in } 2010\end{array}$ & $\begin{array}{l}\text { Demarcation } \\
\text { year }\end{array}$ & Location & $\begin{array}{l}\text { Size of } \\
\text { territory } \\
\text { (hectares) }\end{array}$ \\
\hline $\begin{array}{l}\text { Paumari do } \\
\text { Lago Marahã }\end{array}$ & 487 & 856 & 1,076 & 1998 & AM & 119,000 \\
\hline $\begin{array}{l}\text { Jarawara / } \\
\text { Jamamadi / } \\
\text { Kanamati }\end{array}$ & 338 & 400 & 527 & 1997 & AM & 390,000 \\
\hline $\begin{array}{l}\text { Tenharim } \\
\text { Marmelos }\end{array}$ & 298 & 460 & 535 & 2003 & AM & 498,000 \\
\hline Diahui & 30 & 88 & 113 & 2003 & AM & 47,000 \\
\hline
\end{tabular}

Source: FUNAI Database

Table 6 shows how the four cases reflect the seven selection criteria used to identify the cases. 
Table 6. Selection criteria to identify four indigenous territories for case studies

\begin{tabular}{|c|c|c|c|c|c|c|c|}
\hline $\begin{array}{l}\text { Indigenous } \\
\text { territory }\end{array}$ & $\begin{array}{c}\text {-1- } \\
\text { Early vs. } \\
\text { late } \\
\text { demarcation }\end{array}$ & $\begin{array}{l}-2- \\
\text { High vs. low } \\
\text { deforestation }\end{array}$ & $\begin{array}{c}\text {-3- } \\
\text { Conflicts }\end{array}$ & $\begin{array}{l}\text {-4- } \\
\text { Distance } \\
\text { to urban } \\
\text { centers }\end{array}$ & $\begin{array}{c}-5- \\
\text { Access }\end{array}$ & $\begin{array}{c}\text {-6- } \\
\text { Size of } \\
\text { territory }\end{array}$ & $\begin{array}{c}-7- \\
\text { Population } \\
\text { size }\end{array}$ \\
\hline $\begin{array}{l}\text { Paumari do } \\
\text { Lago } \\
\text { Marahã }\end{array}$ & Early & Low & Yes & $\begin{array}{l}\text { Further } \\
\text { away }\end{array}$ & River & Smaller & Larger \\
\hline $\begin{array}{l}\text { Jarawara/ } \\
\text { Jamamadi } \\
\text { /Kanamati }\end{array}$ & Early & Low & Yes & $\begin{array}{l}\text { Further } \\
\text { away }\end{array}$ & River & Larger & Larger \\
\hline $\begin{array}{l}\text { Tenharim } \\
\text { Marmelos }\end{array}$ & Late & High & Yes & Closer & Road & Smaller & Smaller \\
\hline Diahui & Late & High & No & Closer & Road & Larger & Smaller \\
\hline
\end{tabular}

Source: Own table

Having selected the four cases for the field-based case study analysis, I will next discuss the focus group methodology, observation, and triangulation with other data sources used for my qualitative data analysis.

The following section will present my data and additional data collection methodologies used to triangulate the four case studies.

\subsection{Case Study OVERVIEW}

\subsubsection{Data Collection Context}

The survival and well-being of the indigenous population was an important goal for the Indigenous Lands Project. Statistics from the IBGE, the Brazilian census bureau, and the Indigenous Lands Project indicate increased and high population growth in the last two decades. While some of the population increase in the 1990s can be explained by a reclassification of indigenous people rather than population growth alone (IBGE 2012), the 2000s show considerable average yearly population growth rates in rural areas of 3.7 percent as compared with 0.75 for Brazil's population (IBGE 2012). This speaks to a dramatic turnaround from near extinction to high population growth in demarcated indigenous territories. 


\subsubsection{Case Study 1-Indigenous Territory Paumari do Lago Marahã}

A wooden house stands at the entrance to the territory and a steep ladder leads to the second floor, or the living room (Photo 1). Below was space for storage. In this outpost of the village of the Paumari do Lago Marahã, a guard awaited us and showed us the way to the village.

Photo 1. Outpost house at the entrance to the indigenous territory of Paumari do Lago Marahã

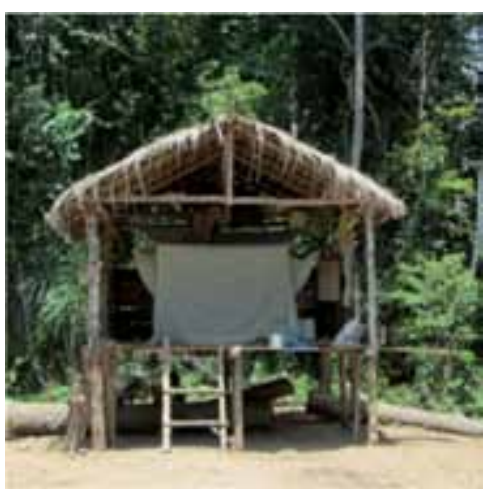

Credit: Silke Heuser

An hour-long hike along small footpaths through the rainforest took us to the first sign of human activity, a burned field in the middle of the forest. Soon after, the forest opened to a large clearing that looked like an airfield. Both sides were lined with wooden houses on stilts (Map 3).

More than one hundred people lived in this village. It was an evangelical parish, run by a German mission called "Deutsche Indianer Pioner Mission" and was part of the Indigenous Missionary Council (CIMI-Conselho Indigenista Missionário). ${ }^{30}$ The wooden church building would serve the research team as a space to put up hammocks for the night.

The Paumari do Lago Marahã territory has a surface area of 118,777 hectares and a perimeter of 239 kilometers. Before 2000, it had a relatively low accumulated deforestation area, 695 hectares. Between 2000 and 2014, some 1,055 hectares were deforested. The number of fires for 2015 to 2017 as observed in satellite imagery peaked in August 2016 with 24 fires, compared to about 8 in 2015 (Annex A, Table 32 and Table 33). ${ }^{31}$

\footnotetext{
${ }^{30}$ Retrieved on March 20, 2017, from: https://terrasindigenas.org.br/pt-br/terras-indigenas/3962.

${ }^{31}$ Retrieved on March 22, 2017, from: https://terrasindigenas.org.br/pt-br/terras-indigenas/3946.
} 
Map 3. Indigenous territory Paumari do Lago Marahã-Remote location far from the agricultural frontier

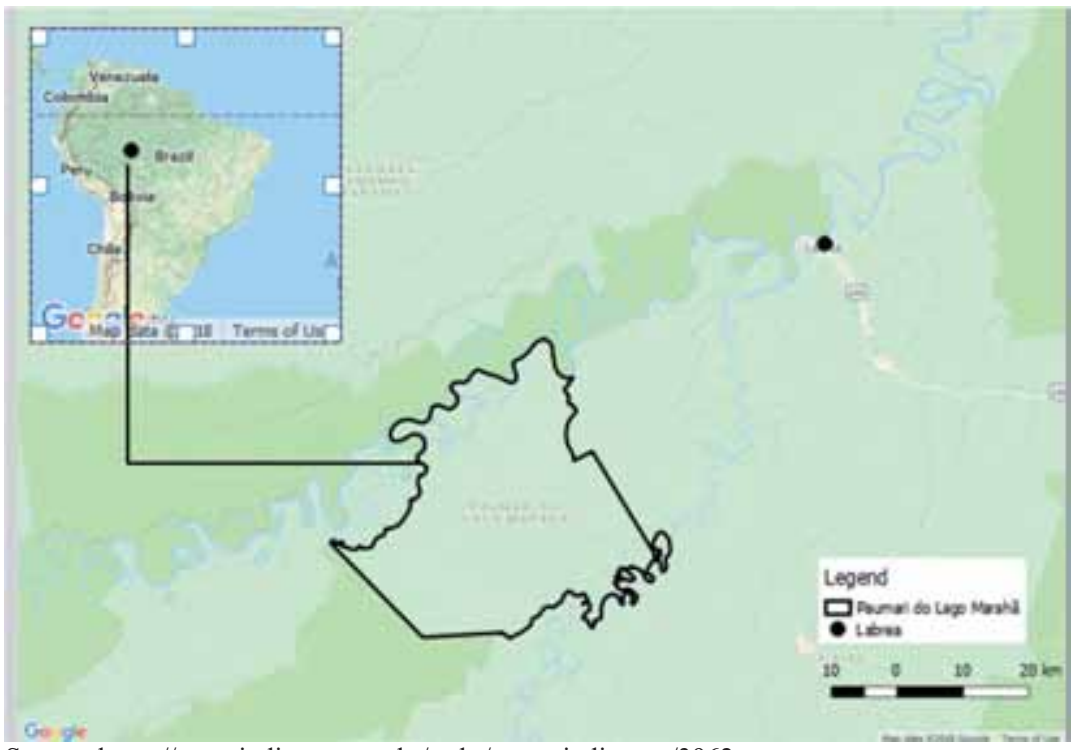

Source: https://terrasindigenas.org.br/pt-br/terras-indigenas/3962

At the borders of the indigenous territory, a mining company extracts tantalite, used for cellphones and other electronic devices. In 2015, another request started for gold mining in an area of 9,777 hectares adjacent to the indigenous reserve. This shows that an indigenous territory in a remote area is threatened by extractive industries. However, the demarcated border line of the territory forms a buffer to prevent extraction within the territory.

FUNAI identified Paumari do Lago Marahã territory for demarcation in May 1987. The delimitation stage concluded in May 1992 after study of the territory had been completed. The Indigenous Lands Project started in 1995 with financing for the demarcation stage and demarcation was completed in January 1998. The official recognition stage was finalized in August of that year with the signature of Brazil's president, Fernando Henrique Cardoso, and in March 2000, the Paumari do Lago Marahã territory reached the final registration stage, by which all the land titling data had been entered in the official registries, thus securing the community land title of Paumari do Lago Marahã indigenous land.

In addition to the indigenous land titling process, the Indigenous Lands Project financed training sessions, boats, motors, fuel, and radios to help the indigenous communities monitor their lands. For the Paumari do Lago Marahã territory, the project provided support to a number 
of indigenous communities along the river of the Middle Purus, starting in 2002. The indigenous organization Operação Amazônia Nativa (OPAN), founded in 1969 and one of the oldest indigenous organizations in Brazil, conducted the forest and land monitoring training for the Middle Purus region.

Photo 2. Traditional dances in the indigenous territory of the Paumari do Lago Marahã

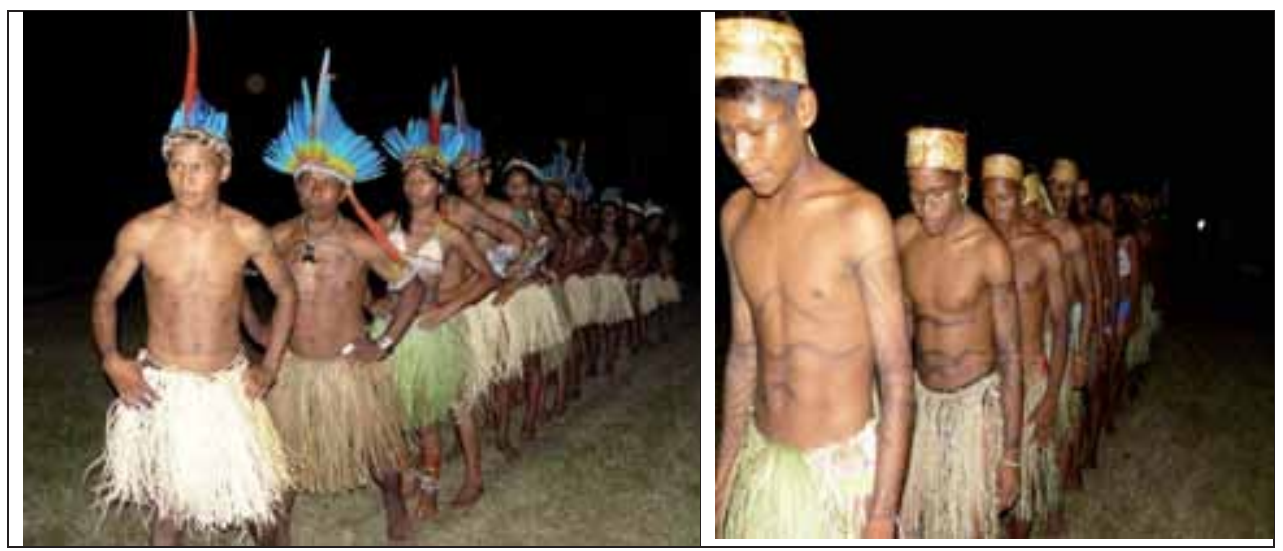

Credit: Roberto Maldonado

In the evening the research team served as judges for the best traditional dance performed by the different families (see Photo 2). After a night in a hammock the research team set off to the next indigenous territory.

\subsubsection{Case Study 2-Indigenous Territory Jarawara/Jamamadi/Kanamati}

To reach the indigenous territory of the Jarawara/Jamamadi/Kanamati, the team took a boat upstream and past a reserve where rubber tappers were extracting rubber from trees. The houses of the rubber tappers were clustered closely together in a village with the rubber trees behind. On the other side of this village was the indigenous territory of the Jarawara/Jamamadi/ Kanamati. To reach the village, the research team pulled the boat on land and hiked two hours through the rainforest until we reached a stream that prevented us from going further. We had to walk along and look for a canoe to cross the stream. On the way to the village, we met two young men, not older than 15, carrying guns for hunting while patrolling the area. The focus group I conducted in this territory revealed that the monitoring and enforcement training focused in this territory and that people were still using some of the skills and practices learned, which had now been 
passed on to the younger generation. We continued the journey until we arrived again at a clearing. The village again looked like a vast airfield with houses lining the borders (see Map 4).

\section{Map 4. Indigenous territory Jarawara/Jamamadi/Kanamati-Remote location far from the agricultural frontier}

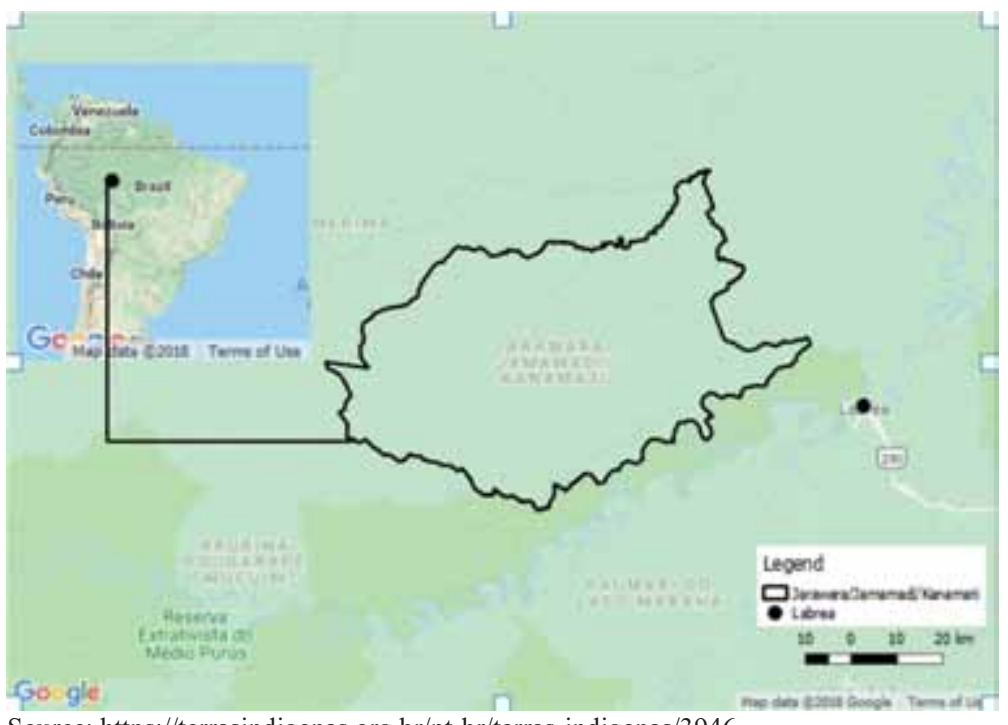

Source: https://terrasindigenas.org.br/pt-br/terras-indigenas/3946

Women and their children sat on a deck where they were involved in handicrafts. One of the women was expecting a baby and asked for our names, promising to call the baby by one of our names.

In terms of their physical characteristics, the indigenous territory of the Jarawara/Jamamadi/ Kanamati is densely covered by rainforest (Mixed Ombrophilous Forest, tolerant of humidity and typical for the Brazilian rainforest). It extends over an accumulated area deforested before 2000 amounting to 2,236 hectares, a slightly smaller per hectare deforestation area than in the Paumari do Lago Marahã territory ( 0.8 percent deforested area for the Jarawara/ Jamamadi/Kanamati territory, compared with 0.9 percent for the Paumari do Lago Marahã). The accumulated area deforested between 2000 and 2013 amounted to 3,010 hectares. The number of fires for 2015 to 2017 as observed in satellite imagery peaked in September 2015 with 30 fires, compared to about 7 in $2016 .{ }^{32}$ No extractive industry directly borders the territory, though tantalite and gold extraction takes place not far away.

\footnotetext{
${ }^{32}$ Retrieved on March 22, 2017, from: https://terrasindigenas.org.br/pt-br/terras-indigenas/3946.
} 
FUNAI identified the Jarawara/Jamamadi/Kanamati territory for demarcation in May 1988. The delimitation stage involved studies and the participation of the indigenous people and concluded in November 1991. After the start of the Indigenous Lands Project in 1995, the indigenous territory concluded the demarcation stage in December 1997 and was thus one of the first communities demarcated under the project. The territory completed the official recognition stage in April 1998 with the signature of Brazil's president, Fernando Henrique Cardoso. In July 2002, the Jarawara/Jamamadi/Kanamati territory reached the final registration stage, by which date all the land titling data had been entered in the official registries, thus securing the community land title of Jarawara/Jamamadi/Kanamati indigenous land.

As in Paumari do Lago Marahã, the Indigenous Lands Project financed training sessions, boats, motors, fuel, and radios to help the indigenous communities monitor their lands. For the Jarawara/Jamamadi/Kanamati territory, the project provided support to several indigenous communities along the river of the Middle Purus, starting in 2002. The indigenous organization OPAN conducted the forest and land monitoring training for the Middle Purus region.

\subsubsection{Case Study 3-Indigenous Territory Tenharim/Marmelos}

The indigenous territory of the Tenharim/Marmelos is situated along the Trans-Amazonian Highway, a road that cuts through the Brazilian Amazon from the Eastern city of Itaituba to Humaitá and ending in Lábrea in the west, toward the border with Peru. Because of the vast extent of the state of Amazonas and time constraints, the research team flew from Lábrea to Humaitá and took a car about two hours on the "gravel road highway" called Trans-Amazonian Highway to the indigenous territory of the Tenharim/Marmelos.

On arrival in the indigenous territory, I found a village spread out along both sides of the road. This village looked clearly wealthier than either of the two previous ones. It was situated on a major road, had many brick buildings, a fountain and running water, a school building, a health clinic, large TV screens in the school building, and a high-speed internet connection (see Map 5). The location of this village along the road and its greater prosperity can be explained by the von Thünen theory (Figure 10) that predicts land value and agricultural product price to increase in proximity to a road. 


\section{Map 5. Indigenous territory Tenharim/Marmelos-Proximity to a major road and to an agricultural frontier}

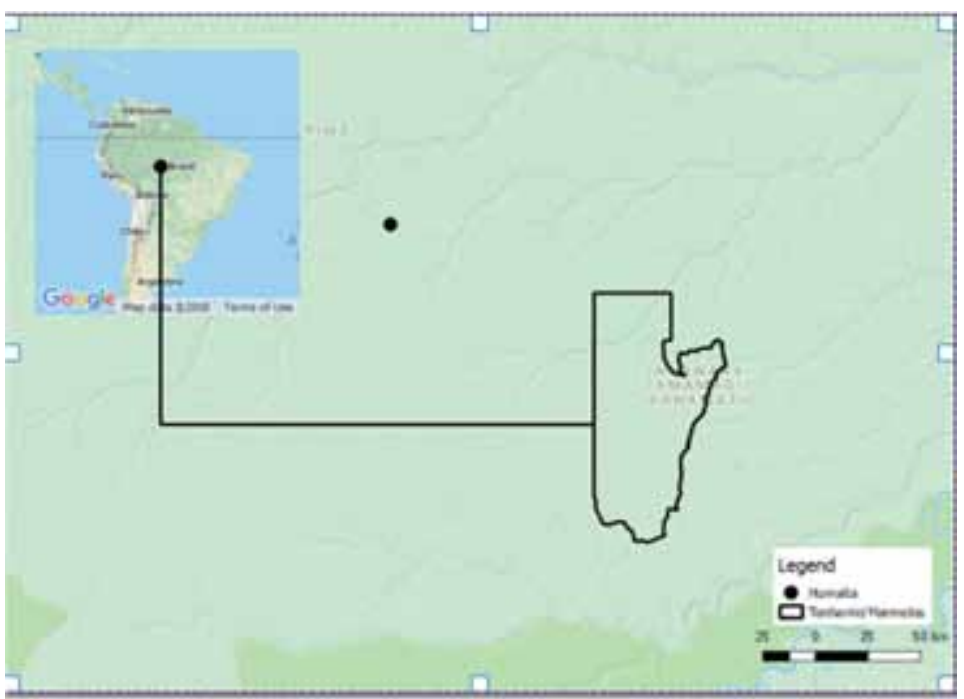

Source: https://terrasindigenas.org.br/pt-br/terras-indigenas/3869

The Tenharim/Marmelos are part of the Tenharim people and they speak the Kawahib language, which is part of the Tupi-Guarani linguistic family. ${ }^{33}$ In terms of its physical characteristics, the indigenous territory of the Tenharim/Marmelos is densely covered by mixed tropical rainforest.

The indigenous territory of the Tenharim/Marmelos is a buffer against one of the most deforested and heavily studied areas in the state of Amazonas, the Manicoree region with the frontier city of Santo Antônio do Matupi at kilometer 180 along the Trans-Amazonian Highway. ${ }^{34}$ In the city, I found 32 sawmills, 5 of them legal. While driving on the Trans-Amazonian Highway, I noticed many heavily loaded trucks with enormous trunks of valuable trees.

\footnotetext{
${ }^{33}$ Retrieved on March 25, 2017, from: https://terrasindigenas.org.br/pt-br/terras-indigenas/3869.

34 The Trans-Amazonian Highway (official designation BR-230, official name Rodovia Transamazônica), was introduced on September 27, 1972. It is 4,000 kilometers long, making it the third longest highway in Brazil. It runs through the Brazilian states of Paraíba, Ceará, Piaui, Maranhão, Tocantins, Pará and Amazonas, from the proximities of Saboeiro up until the town of Lábrea. Retrieved on March 30, 2017, from: https://en.wikipedia.org/wiki/Trans-Amazonian_Highway.
} 
The indigenous territory of the Tenharim/Marmelos extends over an area of 498,521,000 hectares with a perimeter of 419 kilometers. The area deforested in the Tenharim/Marmelos territory was relatively low before 2000 with 1,405 hectares and increased to 2,247 hectares between 2000 and 2014. The proportion of area deforested in the 2000 to 2014 period relative to the size of the territory was 0.5 percent for the Tenharim/Marmelos as compared with 0.9 percent for the Paumari do Lago Marahã and 0.8 percent for the Jarawara/ Jamamadi/Kanamati.

The number of fires for 2015 to 2017 as observed in satellite imagery peaked at 158 fires in August 2015, compared with about 88 fires in August of $2016 .{ }^{35}$ Seven extractive enterprises operate in the area bordering the territory and in two instances even operate within the borders of the Tenharim/Marmelos territory. Enterprises worked on extracting tin, cassiterite, a tin oxide mineral, wolframite, and gold. All permits, except the two cassiterite permits from 2008 and 2012, were granted before the territory had been demarcated (Table 7).

Table 7. Physical characteristics of the Tenharim/Marmelos indigenous territories

\begin{tabular}{|c|c|c|c|c|c|c|}
\hline Name & Surface & Perimeter & Type of forest & $\begin{array}{l}\text { Deforested } \\
\text { area }\end{array}$ & Minerals & Extraction \\
\hline $\begin{array}{l}\text { Tenharim/ } \\
\text { Marmelos }\end{array}$ & $\begin{array}{c}498 \\
\text { million } \\
\text { hectares }\end{array}$ & $\begin{array}{c}419 \\
\text { kilometers }\end{array}$ & $\begin{array}{c}\text { Contato Savana- } \\
\text { Floresta Ombrófila: } \\
\text { 14.43\%; Contato } \\
\text { Savana-Formações } \\
\text { Pioneiras: } 27.88 \% \text {; } \\
\text { Floresta Ombrófila } \\
\text { Abert: } 2.18 \% \text {, and } \\
\text { Floresta Ombrófila } \\
\text { Densa: } 55.51 \%\end{array}$ & $\begin{array}{c}2,247 \\
\text { hectares } \\
(2000-2014)\end{array}$ & $\begin{array}{c}\text { Tin, } \\
\text { cassiterite, } \\
\text { wolframite, } \\
\text { and gold }\end{array}$ & $\begin{array}{c}1991 \text { request for } \\
2,513.57 \text { ha } \\
1991 \text { request for } \\
775.03 \text { ha } \\
2008 \text { request for } \\
9,645.42 \text { ha } \\
2012 \text { request for } \\
3,750.62 \text { ha } \\
1985 \text { request for } \\
10,041.56 \text { ha } \\
1995 \text { request for } \\
9,858.48 \text { ha } \\
1995 \text { request for } \\
2,220.40 \text { ha }\end{array}$ \\
\hline
\end{tabular}

Source: ISA—https://terrasindigenas.org.br/pt-br/terras-indigenas.

FUNAI identified the Tenharim/Marmelos territory for demarcation in March 2002. The delimitation stage involved studies and the participation of the indigenous people themselves

\footnotetext{
${ }^{35}$ Retrieved on March 22, 2017, from: https://terrasindigenas.org.br/pt-br/terras-indigenas/3946.
} 
and concluded in December 2002. The Indigenous Lands Project concluded the demarcation stage in July 2003. This territory belongs to the group of indigenous lands that were demarcated in the second half of the Indigenous Lands Project. The territory completed the official recognition stage in October 2003 with the signature of Brazil's president, Luiz Inácio Lula da Silva. In January 2004, the Tenharim/Marmelos territory reached the final registration stage, by which date all the land titling data had been entered in the official registries, thus securing the community land title.

The Tenharim/Marmelos people did not receive any monitoring and enforcement support under the Indigenous Lands Project.

\subsubsection{Case Study 4-Indigenous Territory Diahui}

The indigenous territory of the Diahui is situated along the Trans-Amazonian Highway as well, but closer to Humaitá than the territory of the Tenharim/Marmelos. The research team arrived in the indigenous territory of the Diahui on the southern side of the Trans-Amazonian Highway and found round traditional meeting halls made of straw and rising high up. This was the only indigenous community where the team saw this type of meeting hall (see photo 6). The Diahui, although not far from the Tenharim/Marmelos seemed to live a more traditional life than their neighbors involving less wealth and resources. According to the history of this people, a rich farmer had invaded most of the Diahui land before the demarcation. However, land demarcation had allowed the Diahui to prosper and many members of their family who had gone to cities came back to their traditional lands, forming a separate village (Map 6). 
Map 6. Indigenous territory Diahui-Proximity to a major road and within the boundaries of a farm that was evicted during the demarcation process

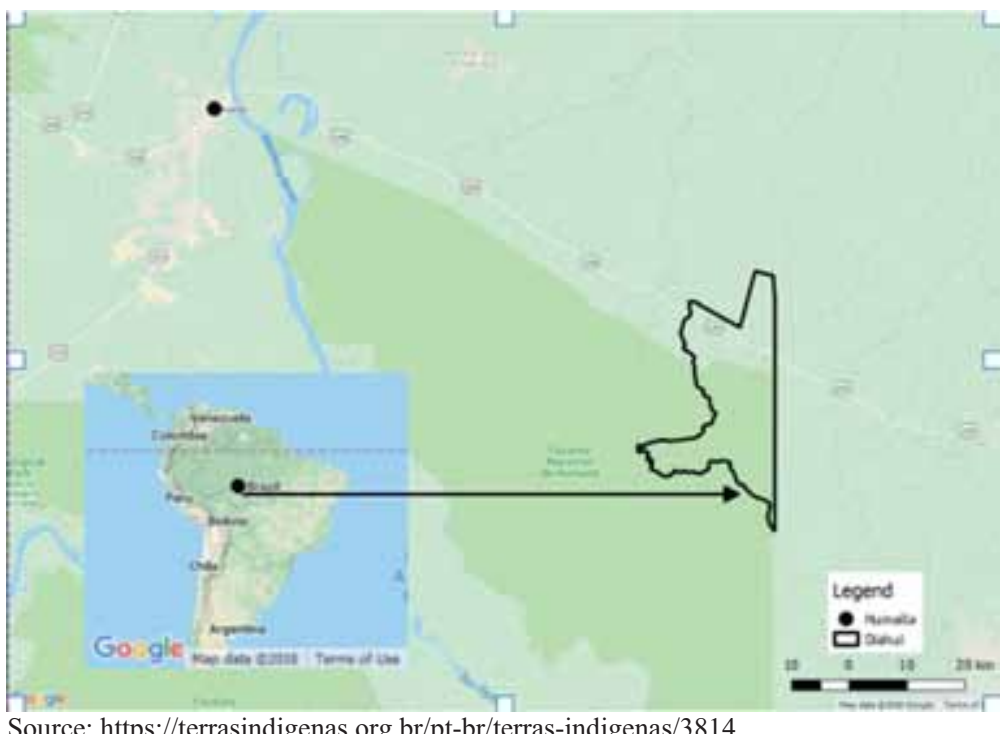

The Diahui belong to the Jiahui people, who speak the Diahui language, which is part of the Tupi-Guarani linguistic family. In terms of its physical characteristics, the indigenous territory of the Diahui is less densely covered by tropical rainforest than the other indigenous territories, since this territory used to belong to a large farm. At the time of demarcation in 2003, legal non-indigenous settlers and farmers that lived in indigenous territories before Brazil's 1988 Constitution became effective were evicted from the indigenous land and compensated for their investments in buildings and other assets, but not for the land. ${ }^{36}$

The indigenous territory of the Diahui extends over an area of 47,354 hectares with a perimeter of 152 kilometers. The area deforested in the Diahui territory was relatively high before 2000 1,879 hectares (or 4.1 percent of the indigenous territory) - but did not change afterwards (see Table 8).

\footnotetext{
${ }^{36}$ Non-indigenous residents received compensation only in those cases where they settled in "boa fe," not knowing about the existence of the indigenous territory.
} 
Satellite imagery showed only three fires for August 2015, compared with five fires in July $2016 .{ }^{37}$ Wood is the only natural resource extracted from the territory, although it borders an area where cassiterite is extracted. ${ }^{38}$

Table 8. Physical characteristics of the Diahui indigenous territory

\begin{tabular}{|c|c|c|c|c|c|c|}
\hline Name & $\begin{array}{l}\text { Surface } \\
\text { in } \\
\text { hectares }\end{array}$ & $\begin{array}{l}\text { Perimeter } \\
\text { in } \mathrm{km}^{2}\end{array}$ & Type of forest & $\begin{array}{l}\text { Deforested } \\
\text { area }\end{array}$ & Minerals & Extraction \\
\hline Diahui & 47,354 & 152 & $\begin{array}{c}\text { Rainforest } \\
\text { (Mixed } \\
\text { Ombrophilous } \\
\text { Forest) }\end{array}$ & $\begin{array}{c}1,879 \text { hectares } \\
\text { before } 2000, \\
\text { none thereafter }\end{array}$ & $\begin{array}{l}\text { Cassiterite } \\
\text { and wood } \\
\text { extraction }\end{array}$ & $\begin{array}{l}\text { None } \\
\text { listed }\end{array}$ \\
\hline
\end{tabular}

Source: ISA—https://terrasindigenas.org.br/pt-br/terras-indigenas.

FUNAI identified the Diahui territory for demarcation in March 1999. The delimitation stage involved studies and the participation of the indigenous people and concluded in April 2001. The Indigenous Lands Project concluded the demarcation stage in February 2003. This territory therefore belongs to the group of indigenous lands that were demarcated in the second half of the Indigenous Lands Project. The territory completed the official recognition stage in October 2004 with the signature of Brazil's president, Luiz Inácio Lula da Silva. In June 2006, the Diahui territory reached the final registration stage, by which date all the land titling data had been entered in the official registries, thus securing the community land title.

\subsection{Case Study Results-Demarcation, A Blessing or Curse}

In this section, I present case study results. Analyzing these case studies will help explore whether (1) demarcation and enforcement took place; (2) where indigenous people draw their livelihood from; (3) the level of basic services in indigenous territories; and (4) whether indigenous people actually live in indigenous territories. These sections will help further explore whether demarcating indigenous territories led to improvements in indigenous peoples' livelihoods and survival.

\footnotetext{
${ }^{37}$ Retrieved on March 31, 2017, from: https://terrasindigenas.org.br/pt-br/terras-indigenas/3814\#direitos.

${ }^{38}$ Retrieved on March 31, 2017, from: https://terrasindigenas.org.br/pt-br/terras-indigenas/3814\#direitos.
} 


\subsubsection{Demarcation and Enforcement}

The field visit to four indigenous communities in the Brazilian Amazon enabled me to confirm that demarcation did take place. During the field verification, I reviewed contracts in the KfW file registry, I spoke with FUNAI representatives who showed me georeferenced maps of the demarcated indigenous territories, and I was able to see the difference inside an indigenous territory where the tree canopy was thick and closed, with outside the indigenous territory, where cattle grazed and only a few trees were left standing.

Initially, FUNAI demarcated the territory by cutting six-meter-wide forest aisles on the border of the indigenous territory and put concrete blocks as landmarks in the ground. Landmarks marked the area in one-kilometer increments. The demarcation engineers, in cooperation with the indigenous people, georeferenced some of these landmarks using a Global Positioning System (GPS) device. This helped in mapping the indigenous territories both on paper and digitally in the form of shape files. The engineers also marked the entrance to the indigenous territory along the Trans-Amazonian Highway using panels. During the field visit, I verified the landmarks and panels that could still be found (see Photo 3).

\section{Photo 3. Land demarcation through GPS mapping, panels, and demarcation stones}
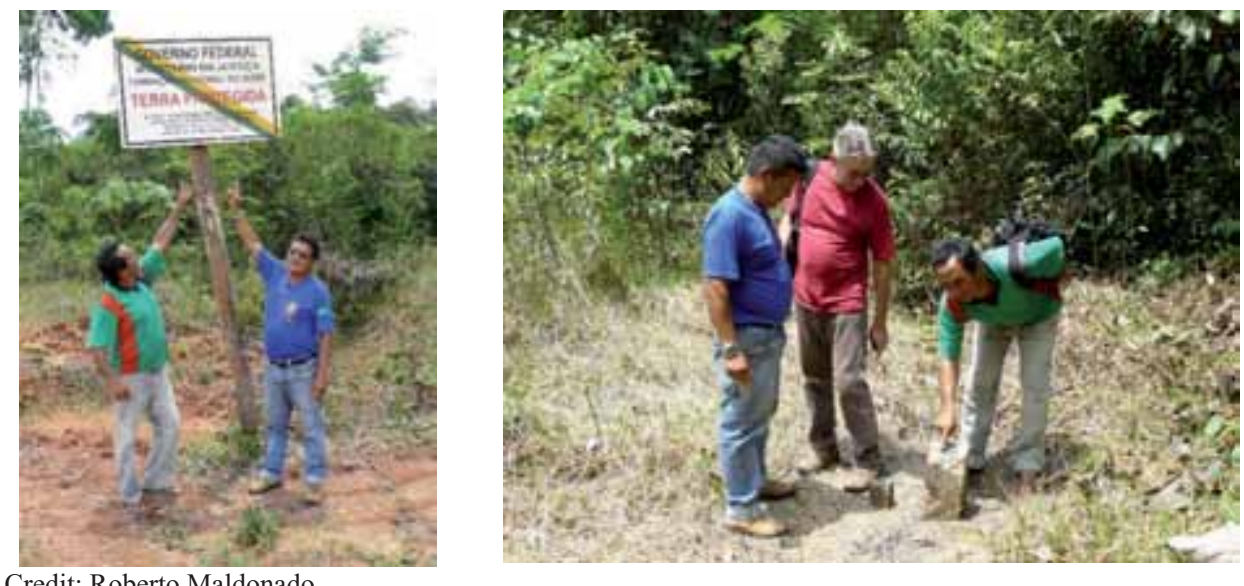

At the beginning of the Indigenous Lands Project, FUNAI conducted all the demarcation for the indigenous peoples. The project developed a demarcation process that involved the indigenous people, who learned how to use GPS devices for georeferencing and took responsibility for monitoring and safeguarding the borders and their territory by patrolling and the using communication devices. In the earlier years, the Indigenous Lands Project cut the six- 
meter-long forest aisles (which was labor-intensive and expensive), but the project later introduced an innovation from FUNAI - plant rows of a specific kind of tree to mark borders.

By involving the indigenous people in a participatory manor in the demarcation process, the project helped the people learn about technical issues and informed them of their rights and responsibilities. ${ }^{39}$ This resulted in a stronger self-organization of indigenous people and led to the indigenous people playing a more important role within FUNAI as well as in Brazilian society as a whole. This was showcased, for example, through the consultation process that led to the ratification of the 2012 policy on the Environment and Land Management in Indigenous Territories (Política Nacional de Gestão Territorial e Ambiental de Terras Indígenas, PNGATI, Decreto $\mathrm{n}^{\mathrm{o}}$ 7.747, July 5, 2012).

The indigenous organization COIAB (Coordenação das Organizações Indigenas da Amazônia Brasileira) in Manaus, for example, started to become active even beyond the borders of Brazil by building an umbrella organization for indigenous NGOs in Bolivia, Brazil, Colombia, Ecuador, Guyana, Peru, Suriname, and Venezuela. The indigenous engagement contributed to the latest achievement in terms of indigenous rights at the international level. In 2007, the UN General Assembly adopted the UN Declaration on the Rights of Indigenous Peoples. This declaration stipulates: "Indigenous peoples have the right to the lands, territories and resources which they have traditionally owned, occupied or otherwise used or acquired."40

Another result noticeable from looking at the maps was that indigenous territories looked greener and the canopies appeared to be more intact in indigenous territories as compared with areas outside the indigenous territory. The literature that compares indigenous territories with areas that are not protected using statistical methods (Nepstad et al. 2006, Nelson and Chomitz 2011, Nolte et al. 2013, Pfaff et al. 2014, Vergara-Aseno and Potvin 2014), finds a noticeable difference in terms of forest preservation between the area inside and outside of indigenous

\footnotetext{
${ }^{39}$ We follow Maier et al. (2014) in terms of defining 'participation' when they state: "Traditionally, participation in a representative democracy has referred to representation via voting for representatives to make future decisions. Yet, in the (post-)modern debate on governance, participation goes beyond such an understanding. Rather, in public and academic discussions it is understood as the involvement of non-state actors - organizations and the general public at large - in the policy-making process."

${ }^{40}$ Retrieved on September 1, 2008, from: https://www.un.org/development/desa/indigenouspeoples/declarationon-the-rights-of-indigenous-peoples.html.
} 
lands. In chapter three, I will analyze this question further by comparing the effect of forest preservation between demarcated with not yet demarcated lands using impact evaluation methodology.

Verifying enforcement training proved more challenging than demarcation. Based on a database shared by FUNAI that included contract number and days, I was able to verify which territories received enforcement training and for how long. Focus group discussions during the field trip enabled me to verify that in two out of the four territories enforcement training took place. In addition, Brazil's forest police, IBAMA monitors deforestation via a satellite system that provides deforestation data every two weeks.

According to the database shared by FUNAI, the NGO OPAN conducted the monitoring and enforcement training sessions in the areas visited. During the field visit, I was able to see patrolling in action. On the way to the indigenous territory, I met two young men going hunting and patrolling the area (see Photo 4). A boat for patrolling the area had fallen into disrepair.

\section{Photo 4. Two young men on their way to hunt while patrolling the area and boat}
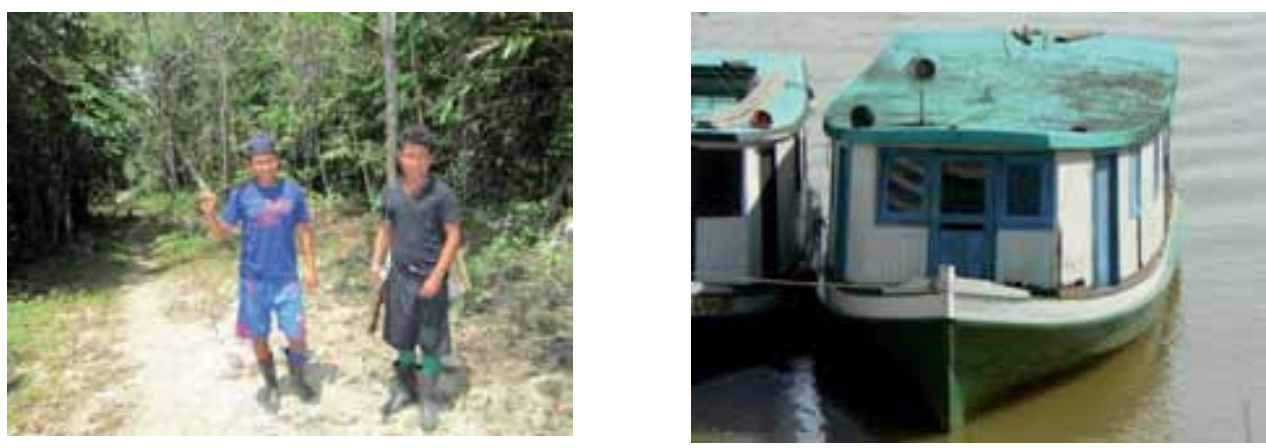

Credits: Silke Heuser and Roberto Maldonado

Overall the Indigenous Lands Project financed training sessions in more than 80 indigenous territories, conducted by 22 indigenous organizations and 3 NGOs (packaged in 36 contracts), to protect them from intruders through information campaigns in neighboring towns and through regular patrols. The hardware provided under the project, such as motors, boats, fuel, radios, etc. (about 25 percent of project costs), no longer functioned at the time that I visited the indigenous territories, which was four years after the end of the 15-year project implementation phase. Indigenous communities monitored the area only in those locations where FUNAI provided ongoing financial support. 
Conflicts with intruders or neighbors is the number one issue that kept coming up in conversations. This indicates that the indigenous communities are experiencing resource conflicts regularly.

Natural resource conflicts may involve illegal hunting, fishing, and mining, especially gold mining. It may also involve collecting Brazil nut ${ }^{41}$ and extracting wood illegally. According to the focus group discussion and newspaper articles, violent conflict exists between the Tenharim/Marmelos and the adjacent cattle farmers and loggers. The territory of the Tenharim/Marmelos is densely covered by rainforest.

However, just outside of the territory, I saw cattle pasture with a few scattered Brazil nut trees. White cows roam freely on the pasture. A bit further is the small town of Santo Antônio do Matupi at kilometer 180 on the Trans-Amazonian Highway with a population of about 12,000 people. This is also the heavily studied Manicoree region (also see Figure 14). The von Thünen model helps explain the tensions and resource conflicts that exist in this indigenous territory. The road, river, and small market center of Santo Antônio do Matupi all influence the value of the land and protecting it becomes even more difficult.

I saw five informal roads leading up to 100 kilometers into the rainforest and bordering several indigenous territories. I was informed that 32 sawmills existed along the road, five of them legal. I wanted to speak with the adjacent farmers but was informed by the FUNAI representative that this would be dangerous, even potentially life-threatening.

Indigenous territories are a form of protected area, a park with people. The indigenous peoples have the right to use trees and any natural resources above ground from the indigenous territories for their livelihood needs only. No commercial deals are allowed in these protected areas. Thus, only settlers from Santo Antônio do Matupi use the saw mills and transport the wood via the Trans-Amazonian Highway to the closest city and/or river port. Remote settlements in the Brazilian Amazon have a feel of the wild west. Law enforcement and the central government of Brasília are far away.

Newspaper articles say the following about violent conflict around the Tenharim/Marmelos:

\footnotetext{
${ }^{41}$ Índios do Médio Purus (AM) denunciam ameaça de pescadores e coletadores de castanha. Retrieved on March 22, 2017, from: https://terrasindigenas.org.br/pt-br/noticia/109176.
} 
"The south of the state of Amazonas is a region of tension and discrimination of nonindigenous people against indigenous people since the end of 2013. At the time, three non-indigenous men were killed, according to the Federal Police, by five Indians in the Tenharim Marmelos Indigenous Land." ${ }^{42}$

In a 2014 report by the Missionary Council for Indigenous Peoples (Conselho Indigenista Missionário, CIMI) provides a different view of the incident:

"In Amazonas, at the end of 2013, Chief Ivan Tenharim was found dead overnight at the Transamazon highway. After that, his successors, Gilvan and Gilson Tenharim and other three important indigenous leaders were accused of the murder of three people who were traveling through the highway, a known drug and gun smuggling route in the region. After some limited investigation, which was clearly rigged to put the blame on the indigenous, they were accused of collective vengeance for the supposed killing of the three non-indigenous individuals, whose bodies were found on Tenharim territory, to avenge the death of their chief." 43

In the case of the Tenharim/Marmelos, the demarcation and enforcement does not seem to be enough for the indigenous people to live their lives and preserve their culture. The rich natural resources in the area and the convenience of the Trans-Amazonian Highway create both a threat and an economic opportunity to the indigenous people of the Tenharim/Marmelos.

KfW Development Bank commissioned a paper analyzing whether demarcation reduced the incidence of land-related conflicts in indigenous lands. It found evidence that "demarcation reduced the incidence of land conflict among those communities supported early in the Indigenous Lands Project (Projeto Integrado de proteção ás Populações e Terras Indígenas da Amazônia Legal, PPTAL) project (between 1995 and 2003). The effect among later-supported communities was more variable and thus not statistically distinguishable" (BenYishay et al. 2016, p. 8).

\footnotetext{
${ }^{42}$ Retrieved on March 31, 2017, from https://terrasindigenas.org.br/pt-br/noticia/173471. Translated by Google Translate.

${ }^{43}$ CIMI. 2014. Violence against Indigenous Peoples in Brazil, 2014 Data. Brasília. Retrieved on March 31, 2017, from: http://www.cimi.org.br/File/Report\%20Violence.pdf.
} 
Indigenous territories belong to the Brazilian state. That means that FUNAI, the Ministry of the Environment, and IBAMA, are responsible for protecting the territories from intruders. Thus, the central government is responsible for confiscating illegally felled trees, capturing vehicles and chainsaws, and incarcerating and prosecuting offenders.

Since the government of Brazil and its institutions are far away, the Indigenous Lands Project introduced the innovation to have the indigenous communities monitor the area and inform FUNAI and the forest police about any offenders. During the trainings, the indigenous communities learned how to speak with their non-indigenous neighbors and teach them about the indigenous rights and develop preventive and protective measures against intruders, such as better presence along roads and rivers through strategic houses, monitoring missions, and radio communication.

In conclusion, based on my fieldwork, I was able to verify that demarcation and land titling took place in all four areas. I found evidence that the project provided training in monitoring and enforcement, although the equipment had fallen in disrepair by the time I visited the area. Patrolling took place only in those territories where FUNAI provided funding. However, resource conflicts with neighboring farmers, other tribes, and other rural people persist in all indigenous territories visited and are major concerns of the indigenous communities.

\subsubsection{Livelihood Basis Created}

The field visit to four indigenous territories showed me that indigenous territories have an important livelihood function for the indigenous peoples. Demarcation provides indigenous peoples with the right to use everything above ground for their consumption. This includes fish, game, agricultural products, and wood. As one focus group participant explained: "The land is our supermarket. Here we catch our fish, cultivate our vegetables, and hunt our meat." Thus, the Indigenous Lands Project directly supported the livelihood of the indigenous people.

According to the IBGE, the Paumari do Lago Marahã's monthly per capita income amounted to Reais 1,058 with 35 percent of people being without income. This income was above Brazil's monthly minimum wage in 2010 of Reais 506 (or USD268). In the Tenharim/Marmelos territory, the per capita income amounted to Reais 700, with 27 percent of people were without income. Interestingly, both per capita income as well as the percent of people without income were lower than in the Paumari do Lago Marahã territory, indicating that the income 
distribution was more equitable in the Tenharim/Marmelos territory. No information was available for the other two case study territories.

The focus group for the Tenharim/Marmelos community revealed three monetary sources of income. First, the Trans-Amazonian Highway cut through the middle of the indigenous territory. The Tenharim/Marmelos people had a rebellious history and fought hard against the road. It negotiated the agreement that every vehicle passing through the territory had to pay a toll. Smaller cars had to pay less than trucks. This toll enabled families to send their children off for higher education and increased the standard of living and well-being of the community. Every family took a turn collecting the toll for a month, so that all the families had to work for the money and ultimately benefited from the road. I visited the Tenharim/Marmelos on September 17, 2013. That day, the responsible family collected Reis 1,875 , corresponding to about USD600. The books at the toll station (a wooden pole across the road and a wooden shack) listed nine trucks loaded with felled trees. Trucks transporting wood had to pay Reis 70 (USD22) for the right to pass through the territory (see Photo 5). An income of USD600 on a random day of the year is a very large amount and is really bringing the indigenous people living along the Trans-Amazonian Highway into the modern economy and society, through education and hard cash. This was obvious during the field visit.

\section{Photo 5. Toll collection along the Trans-Amazonian Highway}

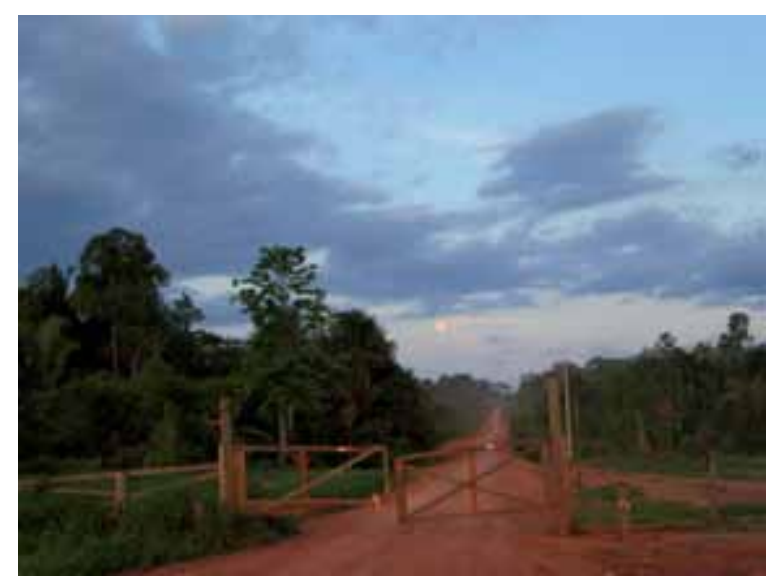

Credit: Silke Heuser

A second source of income was a tourism enterprise that took wealthy people on fishing expeditions in the middle of the Amazon. At the time, I did not ask for more detailed information on the marketing or websites of this tourism enterprise. However, according to the 
report, it was rather small scale for people wanting to experience the wilderness of the Brazilian Amazon.

A third source of income was social welfare payments that I will discuss in the next section.

The focus group for the Paumari do Lago Marahã community revealed, that not all members of the indigenous community were permanently living in the indigenous territory. For example, during the Indigenous Lands Project, one woman was allowed to go around with the team of experts in preparation for the demarcation. According to her, a woman in her village had never before been allowed to go so far afield. For her, it felt like new opportunities were opening up and she was able to see the lands from which her father and grandfather had told her in their stories, but which she was never allowed to see.

Subsequently, she was able to study and become a teacher in Lábrea, something that she attributed to the demarcation experience and to the contact with NGO representatives and technical experts. Since she was allowed to take trees from the indigenous lands, she was able to build a house in Lábrea. While she lived and worked in the city, she was still closely connected to the indigenous territory in terms of resource use and cultural identity.

This indigenous territory of Paumari do Lago Marahã does not necessarily correspond to my expectations informed by the von Thünen theory, especially when it comes to incomes. The territory is inaccessible and only connected with a small town via a waterway. With respect to income level, the territory is an outlier, but not with some other indicators, such as wooden houses and education levels. To my knowledge, the high-income level can be best explained by migration.

A life in between rural and urban settings is a pattern described as typical for the Brazilian Amazon region for indigenous and non-indigenous people alike. Indigenous people may work in a close-by city and come back to the indigenous lands on occasion to visit family and to collect nuts and other natural resources. Trade, remittances, and cultural exchange benefit both those who stay and those who leave (Padoch et al. 2008). Padoch et al. (2008) describe this model of living in between rural and urban settings as typical for the Amazon. The families' off-farm income results from circular migration. Three of the four case studies reported receiving income from circular migration. 
Another sign of the difference between life in indigenous territories among outside indigenous territories became evident from visiting the Diahui. Focus group participants spoke about the dire conditions of those Diahui who had left their territory because they had been evicted by a cattle farmer. Families had fallen into poverty, unable to make a living in the slums of larger cities. As soon as they learned about the demarcation process they returned to their original lands and built a new settlement, called Kwari. More Diahui members were still expected to return at the time I was visiting.

\section{Photo 6. Traditional meeting room of the Diahui}

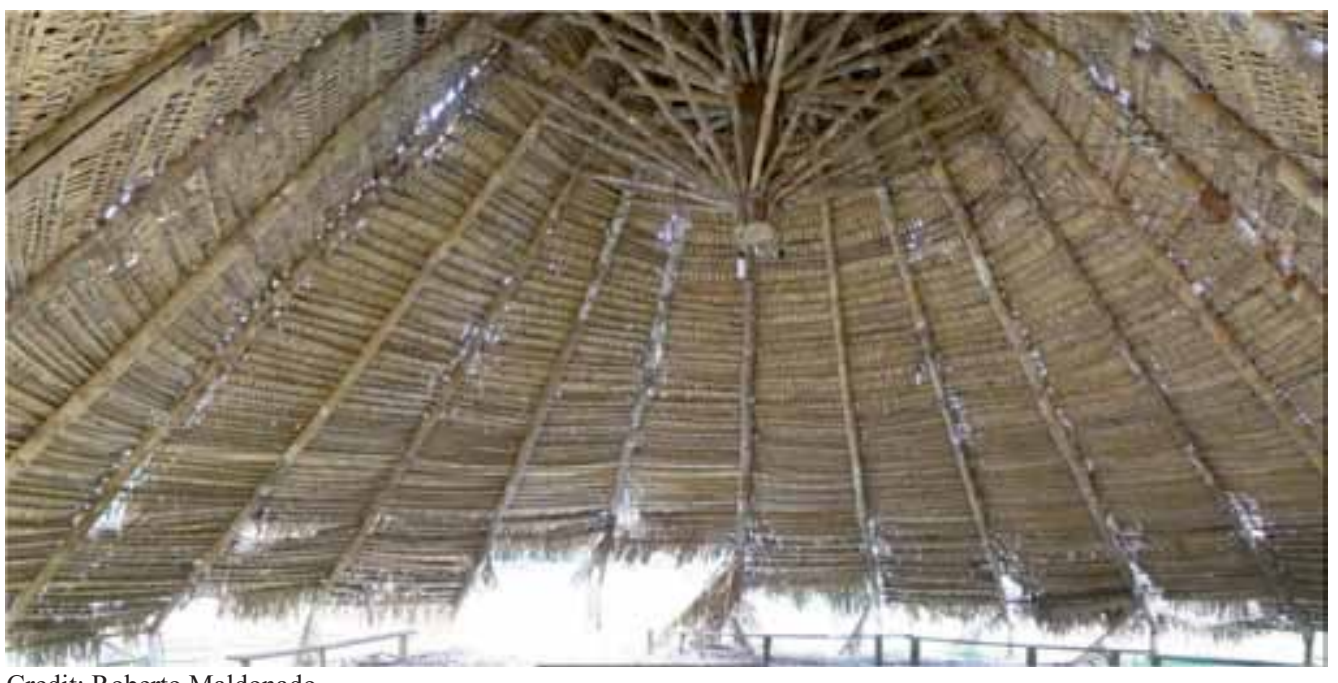

Credit: Roberto Maldonado

In the way the Diahui dressed and constructed their houses, this indigenous community seemed the most traditional of the four communities visited (Photo 6). This is remarkable, since the Diahui had lost their land and traditions at some point and were assimilated into the broader Brazilian society. Like the Tanharim/Marmelos the Trans-Amazonian Highway crossed their territory, which may increase the value of the land, according to von Thünen. However, due to eviction and return migration to their ancestral lands, the Diahui seemed to value their regained traditions, livelihoods, and lands the most compared with the other three communities.

Brazil has a pension system with social assistance payments to the elderly and disabled who are not able to work. ${ }^{44}$ According to Berg-Nordlie et al. (2016), indigenous peoples "left their

\footnotetext{
${ }^{44} \mathrm{http}: / /$ thebrazilbusiness.com/article/brazilian-pension-system.
} 
semi-nomadic way of life and settled down in permanent villages, due to their dependence on services from outside, in education, health, pensions and transport, and in order to get access to markets and other modern urban services.” During my field visit, focus group participants valued the pension system. However, accessing these funds is not always easy.

The indigenous territories are often remote and therefore transportation costs are high. Given that social welfare payments need to be collected in urban centers, people tend to spend it on in towns, bringing home sodas and other food items that change traditional food consumption patterns.

Bolsa Família is a large social welfare program in Brazil, introduced in 2003 as a follow-on program to Bolsa Escuela. Bolsa Família provides conditional cash transfers to poor families, preferably mothers on the condition that they send their children to school, have them vaccinated and attend regular health check-ups. Brazil-wide, about a quarter of its population receives Bolsa Família assistance and the program has reduced Brazil's poverty rate, lifting millions out of poverty (Sanchez-Ancochea and Mattei 2011).

According to Sanchez-Ancochea and Mattei, "the proportion of people in poverty decreased in Brazil by 44 percent between 1990 and 2009 with most of the reduction taking place between 2002 and 2009 after Bolsa Família was introduced and economic growth accelerated. Poverty rates went down faster than in the rest of Latin America, particularly after the global financial crisis" (p. 306).

The program pays monthly stipends of about USD22 per child. A World Bank-funded project assisted in registering indigenous and other minority representatives into the program. According to the World Bank's 2010 appraisal document, an earlier phase of the project increased the number of indigenous program beneficiaries "from 29,000 in March 2006 to 71,000 in January 2009, of which 59,000 were program beneficiaries" (World Bank Group 2010 , p. 3). The program is said to have increase political participation and empowerment, especially among female beneficiaries. However, negative aspects exist as well, such as high transport costs and changing consumption patterns mentioned earlier.

Here I would argue that the demarcation of indigenous territories helped the process of pension and conditional cash payments. Demarcating an indigenous territory and providing it with GPS coordinates on a map and a community land title enters it in the government's official registry and help register beneficiaries who before did not have an address or location. The effect of 
demarcation can be compared to slum upgrading in urban centers, which had a similar effect, according to the World Bank. ${ }^{45}$

Another question is, were indigenous communities confined to their territories and, if so, did this confinement actually benefit their livelihood? From my observations, at the time of the field visit, people in the indigenous territories seemed content with their status, their lands, and their livelihood. I would argue that the indigenous territories and the associated land-use rights enabled the indigenous communities to pursue their traditional livelihoods of shifting cultivation, hunting, and gathering, in addition to new livelihoods, such as toll collection, tourist guides, employees of FUNAI, teachers, and doctors.

In addition, the Brazilian state supported poor families through welfare payments. Even though indigenous land titles define strict borders and may eventually become too small to support a growing population, they do not restrict movement to urban centers. Instead, they create a livelihood basis for those indigenous communities that chose a more traditional life and livelihood.

The next section will explore service provision by the Brazilian government in indigenous territories of the Brazilian state of Amazonas.

\subsubsection{Level of Basic Services}

Income is just one indication of wealth and well-being, especially in remote areas, such as indigenous territories in the Brazilian Amazon forest. During my field visit to the four indigenous territories I noticed that in three indigenous communities, houses were made from wood, whereas one community, the one located along the Trans-Amazonian Highway in proximity to the small town had houses made from brick, which is explained by the von Thünen model. Communities had access to some form of electricity, and those along the TransAmazonian Highway had access to the internet. In addition, the communities I visited had

\footnotetext{
${ }^{45}$ According to Parker (1999), "where urban amenities lead to great improvements in living conditions, an unanticipated benefit was that it led to the development of addresses. That is, as roads and paths improved they received names and numbers, and condominium members received identifiable house numbers. [...] Self-esteem [increased] from becoming a recognizable member of society. Many families showed [...] their water bills, proud that for the first time their government knows who they are, and they have their own place in society. While many people had argued that slum dwellers (favelados) would not pay for services, that prediction has not been justified by the project experience."
} 
access to an improved source of water and pit latrines, but no garbage collection system. Garbage was buried or burned.

In all four communities, I saw a school with TV, and a basic health clinic. For example, on the day of my visit to the indigenous territory of the Tenharim/Marmelos, a visiting dentist from Peru was checking the children's teeth on a pro bono basis. According to a national health survey from 2013, indigenous communities in the North of Brazil tend to have the poorest garbage disposal and sanitary conditions, the lowest access to electricity, mostly wooden houses, and the poorest health among women and children as compared with indigenous communities in other regions (Coimbra et al. 2013).

According to Le Tourneau (2015), "As a result of these flaws, the social situation is in general very difficult inside the Indigenous territories of the Amazon. Health and social indices are among the worst in Brazil: infant mortality rate is much higher than the national, tuberculosis or malaria prevalence are extremely high $(34,35)$, nutrition problems are commons and alcoholism, or suicide are widespread. Indigenous peoples must always keep a political pressure on the federal government (for instance by invading regional offices of the health administration) in order to be granted the necessary" (p. 8).

A different study finds some improvements in the health of young women living in rural areas in the North. According to Borges et al. (2016), "the increase in very young adolescent fertility rate in Amazonas can be partly attributed to improvements in vital statistics notifications observed in the state and in the entire Northern region in the last decades, even though birth underreporting still occurs" (p. 7).

Findings from the national health survey clearly point to a trade-off for the indigenous communities voting for a life in the indigenous territories. Both child-mortality rates, as well as maternal mortality are higher in rural areas as compared with urban centers, but comparable for indigenous and non-indigenous people (UNICEF 2012). The more recent study by Borges, note some health improvements in recent years.

In terms of literacy levels and according to IBGE's 2010 census, 63 percent of the Tenharim/Marmelos were literate compared with 40 percent among the more remote the Paumari do Lago Marahã. According to UNESCO, school attendance among the 15 to 17 -yearold indigenous population increased by 22.4 percent, from a low of $74.1 \mathrm{in} 2004$ to a high of 90.7 percent in 2012 (UNESCO 2015). This is in line with the von Thünen model, which 
explains that the more accessible areas would have better literacy levels, which is the case among my four case studies.

\subsubsection{Do Indigenous Peoples Actually Live in Indigenous Territories?}

Comparing population growth among the indigenous population living in indigenous territories proved challenging due to the way, the Brazilian Institute of Geography and Statistics (IBGE) collected data on ethnicity in the past. Below I use triangulation to arrive at an estimate to what extend indigenous peoples live in indigenous territories and how these trends have evolved over time.

IBGE included the category of "indigenous" as part of the question on color or race starting in the 1990s. In 2010, IBGE introduced a category for indigenous peoples to self-identify as indigenous (Bastos et al. 2017). This led to data on indigenous population being available at different levels. For the years 1991 and 2000, data on indigenous ethnicity are available only in aggregated form by broad geographic area (such as the North, or North-East where most of the indigenous territories are situated), and by the category of urban versus rural. For the census of 2010, data are available by indigenous territory, a much more granular categorization.

In order to examine population growth across time, this section needs to rely on the broad regions for the years 1991, 2000, and 2010. I triangulated these data with a sketchy dataset where I compiled data from FUNAI's Indigenous Lands database for some of the indigenous territories demarcated under the Indigenous Lands Project, the ISA database that lists population data from various sources, and IBGE (Figure 15). This is the closest proxy available for population data in the indigenous territories. Furthermore, I looked at population pyramids in order to take stock of what the population distributions between indigenous and nonindigenous communities looked like as of the 2010 IBGE census for Brazil as a whole, at the broad regional level as well as indigenous community level for three of the four case study communities where data were available.

As stated earlier, the IBGE records self-declared ethnicity in its 2010 census (Bastos et al. 2017). ${ }^{46}$ While this is not an objective measure, it can be considered a proxy for the number of

\footnotetext{
${ }^{46}$ IBGE introduced a question of self-declaration as indigenous in its 2010 census compared to the earlier census of 1991 and 2000 where the census covered indigenous people under race. Retrieved on April 28, 2018, from: https://indigenas.ibge.gov.br/graficos-e-tabelas-2.html.
} 
indigenous people in Brazil. This number also hides Brazil's large number of mixed ethnicity. Mixed race or Pardo Brazilians account for about 43 percent, or 82.3 million of Brazil's population. ${ }^{47}$ According to the IBGE (2012, p. 12), 817,963 people declare themselves indigenous, compared with 294,131 in 1991 and 734,127 in 2000. As of 2010, a total number of 305,873 self-declared indigenous people live in Brazil's Northern region (mostly the Legal Amazon), compared with 124,615 in 1991 and 213,443 in 2000.

Population pyramids for the whole indigenous population of Brazil compared with the Northern region show a young population with a broad base for the Northern region, in which most of the indigenous territories demarcated under the Indigenous Lands Project are located (Figure 12). Overall the age distribution did not change much between the census in 1991, in 2000 and in $2010 .^{48}$

Figure 12. Population pyramids for indigenous people in Brazil and the Northern region

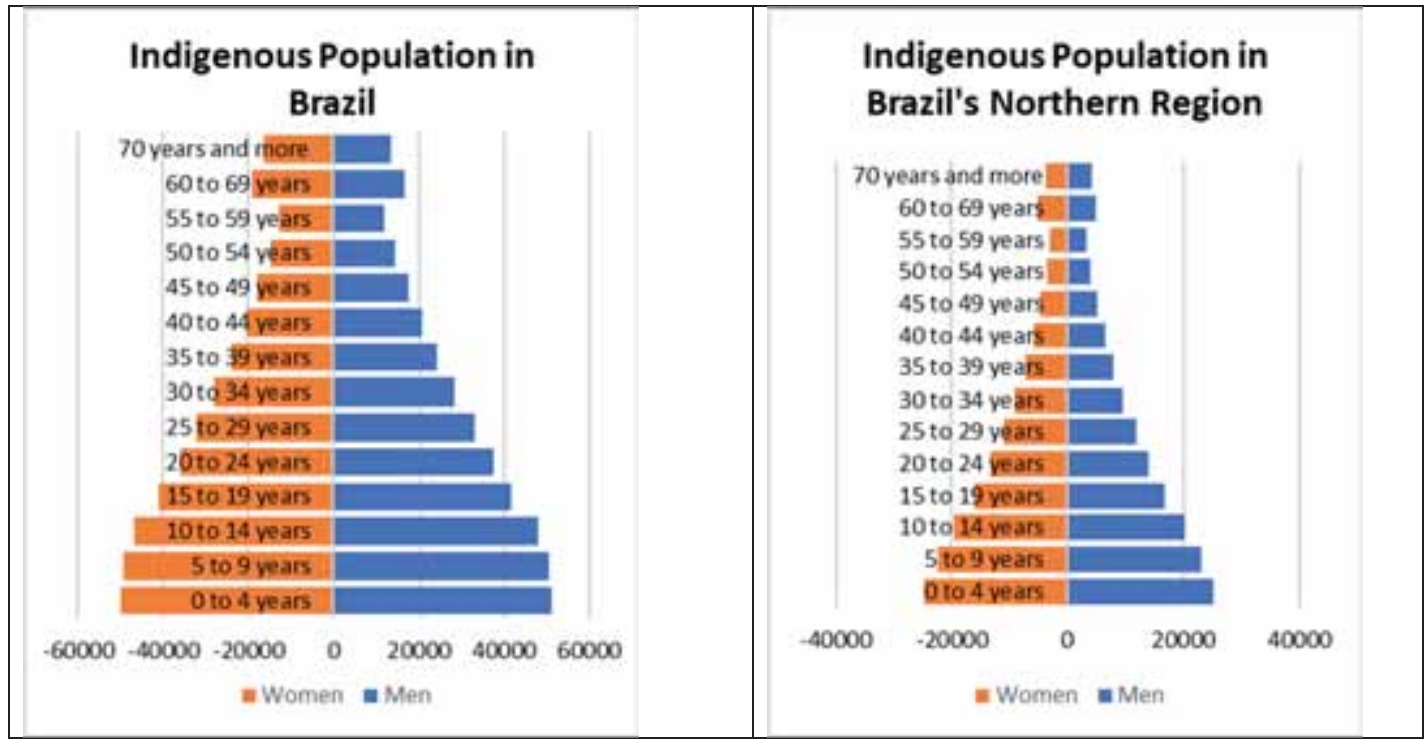

Source: IBGE 2010, Table 1.3.1 and Table 2.1.3.1.

The left side in Figure 13 below shows a population pyramid for indigenous people living in indigenous areas in Brazil's Northern region. Comparison of the pyramid for all indigenous

\footnotetext{
${ }^{47}$ Retrieved on June 25, 2017, from: https://en.wikipedia.org/wiki/Demographics_of_Brazil.

${ }^{48}$ See the following IBGE, Indígenas website for an interactive pyramid for the census in 1991, 2000, and 2010) and the different regions of Brazil. Retrieved on April 28, 2018, from: https://indigenas.ibge.gov.br/piramideetaria-2.html.
} 
people in the Northern region (Figure 12 on the right) and that of indigenous people living in indigenous areas (Figure 13 on the left), it is evident that the number of people under the age of 15 is even higher in indigenous territories.

This becomes even more obvious if the 248,883 indigenous people residing in indigenous territories is subtracted from the total indigenous population in Brazil's Northern region of 305,873 . Those living outside the indigenous territories represent only 56,990 indigenous people, or 19 percent of the total indigenous population residing in indigenous territories in Brazil's Northern region. Figure 13 on the right representing the Northern region outside of indigenous lands also indicates fewer young children and more female representation in the age range above 10 to 14 years. Further, the population above 60 years of age is relatively higher, which can be explained by the incentive created by Brazil's pension system for indigenous people to live closer to an urban area.

Figure 13. Population pyramids for indigenous people in the Northern region living in indigenous territories compared with those living outside indigenous territories

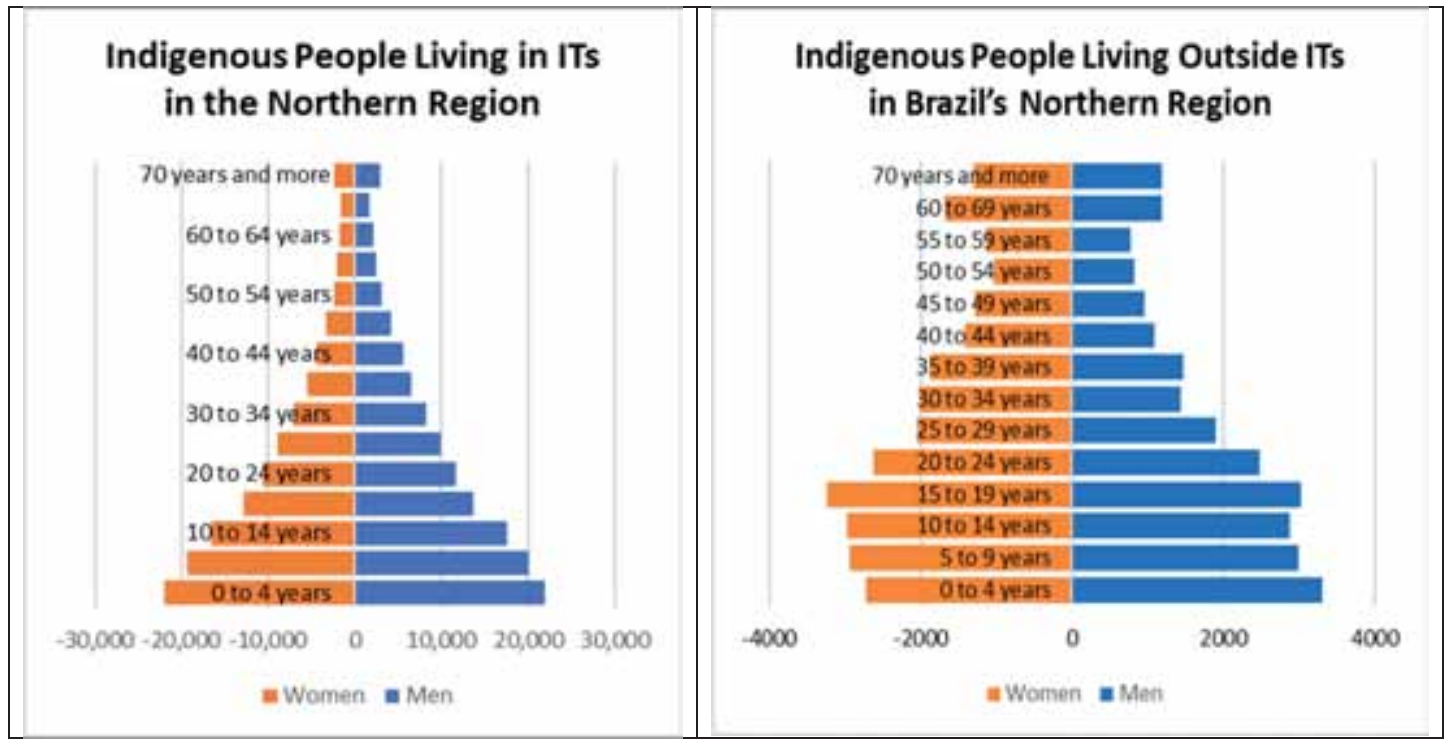

Source: IBGE 2010, Table 2.1.3.1. and Table 3.4.5.2.

Findings are quite different for the non-indigenous population. Population pyramids for the non-indigenous population of Brazil compared with that for the Northern region shows fewer young children both in the Northern region and in all of Brazil (Figure 14). 
Figure 14. Population pyramids for non-indigenous people in Brazil and the Northern region

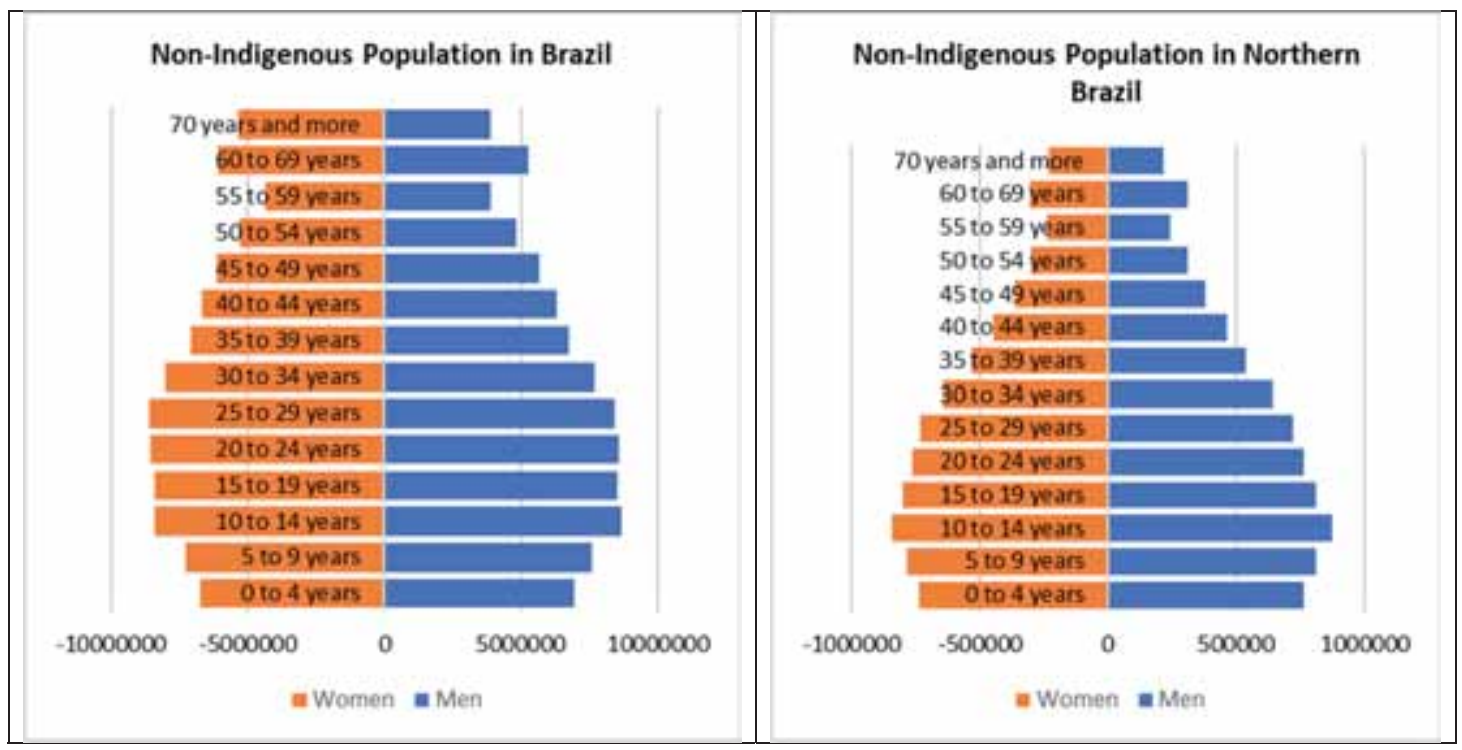

Source: Source: IBGE 2010, Table 1.3.1 and Table 2.1.3.1.

For a better understanding of population growth among indigenous peoples in the Northern region of Brazil, fertility, mortality, and migration rates are relevant. Brazil's 2010 census only offers mortality rates for children under the age of 1 . I therefore, rely on the literature to fill in data gaps.

According to the IBGE, fertility appears to have slowed when looking at the national level but has remained high in the Northern region. According to the IBGE, fertility rates fell from 2.38 children per woman in 2000 to 1.86 children per woman in 2010 for Brazil as a whole. In the North, fertility was high and increased between 2000 and 2010. According to Borges et al. (2017), for example, fertility amounted to 5.46 live births per 1,000 in 2000, compared with 5.85 in 2010 among adolescents between the age of 10 and 14 in the North. In the state of Amazonas, fertility was even higher and increased between 2000 and 2010 from an average of 5.57 live births per 1,000 to 7.05 (Borges et al. 2017). Remember that declining fertility does not immediately give rise to declining populations. Among the indigenous groups outside the North, fertility has declined, although the population is still growing. In the North of Brazil, fertility among the indigenous groups is still high, with overall high rates of population growth.

A similar pattern applies to infant mortality. While Brazil was able to reduce infant mortality during the last decade, it still is relatively high in the Northern and Northeastern regions and 
among the rural indigenous population. According to UNICEF, the infant mortality rate among the indigenous populations amounted to 41.9 per 1,000 live births, twice as high as the national rate. $^{49}$ As for maternal mortality, Brazil was able to reduce maternal mortality among indigenous people, but mortality stays relatively high in Brazil's rural North as compared with Brazil's southern regions. According to UNICEF, "a maternal mortality survey taken in all state capitals in 2010 estimated the maternal mortality rate in Brazil to be an average of 54.3 deaths per 100,000 live births, a number that ranged from 42 in the south to 73 in the northeast." In addition, "despite progress in maternal health, $[\ldots]$ a three-quarters reduction in maternal mortality remains unlikely, although the maternal mortality ratio has dropped by almost half since 1990, from 140 to 75 deaths per 100,000 live births. While fertility rates have decreased steadily for all age groups, the number of pregnancies among girls aged 10 to 14 has slightly increased in recent years. The number of infants born to mothers under 15 went up from 6.9 per 1,000 live births in 1994 to 9.7 in 2007. Birth registration has increased but remains low in the North and North-East regions, especially in the Amazon and semi-arid areas and among indigenous populations." 50

In terms of migration, the indigenous population living in indigenous territories in Brazil's North followed a pattern of the rural population in this region. Overall, the migration rate was low. In 2010, about 1 percent worked or studied in another municipality in the same state and 0.001 percent of the indigenous and rural population lived in a different state. Only 61 people lived abroad. ${ }^{51}$

The focus group discussions revealed some form of mobility in all four case study indigenous communities (Table 9). Focus group participants in the Paumari do Lago Marahã and Tenharim/Marmelos indigenous territories referred to circular migration, or a life in between rural and urban settings for indigenous people working in the close-by city. Average per capita income from the 2010 census confirms a relatively high income for a remote rural area of Reis 1,058 for the Paumari do Lago Marahã and Reis 700 for the Tenharim/Marmelos, well above

\footnotetext{
${ }^{49}$ Retrieved on April 28, 2018, from:

https://www.unicef.org/about/execboard/files/Brazil_final_approved_2012-2016_English_10Feb2012_.pdf.

${ }^{50}$ Retrieved on April 28, 2018, from:

https://www.unicef.org/about/execboard/files/Brazil_final_approved_2012-2016_English_10Feb2012_.pdf.

${ }^{51}$ IBGE 2010: Tabela 1.13 - População residente autodeclarada indígena, por deslocamento para trabalho ou studo, segundo a situação do domicílio e o sexo - Brasil.
} 
Brazil's monthly minimum wage of Reis 505.90 (USD267.81) in 2010. ${ }^{52}$ The indigenous territory of the Diahui had experienced almost total eviction from their territory during the 1990s.

Table 9. Comparing migration movements among the different indigenous communities

\begin{tabular}{|c|c|c|c|c|}
\hline No. & Name & $\begin{array}{l}\text { Circular } \\
\text { migration }\end{array}$ & $\begin{array}{l}\text { Return } \\
\text { migration }\end{array}$ & $\begin{array}{l}\text { Possible marriage-related } \\
\text { migration among women }\end{array}$ \\
\hline 1 & Paumari do Lago Marahã & Yes & No & Yes \\
\hline 2 & $\begin{array}{l}\text { Jarawara / Jamamadi / } \\
\text { Kanamati }\end{array}$ & No & No & Yes \\
\hline 3 & Tenharim/Marmelos & Yes & No & Yes \\
\hline 4 & Diahui & No & Yes & No data \\
\hline
\end{tabular}

Source: FUNAI database, focus group results, ISA https:/terrasindigenas.org.br/pt-br/terras-indigenas/

A third factor of mobility was marriage. Comparison of the gender-disaggregated data in the population pyramids reveals that, especially in the age range of 15 to 25 , there are fewer women compared to men in all four indigenous territories. This is an indication of either maternal mortality, or that girls have either been sent off to study, as in the case of the Tenharim/Marmelos (where a girl studied medicine in Cuba), or marriage to a husband in a different indigenous territory, village, or city.

These general migration trends noticed in the four case studies can be confirmed by looking at the countrywide data for indigenous people. According to the IBGE census, there were a total of 734,127 self-declared indigenous people living in Brazil. ${ }^{53}$ Of those, 304,324, or 41 percent lived in indigenous territories. According to the 2010 census, one percent of indigenous people living in indigenous territories, or 3,429 people migrate for work or study to another municipality (2,627 men, and 801 women). In addition, 365 work or study in another state, and 61 work or study abroad. ${ }^{54}$ Given the remoteness of the indigenous territories, these numbers are high. They do not capture return migration, however.

\footnotetext{
${ }^{52}$ Retrieved on April 10, 2018, from: http://www.reuters.com/article/brazil-economy-wageidUSN3145544020090831.

${ }^{53}$ IBGE 2010. Tabela 1.1 - População residente, por cor ou raça, segundo a situação do domicílio; e os grupos de idade - Brasil.

${ }^{54}$ IBGE. 2010. Tabela 1.13 - População residente autodeclarada indígena, por deslocamento para trabalho ou estudo, segundo a situação do domicílio e o sexo - Brasil.
} 
Population growth of indigenous peoples in the Northern regions of Brazil can be determined based on the IBGE census data from 1991, 2000, and 2010. According to a 2012 publication ${ }^{55}$ by IBGE, the Brazilian census bureau, a large growth increase occurred among indigenous people between 1990 and 2000 (Table 10), but not in the later period of 2000 to 2010. This earlier increase can likely be attributed to a change in self-declaration of "indigenous" rather than high birth rates (IBGE 2012).

Table 10. Average annual population growth rates for indigenous and non-indigenous people living in urban versus rural areas, 1991/2000 and 2000/2010

\begin{tabular}{|l|c|c|}
\hline \multicolumn{1}{|c|}{$\begin{array}{c}1991 / 2000 \\
\text { Residence and race }\end{array}$} & $\begin{array}{c}2000 / 2010 \\
\text { Percent of average annual } \\
\text { population growth rates }\end{array}$ \\
\hline Indigenous & 10.8 & 1.2 \\
\hline Non-indigenous & 1.6 & 1.1 \\
\hline Urban & 2.5 & 1.6 \\
\hline Indigenous & 20.8 & $(-) 1.9$ \\
\hline Non-indigenous & 2.4 & 1.6 \\
\hline Rural & $(-) 1.3$ & $(-) 0.7$ \\
\hline Indigenous & 5.2 & 3.7 \\
\hline Non-indigenous & $(-) 1.4$ & $(-) 0.7$ \\
\hline
\end{tabular}

Source: IBGE 2012. Os Indigenas no Censo Demográfico 2010 primeiras considerações com base no quesito cor ou raça. Rio de Jeneiro, Table 2.

More specifically, annual population growth in Brazil's rural North amounted to 4.5 percent during the 1990 and slightly decreased to 3.9 percent during the 2000 decade and only topped by the North-East that encountered annual population growth of indigenous people living in indigenous territories of 4.7 percent. ${ }^{56}$ Population growth was negative in Brazil's south and south-east regions (IBGE Indígena and Bastos et al 2017). I would like to draw special attention

\footnotetext{
${ }^{55}$ According to the IBGE the large increase in self-declared indigenous can be noticed between 1991 and 2000, but not in the later period: "Em 2000, as autodeclarações indígenas aumentaram substancialmente em relação a 1991, enquanto, em 2010, mantiveram-se em patamares similares.” IBGE. 2012. Os indígenas no Censo Demográfico 2010 primeiras considerações com base no quesito cor ou raça. Rio de Jeneiro.

${ }^{56}$ Retrieved on April 27, 2018, from:

https://indigenas.ibge.gov.br/images/indigenas/estudos/indigena_censo2010.pdf.
} 
to the fact that the majority of indigenous people living in rural areas live in indigenous territories and that population growth there was above average.

For the indigenous lands demarcated under the Indigenous Lands Projects, I compiled population information for the years 2000 to $2010 .{ }^{57}$ I found population information for a total of 128 indigenous lands in these indigenous territories. Overall, I found more indigenous people living in 107 indigenous territories for which information was available, while fewer people were living in 21 indigenous territories over the 10 -year period.

When I looked at the specific location of the indigenous territories I saw that 17 of the 21 indigenous territories that had fewer people living there in 2010 compared to 2000 (or earlier) were in very remote locations or even bordering neighboring Peru, Colombia, Venezuela, or Guyana. Two were very close to a major city, and two were outliers (Batelao and Arary). The location of these territories is in line with the von Thünen model, which could explain that places along the border with no river or road to connect to a market center would become less populated and attractive because of lower revenues from agricultural products. In addition, indigenous territories very close to an urban center may be more prone to migration to cities and to losing their identity.

According to the data, the annual population growth rate amounted to 3 percent for the period from 1992 to 2000 and 4 percent for the period from 2000 to $2010 .^{58}$ These numbers indicate that more indigenous people lived in indigenous territories in 2010 as compared with 1991 and $2000 .{ }^{59}$ Figure 15 shows the number of indigenous people per territory in the indigenous lands dataset, ISA, and IBGE information for all those territories where information was available.

\footnotetext{
${ }^{57}$ IBGE, FUNAI, and ISA.

${ }^{58}$ I calculated the annual population growth rate using the following online calculator: Retrieve on April 29, 2018, from http://www.endmemo.com/algebra/populationgrowth.php. Also see Schmidt and Terberger (1997, p.127f).
}

${ }^{59}$ A 2012 IBGE study on indigenous people indicated an average annual population growth rate for indigenous people living in rural areas across all of Brazil of 3.7 percent IBGE. 2012. Os indígenas no Censo Demográfico 2010 primeiras considerações com base no quesito cor ou raça. Rio de Jeneiro. 
Figure 15. Number of indigenous people living in indigenous territories demarcated under the Indigenous Lands Project

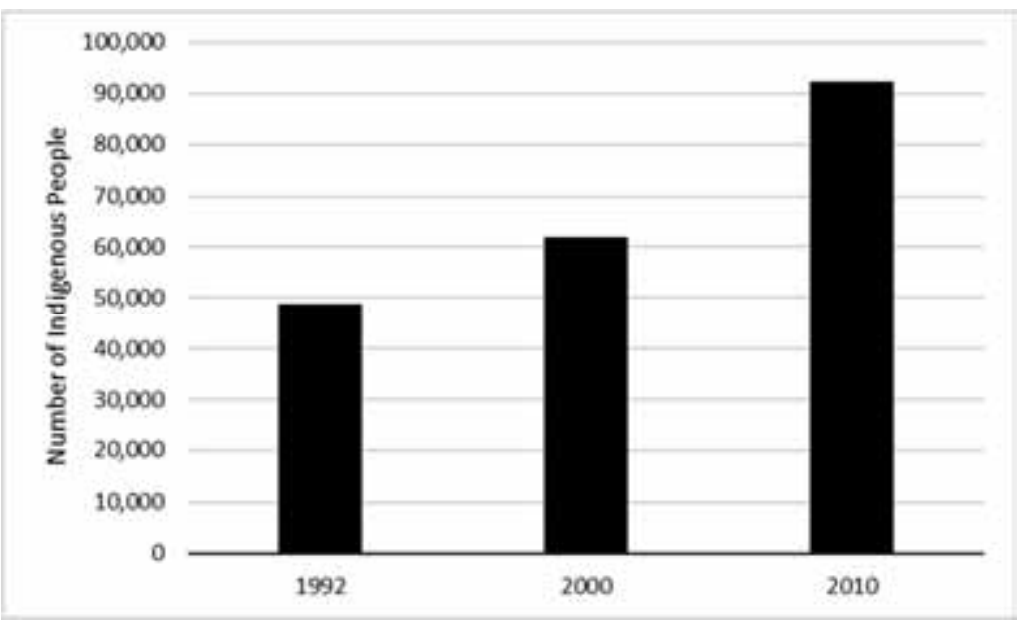

Source: FUNAI database, ISA, IBGE

The different information from the Indigenous Lands Project, the IBGE, and ISA data show that more people live in indigenous territories as compared to the 1990s. Unfortunately, the IBGE provides information about individual indigenous territories only for 2010, not for earlier years. Therefore, it is not possible to draw conclusions about population growth at the more granular level of the indigenous territories. However, the strong population growth that I saw in Brazil's rural north speaks to the turnaround highlighted in the literature (McSweeney and Arps 2005), that there was a recent increase in the population growth among the indigenous population in Brazil in general, and in the Brazilian Amazon in particular.

With respect to my research question about the survival of indigenous peoples in indigenous territories, I found the following. Population growth in 128 indigenous territories demarcated by the Indigenous Lands Project amounted to a yearly average of 4 percent for the years 2000 to 2010, which is much higher than Brazil's average population growth rate of 0.75 percent. 
Table 11. Population growth of indigenous people in case study indigenous lands

\begin{tabular}{|l|l|l|l|}
\hline Name & $\begin{array}{l}\text { Number of people } \\
\text { in } 1996\end{array}$ & $\begin{array}{l}\text { Number of people } \\
\text { in } 2010\end{array}$ & $\begin{array}{l}\text { Average growth } \\
\text { rate }\end{array}$ \\
\hline Paumari do Lago Marahã & 561 & 1,076 & $4.7 \%$ \\
\hline Jarawara/ Jamamadi/ Kanamati & 400 & 527 & $2.0 \%$ \\
\hline Tenharim/ Marmelos & 393 & 535 & $2.2 \%$ \\
\hline Diahui & 17 & 77 & $10.8 \%$ \\
\hline
\end{tabular}

Source: FUNAI and project documents

When I compare the population growth rate in the four case study indigenous communities (Table 11), I find that population growth ranged from a low of 2 percent to a high of 10.8 percent due to return migration, with an average of 5 percent annual population growth for the years 1992 to 2010. Here as well, annual average population growth rates are higher in indigenous territories than the Brazilian average of 0.75 percent.

The population distribution by sex for the year 2010 from the IBGE shows a broad base and a classic form of the population distribution. The IBGE does not provide information for all the ages. It provides five-year steps up to the age of 14, lumps ages 15 to 24 together and provides population results for the years 25 to 49 and above 50 (Figure 12). This is the reason I present the data in the form of a table and not a pyramid.

Figure 12 indicates that all three indigenous communities (for which data were available) had a population distribution with a broad base and a large young population. A surprising finding is the gender imbalance from the age of 15 years and above (with gender imbalance of 14, 8, and 18 fewer women than men). This could be explained by high mortality rates during child birth, education in nearby urban centers, or marriage to a different tribe. One of the focus group discussions revealed, for example, that one family had been sending their daughter to Cuba to become a medical doctor, return and improve the health situation of the extended family. 
Table 12. Population distribution by gender for three indigenous territories

\begin{tabular}{|c|c|c|c|}
\hline Age & Men & Women & Gender Imbalance \\
\hline \multicolumn{4}{|c|}{ Paumari do Lago Marahã — AM } \\
\hline 0 to 4 years & 98 & 99 & -1 \\
\hline 5 to 9 years & 99 & 77 & 22 \\
\hline 10 to 14 years & 62 & 59 & 3 \\
\hline 15 to 24 years & 105 & 91 & 14 \\
\hline 25 to 49 years & 119 & 102 & 17 \\
\hline 50 years and more & 58 & 46 & 12 \\
\hline \multicolumn{4}{|c|}{ Jarawara/Jamamadi/Kanamati_-AM } \\
\hline 0 to 4 years & 38 & 36 & 2 \\
\hline 5 to 9 years & 31 & 40 & -9 \\
\hline 10 to 14 years & 28 & 29 & -1 \\
\hline 15 to 24 years & 56 & 48 & 8 \\
\hline 25 to 49 years & 72 & 60 & 12 \\
\hline 50 years and more & 48 & 41 & 7 \\
\hline \multicolumn{4}{|c|}{ Tenharim Marmelos-AM } \\
\hline 0 to 4 years & 34 & 29 & 5 \\
\hline 5 to 9 years & 40 & 49 & -9 \\
\hline 10 to 14 years & 49 & 49 & 0 \\
\hline 15 to 24 years & 89 & 71 & 18 \\
\hline 25 to 49 years & 93 & 97 & -4 \\
\hline 50 years and more & 33 & 30 & 3 \\
\hline
\end{tabular}

Source: IBGE 2010, Tabela 3476 - Pessoas residentes em terras indigenas, total e indigenas, por sexo e grupos de idade, segundo as Terras Indigenas.

\subsection{DISCUSSION AND POLICY IMPLICATIONS}

The main policy issue related to the indigenous peoples of Brazil involves the future sustainability of their populations. Overall, indigenous people represent 0.4 percent of the population and have exclusive land-use rights to more than 20 percent of the forest. The policy alternatives are either to preserve and protect the status quo or provide indigenous peoples with an alternative livelihood. Thus, this section will discuss policy options for the Brazilian government.

Despite the dark history of indigenous relations in Brazil, the outlook for their communities today is relatively optimistic given the strong population growth and considerable well-being of the indigenous communities. However, the outlook is less optimistic with respect to some new 
threats. Some new threats confronting the indigenous territories are similar to those they have endured since the beginning of Brazil's settlement policy in the 1970s. Other threats are more recent in nature.

All four territories visited face some external threat. The Paumari do Lago Marahã compete for resources with other indigenous tribes and with intruders from the nearby mine among others. The Jarawara/Jamamadi/Kanamati compete for resources with the extractive reserve in its vicinity. Resource conflicts are strongest for the Tenharim/Marmelos, given the presence of the Trans-Amazonian Highway in their territory, the large cattle farm nearby, and the proximity of a deforestation hotspot where illegal forest roads reach far inland. The Diahui faced the most radical resource competition in the past by being almost completely evicted from their territory. With demarcation and a legal title to their lands, however, resource competition has diminished somewhat, even with the Trans-Amazonian Highway cutting through the territory.

Despite some local monitoring and enforcement activities under the Indigenous Lands Project, deforestation occurred to some extent in three of the four indigenous territories between 2000 and 2010. The largest area deforested in that period was in the Paumari do Lago Marahã territory ( 0.9 percent) followed by the Jarawara/Jamamadi/Kanamati ( 0.8 percent), the Tenharim/Marmelos territory ( 0.5 percent), and finally the Diahui that had encountered large deforestation before 2000, but no deforestation after.

The policy environment in Brazil seems to be shifting between two extremes. On the one hand, the government supports the settlement policy of the Brazilian Amazon, and on the other hand it preserves the Brazilian rainforest through various protected areas and reserves, one type of which is the indigenous territories.

Thus, the indigenous communities living in the demarcated areas are constantly confronted by resource conflicts between cattle farmers, wood cutters, and mineral extraction enterprises. Indigenous communities are also threatened by the construction of large dams, which alter the water table and, with it, fish resources and environmental services. Roads and urban sprawl are also a threat to these communities.

Yet another threat is climate change and changing weather patterns. The indigenous lands experienced unusually high heat waves, forest fires, and flooding that can be attributed to El Niño. Furthermore, some research has found increasing severity of these natural hazards linked to climate change (Malhi et al. 2008). 
The IPCC refers to the Amazon region as a well-researched climate change hotspot, especially responsive to global change (IPCC 2014, Part B). According to the report, the Amazon region is particularly vulnerable to changes in mean and inter-annual variability of temperature and precipitation, as well as seasonal extremes. For example, Donat et al. (2013) find more frequent and intense rainfall in Amazônia.

According to projections, droughts will likely intensify in Amazônia in the future, due to decreasing precipitation and increased evapotranspiration (IPCC 2014, Part B). This is the case even though most IPCC models predict an increase in rainfall across most of South America. Drought leads to more forest fires, which are a great threat to the Brazilian Amazon and reinforce the temperature increase by releasing more carbon dioxide into the atmosphere.

In the past, and given low numbers of indigenous peoples, deforestation and scarcity of resources have not yet played an important role. However, given deforestation trends in three of the four case study indigenous territories and high population growth, in addition to some indigenous communities asking for more land, there is the question of how sustainable indigenous land rights will be in the future. In chapter three, I will analyze the impact of land demarcation on forest conservation.

\subsection{CONCLUSIONS}

In chapter two, I found that providing indigenous peoples with the rights to their lands, not only improves their cultural autonomy but also supports their survival by creating livelihood opportunities. Even though a certain level of poverty still exists in remote areas of indigenous territories, living conditions have improved dramatically over the past two decades. This means that indigenous territories at the time of my field visit have access to modern amenities, such as schools, health centers, electricity, and improved sources of water.

The theoretical model of von Thünen helped me explain how proximity to an urban center can influence why some of the four indigenous communities are better off in terms of their livelihood, income, literacy levels, and housing quality. As in the von Thünen theory, I found that an urban center, a road and to a lesser extent a river can make a difference in terms of income and education levels. It is also likely that demarcation alters the von Thünen model. Demarcation tends to make indigenous communities sedentary and create nuclei market centers in the outer concentric circle of the model, the forested area. I found one outlier indigenous 
community that had the highest income, despite a remote location, which can be best explained through migration and remittances.

In chapter two, I used a mix of qualitative and quantitative research methods. Because of a lack of quantitative data about indigenous territories for the decades before 2010, I triangulated my findings with census data and the literature to achieve more robust evidence.

Given the vast extent of the Brazilian Amazon and the large spread of the demarcated indigenous territories under the Indigenous Lands Project, I focused my field visit on the state of Amazonas. Following George and Bennett (2005), I chose a most-different systems design to be able to draw conclusions from a small sample of only four case studies.

In summary, this chapter fills an important research gap in the literature in that it explores how the population living in indigenous territories is able to survive and how demarcation and monitoring support led to improvements in indigenous peoples' livelihoods. It refutes the counter-hypothesis that making indigenous peoples sedentary by providing them with a land title is a threat to the indigenous way of life and well-being. This section answered the first research question based on a field visit to four indigenous territories in the Brazilian Amazon state of Amazonas and triangulated findings with statistical data from the IBGE, the NGO ISA, and the literature.

Based on the above explorations, I conclude that indigenous peoples that decided to live in indigenous territories are not worse off due to demarcation and land titling, although major threats to their survival and well-being exist. I explored this research questions along the four dimensions of (1) demarcation and enforcement; (2) livelihoods and income; (3) access to basic services; and (4) presence of indigenous peoples in indigenous territories.

First, according to focus group discussions, indigenous peoples seem content with the rights to their lands, which has become the new normal. However, resource conflicts pose a major and continuous threats to the subsistence of indigenous communities. However, as a mediating factor, the Brazilian state provides welfare payments to poor families in Brazil, among them many indigenous families. Thus, the elderly and poor families, preferably women, receive small monthly stipends that in the past have contributed to alleviate poverty, although it also influences consumption patterns with negative effects on health (i.e., soft drinks, meat, etc.) and involves high transportation costs, to access the funds. 
Second, focus group discussions and data from the IBGE 2010 census reveals that indigenous peoples make a living out of the indigenous lands by hunting, gathering, and shifting cultivation. In addition, they receive income from work in nearby urban centers, by collecting road tolls, and by welfare payments to mothers and elders.

Third, according to my observations and IBGE 2010 census data, indigenous communities living in indigenous territories have access to basic services, such as schools, community health units, improved sources of water, and access to electricity. However, access to basic services lacks behind the urban centers and Brazil's south, especially with respect to sanitation and garbage disposal. Therefore, maternal mortality and infant mortality is still relatively high in the rural areas of Brazil's Northern region.

Fourth, my field visit to four indigenous communities confirmed that more indigenous peoples were actually living in indigenous territories now than two decades ago. I saw wooden and brick houses, schools, health units being used and I discussed life and living conditions with the inhabitants of the indigenous territories. According to population data, there has been aboveaverage population growth among indigenous peoples living in indigenous territories. This growth was more pronounced in the North than in the South, in rural areas rather than urban, and in indigenous territories rather than outside indigenous areas.

This leads me to conclude that more indigenous peoples in indigenous territories actually live in these territories than two decades ago, that many of them prefer a life in rural rather than urban areas, and that living conditions and the survival of the indigenous population have dramatically improved since the start of the Indigenous Lands Project even though they may not yet be at the level of indigenous peoples in the South, or non-indigenous peoples in the South and in urban areas. I therefore would like to reiterate my conclusion that demarcation and the provision of land titles for indigenous peoples did help communities to survive and prosper. 


\section{THE IMPACT OF DEMARCATION ON FOREST PRESERVATION}

\subsection{INTRODUCTION}

In the preceding chapters I went on a quest to find some of the factors that explain how annual deforestation in the Brazilian Amazon forest declined so fast between 2004 and 2012. Specifically, I set out to focus on environmental policies. Chapter two explored the effects on the ground of one environmental policy. The policy supported the demarcation and thus preservation of indigenous lands that represent about 20 percent of the land area of the Brazilian Amazon forest. However, as eye-opening as an expedition to four of the indigenous territories was, it was difficult to see the forest for all the trees. I needed to do more to assert the claim that the indigenous communities were preserving the forest.

To gain a sense of how much forest has been preserved through demarcating indigenous territories, I need to use satellite data and rigorous impact evaluation methodology. By using these quantitative methods, I want to answer my second research question: "What has been the effect of demarcating indigenous territories on forest preservation?" I use an unexplored dataset from Brazil's Indigenous Organization FUNAI with demarcation dates, developed under the Indigenous Lands Project (Projeto Integrado de Proteção às Populações e Terras Indígenas da Amazônia Legal, PPTAL, the same project described in chapter two). I add to the literature by comparing forest cover in communities that have been demarcated with those that have not, something that has not been done before.

The research in this chapter is based on a dataset shared by FUNAI and an ex post evaluation conducted for the KfW Development Bank and its evaluation unit (Financial Cooperation Evaluation FZE, German acronym). While working on my Ph.D. and working in the German KfW Development Bank, I cooperated with Ariel BenYishay, Daniel Runfola, and Rachel Trichler from AidData at the College of William and Mary in Williamsburg, Virginia, United States. I presented this research in the bi-annual GPAC sessions at UNU-MERIT and at the 18th Annual BIOECON Conference on "Instruments and Incentive Mechanisms for Biodiversity Conservation and Ecosystem Service Provision" in September 2016 at Kings College, Cambridge, U.K., and incorporated comments in the published paper. The resultant article was published in the Journal of Environmental Economics and Management in July 2017. Below is 
a reprint of the article as published (except for some footnotes that I added in this version). I use the pronoun "we" in this section given that I prepared this section together with collaborators as described in detail in Table 1 of this book.

\subsection{INDIGENOUS LAND RIGHTS AND DEFORESTATION: EVIDENCE FROM THE BRAZILIAN AMAZON ${ }^{60}$}

\subsubsection{Abstract}

Concerns over the expropriation of and encroachment on indigenous communities' lands have led to greater formalization of these communities' rights in several developing countries. We study whether formalization of indigenous communities' land rights affects the rate of deforestation in both the short and medium terms. Beginning in 1995, the government of Brazil formalized the rights of several hundred indigenous communities whose lands cover more than 40 million hectares in the Amazon region and provided support for these rights' enforcement. We study the program's impacts using a long time series of satellite-based forest cover data. Using both plausibly exogenous variation in the timing of formalization and matched samples of treated and comparison communities, we find no effect of these protections on satellitebased greenness measures. This is true even for communities that received support for surveillance and enforcement of these rights. Notably, we observe low counterfactual rates of deforestation on communities' lands between 1982 and 2010, suggesting that indigenous land rights programs should not uniformly be justified based on their forest protection, at least in the medium term.

\subsubsection{Introduction}

Concerns over the expropriation of and encroachment on indigenous communities' lands have led to greater formalization of these communities' rights in many developing countries. When

\footnotetext{
${ }^{60}$ This work was supported by the evaluation department of KfW Development Bank. The views and results presented do not necessarily reflect those of KfW or its directors. Seth Goodman played a key role in processing the satellite and covariate data; Artur Nobre Mendes, Juliana Sellani, Dan Pasca, and Sebastian Weber made it possible to obtain the project-level data; Alec Shobe and Aishwarya Venkat provided excellent research assistance. We thank Ken Chomitz, Priya Mukherjee, Brad Parks, Cathal O’Donoghue, Kate Sims, and seminar participants at the World Bank's Independent Evaluation Group, USAID, the BIOECON conference, and William \& Mary for helpful comments.
} 
enforced, the improvement in these rights can help indigenous communities prevent incursions into their territories. Of particular importance are rights for indigenous communities ${ }^{61}$ inhabiting tropical forests, where ambiguity over and weak enforcement of land rights often lead to unsustainable resource extraction and conversion of forest to agricultural use. In Brazil, these concerns led the government to enshrine its commitment to formalizing indigenous peoples' territorial rights in its 1988 Constitution. Since then, indigenous lands have been formalized on more than one-fifth of the Brazilian Amazon, often in locations near the expanding deforestation frontier.

The policy-relevant question is whether improving these communities' rights can protect their lands from increasing deforestation. However, prior studies of the relationship between indigenous communities' land rights and deforestation have not examined changes in land rights, limiting the conclusions policymakers can draw when considering whether strengthening land rights for these communities will result in lower forest loss.

Why might improvements in land rights for indigenous communities affect the pace and extent of deforestation? Bohn and Deacon (2000) provide a theoretical framework through which weak land rights affect the rate of forest harvesting (as well as use of other natural resources). In their model, less secure rights over lands with standing forests lead unambiguously to faster forest harvesting, as future risks diminish the discounted future value of the forests. Thus, communities may slow their own harvesting in response to extended prospects of retaining their land. Perhaps even more directly, if encroachment on these communities' lands is motivated by resource extraction, more secure rights reduce the likelihood of expropriation and thus deforestation by encroachers. Araújo et al. (2009) suggest that tenure insecurity may itself motivate encroachment and deforestation by squatters as a strategy to eventually gain formal title to land. Both mechanisms depend on the expropriation risk level: for sufficiently low risks, land rights themselves do not affect forest harvesting rates. ${ }^{62}$

\footnotetext{
${ }^{61}$ For the remainder of this paper, we refer to indigenous communities each time we use the term 'communities.'

${ }^{62}$ Other mechanisms through which land rights interventions often affect welfare (laid out by Besley 1995) are less plausible in this context: communal ownership of land did not allow pledging this land as collateral for credit, and the non-transferability of these rights did not affect investments related to expectations of future sale or leasing.
} 
Consistent with both mechanisms, evidence from the broader literature largely finds land rights improvements to be associated with slower deforestation and better agricultural results. Robinson et al. (2014) conduct a meta-analysis of 118 sites covered by 36 papers in this literature (largely in non-indigenous contexts) that plausibly control for potential confounds, and find generally positive effects. Most salient for our case, Araújo et al. (2009) find substantial deforestation reductions in Brazil associated with improved tenure security (again, among non-indigenous communities). Similarly, Nelson et al. (2001) find slower deforestation in lands with greater protections in a remote province of Panama. More broadly, Lawry et al. (2014) provide a meta-analysis of land rights improvements on agricultural (rather than forested) lands and show gains in productivity, consistent with a more general theory of investment responses on better-secured lands. In the Brazilian Amazon itself, Alston et al. (1996) document similar agricultural responses to private titling.

These promising results from improvements in the security of rights over non-indigenous lands coalesce with findings from the literature studying indigenous communities. As noted above, this literature has to date assessed indigenous control as a static set of rights (Nepstad et al. 2006, Nelson and Chomitz 2011, Nolte et al. 2013, Pfaff et al. 2014, Vergara-Aseno and Potvin 2014). Using both global and within-country comparisons and controlling for features that differentiate other kinds of lands from indigenous ones, these studies find that indigenous lands generally exhibit slower deforestation rates than those with other governance forms, be they privately owned, publicly owned but eligible for sustainable use, or publicly owned protected areas. A notable exception is Buntaine et al. (2015), which finds no impacts on deforestation of formalization of land rights in one region of Ecuador but whose external validity is limited. ${ }^{63}$

Formalizing the land rights of indigenous communities may therefore serve as a viable policy to conserve tropical forests. However, to date, no study has reliably assessed this claim on a large scale. Moreover, if baseline risks of deforestation among these communities are not high, improvements in land rights may lead to only small or even no reductions in deforestation.

These literatures highlight the dual empirical challenges in assessing impacts of changes in indigenous land rights: one needs (1) carefully documented time variation in the extent of rights, and (2) sufficient spatial variation for statistical analysis robust to spatial clustering and

\footnotetext{
${ }^{63}$ Buntaine et al. (2015) also do not account for spatial auto-correlation in error terms or observables, possibly because such auto-correlation potentially saps the statistical power available in small-scale studies.
} 
potential spillovers (Robalino, Pfaff, and Villalobos 2015, and Robalino et al. 2015 document important interactions and spillovers in forest conservation). Micro-studies of one region document the timing of rights improvements but lack statistical power once spatial effects are adequately addressed. Global studies provide sufficient spatial variation but do not document changes in rights across an array of national legal systems.

We overcome these limitations by studying the Brazil Indigenous Lands Project (PPTAL), which formalized the land rights of 106 indigenous communities covering more than 38 million hectares of largely forested area between 1995 and 2008. Brazil's 1988 Constitution guaranteed "original rights to the lands [indigenous peoples] traditionally occupy" and assigned responsibility to the state to demarcate these lands and ensure respect for these communities' property rights. ${ }^{64}$ All indigenous communities thus had de jure rights to their lands, but the land formalization process (including demarcation and registration) formally secured these land rights. This paper measures the averted losses in forest cover due to the legal formalization of these de jure rights.

Importantly, PPTAL identified the set of communities to be assisted ex ante and prioritized rights formalization based on a defined set of community characteristics. We carefully document the dates at which different phases of formalization were completed for each community, as well as each community's geographic extent. Using the plausibly exogenous variation in the timing of formalization, we adopt a panel framework that controls for community-specific fixed effects and trends, as well as time-varying covariates. This allows us to compare post-formalization forest cover to counterfactual outcomes obtained from communities' own preceding levels and trends, as well as the contemporaneous outcomes of not-yet-formalized communities. Furthermore, by exploring within-community (i.e., grid celllevel) variation in encroachment risks based on distance to a community's boundaries,

\footnotetext{
${ }^{64}$ According to Brazil's 1988 Constitution, Chapter 8, Article 231: "Indians shall have their social organization, customs, languages, creeds, and traditions recognized, as well as their original rights to the lands they traditionally occupy, it being incumbent upon the Union to demarcate them, protect and ensure respect for all of their property." Thus, the state is responsible to physically demarcate the limits of the indigenous land. Chapter 2, Article 20 (XX) of the Constitution declares Indigenous lands as the Union's property. This has meant in practice that above-ground property belongs to the indigenous community, while water resources and minerals belong to the state and can be extracted or dammed after consultation with the indigenous community. Retrieved from: http://pdba.georgetown.edu/Constitutions/Brazil/english96.html\#mozTocId506170.
} 
preceding deforestation, and other measures of forest pressure, we assess whether these risks were large enough to activate the own-harvesting and intrusion mechanisms described above.

We find no effects of formalization on forest cover in our panel data framework. We further decompose the effects by whether a community also received support for surveillance and enforcement, and detect no differential impacts from the combined treatment of this support and demarcation. Employing higher resolution imagery available for the latter part of our sample period, we again find no significant impacts on greenness, even in forested areas closer to the boundaries of the communities and among communities with the highest risk factors. Taken together, we find consistent estimates of only negligible treatment effects of PPTAL, estimates that are not limited by insufficient precision.

We also adopt a less restrictive approach that does not rely on each community's specific year of demarcation for identification. Project records indicate that the timing of the primary treatment was sharp, but this specification nonetheless allows for potential fuzziness in the timing associated with other (unobserved) benefits that occurred either before or after the actual demarcation, as well as any project-wide benefits that began accruing simultaneously to all participating communities. We therefore use propensity score matching to construct comparisons of formalized communities and a subset of the communities that PPTAL preidentified but did not prioritize for formalization, finding no differential changes among the formalized communities.

Altogether, we find little evidence that formalization of land rights reduced deforestation among affected indigenous communities. One potential implication is that the posited causal mechanisms did not materialize. However, we also observe relatively low counterfactual rates of deforestation on communities' lands between 1982 and 2014. Many of the indigenous communities in Brazil's Amazon are remote, and thus their forest cover is not yet threatened by deforestation. So, while indigenous communities may indeed experience lower deforestation rates on their lands, these results suggest that their forests are also not necessarily threatened by insecure title. The relevant policy implication is that financing indigenous land rights programs may not show results in the short- to medium-term but may be an investment for a future in which indigenous territories are threatened by deforestation.

This paper is organized as follows: in section 2, we detail the study context, while section 3 describes the data on community lands, satellite-based greenness, and covariates. In section 4, 
we describe the panel data model and present its results using grid cell-level units. Section 5 includes findings from the community-level models. We detail a series of robustness checks in section 6 and offer discussion and conclusions in section 7.

\subsubsection{Study Context}

In the early 1900s, the Brazilian government began to offer protection to the indigenous population, treating Indians as wards of the state and guaranteeing protection of traditional lands (Ortiga 2004). As most indigenous peoples resided in the nine states of the Legal Amazon, ${ }^{65}$ by the 1980 s indigenous lands accounted for 89 million hectares (17.5 percent) of the land area in the region, most of which maintained native forest cover despite its use for subsistence (World Bank 2007).

Yet indigenous lands lacked formal legal recognition. Indigenous populations suffered from stigma and violence, and a series of federal ministries established to oversee the state's protection of indigenous rights struggled with corruption, lack of resources, and illegal activities by miners and loggers (Ortiga 2004). International pressure to stem the destruction of Brazil's rainforests also came to a head in the 1980s, due to the size of the Amazon and its global importance for watershed, biodiversity, and climate maintenance. Indigenous populations' stewardship of tropical forests provided a model of sustainable development, exemplifying the Brazilian view that its rainforests are both a natural resource to be protected and a source of wealth to be utilized (World Bank 2007).

In 1988, Brazil adopted a new constitution that aimed to legally recognize indigenous lands. Article 231 stipulates that Indians shall have their original rights to the lands they traditionally occupy recognized through demarcation and registration of land title, "it being incumbent upon the Union to demarcate them, protect and ensure respect for all of their property." One year later, the ILO adopted Convention No. 169 Concerning Indigenous and Tribal Peoples in Independent Countries, which recognizes "the rights of ownership and possession of the peoples concerned over the lands which they traditionally occupy" (ILO 1989). Nearly 20 years later, the United Nations adopted the UN Declaration on the Rights of Indigenous Peoples,

\footnotetext{
65 The Legal Amazon includes the Brazilian states of Acre, Amapá, Amazonas, Pará, Rondônia, Roraima, and parts of Maranhão, Mato Grosso, and Tocantins.
} 
stipulating that "indigenous peoples have the rights to the lands, territories and resources which they have traditionally owned, occupied or otherwise used or acquired" (United Nations 2007).

The indigenous land rights conferred in Brazil's 1988 Constitution differ from individual land rights in the following three respects:

(1) Indigenous lands are inalienable and unmortgageable (Ortiga 2004, Katz 2010) and perceived as a cultural heritage site because of the special relationship of indigenous peoples to their land (Wiessner 2011).

(2) Indigenous land titles are collective rather than individually held (Katz 2010).

(3) Indigenous land titles provide indigenous peoples with the right to use everything above ground for their livelihood, such as fishing, hunting, gathering, and shifting cultivations.

In addition to granting indigenous land rights, Article 67 of the Temporary Provisions of the 1988 Constitution further required the demarcation of all 532 recognized indigenous areas by 1993. The de jure rights afforded by the constitution thus required implementation via a formalization process that included demarcation, approval, and registration to become de facto rights. Formally, the rights provided in the constitution could not be applied until a community had completed this process. However, five years later, only 50 percent of indigenous lands had been demarcated. The missed deadline was largely due to inadequate resources for the National Indian Foundation (FUNAI), the ministry tasked with protecting indigenous areas (World Bank 2007).

PPTAL was conceived to respond to the need for greater resources and attention to carry out the formalization process. It was one part of a larger multi-donor effort known as the Pilot Programme for the Protection of Brazilian Rain Forests (PPG7). PPTAL was implemented by FUNAI from 1995 to 2008, with funding from German KfW and the Rain Forest Trust Fund managed by the World Bank. The project's main objective was to "improve the conservation of natural resources in indigenous lands and increase the well-being of indigenous people." The project consisted of three main components: i) regularization of indigenous lands; ii) surveillance and protection of indigenous lands; and iii) capacity building and assessments (World Bank 2007).

This paper focuses on the project's first and second goals to regularize and protect indigenous lands. The process of regularization, or registering lands in municipal, state, and federal 
registries, had several stages. An anthropological study was required to initially identify boundaries, and a series of government approvals were then required to finalize the boundaries: first from FUNAI (the delimitation stage); second from the Minister of Justice (the demarcation stage); and third from the president of Brazil (the approval stage). Finally, entrance into municipal, state, and federal registries was required (the regularization stage). Disputes to the initial boundaries and any subsequent changes were handled during the delimitation stage, such that the boundaries were finalized, physically marked, and officially sanctioned by a government ministry once a community completed the demarcation stage. As documented in an ex post evaluation completed by KfW, the project exceeded its demarcation goals: by PPTAL's completion, 106 indigenous lands had been demarcated, 81 of which were officially registered. An additional 73 indigenous lands were in the identification and delimitation stages. The project records included 181 indigenous lands considered by the project in some capacity, but we could only geographically locate 151 of these. ${ }^{66}$ The evaluation approach further restricted the pool of communities for analysis, as discussed below. Map 7 shows the location of communities in our sample.

\section{Map 7. PPTAL Communities}

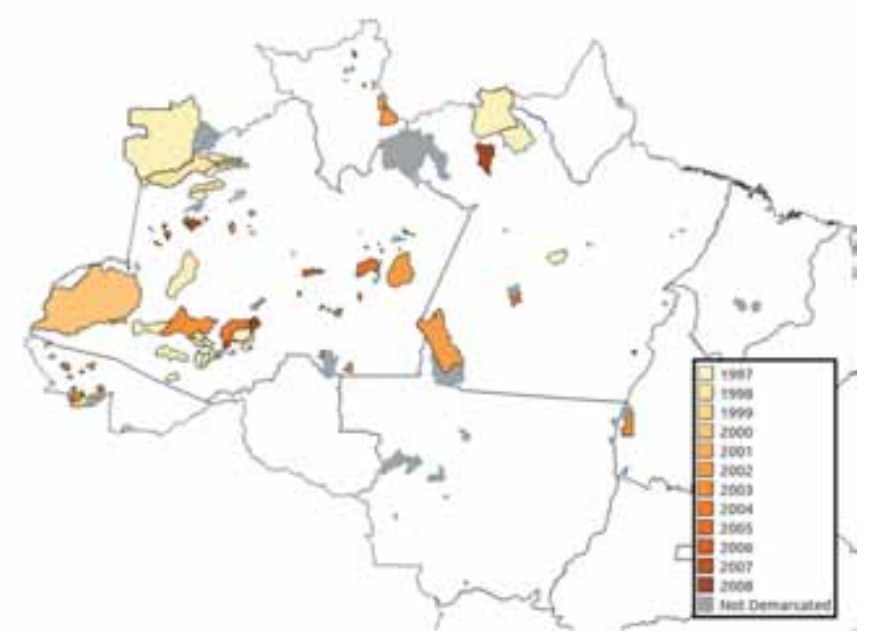

Source: AidData and FUNAI

\footnotetext{
${ }^{66}$ Little is known by the authors about these 30 missing indigenous lands. We are not aware of any systematic differences between missing and located lands, though factors that made the demarcation process more difficult (e.g., land disputes) may indicate a greater need for demarcation, thus increasing the value of the intervention.
} 
The second component of PPTAL focused on protection of indigenous lands, supporting the community-led creation and implementation of surveillance plans in 65 lands. The surveillance plans varied in specifics, but generally supported maintenance of boundaries, GPS training, surveillance routines, transportation acquisition, and the establishment of control posts. As discussed below, we further consider this enforcement support stage as a separate treatment along with demarcation.

We use variation in the timing of the demarcation and enforcement support stages for causal identification among the set of communities studied by PPTAL for potential formalization. Project documents indicate that communities were prioritized for demarcation based on a preliminary assessment of the threats to the natural environment and physical and cultural threats to the indigenous populations. Each community initially studied under the PPTAL project was rated shortly after project inception in 1995, with early support provided to communities seen to be under greatest threat. However, this prioritization does not appear to correlate closely with satellite data on preceding trends in forest conditions. We observe no meaningful difference in pre-trends in our main outcome of interest (deforestation) between 1982 and 1995 across communities' demarcation years. Figure 16 plots these pre-trends and the year of demarcation with a best fit line, as well as 95 percent confidence intervals and a benchmark line with zero slope. The figure documents extensive variation in the pre-trends, and the pre-trends are only slightly higher for later-demarcated communities, with this difference not statistically distinguishable from zero. The slope of the relationship indicates that these differences amount to forest loss per year of at most 0.001 NDVI (greenness) points in the earliest demarcated communities relative to the latest, suggesting that our estimates could at most be biased downward by $0.01 \mathrm{SD}$. 
Figure 16. Demarcation year and NDVI pre-trend, at community level

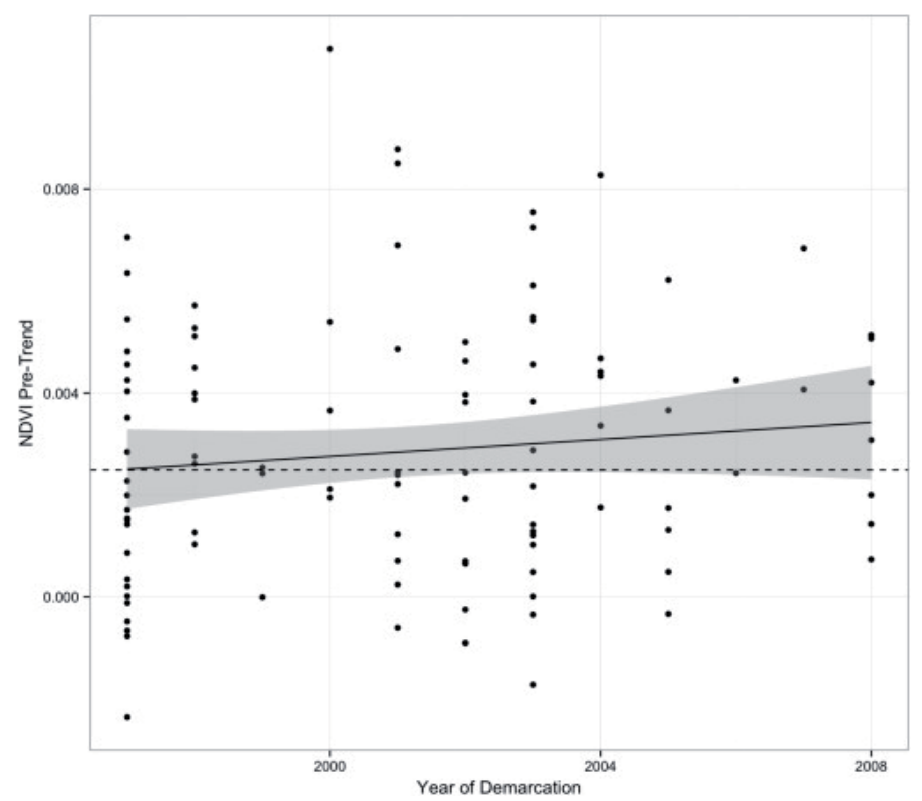

Notes: The solid line indicates a linear fit of the relationship, with shading representing 95 percent confidence intervals. The dashed line represents a zero slope benchmark.

\subsubsection{Data}

\subsubsection{Sample}

Our sample consists of 151 indigenous communities existing in 1995 and studied by PPTAL for potential formalization for which we have geographical information. This sample construction ensures that communities whose lands were not formalized by PPTAL and that may have subsequently been encroached on and disappeared are nonetheless included in our sample (as one might expect from a sample constructed retrospectively from communities still in existence ex post). ${ }^{67}$

When conducting grid cell-level analysis (section 4), we limit the sample to cells that had sufficient land cover at baseline (1995) to indicate likely standing forests (a threshold of 0.6 NDVI, discussed in further detail below). We maintain outcomes at their existing resolution

${ }^{67} \mathrm{We}$ also confirm that our results are robust to narrower sample constructions that trim communities based on (a) whether they are ever demarcated and, separately, (b) propensity scores predicting "early" treatment (pre2001) outside of the common support. Results are available upon request. 
(most frequently the $4 \mathrm{~km} \times 4 \mathrm{~km}$ pixel size) and aggregate covariates to the mean value within the pixel.

When assessing changes in community-level models (section 5), we aggregate all spatially explicit data to the mean value within the boundaries of the community.

\subsubsection{Outcome Data}

We use remotely sensed satellite imagery for each community covering 1982-2010 from the NASA Land Long-Term Data Record (LTDR). This data was processed to calculate a commonly used land cover metric that captures on-the-ground biomass, the Normalized Difference Vegetation Index (NDVI). The LTDR NDVI ranges from 0 to 1, where 0 indicates rocky or barren terrain, and 1 indicates densely forested terrain. This data was retrieved from Version 4 of the LTDR, which uses processed satellite information from the AVHRR and MODIS satellites (including corrections for detrimental factors such as atmospheric artifacts, clouds, and other sources of noise) at the $4 \mathrm{~km} \mathrm{x} 4 \mathrm{~km}$ pixel size. It was received at a global scale for each day during the time series ${ }^{68}$ with approximately 26 million pixels in each image. Our full-scale sample included 29 annual observations on each of 14,554 cells; once we trim the sample as discussed below in section 4 , there are 8,483 cells in our primary sample.

Figure 17 contrasts our dataset from the LTDR with a heavily studied instance of deforestation in the Manicoré Region, Brazil. The top image is drawn from a report by the World Resource Institute on satellite-based forest clearing detection and is a circa-2004 visible-band image used to contrast different datasets (Wheeler et al. 2014). The bottom image is the raw continuous measurement data from the LTDR NDVI dataset during the same year. While there are important tradeoffs between the LTDR and other satellite datasets, the LTDR data record provides not only sufficient spatial resolution to capture key deforestation trends (as illustrated by these images), but also a continuous time record extending back over nearly 30 years.

\footnotetext{
68 This analysis is conducted using the SciClone High Performance Cluster computing environment at William and Mary, reducing the 283 billion pixels of data to yearly aggregate summaries for each community studied.
} 


\section{Figure 17. Comparison imagery from Manicoré Region, Brazil}
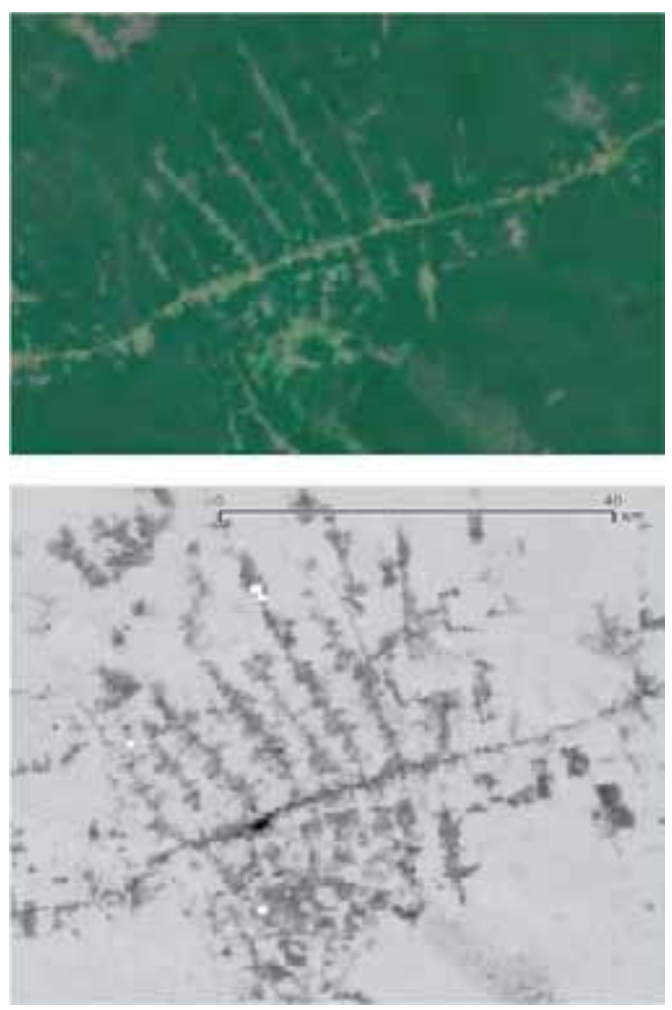

Source: Comparison Imagery from Manicoré Region, Brazil. Top image is drawn from a report by the World Resource Institute on satellite-based forest clearing detection and is a circa-2004 visible-band image used to contrast different datasets (Wheeler et al. 2014). The bottom image is the raw continuous measurement data from the LTDR NDVI dataset during the same year.

A common critique of NDVI is that it is heavily saturated and noisy over areas with dense biomass such as the Amazon, preventing its use for some applications (i.e., forest densification). Here, NDVI provides a strong proxy for deforestation, as (a) the difference in NDVI values between forested and deforested lands is very large, and (b) the daily time-step of the available data over the entire time series allows us to allay data quality concerns.

We aggregate the daily NDVI values into annual measures, the finest timing for most of our covariates. To do so, we calculate the maximum and median NDVI values in each year. The maximum value approximates the highest point of observable plant productivity (i.e., the "greenest" period of the year), providing the best measurement of total vegetation in any given year. However, maximum values are more sensitive to noise in the data. The median values are 
more robust but can fail to represent the true total amount of vegetation due to the differential "averaging out" of vegetative maximums through winter periods. We thus use the maximum NDVI as our main outcome measure and conduct robustness checks employing the median NDVI instead.

As a robustness check discussed in section 6, we also use the Global Inventory Monitoring and Modeling System (GIMMS) NDVI measure derived from only the MODIS-era (Feb. 2000 onwards) imagery and available at the $250 \mathrm{~m}$ spatial resolution.

\subsubsection{Treatment Data}

We obtained data from PPTAL's implementing agency FUNAI on the month and year in which each of the 151 communities were initially studied, as well as the dates when communities completed the demarcation and approval stages (for the subset of 106 communities that did so). In addition, we obtained data on the dates when provision of support for community enforcement began in the 45 sample communities where this support was provided.

Our first indicator of treatment is a community's completion of the demarcation stage. Completion of the demarcation stage was a major milestone, as it was when the community received the first layer of official approval from the Ministry of Justice. The community lands' physical boundaries remained unchanged after this point, though additional formal declarations could take place after this stage. Most communities whose lands reached the demarcation stage were subsequently regularized, so this first treatment status can be considered as reaching at least the demarcation stage. We use administrative data from PPTAL identifying each community that received support for land rights enforcement as a second indicator of treatment.

\subsubsection{Covariate Data}

Covariate data was collected from a variety of sources. A long-term climate data record was retrieved from the University of Delaware ${ }^{69}$ providing precipitation and temperature data over the full panel series at a 0.5 -degree resolution on a monthly time-step; this was processed to produce yearly mean, minimum, and maximum values. Population data at 5-year intervals was retrieved from the Gridded Population of the World (GPW) data record, produced by CIESIN at Columbia University. ${ }^{70}$ Slope and elevation data was derived from the NASA Shuttle Radar

\footnotetext{
${ }^{69}$ http://climate.geog.udel.edu/ $\square$ climate/.

${ }^{70} \mathrm{http}: / /$ sedac.ciesin.columbia.edu/data/collection/gpw-v3.
} 
Topography Mission (SRTM). ${ }^{71}$ Distance to rivers was calculated based on the USGS Hydrosheds database. ${ }^{72}$ Distance to roads was calculated based on the Global Roads Open Access Database (gRoads), which represents roads circa 2010. ${ }^{73}$

Our interest is in results that are representative of impacts at the community rather than cell level, but our cell-level sample over-weights geographically larger communities. We account for this by constructing weights based on the inverse of each community's geographic area and employing these in our estimation.

Table 13. Summary statistics for LTDR grid cell-level panel dataset, weighted by community size.

\begin{tabular}{|c|c|c|c|c|c|}
\hline Variable & Mean & St. Dev. & Min & Max & $\begin{array}{c}\text { Correlation } \\
\text { with } \\
\text { demarcation } \\
\text { yeara) }\end{array}$ \\
\hline NDVI & 0.756 & 0.093 & 0.00 & 0.996 & -0.144 \\
\hline Slope (deg.) & 0.536 & 0.39 & 0.031 & 12.88 & 0.095 \\
\hline Distance to road (m) & $61,251.67$ & $92,640.74$ & 660.12 & $489,285.40$ & 0.002 \\
\hline Distance to river (m) & $1,570.88$ & 832.187 & 238.354 & $5,571.00$ & 0.038 \\
\hline Elevation (m) & 90.7 & 85.304 & 1.335 & 720.1 & -0.087 \\
\hline Area (hectares) & $88,258.86$ & $550,572.40$ & 142.298 & $8,544,482.00$ & -0.116 \\
\hline Population density & 2.288 & 19.569 & 0.00 & 1085 & -0.013 \\
\hline Mean temperature & 24.352 & 0.697 & 21.38 & 29.277 & 0.068 \\
\hline Mean precipitation & 171.066 & 26.731 & 64.04 & 359.596 & -0.096 \\
\hline Max temperature & 25.357 & 0.829 & 22.307 & 31.165 & 0.077 \\
\hline Max precipitation & 303.34 & 45.43 & 142.9 & 689.705 & -0.019 \\
\hline Min precipitation & 60.27 & 29.991 & 2.363 & 230.447 & 0.008 \\
\hline Min temperature & 23.391 & 0.885 & 16.728 & 27.115 & 0.114 \\
\hline NDVI pre-trend & 0.0026 & 0.002 & -0.004 & 0.016 & 0.098 \\
\hline Predicted NDVI pre-trend & 0.0033 & 0.001 & -0.0003 & 0.005 & -0.048 \\
\hline
\end{tabular}

a) For demarcated sub-sample only. Weighted by inverse of community size to reflect community-level correlation.

We construct a cell-year-level panel dataset for 1982-2010. Table 13 presents summary statistics for this dataset for all 151 communities, weighted by the inverse of community size. It also documents the correlation between each variable and the demarcation year (for the formalized sample), complementing the results documented in Fig. 2 for pre-trends in our outcome measures. In general, we find correlations between NDVI levels and pre-trends that are very small (or 0.1 ). Correlations with several other variables are in the $0.2-0.4$ range, and

\footnotetext{
${ }^{71}$ http://www2.jpl.nasa.gov/srtm/.

72 http://hydrosheds.cr.usgs.gov/index.php.

${ }^{73} \mathrm{http}: / /$ sedac.ciesin.columbia.edu/data/set/groads-global-roads-open-access-v1
} 
these indicate that communities with warmer average temperatures and lower average rainfall (in terms of the annual mean, max, and min of these variables) were more likely to be demarcated later. As we show in subsequent regressions, the effects of demarcation change only slightly when these time-varying conditions are included as controls.

\subsubsection{Grid Cell-Year Panel Model}

Our primary estimation of treatment impacts employs a panel structure drawing from annual data at the grid cell level. We opt for grid cell rather than community-level units to improve precision through greater specificity in both covariates and the timing of treatments. Our climatic and forest cover variables are both available at the cell level, allowing us to reduce statistical variability in our outcome measures that is conditional on climate conditions. To do so, we control for the mean, maximum, and minimum monthly temperatures and rainfall in each year at the cell level. In addition, we also control for time invariant features of each cell by including year fixed effects. We use two-way clustering of standard errors by community and year, as this is the scale at which treatment is assigned (following Cameron et al. 2011). This approach provides additional granularity, while also accounting for spatial autocorrelation among forest cells in the same indigenous community.

Using this dataset, we estimate the following equation: ${ }^{74}$

$N D V I_{i c t}=\alpha+\beta_{1}$ Demarcated $_{c t}+\beta_{2}$ Enforcem $_{\cdot c t}+$ CClimate $_{i c t}+D_{i}+D_{t}+\epsilon_{i c t}$

Where Demarcated $_{c t}$ indicates whether cell $i$ in community $c$ has been demarcated by year $t$, Enforcement $_{c t}$ indicates whether enforcement support has begun, Climate $_{i c t}$ is a vector of the aforementioned temperature and precipitation controls, $D_{i}$ is a vector of communityspecific fixed effects and $D_{t}$ are year fixed effects. We estimate treatment effects via ordinary least-squares, ${ }^{75}$ with two-way clustering of standard errors by community and year. Estimating

\footnotetext{
${ }^{74}$ By "Demarcated" we mean individual indigenous communities that received land demarcation support (GPS mapping and marking boundaries with panels and stones) in a specific year as an important step toward receiving a community land title. By "Enforcement" we mean whether a community received enforcement training, to patrol the indigenous lands regularly and report any border violations or natural resource conflicts. By "Climate" we mean temperature and precipitation that strongly affect biomass and that we included as control variable in our model.

${ }^{75}$ Very few of our observations are at the maximum of our NDVI measures $(0.03 \%$ of cell-year observations with NDVI 40.99$)$ or minimum $(0.2 \%$ of cell-year observations with NDVI $1 / 40)$, so linear models are
} 
effects on the level of NDVI using fixed effects is akin to assessing impacts on changes in NDVI (see Angrist and Pischke 2009).

Table 14 presents the effects on max NDVI. ${ }^{76}$ Column 1 shows estimation of a model with only cell-level fixed effects (and no time controls), with treatment associated with 0.039 reduction in NDVI. These effects obtain even when adding time-varying climate and population controls (Column 2). However, these effects appear to be entirely due to the secular trend in NDVI in our sample: Column 3 adds linear year effect as a control, resulting in a treatment effect reduced by 85 percent and no longer statistically different from zero. Column 4 incorporates year-specific fixed effects and obtains very similar results. Our estimated coefficients on treatment are quite small in these specifications (the estimates are only 0.5 percent of the sample mean of the annual maximum of NDVI) and precisely estimated (with standard error equal to 0.002 , allowing us to detect effects of 0.6 percent of the sample mean of max NDVI).

appropriate.

${ }^{76}$ Robustness checks in Section 6 discuss the qualitatively similar results using the annual median of NDVI as our outcome measure of interest. 


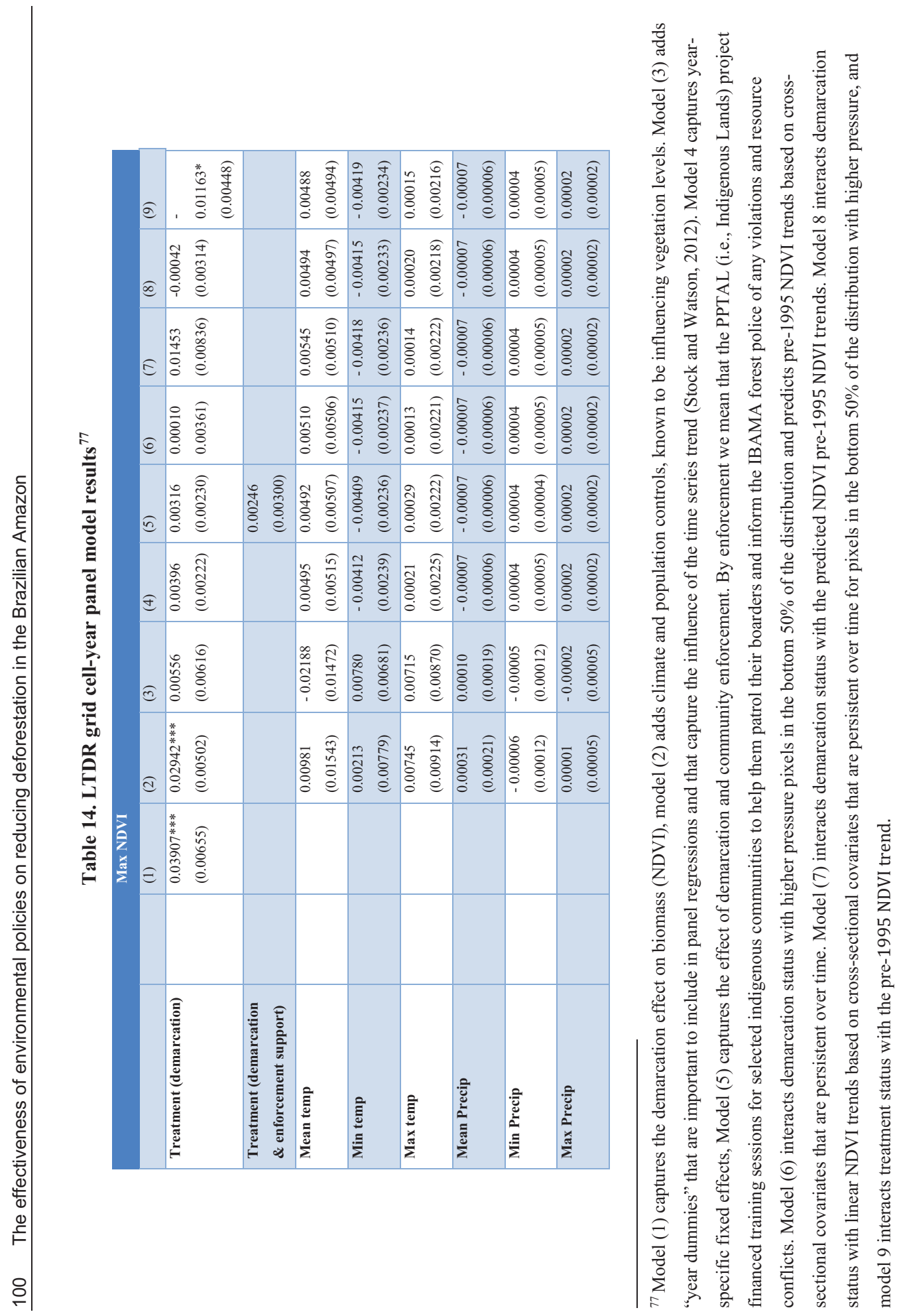




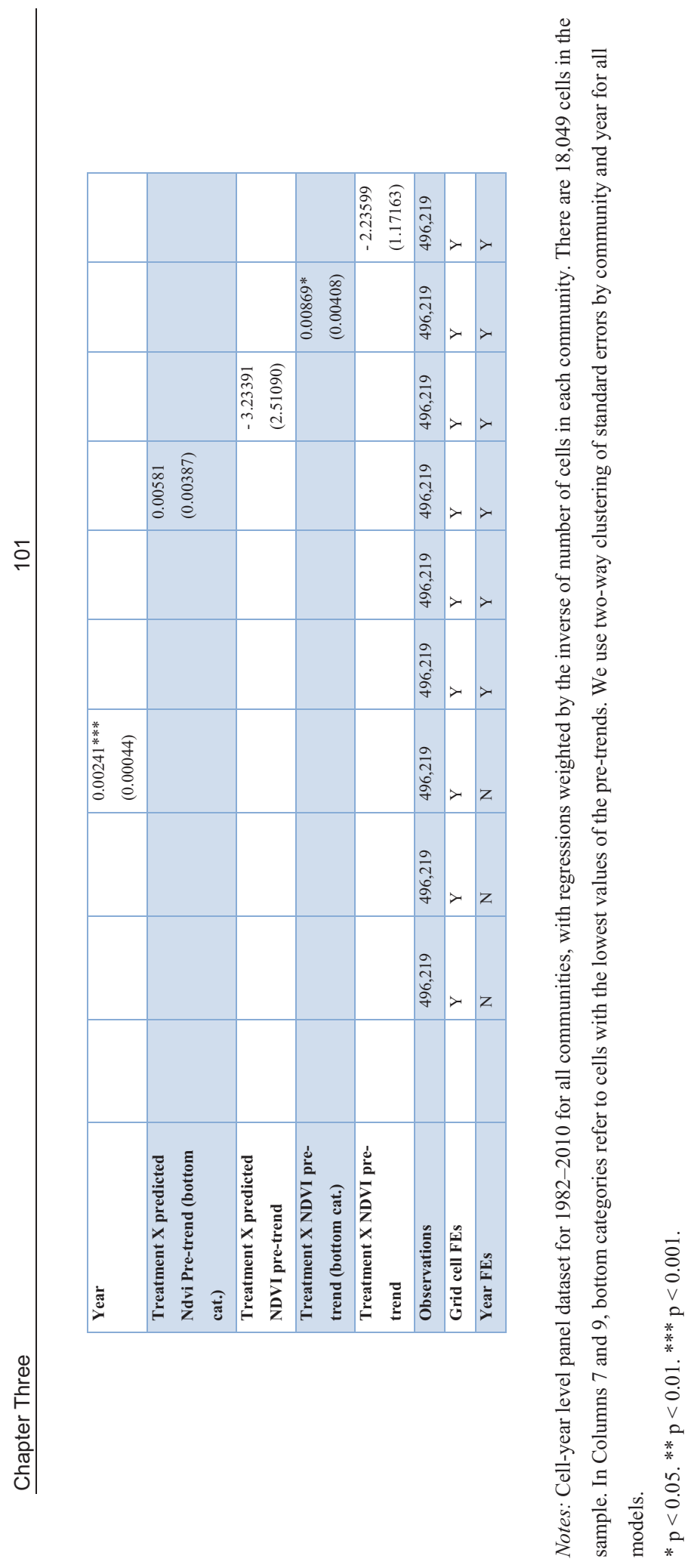


Examining effects of community enforcement (Column 5 of Table 14), we observe no significant effects of enforcement support on forest cover. Notably, this is not due to limited statistical precision; our point estimates are again reasonably small ( 0.3 percent of mean NDVI), as are standard errors (allowing us to detect effects of 0.8 percent of mean NDVI).

We also consider whether results vary by the baseline deforestation pressures on each community's land. Pfaff et al. (2015) document that deforestation rates vary considerably across indigenous lands, partly based on distance to the deforestation frontier. Because many of the lands are in states in the Legal Amazon where agricultural conversion and timber extraction have occurred relatively more slowly, averaging effects across all grid cells could mask improvements in high-pressure areas.

We therefore identify high-pressure cells in several ways. First, we use each cell's pre-1995 NDVI trends as a measure of pre-existing pressure. We also consider higher pressure cells as those where these pre-trends are in the bottom 50 percent of the distribution (i.e., where changes in forest cover were most negative). Because the pre-1995 NDVI changes may be subject to variability or considerable fluctuations, we also predict these trends based on cross-sectional covariates that are persistent over time. We add nighttime lights and several measures of agricultural production prior to 1995 to the set of covariates. ${ }^{78}$ Again, we use both linear terms in the predicted NDVI trends and a dichotomous measure that categorizes these predicted NDVI trends into the bottom 50 percent. We then interact each of these various measures with our timevarying treatment status to assess whether treatment effects are more (or less) pronounced in higher pressure areas.

The results, shown in Columns 6-9 of Table 14, indicate that there is no systematic, statistically distinguishable heterogeneity in the treatment effects across these measures of higher pressure. When using the pre-trends themselves (Columns 8 and 9), we observe that cells with lower pretrends (those where forest loss was faster) experienced slightly differential gains in forest cover. In Column 8, we find that the post-demarcation gain among the half of cells with the worst pretrends was 0.0087 NDVI points, significant at the 5 percent level. This effect is roughly 1.2 percent of the mean and 13 percent of the standard deviation of NDVI, reflecting a relatively small effect detected due to the reasonably low variance in NDVI in our sample. Columns 6-7 show similarly signed effects, but in this case not statistically significant effects. We thus

\footnotetext{
${ }^{78}$ These measures are corn value and yield, rice yield, and sugarcane value and yield.
} 
conclude that there may have been some improvements among the most threatened forest cells, but that these improvements are not large enough to be robustly detected.

Significantly, enforcement of community rights was affected not only by the project itself but also by the broader regulatory environment in Brazil, which experienced important improvements in the latter part of our study period. Beginning in 2004, the Brazilian federal government began integrating several technological features into its monitoring and coordination efforts, including a satellite-based system formally known as the Real-Time System for Detection of Deforestation (DETER). The satellite imagery was used to identify deforestation hot spots and alert federal, state, and local law enforcement. Assunção et al. (2014) show that exogenous variation in this monitoring capability due to cloud cover in specific 15-day intervals significantly affected deforestation, and Hargrave and Kis-Katos (2013) provide corroborating panel data evidence. ${ }^{79}$

We therefore assess whether the effects of formalization were realized once these broader sources of enforcement support were put in place, with results shown in Table 15. We interact a post-2004 indicator with the demarcation treatment status in Columns 1 and 2 and the PPTALsupported enforcement treatment status in Columns 3 and 4. We find no statistically distinguishable changes in NDVI across these enforcement windows when looking at demarcation treatment status: estimates of treatment effects in the post-2004 period are only 0.006 NDVI points in Column 2, roughly 0.8 percent of mean NDVI. The enforcement treatment effect is significant when we include linear year effects (Column 3), but that effect does not differ post-2004 and its significance disappears when we include year-specific fixed effects instead (Column 4). Moreover, because long-term trends may have differed across communities in a way that was correlated with the post-2004 indicator, we further control for community-specific linear time trends in Columns 5 and 6. The coefficients on demarcation and enforcement support are not statistically distinguishable from zero in either of these specifications, despite being very precisely estimated (we can detect effects of 0.4 percent of mean NDVI). These results indicate

\footnotetext{
${ }^{79}$ Moreover, beginning in 2008, Brazil's national environmental regulatory agency (IBAMA) launched a second program (known as PPCDAm II) of intensified field inspections and several complementary initiatives. Arima et al. (2014) and Börner et al. (2014) both study the impacts of these enforcement efforts and document large reductions in deforestation in affected municipalities. However, these effects occur largely outside the window during which demarcation status varied (1997-2008) and so are not clearly estimable in our data.
} 
that it is not likely that treatment effects of demarcation materialized only once adequate enforcement support was in place. ${ }^{80}$

Table 15. LTDR grid cell-year panel model results with post-2004 interaction

\begin{tabular}{|c|c|c|c|c|c|c|}
\hline & \multicolumn{6}{|l|}{ Max NDN1 } \\
\hline & (1) & (2) & (3) & (4) & (5) & (6) \\
\hline Treatment (Denurcation) & $\begin{array}{l}0.0039 s \\
(0.00 \mathrm{~m})\end{array}$ & $\begin{array}{l}0.00215 \\
(0.00190)\end{array}$ & $\begin{array}{l}0.00047 \\
(0.00577)\end{array}$ & $\begin{array}{l}0.00021 \\
\text { (000231) }\end{array}$ & $\begin{array}{l}0.00014 \\
(0.00157)\end{array}$ & $\begin{array}{l}0.00031 \\
(0.00150)\end{array}$ \\
\hline Treatunent (Demurcation) X Font-2004 & $\begin{array}{l}0.00268 \\
\text { (0.01066) }\end{array}$ & $\begin{array}{l}0.00349 \\
(0.00243)\end{array}$ & & & & \\
\hline Treatment (Demarcation + Enf, Suppoet) & & & $\begin{array}{l}0.01180^{-} \\
\text {(0.00338) }\end{array}$ & $\begin{array}{l}0.00001 \\
(0.00212)\end{array}$ & $\begin{array}{l}0.00001 \\
(0.00245)\end{array}$ & $\begin{array}{l}-0.00144 \\
(0.00197)\end{array}$ \\
\hline Treatment (Dem + Ent) X Most 2004 & & & $\begin{array}{c}-0.00793 \\
(0.00700)\end{array}$ & $\begin{array}{l}0.00192 \\
(0.00321)\end{array}$ & & $\begin{array}{l}0.00007 \\
(0.00262)\end{array}$ \\
\hline Meas temp & $\begin{array}{l}-0.02198 \\
(0.01458)\end{array}$ & $\begin{array}{l}0.00473 \\
(0.00506)\end{array}$ & $\begin{array}{l}-0.02167 \\
\text { (0.01458) }\end{array}$ & $\begin{array}{l}0.00495 \\
(0.00506)\end{array}$ & $\begin{array}{l}0.00185 \\
(0.00350)\end{array}$ & $\begin{array}{l}0.00 \text { (B) } \\
(0.00350)\end{array}$ \\
\hline Mon tenp & $\begin{array}{l}\text { o.0078s } \\
(0.00689)\end{array}$ & $\begin{array}{l}-0.00001 \\
\text { [0.00238) }\end{array}$ & $\begin{array}{l}\text { 0.00764 } \\
(0.00678)\end{array}$ & $\begin{array}{l}-0.00407 \\
(0.00235)\end{array}$ & $\begin{array}{l}-0.00455^{*} \\
(0.00177)\end{array}$ & $\begin{array}{l}-0.00455^{\circ} \\
(0.00176)\end{array}$ \\
\hline Max temp & $\begin{array}{l}0.00706 \\
\text { (0.0656) }\end{array}$ & $\begin{array}{l}0.00034 \\
(0.00226)\end{array}$ & $\begin{array}{l}0.00729 \\
(0.008<0)\end{array}$ & $\begin{array}{l}0.00032 \\
(0.00223)\end{array}$ & $\begin{array}{l}0.00238 \\
(0.00142)\end{array}$ & $\begin{array}{l}0.00040 \\
(0.00149)\end{array}$ \\
\hline Mean predp & $\begin{array}{l}\text { o.00010 } \\
(0.00019)\end{array}$ & $\begin{array}{r}-0.00007 \\
(0.00006)\end{array}$ & $\begin{array}{l}0.00011 \\
\text { (0.00019) }\end{array}$ & $\begin{array}{c}-0.00007 \\
(0.00006)\end{array}$ & $\begin{array}{l}-0.00009 \\
(0.00006)\end{array}$ & $\begin{array}{l}-0.00009 \\
(0.00005)\end{array}$ \\
\hline Min precip & $\begin{array}{l}-0.00005 \\
(0.00012)\end{array}$ & $\begin{array}{l}0.00004 \\
(0.00005)\end{array}$ & $\begin{array}{l}-0.00005 \\
(0.00012)\end{array}$ & $\begin{array}{l}0.00004 \\
(0.00004)\end{array}$ & $\begin{array}{l}000007 \\
(000004)\end{array}$ & $\begin{array}{l}0.00007 \\
(0.00005)\end{array}$ \\
\hline Max presip & $\begin{array}{l}-0.00002 \\
(0.00005)\end{array}$ & $\begin{array}{l}0.00002 \\
(000002)\end{array}$ & $\begin{array}{l}-0.00002 \\
(0.00005)\end{array}$ & $\begin{array}{l}0.00002 \\
(0.00002)\end{array}$ & $\begin{array}{l}000002 \\
(000002)\end{array}$ & $\begin{array}{l}0.00002 \\
(0.000012)\end{array}$ \\
\hline Yeat & $\begin{array}{l}0.0024=- \\
(0.00046)\end{array}$ & & $\begin{array}{l}0.0024^{-1-} \\
(0.00045)\end{array}$ & & & \\
\hline Observations & 496,219 & 496,219 & 496,219 & 406219 & $\$ 96219$ & 496279 \\
\hline Grid cell ress & $\mathrm{v}$ & $r$ & $\mathrm{r}$ & $\gamma$ & r & $\mathbf{Y}$ \\
\hline Year Fa & $\mathrm{N}$ & $y$ & $n$ & $\dot{\gamma}$ & $\gamma$ & $\dot{\gamma}$ \\
\hline Community trends & $n$ & N & $\mathbf{N}$ & N & $\dot{Y}$ & $\gamma$ \\
\hline
\end{tabular}

Notes: We construct a cell-year level panel dataset for 1982-2010 for all communities, with regressions weighted by the inverse of number of cells in each community. There are 18,049 cells in the sample. To reflect a deforestation monitoring environment strengthened by enhanced satellite technology, we interact a post-2004 indicator with the demarcation treatment (Columns 1 and 2) and with the demarcation p enforcement treatment (Columns 3 and 4). Community fixed effects are included in all models, linear year effects in Columns 1 and 3 , and year fixed effects in Columns 2 and 4. Columns 5 and 6 include community-specific linear trends. We use two-way clustering of standard errors by community and year for all models.

$* \mathrm{p}<0.05 . * * \mathrm{p}<0.01 .{ }^{* * *} \mathrm{p}<0.001$

\footnotetext{
${ }^{80}$ The estimates also suggest that our null results are not likely due to confounding demarcation treatment with enforcement improvements among our comparison observations. Even in the pre-2004 window (when comparison observations were not yet benefitting from improved enforcement) we find no statistically significant effects of demarcation status.
} 
Figure 18. Demarcated versus not demarcated

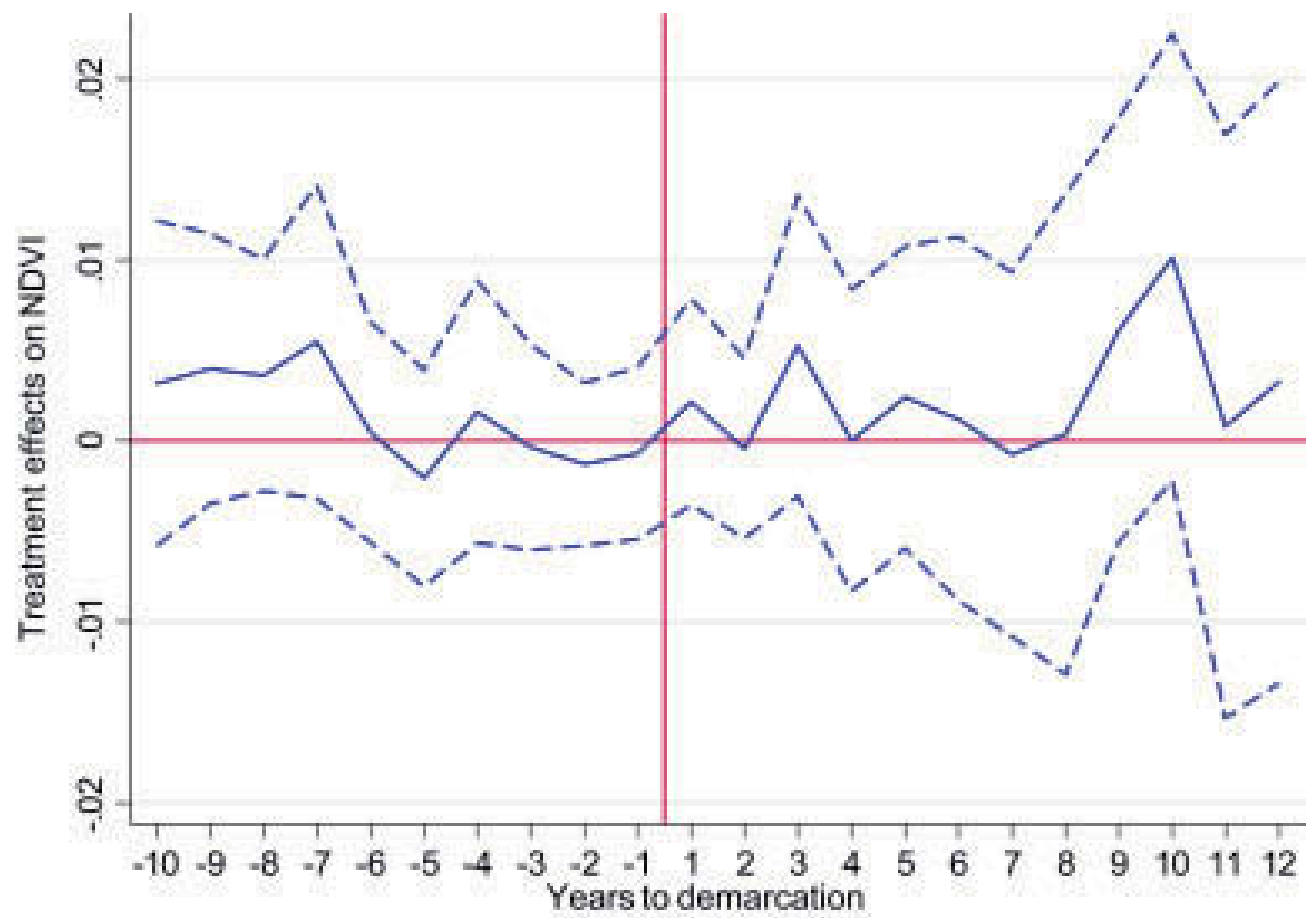

Notes: Solid line indicates treatment effect estimated for each year-to-demarcation (whole year bins), while dashed lines indicate 95 percent confidence intervals. Treatment effects are estimated using cell-year level data (weighted by inverse of count of cells in each community) with grid cell fixed effects, year fixed effects, and temperature and precipitation controls. Two-way clustering of standard errors by community and year.

As noted in the introduction, forest protection benefits are likely to accrue over time rather than as an instantaneous and constant response to treatment. To understand the time path of impacts, we estimate time-varying treatment effects as coefficients on dummies indicating the number of years post-treatment (binned by whole years). The results, shown graphically in Figure 18, illustrate that there are small positive effects beginning shortly after post-demarcation, but these effects are both very small in magnitude (generally smaller than 0.01 NDVI points) and not statistically different from zero. Just as importantly, we do not observe temporal dynamics that indicate any delayed, non-linear, or cumulative treatment effects.

\subsubsection{Community-Level Changes}

Our estimated treatment effects in the panel structure rely on each community's specific year of demarcation for identification. We also consider a less restrictive approach that assesses the differences in NDVI across communities whose rights were formalized and those whose rights 
were not formalized (without relying on the community's year of demarcation). While project records indicate that the timing of the primary treatment was sharp, this specification nonetheless allows for potential fuzziness in the timing associated with other (unobserved) benefits that occurred either before or after the actual demarcation, as well as any project-wide benefits that began accruing to all demarcated communities simultaneously. We compare formalized communities to a subset of the communities that PPTAL pre-identified but did not prioritize for formalization.

One natural concern is the potential bias due to selection of communities into the program. We employ propensity score matching that accounts for observable differences between these sets of communities to mitigate this concern. To do so, we match communities based on pre-program levels and trends in NDVI, as well as covariates (land area, population, slope, elevation, distance to the closest river and road, and pre-program levels and trends in temperature and precipitation). All variables are aggregated to the community level. The first-stage estimation results are shown in Table 16. Faster drops in minimum precipitation, faster rises in minimum temperature, and higher levels of maximum NDVI are associated with higher probability that a community will be formalized by PPTAL. The latter point is particularly important, suggesting that nonformalized communities were somewhat greener at baseline. As our aim is to estimate the propensity based on as many observable characteristics as feasible, it is not surprising that many individual covariates are not significant. 
Table 16. First-stage results

\begin{tabular}{|c|c|}
\hline \multicolumn{2}{|l|}{ Ever demarcated } \\
\hline \multirow[t]{2}{*}{ Pre-trend min precipitation } & -0.981 \\
\hline & $(0.380)$ \\
\hline \multirow{2}{*}{ Pre-trend mean precipitation } & 0.791 \\
\hline & $(0.512)$ \\
\hline \multirow{2}{*}{ Pre-trend max precipitation } & -0.005 \\
\hline & $(0.215)$ \\
\hline \multirow[t]{2}{*}{ Pre-trend mean temperature } & -11.296 \\
\hline & $(51.351)$ \\
\hline \multirow[t]{2}{*}{ Pre-trend min temperature } & 62.561 \\
\hline & $(25.838)$ \\
\hline \multirow[t]{2}{*}{ Pre-trend max temperature } & -7.254 \\
\hline & $(18.303)$ \\
\hline \multirow[t]{2}{*}{ Pre-trend NDVI mean } & -171.478 \\
\hline & $(279.370)$ \\
\hline \multirow[t]{2}{*}{ Pre-trend NDVI max } & 97.69 \\
\hline & $(93.568)$ \\
\hline \multirow[t]{2}{*}{ Max NDVI baseline } & 9.427 \\
\hline & $(3.568)$ \\
\hline \multirow[t]{2}{*}{ Population baseline } & -0.231 \\
\hline & $(0.129)$ \\
\hline \multirow[t]{2}{*}{ Mean temperature baseline } & 0.29 \\
\hline & $(0.537)$ \\
\hline \multirow[t]{2}{*}{ Mean precipitation baseline } & 0.01 \\
\hline & $(0.019)$ \\
\hline \multirow[t]{2}{*}{ Area (hectares) } & 0.000 \\
\hline & $(0.000)$ \\
\hline \multirow[t]{2}{*}{ Slope } & -0.674 \\
\hline & $(0.648)$ \\
\hline \multirow[t]{2}{*}{ Elevation } & 0.002 \\
\hline & $(0.005)$ \\
\hline \multirow[t]{2}{*}{ Distance to river } & 0.0002 \\
\hline & $(0.001)$ \\
\hline \multirow[t]{2}{*}{ Distance to road } & 0.000 \\
\hline & $(0.000)$ \\
\hline \multirow[t]{2}{*}{ Constant } & -14.262 \\
\hline & $(14.202)$ \\
\hline Observations & 151 \\
\hline Akaike Inf. Crit. & 173.274 \\
\hline
\end{tabular}

After estimating the propensity scores, we first match communities without replacement. We are initially limited by the existence of only 45 non-formalized communities (and 106 formalized communities). We drop communities with propensity scores outside of the range of common support (0.23-0.9), leaving us with 28 pairs of treatment and control communities. Table 17 and Table 18 provide descriptive statistics for these communities, with Table 17 showing the unmatched communities and Table 18 showing these statistics for both the matched-withoutreplacement and the matched-with-replacement samples (the latter is discussed below). Our results indicate that the matching reduces the normalized difference in means considerably, 
especially for the levels of baseline NDVI in 1995. While there is some remaining imbalance among covariates, we assess the likelihood that such covariates play an important role by examining the differences in our main estimates in the unmatched and matched samples.

Figure 19. Demarcated versus never demarcated

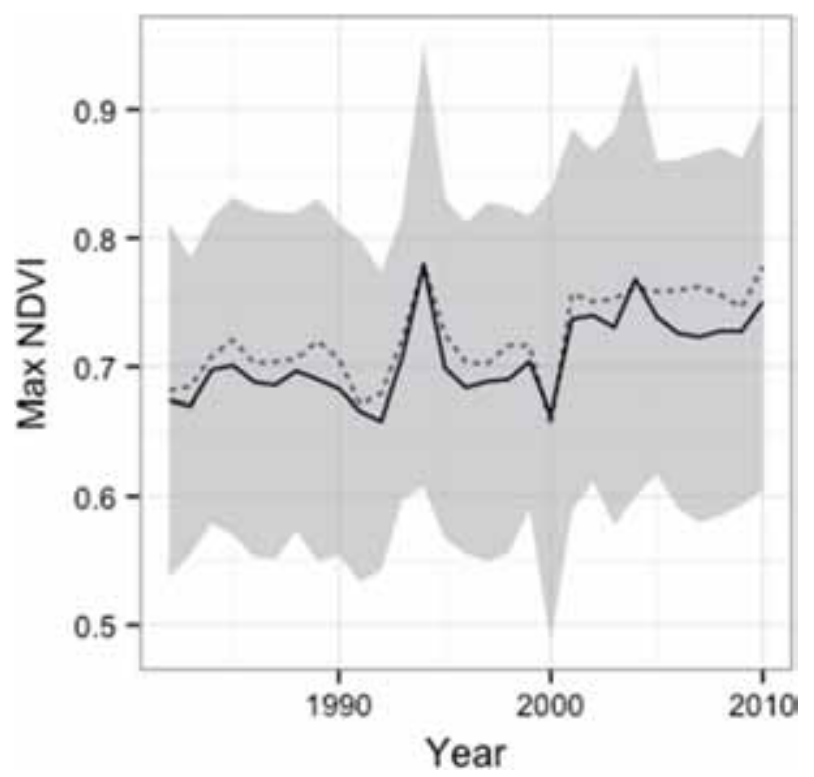

Notes: Dashed line indicates mean of all demarcated communities, while solid line indicates mean of never demarcated communities. Gray shading indicates 95 percent confidence interval for never demarcated communities.

Figure 19 shows the changes in NDVI levels from 1982 to 2010 comparing the averages for the matched pairs of communities that were demarcated and those not. In this raw annual time series, there are considerable fluctuations due to temperature, precipitation, and other time variations. However, we find little evidence of a divergence between treatment and comparison communities. 
Table 17. Summary statistics, unmatched communities

\begin{tabular}{|c|c|c|c|c|}
\hline & & Unmat & ommunities & \\
\hline & All communities & $\begin{array}{l}\text { Never } \\
\text { demarcated }\end{array}$ & Ever demarcated & $\begin{array}{l}\text { Normalized } \\
\text { difference in } \\
\text { means }\end{array}$ \\
\hline $\mathbf{N}$ & 151 & 45 & 106 & \\
\hline Area (hectares) & $320,600.10$ & $207,207.60$ & $368,738.50$ & 0.153 \\
\hline Elevation (m) & 138.493 & 164.868 & 127.296 & 0.353 \\
\hline $\begin{array}{l}\text { Mean } \\
\text { precipitation, } \\
1995\end{array}$ & 162.404 & 158.363 & 164.119 & 0.231 \\
\hline $\begin{array}{l}\text { Mean } \\
\text { temperature, } \\
1995\end{array}$ & 24.487 & 24.268 & 24.58 & 0.395 \\
\hline NDVI max, 1995 & 0.717 & 0.699 & 0.725 & 0.38 \\
\hline $\begin{array}{l}\text { NDVI mean, } \\
1995\end{array}$ & 0.283 & 0.293 & 0.279 & 0.461 \\
\hline $\begin{array}{l}\text { Population } \\
\text { density, } 1990\end{array}$ & 1.467 & 1.846 & 1.306 & 0.291 \\
\hline $\begin{array}{l}\text { River distance } \\
\text { (m) }\end{array}$ & $1,760.30$ & $1,736.24$ & $1,770.51$ & 0.091 \\
\hline $\begin{array}{l}\text { Road distance } \\
\text { (m) }\end{array}$ & $98,965.35$ & $81,722.54$ & $106,285.40$ & 0.221 \\
\hline Slope (deg.) & 0.708 & 0.813 & 0.664 & 0.338 \\
\hline
\end{tabular}


Table 18. Summary statistics, matched communities

\begin{tabular}{|c|c|c|c|c|c|c|}
\hline & \multicolumn{3}{|c|}{$\begin{array}{c}\text { Matched communities, without } \\
\text { replacement }\end{array}$} & \multicolumn{3}{|c|}{$\begin{array}{l}\text { Matched communities, with } \\
\text { replacement }\end{array}$} \\
\hline & $\begin{array}{l}\text { Never } \\
\text { demarcated }\end{array}$ & $\begin{array}{l}\text { Ever } \\
\text { demarcated }\end{array}$ & $\begin{array}{l}\text { Normalized } \\
\text { difference } \\
\text { in means }\end{array}$ & $\begin{array}{l}\text { Never } \\
\text { demarcated }\end{array}$ & $\begin{array}{l}\text { Ever } \\
\text { demarcated }\end{array}$ & $\begin{array}{l}\text { Normalized } \\
\text { difference } \\
\text { in means }\end{array}$ \\
\hline $\mathbf{N}$ & 28 & 28 & & 24 & 78 & \\
\hline $\begin{array}{l}\text { Area } \\
\text { (hectares) }\end{array}$ & $126,790.90$ & $259,563.80$ & 0.125 & $144,450.70$ & $319,925.20$ & 0.166 \\
\hline Elevation (m) & 102.755 & 111.154 & 0.079 & 103.239 & 123.332 & 0.189 \\
\hline $\begin{array}{l}\text { Mean } \\
\text { precipitation, } \\
1995\end{array}$ & 168.82 & 163.711 & 0.205 & 170.263 & 164.74 & 0.222 \\
\hline $\begin{array}{l}\text { Mean } \\
\text { temperature, } \\
1995\end{array}$ & 24.711 & 24.68 & 0.039 & 24.695 & 24.536 & 0.201 \\
\hline $\begin{array}{l}\text { NDVI max, } \\
1995\end{array}$ & 0.716 & 0.708 & 0.123 & 0.713 & 0.73 & 0.242 \\
\hline $\begin{array}{l}\text { NDVI mean, } \\
1995\end{array}$ & 0.283 & 0.279 & 0.135 & 0.28 & 0.28 & 0.001 \\
\hline $\begin{array}{l}\text { Population } \\
\text { density, } \\
1990\end{array}$ & 1.948 & 1.926 & 0.012 & 1.535 & 1.485 & 0.027 \\
\hline $\begin{array}{l}\text { River } \\
\text { distance (m) }\end{array}$ & $1,770.79$ & $1,669.49$ & 0.268 & $1,792.01$ & $1,786.43$ & 0.015 \\
\hline $\begin{array}{l}\text { Road } \\
\text { distance }(\mathrm{m})\end{array}$ & $105,356.00$ & $124,691.40$ & 0.174 & $115,745.80$ & $104,955.10$ & 0.097 \\
\hline Slope (deg.) & 0.729 & 0.724 & 0.012 & 0.713 & 0.653 & 0.137 \\
\hline
\end{tabular}

We estimate the program impacts on the long changes in NDVI by constructing our outcome variable as the difference between the baseline level of deforestation (in 1995) and the level of deforestation during the final year of the interval. ${ }^{81}$ Our estimating equation is thus ${ }^{82}$

\footnotetext{
${ }^{81}$ Results are qualitatively similar when the outcome variable is the change in the rate of deforestation between the pre-program and post-program periods.

${ }^{82}$ Under 'NDVI,' we capture biomass as a proxy for environmental conservation or deforestation. By ' $\mathrm{T}$ ' we understand treatment, or land demarcation where communities receive support, such as GPS mapping, boarders,
} 
$\Delta N D V I_{i p}=\alpha+\beta T_{i p}+\theta_{1} N D V I_{i p 1995}+\theta_{2} \Delta N D V I_{i p 1982,1995}+\Gamma X_{i p}+D_{p}+\epsilon_{i p}$

where $T_{i p}$ is an indicator of treatment for community i in matched pair $\mathrm{p}, D_{p}$ is a set of dummies for matched pairs, $X_{i p}$ is a vector of controls, $N D V I_{i p 1995}$ is the pre-treatment level for the community and $\triangle N D V I_{i p 1982,1995}$ is the pre-trend between 1982 and the last pre-treatment year.

Because matching without replacement is constrained by the smallest sample in either group (in our case, only 28 comparison units available in the common support), we also conduct matching with replacement. In this case, we estimate effects for a trimmed sample of 78 formalized and 24 comparison communities (with the remaining 28 formalized communities falling outside the range of common support). When we do so, we employ inverse propensity score weighting (IPW) in our regressions to account for the many-to-one matching of treatment units to comparison units (as well as the propensity scores themselves). We thus omit matched pair dummies and instead conduct weighted least-squares estimation.

Table 19 displays regression results estimating the treatment effects, first in the full (unmatched) sample and then in each of our matched samples. Column 1 presents treatment effects in the unmatched sample without additional covariates, showing a very small and insignificant estimate. Column 2 adds covariates to the model and again shows a limited and insignificant relationship between treatment status and NDVI. In Column 3, we estimate impacts in our matched pair sample of 56 communities without covariates, finding notably larger but not significant effects. We find opposite-signed but again insignificant effects when adding covariates in Column 4. Columns 5 and 6 estimate the IPW regressions in our trimmed, matchedwith-replacement sample. We find effects that are quite small and not statistically different from zero. These results are not limited by insufficient precision: standard errors are sufficiently small to detect changes of roughly 2.2 percent of baseline levels. Given that the matching exercises substantially reduce the differences in covariates across the groups, the similarity in results with both the unmatched and matched samples suggests that selection on these covariates is not biasing our findings. The limited response of the treatment effects to sample construction and covariate adjustment indicate there is little support to the idea that there are substantial impacts whose timing diverged from the year of demarcation. While matching does not eliminate all 
differences in all covariates, our estimates remain little changed when matching, suggesting that further covariate balancing is unlikely to alter our results.

Table 19. Community-level long changes

\section{Regression Results}

\begin{tabular}{|c|c|c|c|c|c|c|}
\hline & \multicolumn{6}{|c|}{ Dependent variable: } \\
\hline & \multicolumn{6}{|c|}{ Max NDVI $1995-2010$} \\
\hline & (1) & (2) & (3) & (4) & (5) & (6) \\
\hline Treatment & $\begin{array}{c}0.002 \\
(0.009)\end{array}$ & $\begin{array}{c}0.012 \\
(0.008)\end{array}$ & $\begin{array}{c}0.013 \\
(0.012)\end{array}$ & $\begin{array}{c}-0.005 \\
(0.009)\end{array}$ & $\begin{array}{c}0.017 \\
(0.011)\end{array}$ & $\begin{array}{c}0.013 \\
(0.009)\end{array}$ \\
\hline Pre-Trend NDVI & & $\begin{array}{c}-5.848^{* * *} \\
(1.394)\end{array}$ & & $\begin{array}{l}-2.194 \\
(3.025)\end{array}$ & & $\begin{array}{c}-5.066^{* * *} \\
(1.631)\end{array}$ \\
\hline Baseline NDVI & & $\begin{array}{c}-0.166^{* \ldots *} \\
(0.055)\end{array}$ & & $\begin{array}{c}-0.437^{* *} \\
(0.180)\end{array}$ & & $\begin{array}{c}-0.333^{* *} \\
(0.076)\end{array}$ \\
\hline Area (hectares) & & $\begin{array}{c}0.000 \\
(0.000)\end{array}$ & & $\begin{array}{c}0.000 \\
(0.00000)\end{array}$ & & $\begin{array}{l}-0.000 \\
(0.000)\end{array}$ \\
\hline Baseline Population Density & & $\begin{array}{c}0.001 \\
(0.002)\end{array}$ & & $\begin{array}{l}-0.002 \\
(0.004)\end{array}$ & & $\begin{array}{c}-0.005^{* \bullet} \\
(0.003)\end{array}$ \\
\hline Baseline Temperature & & $\begin{array}{c}-0.001 \\
(0.007)\end{array}$ & & $\begin{array}{c}0.023 \\
(0.024)\end{array}$ & & $\begin{array}{c}0.010 \\
(0.008)\end{array}$ \\
\hline Temperature Trends & & $\begin{array}{c}0.158 \\
(0.171)\end{array}$ & & $\begin{array}{c}0.620 \\
(0.475)\end{array}$ & & $\begin{array}{l}-0.096 \\
(0.215)\end{array}$ \\
\hline Precipitation Trends & & $\begin{array}{c}0.024^{* * *} \\
(0.005)\end{array}$ & & $\begin{array}{l}0.026^{* *} \\
(0.012)\end{array}$ & & $\begin{array}{l}0.015^{* *} \\
(0.006)\end{array}$ \\
\hline Baseline Precipitation & & $\begin{array}{l}0.00003 \\
(0.0002)\end{array}$ & & $\begin{array}{c}-0.002^{* * *} \\
(0.001)\end{array}$ & & $\begin{array}{l}-0.0002 \\
(0.0003)\end{array}$ \\
\hline Slope & & $\begin{array}{c}-0.004 \\
(0.010)\end{array}$ & & $\begin{array}{c}0.024 \\
(0.033)\end{array}$ & & $\begin{array}{l}-0.002 \\
(0.012)\end{array}$ \\
\hline Elevation & & $\begin{array}{c}0.0002^{* * *} \\
(0.0001)\end{array}$ & & $\begin{array}{c}0.0003 \\
(0.0003)\end{array}$ & & $\begin{array}{c}0.0003^{* *} \\
(0.0001)\end{array}$ \\
\hline Distance to River & & $\begin{array}{l}-0.00000 \\
(0.00001)\end{array}$ & & $\begin{array}{l}-0.00003 \\
(0.00002)\end{array}$ & & $\begin{array}{c}-0.00001 \\
(0.00001)\end{array}$ \\
\hline Distance to Road & & $\begin{array}{l}-0.00000 \\
(0.00000)\end{array}$ & & $\begin{array}{c}0.00000^{* *} \\
(0.00000)\end{array}$ & & $\begin{array}{l}-0.00000 \\
(0.00000) \\
\end{array}$ \\
\hline Observations & 151 & 151 & 56 & 56 & 102 & 102 \\
\hline $\mathrm{R}^{2}$ & 0.0002 & 0.352 & 0.610 & 0.935 & 0.023 & 0.530 \\
\hline Adjusted $\mathrm{R}^{2}$ & -0.007 & 0.290 & 0.205 & 0.761 & 0.013 & 0.461 \\
\hline
\end{tabular}

Note: Columns 1-2n include the full sample of communities, while Columns 3-4 include only matched-withoutreplacement pairs. Columns 5-6 include treatment communities and matched-with-replacement controls, trimmed for a common support. 


\subsubsection{Robustness Checks}

We first assess whether our results vary when considering alternative levels of aggregation. The modifiable area unit problem could bias our estimates if the LTDR-based cells do not appropriately reflect treatment units. Moreover, the spatial configuration of community lands could obscure important treatment effects. For example, treatment might differentially protect forests near the communities' boundaries, which are at highest risk of deforestation, while interior forests remain unaffected. Such boundary effects might only be detectable using smaller cells than those offered by LTDR (which are approximately $4 \mathrm{~km} \mathrm{x} 4 \mathrm{~km}$ ). We therefore test whether both larger and smaller units of aggregation generate consistent estimates.

In Table 20, we conduct the equivalent panel analysis using community-year-level data (rather than cell-year). We find results that are quite similar to those in our cell-year-level data (Table 14 and Table 15). We also consider whether higher resolution imagery might detect treatment effects, particularly along the boundaries of the communities. GIMMS-based NDVI measures are available at $250 \mathrm{~m}$ spatial resolution beginning in the year 2000 and running until 2014. We can therefore use this dramatically higher resolution measure to test demarcation treatment effects among our later-demarcated communities. We sample 10,004 MODIS-based cells from within our community boundaries and construct an annual level panel dataset, with our timevarying climatic control variables spatially joined to these finer cells. We then implement a similar estimation, using cell-level fixed effects and weighting by the inverse of community size to avoid over-representing effects among larger communities. We employ two-way clustering of standard errors at the community and year levels to account for spatial and temporal unobservables. 
Table 20. Community-year panel model

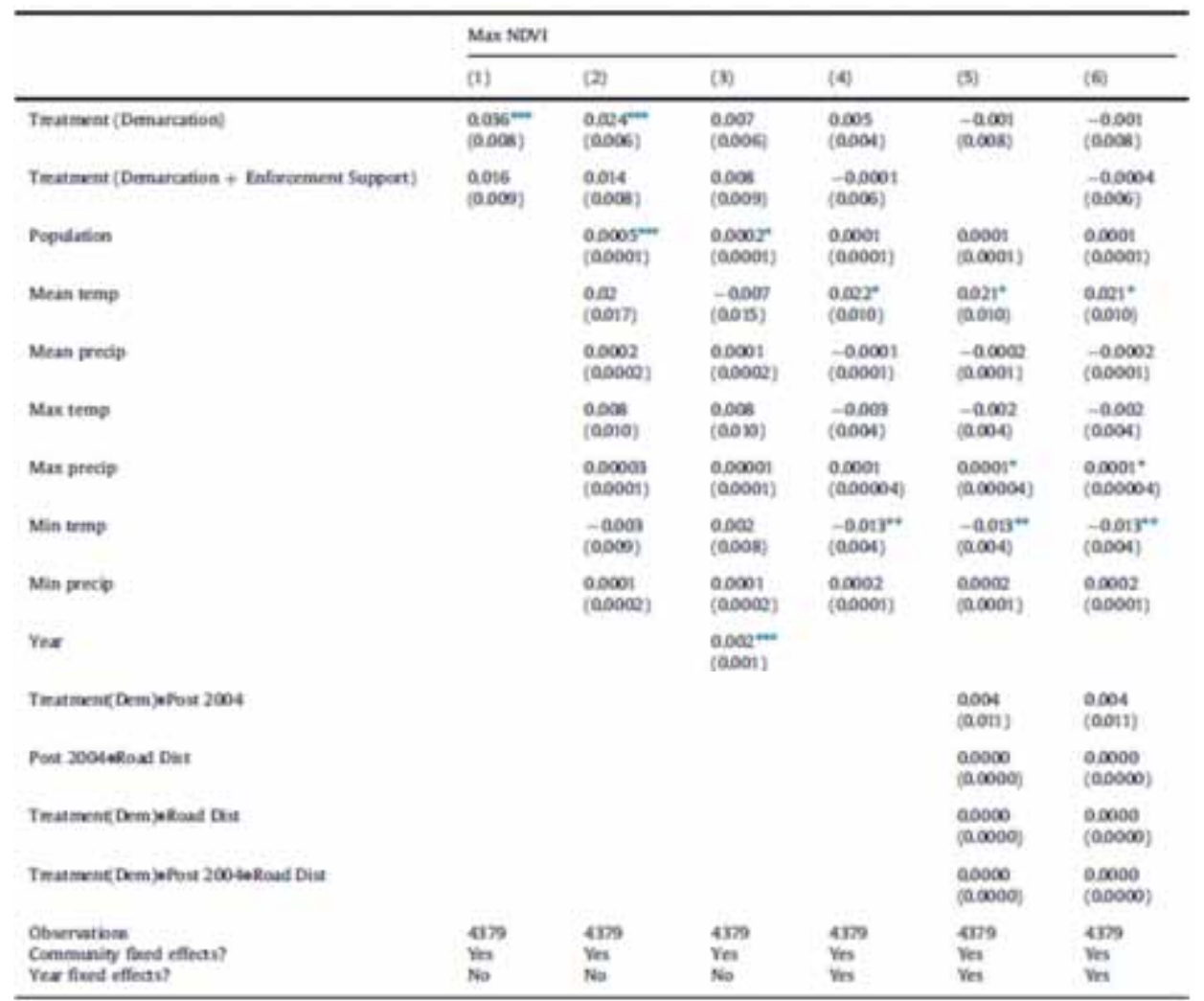

Notes: We construct a panel using community-level annual data (rather than cell level). Column 1 provides an estimation with only community-level fixed effects (and no time controls), while Column 2 adds time-varying climate and population controls. Column 3 adds linear year effects and Columns 4-6 include year fixed effects. Columns 5 and 6 add interactions with a post-2004 dummy to reflect a strengthened monitoring environment due to enhanced satellite technology, with easier enforcement of observed deforestation expected in communities of lesser distance. Column 5 examines demarcation treatment only, while Column 6 examines both demarcation and enforcement support. Two-way clustering of standard errors by community and year is used.

$\star \mathrm{p}<0.05 . \star \star \mathrm{p}<0.01 . \star \star \star \mathrm{p}<0.001$.

The results, shown in Table 21, indicate that greenness does appear to improve following demarcation, but only very minimally. Once we account for year-specific fixed effects in Column 4 , treatment effects are approximately 1.04 NDVI points, roughly 0.5 percent of the sample mean and 0.04 standard deviations units on the GIMMS scale (note the support of GIMMS-based NDVI is $0-250$ and its sample SD $1 / 423.4$; summary statistics are reported in Table 21). 
Table 21. Summary statistics for GIMMS grid cell-level panel, weighted by community size

\begin{tabular}{|c|c|c|c|c|}
\hline Seatatk & Man & 2. Der & Nan & $\mathrm{M}=$ \\
\hline Drration (m) & 13ass & nori & 222 & mons \\
\hline 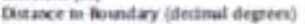 & aove & abes & abocet $t$ & ans. \\
\hline 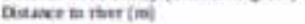 & zan193 & เงตง & abo & anter \\
\hline Duture he rad (in) & $\operatorname{sen} 3 x$ & orat & 2225 & 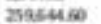 \\
\hline sope (tes) & arn & $\operatorname{axn}$ & abo & 20.4i \\
\hline Nos (heatern) & 1027530 & sonike & a.oo & ishanow \\
\hline Mean tringraturs & $x=4$ & ass & $21 \mathrm{MS}$ & Dass \\
\hline Mean ymciputhe & 10064 & D.44 & TL187 & $300=6$ \\
\hline Man enequate & mas & $\sin$ & nass & 10)44 \\
\hline Sta prectpitatian & mises & enas & saise & $\cos 225$ \\
\hline Mhe temperation & $2 \mathrm{n} n$ & 12ss. & ais6 & 27302 \\
\hline Mhe pencipuatios & 45.929 & seis: & aoo & 21059 \\
\hline Now & miser & $20 \% 5$ & 100 & 24323 \\
\hline Reclatien sumily & 272 & 221 & a.oo & 22202 \\
\hline
\end{tabular}

These effects are not statistically significant but are reasonably precisely estimated (the minimum detectable treatment effect in this estimation would be $0.55 \%$ of the sample mean). We then interact the treatment status with the cell's distance from the boundary of the community in which it falls, with results in Column 5. Treatment effects among cells closest to the boundary (where the distance is effectively 0 ) are 1.05 NDVI points, nearly identical to the average treatment effects across all cells. Such effects could still be understated if the interaction is highly nonlinear in distance from the boundary. We therefore categorize cells as being "close" to the boundary (within $5 \mathrm{~km}$ ) or "far" (beyond $5 \mathrm{~km}$ ) from the boundary. The point estimate of treatment effects among cells close to the border remain quite similar, roughly $1.065 \mathrm{NDVI}$ points. Thus, using high resolution imagery to detect changes among the portions of community lands at greatest risk, we observe only relatively small and noisy effects. 
Table 22. GIMMS cell-year panel, weighted by community size

\begin{tabular}{|c|c|c|c|c|c|c|}
\hline & \multicolumn{6}{|l|}{ Mexsevs } \\
\hline & a) & (2) & a) & (4) & क) & (6) \\
\hline Theatmone (Denarraciane & $\begin{array}{l}-1.400 \% \\
\text { sosuen }\end{array}$ & 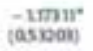 & 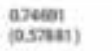 & $\begin{array}{l}1043 x \\
\text { p.chomi) }\end{array}$ & $\begin{array}{l}10025 \\
\text { (0.50) }\end{array}$ & $\begin{array}{l}\text { Iasus } \\
\text { gocoun }\end{array}$ \\
\hline Mens terro & & $\begin{array}{l}\text { a.s72x } \\
\text { (a.min) }\end{array}$ & $\begin{array}{l}-0.4365 \\
\text { a.946mis }\end{array}$ & $\begin{array}{l}-134682 \\
\text { [a.79361] }\end{array}$ & $\begin{array}{l}-134653 \\
\text { a.mece }\end{array}$ & $\begin{array}{l}\text {-tsies? } \\
\text { p.79ak? }\end{array}$ \\
\hline Mean intcip & & 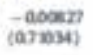 & $\begin{array}{l}\operatorname{ascosa} \\
10.00 \mathrm{nin})\end{array}$ & 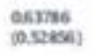 & $\begin{array}{l}\text { acason } \\
\text { assmen }\end{array}$ & $\begin{array}{l}\text { acasos } \\
\text { fosioon }\end{array}$ \\
\hline Me temp & & $\begin{array}{l}\text {-axpeas } \\
\text { (asivica) }\end{array}$ & $\begin{array}{l}\text { aevos } \\
\text { [0.e125] }\end{array}$ & $\begin{array}{l}\text { afron } \\
\text { (9.452) }\end{array}$ & $\begin{array}{l}\text { a.azn } \\
\text { (b.as20an }\end{array}$ & 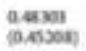 \\
\hline Man anctp & & 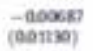 & $\begin{array}{l}\text { aboxn } \\
\text { poasty }\end{array}$ & $\begin{array}{l}\text { aboss: } \\
\text { paom? }\end{array}$ & $\begin{array}{l}\text { acossa } \\
\text { pooned }\end{array}$ & $\begin{array}{l}\text { acoss } \\
\text { (p.000\%) }\end{array}$ \\
\hline Matern & & (abcosa) & $\begin{array}{l}-0.00201 \\
0.006 x 2 y\end{array}$ & $\begin{array}{l}\text { eoczss } \\
\text { comes }\end{array}$ & $\begin{array}{l}\text { acozss } \\
\text { gobuson }\end{array}$ & $\begin{array}{l}\text { acosss } \\
\text { (0.aszm }\end{array}$ \\
\hline Mu parip & & $\begin{array}{l}\text { apose } \\
\text { [00016) }\end{array}$ & $\begin{array}{l}\text { ac01so } \\
\text { (0.00050) }\end{array}$ & $\begin{array}{l}\text { coomi } \\
\text { abowon }\end{array}$ & $\begin{array}{l}\text { a.0001 } \\
\text { [0.6050\%] }\end{array}$ & 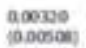 \\
\hline Wear & & & $\begin{array}{l}-0.839 y^{*-1} \\
\text { pass4e }\end{array}$ & & & \\
\hline 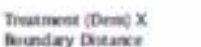 & & & & & $\frac{a x b m}{48 \mathrm{gen}}$ & \\
\hline Pratinens (Ders) $\mathrm{x}$ & & & & & & -0.0sesa \\
\hline heundry Diesere (Cat) & & & & & & (0.50024) \\
\hline Ohiervating & 100033 & 14aอss & 100 as & Iอas & 10033 & 10003 \\
\hline Cril Fent Eflloss? & $\operatorname{trn}$ & Yen & Ven & Wen & m & $y_{m}$ \\
\hline Yeer Fand Ellong & Nin & tis & $\mathrm{Nu}$ & We & m & $\mathrm{min}$ \\
\hline
\end{tabular}

Notes: We construct a cell-year level panel dataset for 2000-2014 for all communities that were demarcated 2002 and later. The unit of analysis is a point selected randomly within demarcated communities, and the max NDVI at each point is measured with GIMMS $250 \mathrm{~m}$ resolution data. Column 1 shows estimation of a model with only cell-level fixed effects (and no time controls), while Column 2 adds time-varying climate and population controls. Column 3 adds linear year effects as a control and Column 4 incorporates year-specific fixed effects. Column 5 adds an interaction between treatment and the distance from each point to the community's boundary. Column 6 uses a categorical variable of the distance to the community's boundary. Columns 4-6 include cell and yearspecific fixed effects. We use two-way clustering of standard errors by community and year for all models. All models are weighted by community size.

$\star \mathrm{p}<0.05 . \star \star \mathrm{p}<0.01 . \star \star \star \mathrm{p}<0.001$.

Finally, we assess whether our results are driven by the construction of our outcome measure into an annual aggregate from monthly data. While the annual maximum NDVI $20^{83}$ has been shown to correlate with vegetative productivity (Pettorelli et al. 2005), it may also be sensitive to outlier observations and thereby obscure the program's true impacts. We thus return to our community-level data and instead employ the annual median of monthly NDVI as an alternative outcome measure in Table 23, again finding results that are largely similar.

\footnotetext{
${ }^{83}$ In the remote sensing field, this approach is often termed "maximum value compositing" (Pettorelli et al. 2005).
} 
Table 23. Never versus ever demarcated, median NDVI

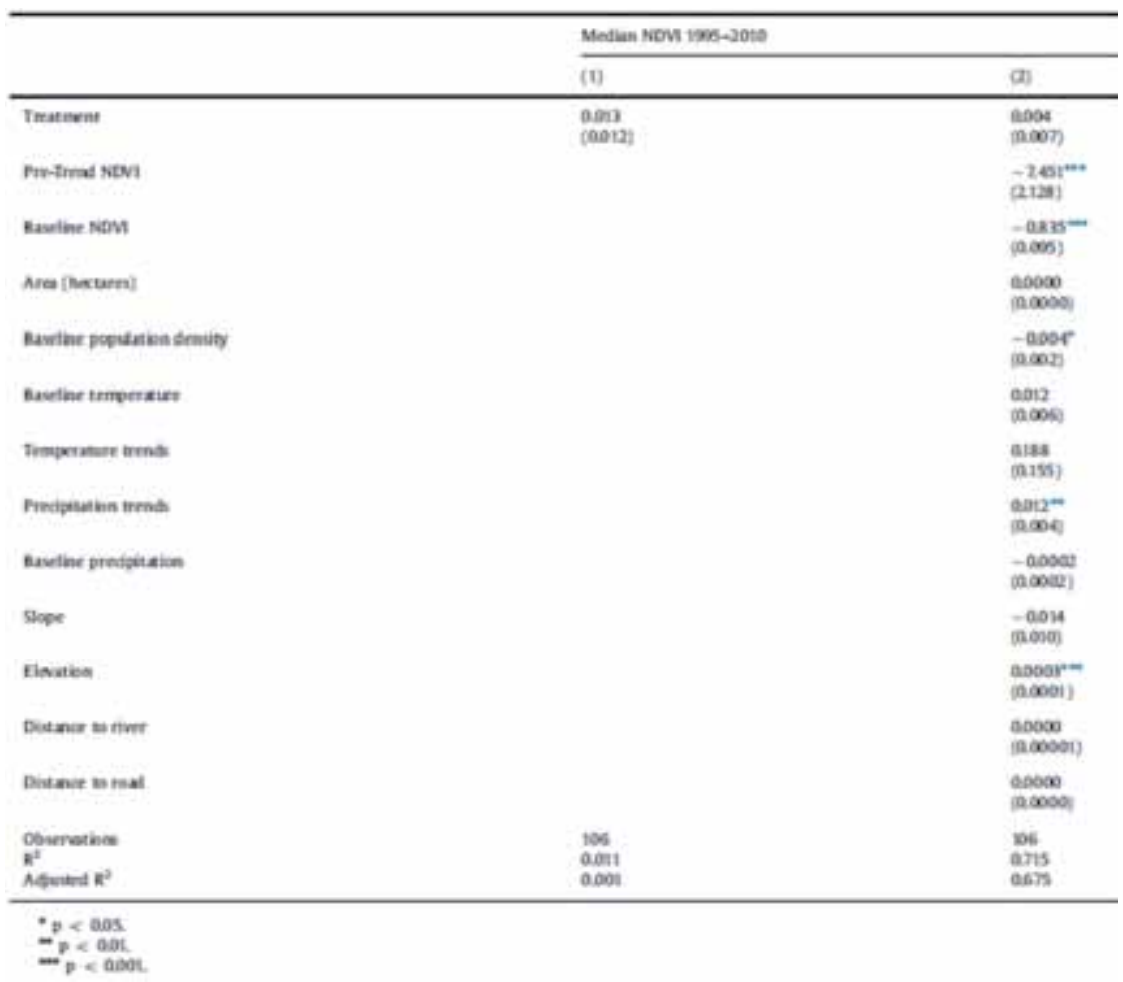

\subsection{CONCLUSIONS}

Using a varied set of empirical approaches, we find no evidence that formalizing indigenous land rights or supporting surveillance and enforcement by the communities in our sample impacted deforestation during the study period. We observe no statistically distinguishable effects from the treatments implemented through PPTAL. Using both within-treatment group comparisons based on the timing of treatment and cross-group comparisons with untreated but similar lands, we obtain similar null results. These null results are not due to imprecision; using grid cell-year level outcomes that are stripped of climatic fluctuations, we could detect effects that are $0.8 \%$ of the sample mean forest greenness.

Nonetheless, these results should be considered in the broader context of deforestation pressures on indigenous lands in the Brazilian Amazon. It is worth reiterating that our measure of deforestation, NDVI, seems to be relatively stable during the 1982-2010 period for these communities (to the extent we observe any average changes over the time period, NDVI is 
increasing, indicating reforestation). This is consistent with other evidence that the deforestation rate on indigenous lands has, on average, remained quite low. This does not indicate that deforestation did not occur in the Amazon region during this time, or within some of the selected communities (as indeed, Pfaff et al. 2015 show), but rather that the overall rate of deforestation among the project communities was relatively low. In other words, many indigenous communities did not face as great a deforestation threat as often feared - an encouraging result. Moreover, it is possible that deforestation pressures among indigenous communities in the Amazon will increase in the coming decades, and that PPTAL's impacts will be felt at that point.

Lastly, because PPTAL was partly driven by constitutional, human rights, and well-being concerns for the rights of indigenous communities, the lack of deforestation impacts does not imply the program was unsuccessful on these other dimensions. At the same time, we now have more evidence about the mix of policy interventions that help combat deforestation in Brazil specifically and more broadly than what was available in 1995, when the PPTAL project was launched. Among these policies are investments in monitoring technology and enforcement efforts (Hargrave and Kis-Katos 2013, Arima et al. 2014, Assunção et al. 2014, Börner et al. 2014, Börner et al. 2015), Payments for Ecosystem Services (Börner et al. 2010), and interventions in the beef and soy bean supply chains (Nepstad et al. 2014). Moreover, there is also better data available on the deforestation rates in individual community lands. While PPTAL did attempt to prioritize lands for demarcation based on their risks, available data appear to have been coarse and potentially inconsistent. Thus, future programs aimed at avoiding deforestation and other conservation outcomes on indigenous lands may be better positioned to target scarce resources to communities under high deforestation pressure.

\subsection{Policy Relevance In The ConteXt OF THIS DisSertation}

I would like to draw the reader's attention to two findings from the above published article that are especially interesting in the context of this dissertation. Earlier we say, "there are small positive effects beginning shortly after post-demarcation, but these effects are both very small in magnitude (generally smaller than 0.01 NDVI points) and not statistically different from zero. Just as importantly, we do not observe temporal dynamics that indicate any delayed, non-linear, or cumulative treatment effects."

One of the reasons we are not seeing any effect of demarcation on forest preservation is that both demarcated and non-demarcated communities are remote and not yet threatened by deforestation. 
Using geospatial data and impact evaluation methodology, we were able to answer our second research question "what has been the effect of demarcating indigenous territories on forest preservation?" According to our estimates, there has not been an effect of demarcation on forest preservation.

Our contribution to the literature was that we explored a novel dataset produced during the implementation of the Indigenous Lands Project about formalizing indigenous land rights. This was the first time that researchers have compared demarcated with non-demarcated communities and estimated the effect of demarcation on forest preservation using a large sample of indigenous territories.

In chapter four, I will widen the perspective and examine other environmental policies and their effect on deforestation. 



\section{COMPARING EFFECTS OF INDIVIDUAL ENVIRONMENTAL POLICIES}

My quest to identify factors that explain how annual deforestation in the Brazilian Amazon forest declined so fast led me to focus on a single environmental policy, demarcating indigenous territories. Using geospatial data and impact evaluation methodology, I found no statistically significant effect of demarcation on forest preservation. Here I expand the analysis to a number of environmental policies in the Brazilian Amazon and compare effect sizes from six published papers. These papers estimated the effect of different environmental policies on deforestation using quasi-experimental evaluation techniques.

Forests are an important carbon sink. However, they can also turn into a carbon source with deforestation and forest degradation (Baccini et al. 2017, Asner 2017). Brazil is the country with the most tropical forest in the world. According to Van der Werf et al. (2009), deforestation is one of the largest sources of anthropogenic carbon dioxide emissions in the atmosphere, topped only by fossil fuel combustion. Thus, tropical forests, historically a net sink of carbon, have recently evolved into a net source of carbon due to deforestation and forest degradation (Baccini et al. 2017). Between 2001 and 2010, the Amazon forest alone was responsible for $4.2 \mathrm{Gt}$ (gigatons) of $\mathrm{CO}_{2}$ emissions equivalent due to deforestation (Numata 2011). Huang and Asner (2010) estimated an average of $0.15-0.18 \mathrm{Gt}$ of $\mathrm{CO}_{2}$ emissions per year for the nine states of the Brazilian Amazon, likely underestimating the total amount, which was corrected by Pearson et al. (2017) estimating $0.28 \mathrm{Gt}_{\text {of }} \mathrm{CO}_{2}$ emissions per year. According to Pearson et al. (2017), Brazil ranks second worldwide after Indonesia in terms of $\mathrm{CO}_{2}$ emissions from forest degradation. Therefore, Brazil has a large responsibility for forest preservation and thus climate mitigation policies.

For about a decade, Brazil has made great strides in reducing deforestation (Figure 4). According to Nepstad et al. (2014), Brazil produced 3.2 Gt less atmospheric carbon dioxide between 2005 and 2013 than it would have in the absence of environmental policies. A 2016 World Resources Institute (WRI) study estimates that carbon storage benefits from avoided deforestation on indigenous forestlands amounts to USD14 per hectare and year in 2015 (estimated with SCC=USD41/tCO2, WRI 2016). The same report estimates that annually avoided $\mathrm{CO}_{2}$ emissions through indigenous forestland-tenure security have the potential to avoid 
31.76 $\mathrm{Mt} \mathrm{CO}_{2}$ per year, which is equivalent to $6,708,778$ passenger vehicles taken off the roads for one year (WRI 2016).

Because of the importance of forest preservation for the local and global climate and multiple environmental services, such as biodiversity and water resources, I am comparing average effect sizes of environmental policies (according to other authors in the literature), and which one of the environmental policies implemented by the Brazilian government was most effective.

I base my analysis on the results of six published articles that determined the effect of individual environmental policies on forest cover for the Brazilian Amazon. I selected these articles based on a systematic review of the literature. The resultant articles cover five environmental policies. Chapter five will cover eight environmental policies. However, I did not find any articles in the literature for the policies on rural credit restriction, the rural environmental registry (CAR), and the Soy Moratorium that met my selection criteria (described further below). In the case of rural credit restriction, Hargrave et al. (2013), for example, use availability of subsidized agricultural credit in their paper, which does not reflect the credit restriction policy discussed in chapter five and this aspect of their paper is therefore not included in chapter four. Using the methods of a systematic review, I selected those papers that used quasi-experimental evaluation designs with some form of statistical matching analysis, except for Hargrave and Kis-Katos (2013) that use a panel model. As in a systematic review, this section makes the effect sizes of each peer-reviewed article comparable to find out how the different effect sizes compare with each other and which of five different environmental policies can be deemed more effective in curbing deforestation. In addition, this comparison helps to validate the findings from chapter three in terms of the order of magnitude of the effects from land demarcation on forest preservation.

\subsection{Comparing Different EnVIronmental Policies in BraziL}

Only a few published articles have assessed the impact of environmental policies on deforestation in the Brazilian Amazon using quasi-experimental evaluation designs. Using a systematic review approach, I identified literature that used a quasi-experimental evaluation design with treatment and control groups that estimated a causal relationship of policy treatment on deforestation outcomes. I based my analysis on Börner et al. (2016) and Samii et al. (2014), who in turn followed the approach used by Puyravaud (2003). 
My research question for chapter four was: "How do environmental policies compare with each other in terms of their effect sizes?"

As explained in the beginning of this thesis, there is a rich literature analyzing economic drivers of deforestation in the Brazilian Amazon (Angelsen and Kaimowitz 1999, Geist and Lambin 2001, Armenteras et al. 2009, Nolte et al. 2013, Araújo et al. 2009, de Espindola 2012). As shown in Figure 8, half of the decline in deforestation can be explained by environmental policies and the other half by economic drivers of deforestation (Assunção et al. 2015). I want to keep in mind though that Assunção et al. (2015) used a general proxy to estimate the policy impact and not a specific one, such as protected area, or enforcement strategies as done here. The policy proxy used by Assunção et al. (2015) was the period during which the policy was issued compared to a period without environmental policies.

Here, I focus on the policy part influencing deforestation outcomes. I would like to know: Which policy is the most effective in reducing deforestation relative to the other environmental policies in Brazil based on selected literature. My contribution to the literature is to compare the different effect sizes for five individual environmental policies as identified in the literature. This will help determine the general magnitude of the effect an environmental policy had on deforestation in the Brazilian Amazon as estimated by studies using quasi-experimental designs and relying on geospatial data for estimating forest cover or deforestation. In chapter five, I will then compare eight environmental policies in one model. This will help me to determine the marginal effect of environmental policies on deforestation.

In this chapter, I compare five policies (because I did not find any articles in the literature that met my selection criteria for the three additional policies). I defined three categories for protected areas: strictly protected areas, sustainable use areas, and indigenous territories, the latter two allowing some form of sustainable use by local people. The five policies are as follows:

(1) Strictly protected areas

(2) Sustainable use areas

(3) Indigenous territories

(4) Enforcement missions

(5) Public disclosure.

The following paragraphs will explain the impact pathways according to which the policies reduce deforestation and subsequently will introduce the literature covered. 


\subsection{MeThODOLOGY}

\subsubsection{Identifying Selected Papers Using a Systematic Review Approach}

To identify papers, I used a systematic review approach. According to the Campbell Foundation, "a systematic review uses transparent procedures to find, evaluate and synthesize the results of relevant research. Procedures are explicitly defined in advance, to ensure that the exercise is transparent and can be replicated. This practice is also designed to minimize bias." ${ }^{44}$ I followed this approach, restricting results to papers using rigorous experimental or quasiexperimental designs.

In addition, I limited my search to selected papers that covered deforestation in the Brazilian Amazon using geo-spatially explicit data. The papers' outcome variable needed to measure "deforestation" and the effect needed to be determined by using rigorous quantitative methods with counterfactual analysis. Given the fact that there are no rigorous impact evaluations available, I allow for quasi-experimental designs in the papers' empirical strategy (Table 24).

Table 24. Selection Criteria for Systematic Review

\begin{tabular}{|c|c|}
\hline Type & Selection criteria \\
\hline Selected papers & Deforestation in the Brazilian Amazon (not only one state) \\
\hline Outcome & Deforestation using georeferenced data sources \\
\hline $\begin{array}{l}\text { Environmental policy } \\
\text { interventions }\end{array}$ & $\begin{array}{l}\text { (1) Strictly protected areas, (2) Sustainable use areas, (3) } \\
\text { Indigenous territories, (4) Enforcement missions, (5) Public } \\
\text { disclosure, (6) Soy Moratorium (introduced in 2006) }\end{array}$ \\
\hline Comparison & $\begin{array}{l}\text { Presence of a counterfactual area to which the policy did not } \\
\text { apply }\end{array}$ \\
\hline Study types & $\begin{array}{l}\text { Quantitative studies that use counterfactuals and spatially } \\
\text { explicit data }\end{array}$ \\
\hline Publication type & Papers published in peer-reviewed journals \\
\hline
\end{tabular}

Source: Adapted from Samii et al. 2014.

\footnotetext{
${ }^{84}$ Retrieved on June 2, 2018, from: https://campbellcollaboration.org/research-resources/writing-a-campbellsystematic-review/systemic-review.html.
} 
My search protocol included the following search strings:

Brazilian Amazon AND deforestation OR protected OR forest OR conservation OR governance OR Soy Moratorium

I used Google Scholar and the Web of Science for my searches. I limited my search to the period between 2010 and 2016, English language only, excluding citations. Because of initial results of 30,500 articles in Google Scholar, I decided to search for keywords only in the title using "allintitle," which resulted in 215 studies (Table 25). I searched for "Soy Moratorium" separately in the title, yielding 5 articles, which I reviewed in their entirety. I had to search for Soy Moratorium separately, because this was the only way to receive results for the Soy Moratorium. I included all results in a Mendeley database and reviewed titles and abstracts one by one. I reviewed 15 studies in more detail that had a promising title and abstract.

Articles covered environmental policies and deforestation and assessed deforestation in relation to agriculture, PES, fauna, socioeconomic development, forest fires, the Reducing Emissions from Deforestation and Forest Degradation program (REDD), satellite image technology and how to refine analysis, and malaria.

Similarly, with the Web of Science database, I limited the search to the period 2010 to 2016. I searched for the above-listed search string, keeping the search for the Soy Moratorium separate. The first search yielded more than one million articles. A search in the title yielded 253,810 articles. I therefore decided to limit my search in this database to the search string of "Brazilian Amazon AND deforestation," which yielded 185 articles (Table 27). I also conducted a separate search for "Soy Moratorium," which yielded 3 articles. Following Samii et al. 2014, I adapted my keyword searches to the two different databases. As with the Google search results, I reviewed title and abstract for the 185 articles and the 3 articles resulting from the Soy Moratorium search. Based on the title and abstract review, I considered 14 articles as a close match and reviewed the articles more closely considering the search criteria listed in Table 27.

Several articles covered environmental policies and deforestation. Some of them, however, focused only on a single state in the Brazilian Amazon, which led to the exclusion of the study (Sousa 2016, Rudorff et al. 2011, L'Roe et al. 2016). Again, articles focused on deforestation in relation to other research topics, such as forestry (biomass variability, forest fragmentation, fallow lands), carbon emissions, socioeconomic development, agriculture, weather patterns, 
technological advances in satellite imagery, fauna, and health. These later study interests were not considered relevant for the current context.

My search in both databases resulted in six articles, called 'selected papers' hereafter. These papers cover environmental policies and their effect on deforestation. They focused on the Brazilian Amazon. The articles used deforestation and georeferenced data sources in addition to rigorous impact evaluation methods with counterfactuals. The papers covered all five environmental policies presented earlier (1) Strictly protected areas, (2) Sustainable use areas, (3) Indigenous territories, (4) Enforcement missions, and (5) Public disclosure. They did not cover access to rural credit restrictions, the rural environmental registry (CAR), and the Soy Moratorium policies because the articles covering those policies or the way these policies were treated in the articles did not meet my selection criteria listed in Table 24.

Table 25. Keyword Search Results

\begin{tabular}{|c|c|c|}
\hline Database & Keywords & Articles \\
\hline Google Scholar & $\begin{array}{l}\text { Brazilian Amazon AND deforestation OR } \\
\text { protected OR forest OR conservation OR } \\
\text { governance } \\
\text { Soy Moratorium }\end{array}$ & 1,960 \\
\hline Google Scholar & Soy Moratorium & 1,960 \\
\hline Google Scholar & $\begin{array}{l}\text { allintitle: Brazilian Amazon AND } \\
\text { deforestation OR protected OR forest OR } \\
\text { conservation OR governance }\end{array}$ & 322 \\
\hline Google Scholar & allintitle: Soy Moratorium & 5 \\
\hline Web of Science & $\begin{array}{l}\text { Brazilian Amazon AND deforestation OR } \\
\text { protected OR forest OR conservation OR } \\
\text { governance }\end{array}$ & $1,010,918$ \\
\hline Web of Science & $\begin{array}{l}\text { Title search: Brazilian Amazon AND } \\
\text { deforestation OR protected OR forest OR } \\
\text { conservation OR governance }\end{array}$ & 253,810 \\
\hline Web of Science & $\begin{array}{l}\text { Title search: Brazilian Amazon AND } \\
\text { deforestation }\end{array}$ & 185 \\
\hline Web of Science & In title search: Soy Moratorium & 3 \\
\hline
\end{tabular}

Source: Own table 
In the next section, I will discuss the impact pathways according to which environmental policies likely affect deforestation.

\subsection{IMPACT PATHWAYS AND LiterATURE REVIEW-LINKING THE EFFECT OF AN EnVironmental Policy to Deforestation}

This section describes the theoretical impact pathways and the different mechanisms by which each of the five policies influences deforestation. Figure 20 displays the results chain according to which each environmental policy has an impact on deforestation. Chapter five will provide a more complex analysis comparing the different policies in one model.

According to the results framework (or program theory), strictly protected areas have an impact on deforestation through a regulation that provides the area with a protection status. The strictly protected area is usually managed by rangers that monitor the areas and enforce the borders. Protection and management will result in avoided deforestation. Sustainable use areas also work through regulations that allow local people to use forest resources sustainably, thereby protecting the forest. An assumption here is that the central and local government and in the case of federal protected areas, ICMBio, protect the area and deter intruders. Similarly, indigenous territories are being demarcated and officially recognized by Brazil's president, upon which indigenous people have the right to use natural resources for their traditional livelihood while also monitoring and protecting the forest, which leads to forest preservation, according to the results framework. Here again the assumption is that the IBAMA forest police and Brazil's government enforces the protection of the indigenous territories.

The law enforcement policy works through regulation, empowering IBAMA to monitor deforestation based on daily satellite pictures. Based on illegal deforestation activities and the budget, IBAMA then intervenes, confiscating chainsaws and other equipment and fining or incarcerating offenders. According to the results framework, those enforcement actions, result in offenders refrain from deforestation, thus preserving the forest. 
Figure 20. Impact pathways of five environmental enforcement and access restriction policies

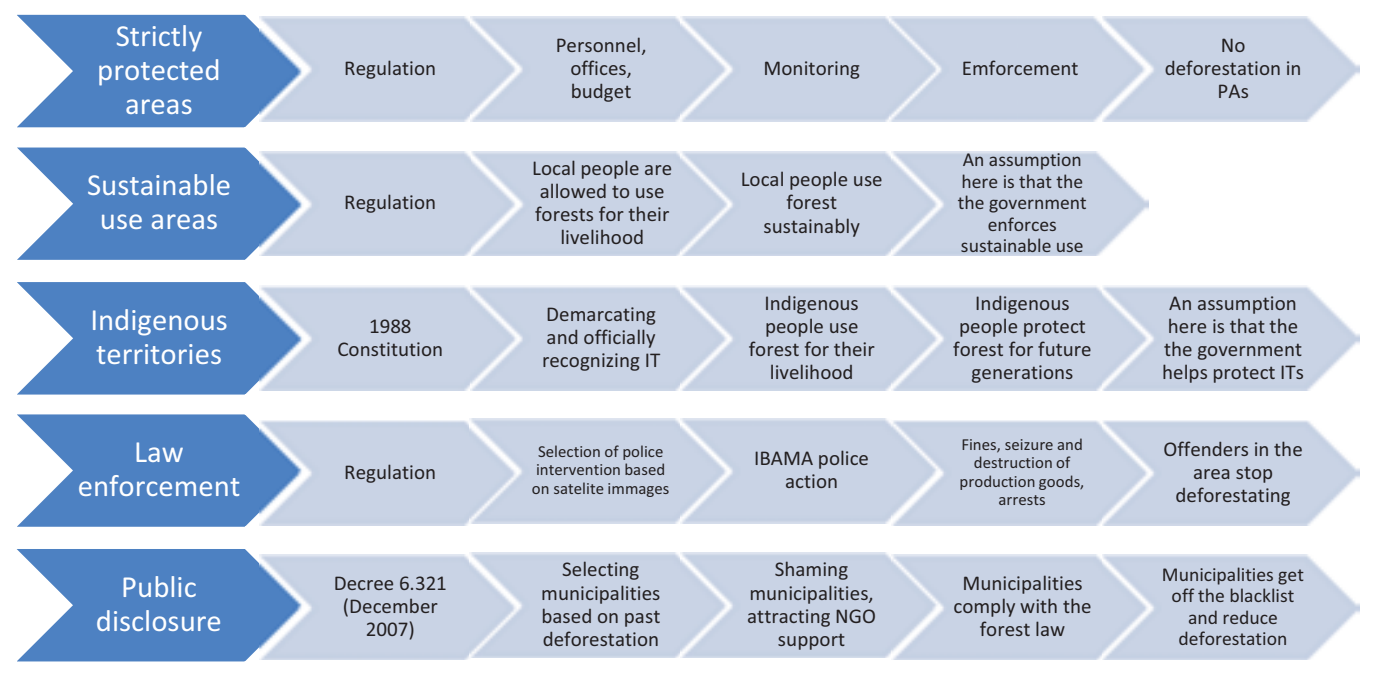

The public disclosure policy works through Decree 6.321 (from December 2007). Every year municipalities are evaluated according to three criteria: (1) What was the total area deforested? (2) What was the total area deforested within the last three years? and (3) Was there an increase in the area deforested in at least three out of the past six years? (Cisneros et al. 2015). The blacklist helps to shame municipalities into compliance with Brazil's Forest Code and for attracting NGO support to fund compliance. Thus, according to the results framework, municipalities stop deforestation and get off the blacklist.

Using a systematic review approach, I found a total of six papers analyzing the causal linkages between the different policies and deforestation (Table 26). Difficulties emerge, however, when I try to compare them. The recent literature has examined different command-and-control policies in the Brazilian Amazon using geospatial econometric methods and quasiexperimental design. Scholars estimated a positive effect for reducing deforestation for the five policy instruments. This section will describe the policy mechanism and resultant effect on deforestation as demonstrated in the literature. Here, I will review not only the six selected papers but also the broader discussion in the literature. 
Table 26. Selected papers to compare effect sizes

\begin{tabular}{|c|c|c|c|c|}
\hline No. & Author & Title & Year & Journal \\
\hline 1 & $\begin{array}{l}\text { Pfaff A., Robalino J., Herrera } \\
\text { D., Sandoval C. }\end{array}$ & $\begin{array}{l}\text { Protected Areas' Impacts on Brazilian } \\
\text { Amazon Deforestation: examining } \\
\text { conservation-development } \\
\text { interactions to inform planning }\end{array}$ & 2015 & Plos One \\
\hline 2 & $\begin{array}{l}\text { Soares-Filho B., Moutinho P., } \\
\text { Nepstad D., Anderson A., } \\
\text { Rodrigues H., Garcia R., } \\
\text { Dietzsch L., Merry F., Bowman } \\
\text { M., Hissa L., Silvestrini R, } \\
\text { Maretti C. }\end{array}$ & $\begin{array}{l}\text { Role of Brazilian Amazon protected } \\
\text { areas in climate change mitigation }\end{array}$ & 2010 & PNAS \\
\hline 3 & Hargrave J., · Kis-Katos K. & $\begin{array}{l}\text { Economic Causes of Deforestation in } \\
\text { the Brazilian Amazon: A Panel Data } \\
\text { Analysis for the } 2000 \text { s }\end{array}$ & 2013 & $\begin{array}{l}\text { Environ } \\
\text { Resource } \\
\text { Economics }\end{array}$ \\
\hline 4 & $\begin{array}{l}\text { Noltea C., Agrawal A., Silviusb } \\
\text { K.M., Soares-Filho B. }\end{array}$ & $\begin{array}{l}\text { Governance regime and location } \\
\text { influence avoided deforestation } \\
\text { success of protected areas in the } \\
\text { Brazilian Amazon }\end{array}$ & 2013 & PNAS \\
\hline 5 & $\begin{array}{l}\text { Börner J., Kis-Katos K., } \\
\text { Hargrave J., König K. }\end{array}$ & $\begin{array}{l}\text { Post-crackdown effectiveness of } \\
\text { field-based forest conservation law } \\
\text { enforcement in the Brazilian Amazon }\end{array}$ & 2015 & Plos One \\
\hline 6 & $\begin{array}{l}\text { Cisneros E., Zhou S.L., Börner } \\
\text { J. }\end{array}$ & $\begin{array}{l}\text { Naming and shaming for } \\
\text { conservation: evidence from the } \\
\text { Brazilian Amazon }\end{array}$ & 2015 & Plos One \\
\hline
\end{tabular}

Source: Own table

With respect to three types of protected areas (Policies 1-3), Nolte et al. 2013 find that all types of protected areas (strictly protected areas, sustainable use areas, and indigenous territories) help reduce deforestation in the Brazilian Amazon. Nolte et al. 2013 use matching techniques to create an artificial counterfactual for their analysis. In terms of mechanisms designed to reduce deforestation, Nolte et al. (2013, p. 4) examine the government agencies' ability to enforce conservation regulations and find that "all types of protected areas have contributed to avoiding deforestation in the Brazilian Amazon regardless of their specific conservation objectives." In the same vein, Soares-Filho et al. 2010 and Nelson and Chomitz 2011 also find that protected areas form an effective buffer against deforestation comparing areas inside with counterfactual areas outside protected areas. According to the Hargrave and Kis-Katos (2013, 
p. 483) model that assesses policies curbing deforestation in 663 municipalities between 2002 and 2009, "changes in the size of both protected and indigenous areas are negatively related to changes in deforestation." Thus, this paper also describes protected areas as an effective policy to reduce deforestation.

With respect to the blacklisting of municipalities (Policy 4), Cisneros et al. (2015) find that blacklisting municipalities with very high deforestation rates contributed to curbing deforestation. Cisneros et al. (2015, p. 13) use matching techniques and double difference regressions with panel data to show that "the average effect of blacklisting on deforestation in blacklisted districts ranges between roughly $13-36 \%$ considering standard errors." Cisneros et al. (2015) describe the policy mechanisms leading to reduced deforestation in blacklisted districts as reputational risk and increased external support (from NGOs) or pressure (from IBAMA). Similarly, Assunção et al. (2014, p. 10) find that the "mechanism through which the [blacklisting] policy had an effect [on] deforestation was the increase of monitoring intensity and quality." Thus, both papers suggest that enforcement is an important mechanism with respect to blacklisting and the public disclosure policy.

With respect to field-based forest law enforcement actions (Policy 5), Assunção et al. (2013, p. 22) find that "increased presence of police force in the Amazon accounts for the preservation of 59,500 square kilometers of forest area from 2007 through 2011.” Börner, Marinho, and Wunder 2015, p. 13) are less optimistic, finding that "inspections reduce deforestation by $14 \%$ on average." According to Börner, Marinho, and Wunder (2015), inspections reduced deforestation in only two out of six states. The delivery mechanism for this policy is fieldbased forest law enforcement missions. These missions seize or destroy production goods, tools, and materials, impose embargoes or fines on offenders, and arrest offenders.

In the next section, I will critically review the selected papers and assess their empirical strategy, paying special attention to how methodological choices affect results. I will follow the approach used by Samii et al. (2014).

\subsection{Potential Risks of Bias in Selected PaPers}

Samii et al. (2014) used six criteria to assess risk of bias in articles selected through their systematic review that covers PES. These criteria are: (1) avoid selection bias, (2) avoid confounding bias, (3) avoid motivation bias, (4) account for potential bias due to spillovers, (5) avoid selective outcome reporting and analysis fishing, and (6) use appropriate statistical 
inference (Samii et al. 2014). I will use these criteria to review my six selected papers and to avoid accepting empirical results about policy effects at face value. This critical discussion of the papers will also pay special attention to how methodological choices affect results.

Soares-Filho et al. (2010) use PRODES wall-to-wall deforestation data from 1997-2001 and focus on protected areas. They use adjacent internal and external 10-kilometer buffer zones as comparison groups to assess whether the protected areas were effective in reducing deforestation. This approach has the risk of selection bias given that areas inside a protected area tend to be more remote compared with areas outside the protected areas. To avoid (1) selection bias, Soares-Filho et al. calculate an odds ratio of deforestation. They ensure that areas outside and inside the protected areas have similar characteristics based on known drivers of deforestation, such as distances to rivers or roads and thus avoided selection bias.

Soares-Filho et al. (2010) also avoid (2) confounding bias by controlling for key confounder variables, such as the opening or paving of a road, more fertile soil, and low slopes, etc. By using quantitative data on annual deforestation from PRODES, as well as the FUNAI and Instituto Socioambiental websites on protected area boundaries, the paper also avoids (3) motivation bias from measurement strategies, meaning that the data was not self-reported.

The paper addresses (4) spill-over bias by explicitly testing for whether any spatial dependence existed between regions where protected areas expanded and regions where deforestation rates increased (Soares-Filho et al. 2010). In addition, by using wall-to-wall deforestation data and an odds ratio of deforestation to assess the local effect of protected areas on deforestation the paper avoided (5) selective outcome reporting and analysis fishing.

Lastly, and as shown in Table 28, Column 4, the paper reports on standard errors, avoiding any biases due to (6) inadequate statistical inference.

Nolte et al. (2013) focus on different types of protected areas and their effect on forest preservation. The paper avoids five of the six biases in its published version, as explained below. I was able to clarify (6) statistical inference bias by corresponding with the author directly.

Nolte et al. (2013) reduce (1) selection bias by creating artificial control groups of forest parcels for each protected area using matching techniques with replacement. They consider all protected areas established in or before 2005 using criteria such as at least 50 percent average tree cover in 2000 , located at least 60 percent within the humid tropical forest biome, etc. 
The paper effectively accounts for (2) confounding bias by controlling for elevation, slope, probability of flooding, baseline forest cover, distance to forest edge, travel time to major cities, and state. These are variables that according to the literature are associated with deforestation. The paper avoids (3) motivation bias from measurement strategies by using global databases, as well as official data from Brazil's Ministry of the Environment. The paper projects data on boundaries, deforestation, and vegetation from a total of five databases and extracted all humid tropical forest parcels with more than 25 percent average forest cover (VCF).

Nolte et al. (2013) address the (4) spill-over bias by excluding all unprotected forest parcels situated within 10-kilometer buffers around any protected area from the pool of potential controls. In light of Soares-Filho et al. (2010), Nolte et al. (2013) could also have tested their results in terms of similar landscape features.

Nolte et al. (2013) apparently also avoid (5) selective outcome reporting and analysis fishing. The corresponding author shared the dataset with me and I was able to verify the analysis using his data.

Finally, as to (6) statistical inference bias, the paper does not report standard errors. I therefore corresponded directly with the author and received his dataset, which allowed me to calculate the standard error myself.

Pfaff et al. (2015), as in the papers by Soares-Filho et al. (2010) and Nolte et al. (2013), focus on the effectiveness of protected areas at preserving forests. The paper avoids all six biases identified by Samii et al. (2014).

The authors reduce (1) selection bias by correcting for the tendency of protected areas to be in remote areas with low deforestation pressure. They also split their samples according to levels of pressure to show that conservation could be targeted with an explicit goal of increasing impacts of protected areas (Pfaff et al. 2015). Using propensity score matching as their empirical strategy, they carefully control for any differences is due to siting.

The authors avoid (2) confounding bias by controlling for other variables that could affect deforestation outcomes, such as "shifts in forest code, rise in enforcement, creation of a federal blacklist and local reactions" (Pfaff et al. 2015, p. 2). They also control for factors that affect the profitability of deforestation, distance to the nearest road, distances to the nearest city, 
distance to the forest's edge. In terms of biophysical conditions, the authors control for soil quality, rainfall, vegetation type, and slope.

In addition, the authors guard against (3) motivation bias from measurement strategies. They use deforestation data from PRODES, but do not provide a source of their protected area data, although they mention the number and type of protected areas. However, given that the numbers match analysis in other chapters in this dissertation, I trust that the authors took their protected area boundaries from one of the existing trusted databases. In addition, they include only eight of the nine states in the Legal Amazon, without explicitly stating why.

The authors address potential (4) spill-over bias by dropping controls nearby (20 kilometers) for the case that protected areas had spill-over effects in the vicinity. Compared with Nolte et al. (2013), who used a 10-kilometer buffer zone for potential spill-over effects, 20 kilometers seems to be safer. In addition, as in the case of Soares-Filho et al. (2010), they test for differences in landscape features and other confounding factors (see above under confounding bias).

Here again (5) selective outcome reporting and analysis fishing has been avoided. The authors use propensity score matching, or the probability of a pixel being protected, to identify comparison groups. They call their approach an "apples to apples" comparison by which they compared the land under protection not to all unprotected land but only to the most similar unprotected subset. Thereby, they estimate the true impact as a difference between "current forest and what would have happened in a protected area without the protection" (Pfaff et al. 2015, p. 4). Thus, they use rigorous impact evaluation methods to assess the impact of protected areas on forest preservation, likely avoiding elective outcome reporting.

Lastly, the authors also avoid (6) statistical inference by calculating standard errors that I report in Table 28, Column 4.

Hargrave and Kis-Katos (2012) focus on the effect of IBAMA forest police activities on deforestation. The paper does not use a counterfactual analysis but employs a panel dataset and an empirical strategy that addresses five of the six biases listed by Samii et al. (2014).

Hargrave et al. (2012) reduce (1) selection bias by adjusting their analysis for differences in baseline measurements using instrumental variables (IV) in a dynamic panel framework to account for endogeneity between their policy variable (IBAMA activities) and economic 
factors (meet, soybean, and wood prices), each of which could influence the observed decline in deforestation.

Hargrave et al. (2012) control for (2) confounding bias by including time invariant differences between municipalities (such as climate, remoteness, economic structure, etc.) in their panel model. They address (3) motivation bias from measurement strategies by relying on official data sources. In particular, they use PRODES deforestation data from the Brazilian Space Research Institute, agriculture-related variables from the Brazilian Statistical Office (IBGE 2011), data on environmental fines from IBAMA, and protected area boundaries from DAP/MMA (Protected Areas Directory of the Brazilian Environmental Ministry). They obtained data on the size of the official subsidized agricultural credit from the Rural Credit Annual Reports of the Brazilian Central Bank, and weather-related data from NASA.

Hargrave et al. (2012) address potential (4) spill-over bias by estimating "spatial panel models that control for spatial spillovers of deforestation and of environmental police presence" (Hargrave et al. 2012, p. 474). They find spatial spill-over effects for both deforestation and IBAMA forest police actions.

The authors avoid (5) selective outcome reporting and analysis fishing by employing yearly panel data models (from 2002 to 2009) for 663 municipalities in the region and first difference and fixed effects analysis. Hargrave et al. (2012) base their analysis on municipalities in the Brazilian Amazon, but exclude areas with little forest from their sample, such as areas with tropical savanna in the Cerrado and areas that have less than 10 percent forest cover. However, these exclusions do not negatively affect the analysis, as shown by robustness checks, but improve the fit of the model.

Börner et al. (2015) focus on IBAMA's field-based enforcement missions. The paper addresses all six of the biases listed by Samii et al. (2014).

Börner et al. (2015) reduce (1) selection bias by matching grid cells that have been visited by the IBAMA forest police with similar areas that have not been visited by IBAMA staff, based on observable characteristics, such as historical deforestation, travel distance, as well as other known variables that affect deforestation. Matching accounts for the fact that IBAMA inspections are not randomly allocated in space, but are potentially endogenous to deforestation, meaning that in locations with high deforestation, IBAMA missions are more 
likely. By matching comparable grid cells with and without IBAMA missions, the study accounts for this bias.

The paper also controls for (2) confounding bias by controlling for variables that also influence deforestation, such as distance to urban centers, precipitation, demographic characteristics, and land cover types, among others, in addition to using a matching approach.

Furthermore, Börner et al. (2015) address (3) motivation bias from measurement strategies. They rely on official data sources from IBAMA and PRODES for their analysis. In addition, the paper avoids (4) spill-over bias. As mentioned before, spatial auto-correlation plays an important role in the context of environmental policies as measured by a spatial matching approach. In the case of this paper, not accounting for spill-over effects of IBAMA enforcement missions on neighboring locations could potentially underreport the effect. Similarly, the characteristics of one location, especially deforestation in one area could be correlated with a neighboring area. The paper effectively addresses both biases by reporting results first including neighboring areas, and second, excluding neighboring areas.

Börner et al. (2015) also avoid (5) selective outcome reporting and analysis fishing, by making explicit which areas they excluded from their analysis and why. As in the case of Hargrave et al. (2012), they exclude areas with low forest cover because characteristics in these areas are different from forested areas.

Cisneros et al. (2015) cover the policy on public disclosure. They call the public disclosure process "blacklisting." The paper avoids all six biases described by Samii et al. (2014).

Cisneros et al. (2015) effectively reduce (1) selection bias by matching blacklisted municipalities with municipalities that have not been blacklisted based on pre-blacklist characteristics, in order to identify what would have happened in the absence of blacklisting. Given that the control group has likely lower pre-treatment levels of deforestation, the paper uses double differences in their empirical strategy. Thus, they separate out the effect even though treatment and control group may have had different levels.

The authors also control for (2) confounding bias by controlling for covariates that could affect deforestation levels, such as baseline forest cover, agricultural intensification, and average land values, GDP per capita, timber, and soy prices, among others. In addition, they avoid (3) motivation bias from measurement strategies by relying on official data from the Brazilian 
Legal Amazon district database from the Brazilian Institute for Geography and Statistics (IBGE) and INPE-PRODES, as well as data on additions and removals to the blacklist from Decree 6.321/2007 and several provisions (Cisneros et al. 2015).

Furthermore, Cisneros et al. (2015) avoid potential (4) spill-over bias such as leakage or deterrence. Leakage would occur if deforestation took place in a neighboring municipality instead of the blacklisted one leading to more deforestation. On the other hand, people in neighboring provinces could stop cutting down trees because they see the consequences in the neighboring municipality, thus increasing conservation. They test for spill-over effects of backlisted to non-blacklisted municipalities and do not find spillovers.

Cisneros et al. (2015) discuss potential biases in their analysis and thereby avoid (5) selective outcome reporting and analysis fishing.

In the next section, I will discuss methodological underpinnings of how to make different effect sizes comparable.

\subsection{HoW To MAKe Different EFFect Sizes CoMparable}

The six selected papers have different sample sizes, different outcomes, different estimation methods, and different scales. Therefore, it was important to make results from the different papers comparable.

To establish comparability, I followed an approach taken in the systematic review literature that compares the effects of impact evaluations that used quasi-experimental designs and some form of matching. This type of evaluation design allows researchers to determine the causal links between the environmental policies and their effects on deforestation (in my case). Generally, impact evaluations using quasi-experimental designs are great instruments to determine the internal validity of a program. Internal validity "is the approximate truth about inferences regarding cause-effect or causal relationships. ${ }^{~} 85$ A common critique about impact evaluations using quasi-experimental designs is that results of a study cannot be generalized to other situations, location, and to other people, ${ }^{86}$ meaning that their external validity is low. A systematic review is designed to overcome the shortcoming of low external validity of findings

\footnotetext{
${ }^{85}$ Retrieved on December 28, 2017, from https://www.socialresearchmethods.net/kb/intval.php.

${ }^{86}$ Retrieved on December 28, 2017, from: https://en.wikipedia.org/wiki/External_validity.
} 
by making the effect sizes of different studies for the same type of impacts comparable (Rossi et al. 2007, Waddington et al. 2012, White and Waddington 2012). However, a problem persists in that a systematic review can only rely on already published studies that are comparable, leaving issues that cannot be easily measured, or captured in a quasi-experimental design excluded from the review. Some of the advantages of using a quasi-experimental design with comparison groups is that this type of study design addresses spill-over effects and leakage (Samii et al. 2014).

Puyravaud (2003) developed a methodology for standardizing the calculation of the annual rate of deforestation. His method is based on the compound interest law, generally used in finance to determine the accrued interest that is calculated by adding the interest to the principal, which is called compounding. ${ }^{87}$ Puyravaud developed a formula for calculating the annual rate of forest cover change under the compound interest law.

Following Puyravaud (2003), Samii et al. 2014 build on the annual rate of forest cover change under the compound interest law using the following formula by providing an example.

$$
\mathrm{r}=\ln (\mathrm{C} / \mathrm{C} 0) /(\mathrm{t} 2-\mathrm{t} 1)
$$

Referring to Puyravaud (2003), Samii et al. (2014) describe his formula as "C is the amount of forest cover at the time of follow-up, $\mathrm{C} 0$ is forest cover at baseline, $\mathrm{r}$ is the continuous rate of change per unit of time, and $\mathrm{t} 2-\mathrm{t} 1$ is the amount of time elapsed between periods $\mathrm{t} 1$ and $\mathrm{t} 2$ " (Samii et al. 2014, p. 78). The formula can capture forest cover growth and deforestation. Following Samii et al. (2014, p. 78) "a program that has the effect of sustaining a 0.01 increase in the annual rate of forest cover change (or, a 0.01 decrease in the deforestation rate) would induce on the order of a 10 percent increase in the extent of forest cover after ten years and 20 percent increase in the extent of forest cover after 20 years, as compared to the counterfactual of no program." This shows that even a small annual rate of change can lead to a somewhat sizable difference in forest cover over time, especially if the forest area is large.

I rely on Samii et al. (2014) also referred to in Börner et al. (2016) for making my six selected papers comparable using the following formulas.

For the effect size, see equation 4, and for the standard error, see equation 5.

\footnotetext{
${ }^{87}$ Retrieved on December 28, 2017, from: https://definitions.uslegal.com/c/compound-interest/.
} 


$$
\delta=\left[\left(\frac{\mathrm{FT}_{\mathrm{T}}}{F T_{\mathrm{T}}-\Delta}\right) /\left(\mathrm{t}_{1}-\mathrm{t}_{2}\right)\right] 100
$$

and

$$
\operatorname{se}\left(\delta=\left[\operatorname{se}(\Delta) /\left\{\left(\mathrm{FC}_{\mathrm{r}}-\Delta\right)\left(t_{2}-t_{1}\right)\right\}\right] 100\right.
$$

Equation 4 captures the effect size of average annual change in forest cover for the different environmental policies. Thus, I estimate the average effect (effect size) of a policy on forest cover change per year by dividing mean forest cover in the treatment group by mean forest cover in the treatment group minus the change and adjusting for the years the policy has been in effect. Equation 5 captures the standard error for mean forest cover in treated observation units. The delta $\Delta$ captures the effect on forest cover as estimated in the different papers, and $\mathrm{t}_{2}$ - $t_{1}$ captures the time elapsed between the end and the beginning of the treatment period. Results are presented and discussed below.

\subsection{DATA AND SUMMARY STATISTICS-How NON-STANDARDIZED EFFECT SizES COMPARE}

Table 27 provides an overview of the different policies, their effect sizes, and the evaluation period. All six authors of the selected papers focus on the Brazilian Amazon. They use measure of forest cover change based on remote sensing technologies. Four authors analyze different forms of protected areas, and one each focuses on enforcement and public disclosure.

In terms of their methodological focus, and as discussed in more detail above, Pfaff et al. (2015) Börner et al. (2015), Cisneros et al. (2015), and Nolte et al. (2013) used a matching comparison, Soares-Filho et al. (2010) use pairwise comparison for their analysis, and Hargrave and KisKatos (2013) use a panel model. All six authors use some form of deforestation measure as their outcome variable.

In the following paragraph, I list the specific outcome variables that the four authors use when they analyze protected areas. Pfaff et al. (2015) used the proportion deforested between 2000 2005 in protected areas as their outcome measure. Soares-Filho et al. (2010) used an odds ratio of deforestation for the years 1997-2008 as their outcome measure for different types of protected areas. They describe their method as "adjusted odds ratio of deforestation" (Soares-Filho et al. 2010, p. 10822). The method "compensates for differences in probability of deforestation in areas used for pairwise comparison without requiring matching samples" (Soares-Filho et al. 2010, p. 10822). Hargrave and Kis-Katos (2013) use "change in deforestation" as their outcome measure 
for the years 2002-2009 for protected areas. Nolte et al. (2013) used "percent change" in PRODES deforestation between 2000 and 2005 to estimate the effectiveness of different types for protected areas at reducing deforestation.

Börner et al. (2015) analyze enforcement policies using "change in forest loss" as the outcome variable for the years 2010 to 2011. Lastly, Cisneros et al. (2015) analyze public disclosure policies or blacklisting of municipalities using a similar outcome variable as Börner et al. 2015) of "change in forest loss" for the years 2008-2012.

Table 27. Papers selected for the systematic review with their methodological focus, main findings, and effect size

\begin{tabular}{|c|c|c|c|c|c|}
\hline Authors & Region & $\begin{array}{l}\text { Environmental } \\
\text { policy }\end{array}$ & $\begin{array}{l}\text { Methodological } \\
\text { focus }\end{array}$ & Main finding & $\begin{array}{l}\text { Effect size } \\
\text { (Cohen's d) }\end{array}$ \\
\hline $\begin{array}{l}\text { Pfaff et } \\
\text { al. } \\
(2015)\end{array}$ & $\begin{array}{l}\text { Brazilian } \\
\text { Amazon }\end{array}$ & $\begin{array}{l}\text { Protected } \\
\text { Areas }\end{array}$ & Matching & $\begin{array}{l}0.9-1.23 \% \text { reduction of } \\
\text { forest loss in protected } \\
\text { areas }(2000-2005)\end{array}$ & $\begin{array}{l}\text { Outcome } \\
\text { variable } \\
(\mathrm{OV})^{*} \text { : } \\
\text { Proportion } \\
\text { deforested } \\
\text { ES: }-0.096\end{array}$ \\
\hline $\begin{array}{l}\text { Soares- } \\
\text { Filho et } \\
\text { al. } \\
(2010)\end{array}$ & $\begin{array}{l}\text { Brazilian } \\
\text { Amazon }\end{array}$ & $\begin{array}{l}\text { Protected } \\
\text { Areas }\end{array}$ & $\begin{array}{l}\text { Pairwise } \\
\text { comparison }\end{array}$ & $\begin{array}{l}37 \% \text { of the decline in } \\
\text { deforestation was caused } \\
\text { by protected areas } \\
(1997-2008)\end{array}$ & $\begin{array}{l}\text { OV: Odds } \\
\text { ratio of } \\
\text { deforestation } \\
\text { ES: } 0.0078\end{array}$ \\
\hline $\begin{array}{l}\text { Nolte et } \\
\text { al. } \\
(2013)\end{array}$ & $\begin{array}{l}\text { Brazilian } \\
\text { Amazon }\end{array}$ & $\begin{array}{l}\text { Protected } \\
\text { Areas }\end{array}$ & $\begin{array}{l}\text { Counterfactual } \\
\text { design using } \\
\text { artificial controls }\end{array}$ & $\begin{array}{l}\text { Strictly protected areas } \\
\text { consistently avoided } \\
\text { more deforestation than } \\
\text { sustainable use areas. } \\
\text { Indigenous lands were } \\
\text { particularly effective at } \\
\text { avoiding deforestation in } \\
\text { locations with high } \\
\text { deforestation pressure }\end{array}$ & $\begin{array}{l}\text { OV: Percent } \\
\text { change in } \\
\text { PRODES } \\
\text { deforestation } \\
(2000-2005) \\
\text { ES: } 0.0030 \\
\text { for strictly } \\
\text { protected } \\
\text { areas }\end{array}$ \\
\hline $\begin{array}{l}\text { Hargrave } \\
\text { (2013) }\end{array}$ & $\begin{array}{l}\text { Brazilian } \\
\text { Amazon }\end{array}$ & Enforcement & Panel model & $\begin{array}{l}\text { A one percent increase in } \\
\text { fining intensity resulted in } \\
\text { a roughly } 0.2 \% \text { decrease } \\
\text { in deforestation }\end{array}$ & $\begin{array}{l}\text { OV: Change } \\
\text { in } \\
\text { deforestation } \\
\text { ES: } 12.68 \\
(2002-2009)\end{array}$ \\
\hline
\end{tabular}




\begin{tabular}{|c|c|c|c|c|c|}
\hline Authors & Region & $\begin{array}{l}\text { Environmental } \\
\text { policy }\end{array}$ & $\begin{array}{l}\text { Methodological } \\
\text { focus }\end{array}$ & Main finding & $\begin{array}{l}\text { Effect size } \\
\text { (Cohen's d) }\end{array}$ \\
\hline $\begin{array}{l}\text { Börner et } \\
\text { al. } \\
\text { (2015) }\end{array}$ & $\begin{array}{l}\text { Brazilian } \\
\text { Amazon }\end{array}$ & Enforcement & $\begin{array}{l}\text { Pairwise } \\
\text { comparison }\end{array}$ & $\begin{array}{l}14 \% \text { reduction of forest } \\
\text { loss per year }(2010- \\
2011)\end{array}$ & $\begin{array}{l}\text { OV: Change } \\
\text { in forest loss } \\
\text { ES: }-0.063\end{array}$ \\
\hline $\begin{array}{l}\text { Cisneros } \\
\text { et al. } \\
(2015)\end{array}$ & $\begin{array}{l}\text { Brazilian } \\
\text { Amazon }\end{array}$ & $\begin{array}{l}\text { Public } \\
\text { disclosure }\end{array}$ & $\begin{array}{l}\text { Pairwise } \\
\text { comparison }\end{array}$ & $\begin{array}{l}\text { 13-36\% reduction of } \\
\text { forest loss; 2008-2012 }\end{array}$ & $\begin{array}{l}\text { OV: Change } \\
\text { in forest loss } \\
\text { ES: }-3.79\end{array}$ \\
\hline
\end{tabular}

Note: Effect size (ES) is defined as the estimated effect divided by the standard deviation of the * outcome variable $(\mathrm{OV})$ in the control group.

Source: Own table

I also included the standard error in my analysis by either identifying it in the paper or corresponding directly with the author and asking him to share the information on standard errors.

The main findings in the different papers can be summarized as follows: Pfaff et al. (2015) found a $0.9-1.23$ percent reduction of forest loss in protected areas for the years 2000-2005. Soares-Filho et al. (2010) found that protected areas caused a 37 percent decline in deforestation between 1997 and 2008. Furthermore, Hargrave and Kis-Katos (2013) found that "a one percent increase in fining intensity resulted in a roughly $0.2 \%$ decrease in deforestation" over the same period. Comparing the effectiveness of different types of protected areas, Nolte et al. (2013) found that strictly protected areas consistently avoided more deforestation than sustainable use areas. Indigenous lands were particularly effective at avoiding deforestation in locations with high deforestation pressure.

Börner et al. (2015) found that enforcement policies reduced forest loss by 14 percent per year in 2010 and 2011. Whereas Cisneros et al. (2015) found that public disclosure (or blacklisting municipalities) reduced forest loss by between 13 and 36 percent during 2008-2012. Hargrave and Kis-Katos (2013) found that law enforcement resulted in a 2.13 percent reduction in deforestation during 2002-2009.

Findings from the six papers show some diversity in results measurement. They range from a low of 0.1 percent over a seven-year period (2002-2009, Hargrave and Kis-Katos 2013) to a 37 percent decline in deforestation between 1997 and 2008 (Soares-Filho et al. 2010). Using the formulas presented earlier, I will now present the results of the adjusted effect sizes made comparable for this review. 


\subsection{RESULTS-COMPARISON OF STANDARDIZED EFFECT SIZES}

I used the two formulas explained in section 4.5 to make the effect sizes for the selected papers comparable.

I found that in terms of orders of magnitude the different papers estimated a comparable effect size for the five different environmental policies in Brazil. Effect sizes for environmental policies in the Brazilian Amazon are modest. Table 28 shows the effect size and standard error for the five environmental policies. Effect sizes range from a minimum of 0.05 percent to 1.04 percent. These effect sizes are in line with other papers that generally find small effect sizes for forest conservation program. For example, Samii et al. (2014, p. 12) find similar results when assessing the effect of PES on deforestation and forest cover outcomes. Börner et al. (2016, p. 6) come to similar results when they state: "small effects are thus not necessarily a unique feature of PES programs, but instead seem to be a more general characteristic of tropical forest conservation programs." A small effect size in tropical forest conservation programs more generally also confirms our own findings presented in chapter three of this dissertation, where we found a null effect between demarcated and not yet demarcated indigenous territories.

Table 28. Effect size and standard error for making the results from selected papers comparable

\begin{tabular}{|l|l|r|r|}
\hline Policy type & \multicolumn{1}{|c|}{ Corresponding author } & $\begin{array}{c}\text { Effect size } \\
{[\%]}\end{array}$ & $\begin{array}{c}\text { Standard } \\
\text { error }\end{array}$ \\
\hline Protected Areas & Soares-Filho (2010) & 0.7812 & 0.0849 \\
\hline Strict protection before 2000 & Nolte (2013) & 0.4074 & 0.2117 \\
\hline Sustainable use before 2000 & Nolte (2013) & 0.3097 & 0.3723 \\
\hline Indigenous lands before 2000 & Nolte (2013) & 1.0358 & 0.2768 \\
\hline Strict protection before 2005 & Nolte (2013) & 0.3810 & 0.2106 \\
\hline Sustainable use before 2005 & Nolte (2013) & 0.0528 & 0.1031 \\
\hline Indigenous lands before 2005 & Nolte (2013) & 0.2668 & 0.1399 \\
\hline Protected areas & Pfaff (2015) & 0.5853 & 0.2546 \\
\hline Law Enforcement & Hargrave (2012) & 0.5766 & 0.2709 \\
\hline Law enforcement & Börner (2015) & 0.1315 & 0.0492 \\
\hline Public disclosure & Cisneros (2015) & 0.2928 & 0.1529 \\
\hline Souce: Own table & & & \\
\hline
\end{tabular}

Source: Own table 
In my selected papers, effect estimates for protected areas range between a 0.59 percent reduction in the deforestation rate (Pfaff et al. 2015) and 0.78 percent (Soares-Filho et al. 2010). According to Nolte et al. (2013), strictly protected areas had an effect of 0.41 percent and 0.38 percent, depending on whether they were established before 2000 or more recently. The effect for sustainable use areas ranged between 0.31 percent to 0.05 percent, and the effect for indigenous territories was largest and ranged between 1.04 percent and 0.27 percent, depending on the period and whether they were in a high-pressure zone, according to Nolte et al. (2013), see Table 28.

Börner et al. (2016) find an average annual effect on deforestation of 0.13 percent as an effect of the IBAMA law enforcement policy, while Hargrave and Kis-Katos 2013 find a 0.58 percent effect for IBAMA enforcement actions using a panel model. Finally, Cisneros et al. (2015) find an effect of 0.29 percent for public disclosure policies.

To compare results: indigenous lands seem to have the largest effect on deforestation followed by protected areas. However, these policies have been under implementation for a longer period and given the long duration environmental policies require to show results, these findings are not surprising.

Even though effects seem relatively small on average, I need to put them in context. As Samii et al. (2014) interpret, an environmental policy that sustains a 0.01 reduction in the annual rate of deforestation - a finding in Table 28, as well as in chapter three-would lead to a " 10 percent increase in the extent of forest cover after ten years and 20 percent increase in the extent of forest cover after twenty years, as compared to the counterfactual of no program" (Samii et al. 2014, p. 78). Environmental protection programs take time to show an effect and most papers consider short time periods of between 5 and 10 years. For the context of this paper, however, we need to keep in mind that Samii et al. (2004) considers regrowth, while I look at the decline in deforestation only.

Figure 21 shows the different effect sizes and standard errors for the five policies based on the papers analyzed for this review. It is a visualization of Table 28. The small black diamonds represent the effect size of the environmental policies listed to the left and the horizontal lines represent the standard errors. The average effect size for the different policies was 0.44 percent. 
Figure 21. Systematic review: Comparing effect sizes in the literature for five environmental policies in the Brazilian Amazon

Public Disclosure
Law Enforcement
Law Enforcement
Indigenous lands before 2005
Sustainable use before 2005
Strict protection before 2005
Indigenous lands before 2000
Sustainable use before 2000
Strict protection before 2000
Protected Areas
Protected Areas
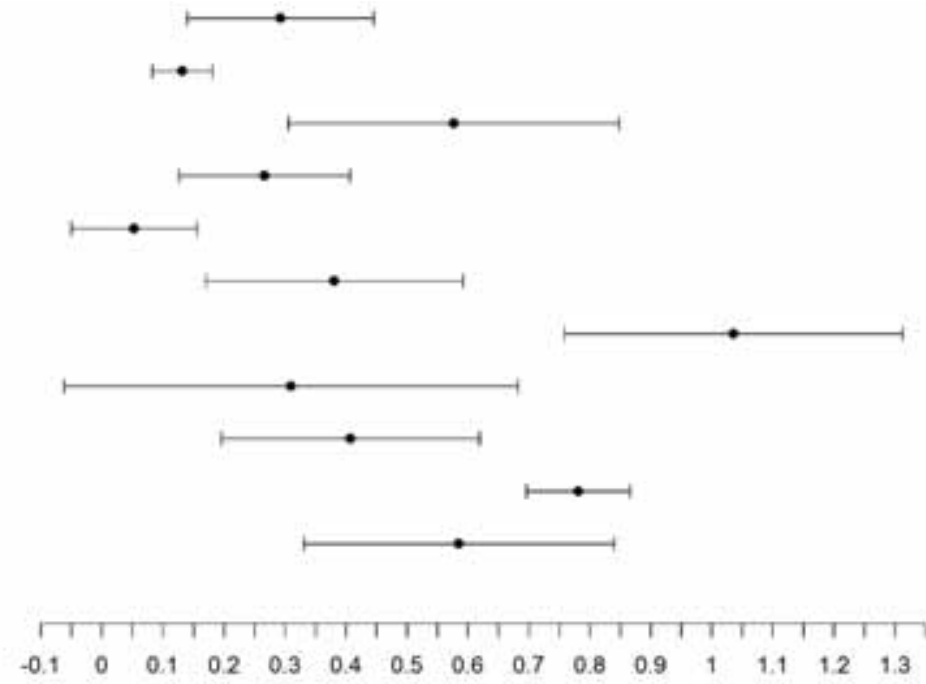

Effect on average annual change in forest cover [\%]

Source: Own calculations based on Börner et al. 2016, and Samii et al. 2014, and Puyravaud (2003).

If I then compare the effectiveness of the different policies, I find that indigenous territories implemented before 2000 were the most effective policy, as were protected areas more generally. Even though the average effect size is relatively small, with 0.44 percent, Figure 21 shows substantial variation with small effects ranging from 0.04 to 0.13 percent, medium effects ranging from 0.27 to 0.59 percent, and large effects ranging from 0.78 to 1.04 percent. The bulk of the effect sizes, seven in number, range in the middle with two outliers lower and two higher. In general, therefore, the different estimates are similar in magnitude and thus confirm a relatively small annual effect.

The results presented in Figure 21 are plausible. The variation in the standard errors indicates that some of the results were more precisely estimated than others. This corresponds to the findings of the individual papers that I analyzed for this review. Different papers covering the same policy show slightly different results. This can be expected given that the modeling results depend on the local context. Variation in the estimates, although small, also reflect the challenges associated with modeling the effect of environmental policies on forest preservation more generally. 
As discussed in chapter three, and at the beginning of this chapter, studies that compare the effects of tropical forest conservation programs tend to encounter remote location bias (see also Börner et al. 2015). This means that protected areas may be situated in locations that are not yet threatened by deforestation but that may be threatened at a later stage, once the deforestation activity moves closer to the protected area. Nolte et al. (2013), for example, tested for high-pressure zones and found that indigenous territories located close to an area of high deforestation pressure were preserving forests more effectively than other protected areas, or indigenous territories in other zones with lower forest pressure.

Another bias was mentioned by Hargrave and Kis-Katos (2013). In their model, they noticed a high correlation between those municipalities that encountered high IBAMA fines and high deforestation. This is because IBAMA becomes active in those municipalities with the highest deforestation activity. Due to the correlation the effect estimate is smaller than could have been expected otherwise. Börner et al. (2015) control for this bias when using matching techniques.

\subsection{DisCuSSION AND CONCLuSIONS-EFFECT Sizes FOR Tropical Forest Conservation Programs Tend to be Relatively SMall on AVERage}

This section highlighted two important points. First it provided a context for my earlier estimates of the forest preservation effects of demarcation of indigenous territories. The results of this analysis show that my estimates are in the range of what can be expected from a tropical forest protection program. Second, this chapter compared the findings of six papers on different environmental policies in Brazil demonstrating that the average annual magnitude of the forest preservation effect is relatively small, ranging from an average annual 0.05 percent decrease in deforestation to up to 1.04 percent, with an average of 0.44 percent. This means that even though forest conservation policies are vital for forest protection, the preservation of biodiversity, and the reduction of greenhouse gas emissions, the annual effect seems modest.

In addition, at this time, few published studies use counterfactual evaluation designs and remote sensing deforestation estimates (Börner et al. 2015) that would allow analysis based on a larger number of selected papers. Furthermore, estimating the effect of tropical forest conservation programs seems difficult to measure over a period of a decade or less. However, as the statistical methods and remote sensing techniques become more and more sophisticated there is hope that better approaches will be developed that will be able to capture conservation effects. 
Lastly, it is difficult to determine to what extent the effects measured in the six papers capture the policy variables or to what extent the implementation context plays an important role, something that is not being captured by the models. More research is needed requiring a mixed methods approach to better capture the effect of an environmental policy and its implementation context.

The outliers in effect size raise some interesting questions about how the relatively wide range of some effect sizes can be explained. While some of the differences are due to different time periods and higher versus lower deforestation pressure, others can be explained by the difference in estimation methods of two different publications.

The policy on indigenous areas in the Nolte et al. (2013) paper seems to be especially effective in earlier years and when confronted with high deforestation pressure. Nolte et al. (2013) compares deforestation pressure inside indigenous territories with artificial controls for similar areas outside the protected area. They find a strong effect because of the location of indigenous territories in high pressure areas of deforestation.

The effect size for more recently legalized indigenous territories is much smaller ( 0.27 percent), because deforestation pressure declined between 2006 and 2010. An effect size of 1.04 percent for the the years 2000 to 2006 shows that indigenous territories tend to form a buffer against deforestation when the pressure is high. This resonates with chapter three, which shows no effect between demarcated and non-demarcated indigenous territories, because they are not yet threatened by deforestation. In addition, the cover page of this book provides a picture of several indigenous territoritories that form a buffer against deforestation.

According to Nolte et al. (2013), the same pattern applies to sustainable use areas, where the effect size is varies from a medium effect size of 0.31 percent for the earlier period to a small effect size of 0.05 percent for the the later years. Here again, deforestation pressure accounts for some of the difference.

Hargrave et al. (2012) and Börner et al. (2015) both analyzed the effectiveness of the IBAMA enforcement mission. When I compare the effect sizes in both papers, I find a medium effect size of 0.5766 percent for Hargrave et al. (2012) and a small effect size of 0.1315 percent for Börner et al. (2015). The difference in effect sizes is a result of the way the papers measured IBAMA enforcement missions. 
Hargrave et al. (2012, p. 474) use panel data from 2002 to 2009 for 663 municipalities and use different instrumental variables to account for endogeneity biases. Their finding that "a one percent increase in fining intensity resulted in a roughly $0.2 \%$ decrease in deforestation" is more optimistic than that of Börner et al. $(2015$, p. 1) who find that "inspections have been most effective in reducing large-scale deforestation in the states of Mato Grosso and Pará, where average conservation effects were 4.0 and 9.9 hectares per inspection, respectively."

The findings of Börner et al. (2015) are less optimistic for several reasons: (1) they use a matching approach, controlling for confounding bias, and (2) they examine enforcement in the years 2009 and 2010, and (3) they examine different states and large-scale versus small-scale deforestation. In their analysis, IBAMA fines are efficient in deterring large-scale deforestation in two states, but they are only an incentive mechanism for smaller-scale deforestation.

The six selected papers in this systematic review analyze the effects of different environmental policies by isolating the effects of one policy on deforestation. However, interlinkage or overlap can exist between the policy measures analyzed and how they impact results. For example, the IBAMA enforcement policy helps enforce compliance and protect the borders and integrity of the three different types of protected areas. The large effects observed in protected areas could therefore be influenced by the IBAMA enforcement policy as enabler.

The policy on public disclosure overlaps with the IBAMA enforcement policy and the three types of protected areas depend on the blacklisted municipalities. In blacklisted municipalities, the effect of IBAMA enforcement could be lower, because IBAMA which is responsible for implementing both policies may prioritize municipalities that are not blacklisted, thus leading to a potential overreporting of IBAMA effectiveness in this case.

In chapter five, I will examine the theoretical impact pathways of different environmental policy mechanisms in greater detail and discuss their overlaps on the ground. To do this, I will include variables for the five different policies discussed here in one model and add three additional ones for which I did not find papers that met my selection criteria in this chapter.

In this chapter, I answered the research question "How do environmental policies compare with each other in terms of their effect sizes?" I found that the general annual effect of reducing deforestation is modest. However, it was important to notice that the effect size of forest conservation policies was similar across the six papers and five different environmental policies analyzed. 
This chapter contributes to the literature in that it adjusted the effect sizes from six papers that use some form of matching in their design (except one paper that used a panel model) and establishes comparability of the effect sizes. By this means, I found a modest but comparable effect size for the different papers and environmental policies in the Brazilian Legal Amazon.

In chapter five, I use a panel model and variable for different environmental policies to find out what their marginal effect is on the reduction in deforestation. 



\section{ENVIRONMENTAL POLICIES AS DRIVERS OF FOREST CONSERVATION-AN ECONOMETRIC APPROACH}

\subsection{INTRODUCTION}

My quest into the extent to which environmental policies explain how annual deforestation in the Brazilian Amazon declined so fast culminates in this chapter. In chapter two, I explored evidence through case studies on four indigenous territories in the Brazilian state of Amazonas. In chapter three, I determined the effect of demarcation on forest preservation. In chapter four, I found a relatively small average effect size of environmental policies on forest preservation as determined by six papers. In chapter five, I want to answer the research question: "To what extent can environmental policies be associated with a decrease in deforestation in the Brazilian Amazon?" I use a geospatial panel dataset to answer this question. By measuring the marginal effect of eight different environmental policies on deforestation, I contribute to the existing literature. Determining the marginal effect of the overlapping policies on the ground will help me better understand the sudden decline in deforestation and the role that environmental policies may have played. Elias Cisneros contributed to this chapter as explained in detail in Table 2 at the beginning of this dissertation. I will use the pronoun "we" in this chapter to indicate that collaboration.

For about a decade, Brazil has demonstrated that the rate of deforestation in the Amazon can be reduced, bringing deforestation from a high of 27,772 square kilometers in 2004 to a low of 5,012 square kilometers in 2014. Since then, deforestation has continued to decrease, though it has increased during the last two years. While most scholars say that this decline in deforestation can be associated with economic factors, such as lower commodity prices for fuel, beef, soy, and timber (making the production of beef, soy, and timber less profitable), others attribute the decline in deforestation to individual policies that were introduced during the same period.

Using geospatial econometrics and quasi-experimental designs, recent studies have been able to associate the decline in deforestation with key environmental policies (Aguiar et al. 2007, Arima et al. 2014, Assunção and Rocha 2014, Börner et al. 2015, Cisneros et al. 2015, Gibbs et al. 2015). Multiple policies are operating at the same time with different intensities. It is 
therefore impossible to remove all the biases and claim causation. Therefore, I refrain from claiming causation and speak of correlation. I do not disentangle the effect in this chapter. However, I identify the marginal effect of these overlapping policies on the declining trend in deforestation, something that has not been accomplished before. Thus, this paper contributes to the literature by establishing the marginal share of each policy in explaining the decline. Knowing what marginal share of the overlapping policies can be associated with curbing deforestation will be important for Brazil's future, as well as for countries in Asia and Africa with large tropical forests.

Figure 4, at the beginning of this dissertation, illustrates the dramatic decline in area deforested in the Brazilian Amazon since 2004. The welcome decline in deforestation raises questions of whether environmental policies can be associated with that decrease. In other words, I want to know whether environmental policies can be associated with deforestation. The model will not estimate causation, but an association between the environmental policies and deforestation. Because of the overlap of the environmental policies on the ground, I am estimating a marginal effect.

In chapter four, I compared the effect size determined by individual authors of environmental policies on deforestation. This chapter compares the relative effect of eight environmental policies to reduce deforestation in the Brazilian Amazon between 2003 and 2012. The analysis uses a model that captures deforestation in the Brazilian Amazon. It includes a variable for each of the different policies in one model and determines the relative effect of each policy on deforestation using fixed effects and first difference estimates.

The policies to be examined are the following: (1) protected areas; (2) public disclosure or blacklisting of municipalities; (3) field-based forest law enforcement actions; (4) the expansion of the rural environmental registry system (CAR); (5) credit restrictions; and (6) the Soy Moratorium. Historically, the expansion of the protected area system was among the first policy strategies to protect forests, whereas most other policy instruments were only implemented after 2004 in conjunction with the Plan to Combat Deforestation in the Amazon (PPCDAM in its Portuguese acronym). In this section, I seek to improve the understanding of the contribution of each of these policy instruments to reducing Amazon forest loss.

The general impact pathway of the different policies starts from a degree or regulation, or in the case of the indigenous territories, from Brazil's 1988 Constitution. The regulations stipulate 
limiting access to forest resources in different ways (see mechanisms below) and enforcing compliance. This leads in turn to farmers complying with the Forest Code and refraining from cutting down trees.

The different policies use the following mechanisms to curb deforestation:

(1) Strictly protected areas need personnel, equipment, and a budget to monitor and enforce protected areas against intruders. Sustainable use areas and indigenous lands involve local people in monitoring the protected area, by providing them with incentives to make a living through sustainable use of forest products. The assumption in this case is that local and indigenous people living from the forest have a self-interest in preserving forest resources.

(2) Sustainable use areas involve local people in monitoring the protected area by providing them with the incentives to make a living through sustainable use of forest products. The assumption in this case is that local people living from the forest have a self-interest in preserving forest resources.

(3) Indigenous territories also involve local people in monitoring the protected area by providing them with incentives to make a living through sustainable use of forest products. The assumption in this case is that indigenous people living from the forest have a self-interest in preserving forest resources, something that indigenous communities tend to do as explained in chapter two.

(4) The environmental police (IBAMA) monitors deforestation on a bi-weekly basis and identifies offenders. It then conducts field-based enforcement missions that involve fines; embargoes; arrests; seizures and destruction of production goods, tools, and material, among others.

(5) The public disclosure policy picks communities based on their past high deforestation records and shames them into complying with the Forest Code by also attracting external NGO support to help foster compliance.

(6) Rural credit institutions restrict providing funding to those farmers that produce in compliance with the Forest Code.

(7) The Soy Moratorium limits demand from big retailers for soy crops grown on land deforested before 2006.

(8) The rural cadaster system (CAR), clarifies land rights and monitors and enforces compliance with Brazil's Forest Code. 
In the last decade, Brazil has introduced some of the environmental policies listed above to curb deforestation in the Amazon. By signing these policies into law, Brazil tried to counter balance and reverse the land statute issued in 1964. Under that statute, the Brazilian Amazon became open access land for settlers, who were allowed to claim land after initially 10 and later 5 years of cultivation (Araújo et al. 2009, Hargrave et al. 2013), something that became a strong incentive for clearing forest. The paper compared the later environmental policies with each other designed to curb deforestation. It examined the marginal effect of these overlapping environmental policies on the decline in deforestation, determining their relative share at protecting forests.

The section will start out with a review of the underlying theory and literature, explain the methods and data used, present the analysis and results, and draw conclusions.

\subsection{Theory and Literature ReView—Linking Environmental Policies WITH DEFORESTATION}

\subsubsection{Context}

Chapter four introduced five of the eight environmental policies used in our model. Specifically, I introduced (1) strictly protected areas, (2) sustainable use areas, (3) indigenous territories, (4) enforcement by IBAMA, and (5) blacklisting (or public disclosure). Here I add (6) access to credit restrictions, (7) the Soy Moratorium, and (8) the rural cadaster system (CAR) ${ }^{88}$ Please refer to chapter four for a description of the theoretical pathways for the first five policies. Here I add policy 6 (rural credit restriction), policy 7 (Soy Moratorium), and policy 8 (rural cadaster system).

The Brazilian National Monetary Council (Conselho Monetário Nacional, CMN) introduced Resolution 3.545 in 2008. This resolution provides access to rural credit only to those farmers that comply with the Forest Code and with legal and environmental regulations. The policy mechanism thus restricts access to rural credit for farmers. Assunção et al. (2013, p. 4) find that "Resolution 3,545 led to a reduction in the concession of rural credit in billion (USD1.4 billion) were not loaned in the 2008 through 2011 period due to restrictions imposed by Resolution

\footnotetext{
${ }^{88}$ The papers describing the effect of these policies had different outcome variables so that I was not able to determine the effect size in Chapter 5 .
} 
3,545." Thus, in the credit-constrained environment of the Brazilian Amazon, credit restrictions seem to be an effective policy instrument to reduce deforestation.

The Soy Moratorium is a private sector policy and an agreement among major soybean traders. It limits demand from big retailers for soy grown on land that was cleared after mid-2006 (Cisneros et al. 2015). The assumed effect of the policy is that farmers and distributors change behavior and that farmers do not plant soy on land cleared after 2006. The policy mechanism consists of an agreement between major retailers, NGOs, and soybean traders "agreeing not to purchase soy grown on lands deforested after July 2006 in the Brazilian Amazon," according to Gibbs et al. $(2015$, p. 1). They conclude in their article that "in the 2 years preceding the agreement, nearly 30 percent of soy expansion occurred through deforestation rather than by replacement of pasture or other previously cleared lands" (Gibbs et al. 2015, p. 1). After the moratorium, "deforestation for soy dramatically decreased, falling to only $\sim 1 \%$ of expansion in the Amazon biome by 2014" (Gibbs et al. 2015, p. 1). Thus, according to Gibbs et al. 2015, the Soy Moratorium is an effective mechanism to reduce deforestation.

As stated earlier, the rural cadaster system (CAR), clarifies land rights and monitors and enforces compliance with Brazil's Forest Code. With respect to the expansion of the rural cadaster system (or the initial Mato Grosso system for the environmental licensing of rural properties, SLAPR), evidence from two evaluations suggests that this policy increases deforestation rather than reducing it (Rajão et al. 2012, Azevedo A. et al. 2014, and Gibbs et al. 2015). The states of Mato Grosso and Pará piloted the CAR policy by mandating farmers to register their land, clarifying land disputes, and abide by Brazil's Forest Code by preserving 80 percent of their forest as natural reserves and reforesting along rivers and springs. This way, the state governments were able to better monitor compliance with the Forest Code and to hold property owners to account for illegal deforestation.

The mechanism used for the CAR policy is clarifying land rights and monitoring and enforcing compliance with the Forest Code. According to Rajão et al. (2012, p. 237), in SLAPRregistered properties in Mato Grosso, "40 percent of [deforestation] was carried out illegally (i.e., inside legal reserves) and 60 percent legally (i.e., with the authorization issued by the state government). This suggests that SLAPR was not only unable to offer a significant reduction in deforestation, but, in some cases, also stimulated its increase." Azevedo et al. (2014) analyzed the results of the CAR system in Mato Grosso and Pará of 49,669 rural properties over the period 2008-2012. They find that even though the CAR system was successful in registering 
rural properties in both states, "the lack of a clear effect of CAR in large properties and the loss of the positive effect in the last few years, indicates that this success can be limited and short lived" (Azevedo et al. 2014, p. 14). Similarly, Gibbs et al. (2015, p. 1) note that "in 2014, for example, nearly 25 percent of Amazon deforestation in Mato Grosso and 32 percent in Pará occurred within registered properties.” Azevedo et al. 2014 make a lack of monitoring and accountability responsible for the failure of the CAR in reducing deforestation.

So far, none of the few papers on the CAR system have been able to describe a positive effect on reducing deforestation. However, the papers did not look at the different policies that overlap on the ground.

The section below will describe in more detail the pathways and interlinkages of the different environmental policy mechanisms to achieve the policy targets, also mapped out in Annex C, Table 34.

\subsubsection{Theoretical Impact Pathways of Different Environmental Policy Mechanisms}

With respect to the results framework, this chapter is looking at drivers of deforestation ${ }^{89}$ as referred to in the literature, or factors that can be associated with deforestation. It also examines environmental policies that can be associated with changes in the incentive structure of landholders within a municipality in terms of the landholders' land-use planning decisions of either clearing the forest, or keeping it standing in order to achieve policy targets.

According to the literature, several factors can be associated with deforestation decisions among landholders in the Brazilian Legal Amazon: The closer a road, river, or urban center, the easier the export, the higher the returns, and the more likely landholders will cut down trees (Angelsen and Kaimowitz 1999, Geist and Lambin 2001, Armenteras et al. 2009, Nolte et al. 2013a, Araújo et al. 2009, de Espindola 2012). I control for these drivers of deforestation in our model by focusing on transport costs and include a variable on the world market price for export products normalized by fuel price. In addition, an increasing urban population and higher GDP creates more demand for products, such as beef and soy and provides labor, which

\footnotetext{
${ }^{89}$ Please see definition of "drivers of deforestation" in chapter one. In this chapter, I use the term 'drivers' not in a way that suggests causality, but in terms of factors associated with deforestation. I use the word 'drivers' because it is a term commonly used in the deforestation literature.
} 
lowers costs of the producer (Pfaff 1998). Other drivers of deforestation are fire, temperature, and precipitation, which I also include in our model.

The eight environmental policies have been designed to prevent deforestation and change the incentive structure for landholders. Below, I discuss the way the environmental policies change the incentive structure toward leaving the forest standing and mechanism through which they preserve forest.

Law enforcement missions are designed to lower the incentives for landholders to clear land. Created in 1998, (1) the environmental police (IBAMA) monitor deforestation in the Brazilian Amazon. Since the introduction of INPE's real-time deforestation detection system DETER in 2002, IBAMA monitors real-time deforestation every 15 days and conducts law enforcement missions to selected deforestation hotspots. During its field missions, IBAMA fines and/or arrests offenders, issues embargoes, publicizes lists of embargoed farmers, and seizes and/or destroys production goods and equipment. As highlighted in Cisneros et al. 2015, state-level public prosecutors need to support IBAMA missions at the local level to ensure that fines are collected and that production goods are seized. Political interference needs to be avoided at every step of the impact pathway to lead to reduced deforestation.

Among other areas, IBAMA and ICMBio monitor and conduct enforcement missions in three types of protected areas, (a) strictly protected areas, (b) sustainable use areas, and (c) indigenous territories. In these areas, the incentive structure is designed to keep landholders and illegal loggers away. The mechanism through which protected areas work is by either keeping people and economic activities out of the designated park area and thereby protecting forests (strictly protected areas), or by allowing sustainable subsistence activities (sustainable use areas and indigenous territories). In all three cases, either the protected area staff, or people living in the reserves monitor and protect the forest against illegal deforestation and forest fires, which in turn leads to forest being preserved. One caveat brought up in the literature is that protected areas are often unsuitable for economic activity and would not have been developed even in the absence of a protected area (Börner and Wunder 2008, Gregersen et al. 2010, Ferraro 2011, Alix-Garcia et al. 2012, Muradian et al. 2012, Wunder 2013, and Ferraro et al. 2015). Another argument brought forth by the literature is that protected areas will dislocate economic and agricultural activities to other areas (Armenteras et al. 2009, and Buntaine et al. 2015). 
The second phase of the Plan to Combat Deforestation in the Amazon (PPCDAM 2007-2011), instituted the three interlinked policies of blacklisting, restrictions on credit access, and the environmental registry system, CAR. The following paragraphs will describe impact pathways for these three policies.

Presidential Decree 6.321 of December 2007 introduced the blacklisting policy. The policy creates strong incentives for landholders and municipalities to stop deforestation. Every year, all the municipalities in the Amazon biome, to which the policy applies, are examined with respect to their deforestation record over the past three years. The analysis is based on INPE's real-time deforestation detection system DETER. Communities with the largest total area deforested, the largest deforested area over the past three years (Cisneros et al. 2015) are blacklisted. According to Cisneros et al. (2015), blacklisting increases the administrative burden for the individual farmer, as well as for the municipality, it poses a reputational risk for the municipality, and attracts external pressure and support from NGOs. This leads to municipalities wanting to get off the blacklist, for which municipalities need to register 80 percent of their land under the CAR system and reduce deforestation to below 40 square kilometers per municipality per year, which increases the administrative burden for both municipalities and individual landholders. Landholders in blacklisted communities also face restrictions on credit access, which, in the credit-constrained environment of the Amazon reduces the opportunity to embark on larger-scale agricultural production.

Resolution 3.545 of 2008 restricts access to credit for landholders not complying with Brazil's Forest Code and thus provides strong incentives to refrain from clear-cutting. Landholders will only be able to access credit in the future once they comply with environmental legislation. In the credit-constrained environment of the Brazilian Amazon (Assunção et al. 2013), farmers lack financial resources for medium and large-scale agricultural production. This leads to landholders abiding by the provisions of the Forest Code, which also means registering their property in the CAR system for future monitoring. By restricting access to credit for landholders they are shepherded into complying with the Forest Code, which then reduces deforestation.

Piloted by two states (Mato Grosso and Pará), the rural environmental registry system has been institutionalized for the whole country through the Forest Code (Law 12.651/2012). Until 2016, all rural properties must be registered in the cadaster system. According to the law, landholders with and without formal property rights voluntarily register the size and spatial boundaries of 
their land holdings online (Cisneros et al. 2015). The CAR policy is designed to incentivize farmers to register their landholdings, make their landholdings more transparent, and comply with the Forest Code by halting illegal deforestation. According to the theoretical impact logic of this policy intervention, local, state, and federal agencies monitor ongoing deforestation and can identify offenders of the Forest Code by name and address, according to their registered boundaries in the cadaster system. Offenders face IBAMA fines, credit restrictions, and potentially blacklisting of the municipality and thus are coerced to comply with the Forest Code and refrain from deforestation. A potential caveat highlighted in the literature (Angelsen 2010, Rajão et al. 2012, Assunção et al. 2013, Azevedo et al. 2014, Nepstad et al. 2014) mentions the perverse incentive of the CAR system to compel landholders to deforest more land before registering to claim more land.

The last public policy here under review is the Soy Moratorium. Unlike the other policies, the moratorium is not a government policy. Rather, it is the result of cooperation between the private sector, NGOs, and government institutions. The Soy Moratorium creates an incentive for landholders not to clear-cut new areas for soy plantations because of limited demand for products grown on newly clear-cut land. After pressure from major NGOs, soybean traders signed the Soy Moratorium in 2006, limiting demand for soy crops grown on land cleared before 2006. According to the theoretical impact logic, the industry, NGOs, and the government monitor farmers using satellite images and airplanes and block offenders selling to Soy Moratorium signatories. The Soy Moratorium is a supply-side mechanism that compels producers, traders, and international and national buyers to comply with the Forest Code and thus reduce deforestation. A caveat of this policy highlighted by the literature (Gibbs et al. 2015 ) is that soy production may be displaced to the Cerrado, a region outside the Amazon biome to which the Soy Moratorium does not apply.

In conclusion, all eight polices were designed to limit the incentives of the individual landholder within the Brazilian Legal Amazon to clear-cut more land.

The section below will map the links among the policies to highlight their reinforcing effects.

\subsubsection{Interlinkages between the Eight Environmental Policies}

Figure 22 shows the theoretical degrees of overlaps of the eight environmental policies. It demonstrates that the areas to which a specific environmental policy applies are different in size and location. Figure 22 does not capture this overlap in a precise, geographical sense, and 
it misses out on the time dimension. Rather, it captures the theoretical overlap that will be discussed further below. Discussing the overlap on the ground is important given that it may introduce biases in our statistical estimates. My model distills the marginal effect of the overlapping policies, but not their individual effect size.

\section{Figure 22. The overlapping environmental policies in the Brazilian Amazon}

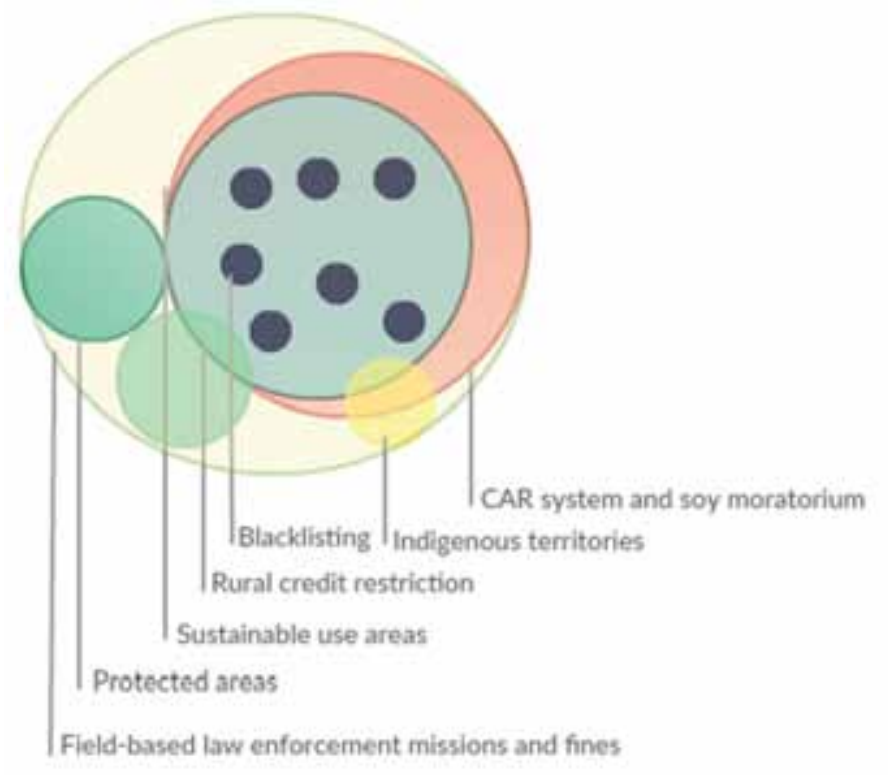

Figure 23, and the more elaborated form in the Annex, Figure 25, develop a results framework for the impact pathways of eight environmental enforcement and access restriction policies. They show that the IBAMA law enforcement monitors the protected areas that preserve the forest. Residents that do not live in a protected area (either strictly protected, indigenous territory, or sustainable use) also protect the forest when they adhere to Brazil's Forest Code. IBAMA uses enforcement actions. Blacklisting, access to credit restriction tied to the offense against the Forest Code, and voluntary rural registry of forested areas are all part of a policy system to incentivize and coerce people in adhering to the Forest Code. The Soy Moratorium follows the same logic. 
Figure 23. Impact pathways of eight environmental enforcement and access restriction policies

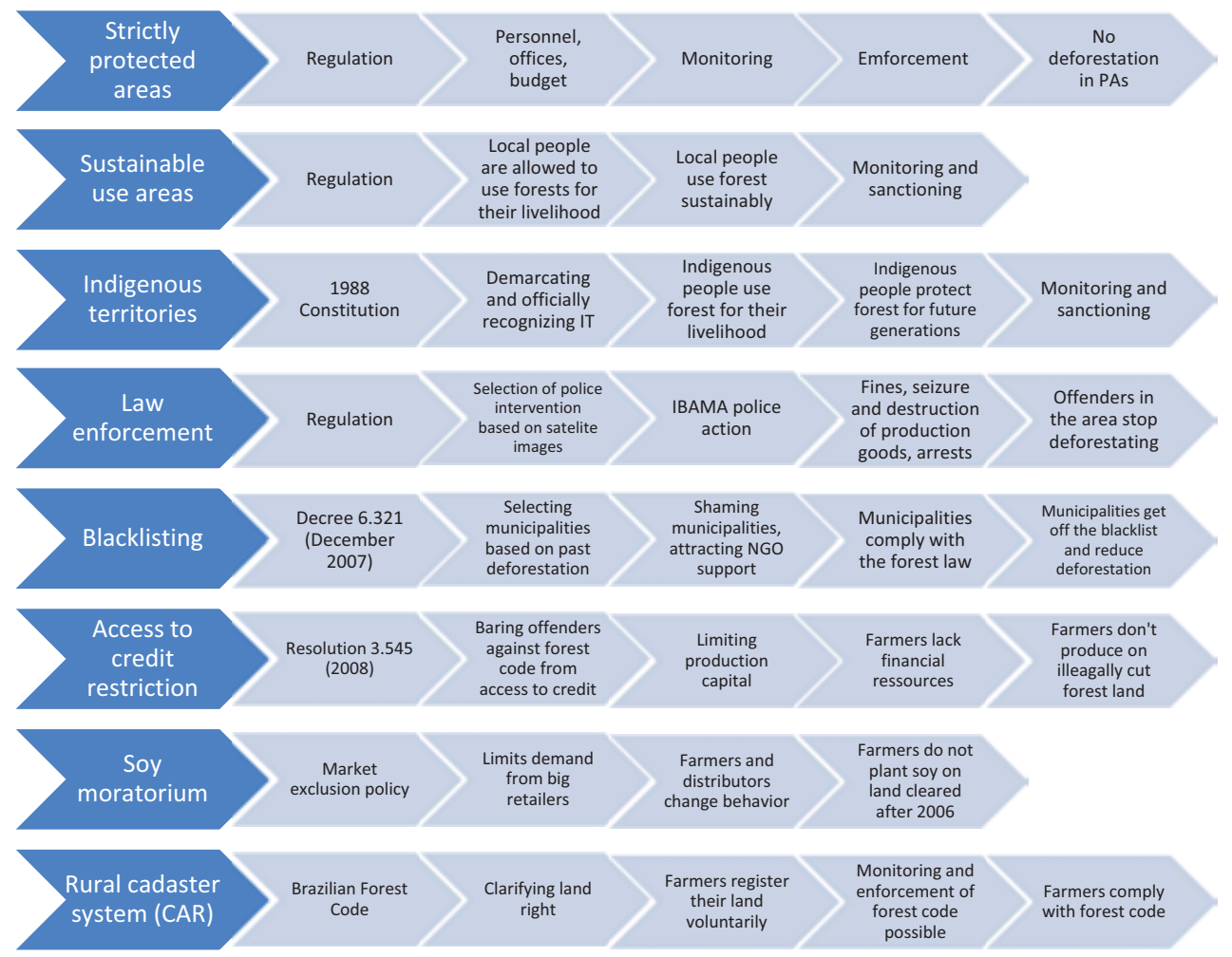

According to my results framework (Figure 23 and Figure 25), IBAMA's real-time monitoring and field-based enforcement missions are the basis for the different environmental policies to be effective (green-yellow circle in the Venn diagram, Figure 22). IBAMA monitors protected areas, supported and informed by local rangers, indigenous peoples, and forest dwellers living in the sustainable use areas. The fact that IBAMA monitors all areas in the Amazon biome via satellite imagery taking local information into account makes us consider the treatment levels to be homogenous. Sustainable use areas and indigenous peoples comply with the CAR system and may face credit restriction in the unlikely case that they do not comply with the Forest Code. It is unlikely as well that protected areas overlap with blacklisted communities (Cisneros 2015). IBAMA also monitors areas outside the protected areas. Here the trilogy of policies (blacklisting, access to credit restriction, and CAR system) initiated under the PPCDAm II program applies. The Venn diagram (Figure 22) illustrates them as a red and a blue circle with black dots. The circles do not overlap perfectly, since the blacklisting policy applies only to the 
Amazon biome, whereas the CAR system applies to all rural properties in the whole of Brazil. In a similar vein, the Soy Moratorium applies not only to the Amazon biome but to the whole Amazon region, which encompasses more municipalities than the Amazon biome. All four policies contribute to landholders and municipalities complying with Brazil's Forest Code.

Before I present the model, I will discuss the approaches and limitation of studies in the literature that modeled deforestation using spatially explicit data in econometric models.

\subsection{ECONOMETRIC MODELS ON DEFORESTATION IN THE LITERATURE}

A recent meta-analysis reviews 121 spatially explicit econometric studies on deforestation from different regions in the world useing quantitative metrics to compare the relative influence of different drivers of deforestation (Busch and Ferrretti-Gallon 2017). The use of the term "drivers of deforestation" is anchored in the deforestation literature going back to Geist and Lambin (2001). The meta-analysis finds that the econometric studies focused on economic drivers of deforestation. The meta-analysis includes only studies that used geospatial data, focused on forest cover or forest cover loss as the outcome variable, and were published in peer-reviewed journals. The meta-analysis includes studies between 1996 and 2013 and identifies a total of 1,480 explanatory variables linked to deforestation. These drivers of deforestation are broadly economic in nature, such as market demand for commodities (e.g., agriculture and timber production), built infrastructure (e.g., proximity to roads, proximity to urban areas), demographic and socioeconomics characteristics (e.g., age, education, and property size), ownership and management rights (e.g., protected areas, law enforcement, community forest management, land tenure security), as well as biophysical characteristics, (e.g., slope, elevation, wetness, soil suitability, distance to water).

Results of the meta-analysis show that the main drivers of deforestation are related to agriculture and pasture in lowlands and in proximity to roads or other transportation systems. For Brazil's agriculture sector, the meta-analysis highlights findings from Arima et al. (2011) and Hargrave and Kis-Katos (2012) for example. In addition, the meta-analysis identifies large populations consistently as a driver of deforestation, although the causality of this relationship was difficult to interpret because of endogeneity (Busch et al. 2017).

Surprisingly, timber production, land tenure security, and community demographics do not show any consistent trend as drivers of deforestation. For example, Araújo et al. (2009) find for Brazil that secure property rights reduced deforestation, while studies in other countries do 
not. Interestingly, poverty is a strong indicator of lower deforestation, according to the metaanalysis. With respect to poverty as well as population, the meta-analysis warns that because of possible endogeneity both population and poverty could influence deforestation outcomes, as well as the other way around.

A few studies also examine the influence of individual policies, such as protected areas, the presence of indigenous peoples, community management of forests, enforcement policies, and PES. However, and relevant to this chapter, the meta-analysis was not able to systematically assess the influence of environmental policies on deforestation because of a lack of studies during the 2000s. The meta-analysis states, "the strong and consistent effect of market demand for agricultural commodities on deforestation suggests that policies that can successfully insulate the forest frontier from the influence of high commodity prices have great potential to reduce deforestation. However, most of these types of policies (e.g., corporate supply chain commitments, certification schemes, moratoria on agricultural concessions, agricultural credit restrictions) had not been rigorously evaluated as of 2013, and thus we have not assessed them here" (Busch et al. 2017, p. 15). In this chapter, I aim to analyze the association between policy variables and deforestation by using a model of deforestation, not a meta-analysis. The analysis compiles relevant explanatory variables for eight environmental policies of Brazil. It then estimates the marginal effect of these policies that can be associated with deforestation (but is not designed to estimate any causal relationships for individual environmental policies and deforestation).

As noted earlier, the literature points to problems with endogeneity in econometric models of deforestation. Busch et al. (2017) test for and confirmed the absence of several biases, such as location bias, selection bias, sample bias, and publication bias. The meta-analysis also highlights endogeneity bias in some of the variables where the direction of what influences what was not clear. Endogeneity is thus a problem in many of the spatially explicit econometric models that has not yet been addressed satisfactorily in the literature. Our model encounters the same problem, although we attempt to minimize it. Future research will have to find solutions and address endogeneity in deforestation models, but this will be outside of the scope of this current research. 


\subsection{Methodology-Using a Panel Model to Account for Policies as DRIVERS OF FOREST CONSERVATION}

\subsubsection{Measurement of Indicators}

We employ a panel data approach that uses the municipality as the unit of analysis $(n=523)$ for 10 years (2003-2012). We derive the data and borders from the IBGE.

For our outcome measure, this section uses the area deforested for a particular municipality and year. We downloaded deforestation data in square kilometers from INPE-PRODES and corrected for cloud error (following Cisneros et al. 2015), using data from 2003 to 2012. Correcting for cloud error is important. In daily satellite data, parts of the Amazon forest are covered with clouds and, therefore, deforestation that happed on one particular day in that year and area covered by clouds cannot be detected. It may only be detected in a later year. Cisneros et al. (2015) found a statistical way to correct for cloud cover in the Brazilian Amazon, which was included in the model as cloud error.

We obtained treatment data for the eight different policies from different sources as explained in the paragraphs that follow. To measure the effectiveness of protected areas in curbing deforestation, we use (1) strictly protected areas, (2) sustainable use areas, and (3) indigenous territories. We measure protected areas in square kilometers per municipality and year using data and borders from IBAMA for all three types of protected areas. We expect protected areas to have a negative effect on deforestation, however, if protected area expansion during our observation period has taken place primarily in areas with high deforestation pressure, selection bias may (mis-) lead us to observe none or positive effects on deforestation. If the expansion of protection on the other had focused on low-pressure areas, we would overestimate the conservation impact. We address this selection bias by including a baseline forest cover variable from 2002, in addition to other control variables.

To measure the effect of the enforcement policy, we use the number of fines per municipality and year issued by IBAMA to fine illegal felling in the Amazon. While this variable does not capture all IBAMA activities, it is a useful proxy and underestimates the effect of this policy, rather than overstating it. We expect the enforcement policy to have a negative effect on deforestation. Measuring enforcement policy using the number of fines per municipality could include the risk of being endogenous and introduce selection bias. IBAMA enforcement actions 
and fines are likely to be partially "caused" by the level of deforestation, rather than (or in addition to) causality running from number of fines to deforestation. We therefore normalize the number of fines by the area that was forested in 2002 as a baseline and use control variables in our model, such as the distance to the capital city Brasília where IBAMA is located, population density, settlement areas, area covered by clouds, among others that tend to affect deforestation and inspection (Assunção et al. 2013 and Börner et al. 2015).

We measure the blacklisting policy by a dummy variable turning 1 for the year(s) that a municipality has been listed on the blacklist embargo (50 municipalities have been listed and only 6 have been removed between 2008 and 2012, Cisneros et al. 2015). We expect the blacklisting policy to have a negative effect on deforestation. Here as well, we need to guard against selection bias. The blacklisting of municipalities or public disclosure is explicitly based on past deforestation. As with the IBAMA fines policy, blacklisting affects those municipalities with high deforestation. Here as well, high deforestation could lead to blacklisting, or alternatively, the blacklisting policy could reduce deforestation. We address selection bias by normalizing the variable with the area forested in 2002 as our baseline forest cover. Control variables, such as land price, soy price, heads of cattle, among others are often associated with deforestation. Their bias would lower the estimated effect on deforestation rather than increasing it. In addition, given the high spatial overlap with some of the other treatment variables, we also interact blacklisting with the area registered under the CAR system, IBAMA fines, and the total amount of rural credits.

We measure data for the credit restriction policy in an indirect way, by using the total amount of public rural credit by municipality and year from the National Institute of Colonization and Agrarian Reform (INCRA). This variable is not directly related to policy, but we expect policy to affect the amount of public rural credit. The credit restriction policy only applies to the municipalities within the Amazon biome, but not to the municipalities in the wider Amazon region. Therefore, we interact this variable with a variable that captures the municipalities in the biome. We expect the variable total number of rural credits per year to have a positive effect on deforestation as the amount of credit increases. In the credit-constrained area of the Amazon, additional financing would increase investments in agricultural production and thus deforestation. To measure the effect of rural credit restriction, we would expect the total number of rural credit to decrease along with deforestation. Our variable 'yearly amount of rural credit' could be biased through high or low demand for rural credit (Hargrave and Kis- 
Katos 2013). This could lead to upward or downward bias of the effectiveness of the policies. However, given the findings of Assunção et al. (2015) about the credit constraint Amazon region, our estimates will be rather conservative. We expect the policy to limit access to rural credit for forest code offenders and thus discourage deforestation. Given the overlap with other environmental policies we use interactions to account for the overlap.

This paper measures the Soy Moratorium using the area that is suitable to plant soy. The data are available at the IBGE and are measured in square kilometers. An interaction with the year 2007 and the biome specifies the year in which the Soy Moratorium was instituted and the municipalities to which the moratorium applies. We expect the Soy Moratorium to have a negative effect on deforestation. Our variable of 'soy-suitable area' could be biased by the price of soy and other agricultural commodities, demand for soy products, transportation costs, etc. We control for these variables in our model. However, unobserved factors may still bias our results.

The CAR system incentivizes farmers to voluntarily report their property in the georeferenced rural cadaster system. We estimate the effect of this policy by using the area in square kilometers per municipality and year registered under the CAR system. Given the spatial overlap of the different policies, we interact this variable with some of the others mentioned above. We expect the CAR system to have a negative effect on deforestation if the policy is effective. As with protected areas, if the registration of conservation areas took place primarily in areas with high deforestation pressure, selection bias may (mis-) lead us to observe none or positive effects on deforestation. If, on the other hand, the registration of conservation area focused on low-pressure areas that would have been preserved anyway, we would overestimate the conservation impact. In addition, the variable does not capture the perverse incentive mentioned in the literature (Rajão et al. 2012, Assunção et al. 2013a, Azevedo et al. 2014, Nepstad et al. 201) to clear-cut forest before registration to claim more land.

Covariate data were collected using a variety of sources. Among them is the meta-analysis of Busch et al. (2017), discussed earlier, who compare the relative influence of different drivers of deforestation based on 121 spatially explicit econometric studies. We use a total of 15 control variables for our model. These control variables range from cloud error adjusting for measurement errors in the deforestation dataset (see Cisneros et al. 2015) to mean temperature and mean precipitation from PRODES, the area covered with settlements, forest price, soy price, timber price, the number of cattle, agricultural GDP per capita, and general GDP per 
capita. These variables correspond to the ones described by Bush et al. (2017) as influencing deforestation outcomes. In addition, we use four interaction terms where each year is interacted with the $(\log )$ distance to the capital, the area forested in 2002 as baseline, the population density in 2000 as another baseline, and the share of farms without a title, as a measure for unofficial settlements often linked to deforestation.

This chapter uses a panel model to estimate deforestation outcome. In the past, the literature has published some models predicting deforestation (see chapter four), but none of these models included more than one or two policy variables to explain the decline in deforestation in the Brazilian Amazon. In the past, policy variables have been considered irrelevant. However, given the dramatic decline in deforestation since 2004 that coincides with the introduction of environmental policies (see Figure 4), these environmental policies can no longer be ignored.

One limiting factor of this model is that it does not provide us with estimates for the true decline in deforestation. According to Gelman and Hill (2007, p. 192), "questions such as "What proportion of the treatment effects works through variable A?' are inherently unanswerable." Therefore, we limited our research at determining a relative share and not the cause or effect of the decline in deforestation.

\subsubsection{Data Models}

We estimate the marginal effect of overlapping environmental policies as drivers associated with deforestation by employing a panel structure drawing from annual data at the municipality level. Given that we have non-experimental data, and treatment has been non-randomly assigned, we first use a fixed effects model to control for "variables that have not or cannot be measured" (Allison 2009, p. 1). The fixed effects model uses each municipality, as its own control (Allison 2009). The fixed effects model addresses some of the endogeneity concerns due to unobserved effects that the literature highlights and that we discussed earlier. However, the fixed effects model cannot control for unobserved variables that vary over time (Allison 2009). Given that deforestation in each municipality changes over time, we will also use a first difference model. The first difference model will exploit the over-time (within) variation (Andre $\beta$ et al. 2013). In addition, and similar to the fixed effects model, the first difference model will also remove municipality fixed effects.

As a first step and using our dataset, we estimate the following equation: 
Model 1: $\quad D e f_{i t}=\lambda_{t}+\alpha_{i}+t Z_{i} \beta_{1}+X_{i t} \beta_{2}+\beta_{3} C_{i t-1}+\gamma_{1} S_{i t}+\gamma_{2} I T_{i t}+\gamma_{3} S P A_{i t}+$ $\gamma_{4} M U A_{i t}+\gamma_{5} B_{i t}+\gamma_{6} F_{i t} B_{i t}+\gamma_{7} C A R_{i t-1}+\gamma_{8} C A R_{i t-1} B_{i t}+\gamma_{9} C_{i t-1}+\gamma_{10} C_{i t-1} \Omega_{i}+$

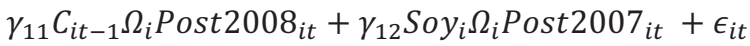

In this model, $D e f_{i t}$ is the newly deforested area in municipality $\mathrm{i}$ in year t. $\alpha_{i}$ are the unobservable fixed effects that can be associated with deforestation. They will be eliminated through the first differencing and demeaning in our fixed effects and first difference estimations. The betas are coefficients for our control variables; the gammas are coefficients for our environmental policy variables.

$Z_{i}$ are observable characteristics and initial conditions of deforestation (i.e., initial period variables that would be expected to impact on future trends in the outcome variable). We chose to include the "share of area covered by forest in 2002" and "population density in 2000" as baseline conditions on which future deforestation will depend. We believe these can be associated with deforestation trends over our period based on the literature discussed above. We choose to include them in our first difference model only. To include them, we interact these observable initial conditions with the time variable. That way, after first differencing the dataset, the unobservable time fixed effects will stay in the estimation model in our first difference model, but not in our fixed effects model. The literature describes this technique as "initial conditions." According to Jalan and Ravallion (1998), "models in which the first difference of a variable depends on initial conditions have been popular in recent literature testing endogenous growth models" (Jalan and Ravallion 1998, p. 67). This technique helps us to keep the effect of, for example, larger communities in the model.

Furthermore, $X_{i t}$ are observable time variant characteristics that can be associated with yearly deforestation, i.e., cloud cover (lagged and the same year) as well as mean temperature and mean precipitation.

In terms of our environmental policies, $\mathrm{C}_{\mathrm{it}}$ control for annual public credit issued; $\mathrm{S}$ it controls for $\log$ settlement area; $\mathrm{IT}_{\mathrm{it}}$ for indigenous territory area; SPA $\mathrm{A}_{\mathrm{it}}$ for strictly protected area; MUA $_{i t}$ for multiple-use protected area; $B_{i t}$ for a dummy variable on blacklisting, turning 1 in the year a municipality is set on the blacklist; $B_{i t}$ times $F_{i t}, F_{i t}$ represents the number of fines. The coefficient measures the additional effect of fines in municipalities when they are blacklisted; and $\mathrm{CAR}_{\text {it }}$ controls for annual share of area registered under the CAR policy. In 
addition, the coefficient $\mathrm{CAR}_{\text {it }}$ times $\mathrm{B}_{\text {it }}$ captures the additional effect of land registration and the CAR policy on deforestation after a municipality has been blacklisted.

Furthermore, $\mathrm{C}_{\mathrm{it}-1}$ represents lagged number of public credit issued in a municipality; $\mathrm{C}_{\mathrm{it}-1}$ times omega (where omega represents a dummy for municipalities that are within the Amazon biome), controls for the fact whether a municipality is located within the Amazon biome or not and thus whether certain environmental policies apply or not. The coefficient measures if there is a differential effect of credit between the Amazon biome and the Cerrado biome, as relevant for the Soy Moratorium.

$\mathrm{C}_{\mathrm{it}-1}$ times omega times Post2008 is the coefficient that measures if there is a shift in the effect of credit in the Amazon biome after the credit restrictions were implemented in 2008.

Finally, Soyi controls for soy-suitability area; Soyi times omega times post2007 dummy measures whether there is a shift in deforestation due to the Soy Moratorium-implemented in 2007 - according to the potential soy profits in the municipality.

We simplify the above equation as follows:

$$
\widetilde{D e f_{l t}}=\lambda_{t}+\alpha_{i}+t Z_{i} \beta_{1}+X_{i t} \beta_{2}+P_{i t} \gamma+\epsilon_{i t}
$$

Where $\widetilde{D e f_{l t}}$ represents the time demeaned newly deforested area in municipality $\mathrm{i}$ in year $\mathrm{t}$ and $\lambda_{\mathrm{t}}$ is an intercept that may be different for each year. The $\alpha_{i}$ are the unobservable fixed effects that can be associated with deforestation. $t Z_{i}$ represent observable time invariant characteristics of deforestation interacted with the time variable. ${ }^{90} C_{i t}$ controls for annual public credit issued and is now part of $X_{i t}$ and all policy variables are summarized in $P_{i t} \gamma$. The $\epsilon_{i t}$ is the error term.

\section{Fixed Effects Model}

We estimate our time-demeaned fixed effects model equation as follows:

$$
\widetilde{D e f_{l t}}=\lambda_{t}+\widetilde{X_{l t}} \beta_{2}+\widetilde{P_{l t}} \gamma+\widetilde{\epsilon_{l t}}
$$

\footnotetext{
${ }^{90}$ This will be only relevant for our first difference estimates. We will explain the method based on Jalan and Ravallion (1998) further under the section on first difference.
} 
Where $\widetilde{D e f_{l t}}$ represents the time demeaned newly deforested area in municipality $\mathrm{i}$ in year $\mathrm{t}$. The tilde indicates "time demeaned" here and in the remainder of the model. $\lambda \_t$ is an intercept that may be different for each year. $\widetilde{X_{l t}}$ represents the observable time variant characteristics that can be associated with yearly deforestation (i.e., cloud cover, mean temperature, and mean precipitation). $\beta_{2}$ are coefficients for our control variables; $\widetilde{P_{l t}} \gamma$ represent coefficients for our environmental policy variables, and $\widetilde{\epsilon_{l t}}$ is our error term.

We estimate the fixed effects equation without initial characteristics of $Z$ that will become relevant only in the first difference equation.

Following the fixed effects method, the unobservable time fixed effects, alpha_i, are being excluded by subtracting the mean from each variable within each observation.

We use a fixed effects model to estimate each policy's marginal contribution to the reduction in deforestation. By using the fixed effects model, we keep time constant and solely examine levels, i.e., we examine if these policies have affected the area deforested. However, changes in the environmental policy variables could be correlated over time. In other words, what happens in time period one could be correlated with what happens in time period two. We therefore use the first difference model to also control for time variant unobservable variables. Future research will determine how much of a factor correlation, and especially autocorrelation really plays.

We will discuss results after presenting the first difference model and data sources.

\section{First Difference Model}

We estimate our first difference model equation as follows:

$$
\Delta D e f_{i t}=\lambda_{t}+Z_{i} \beta_{1}+\Delta X_{i t} \beta_{2}+\Delta P_{i t} \gamma+\Delta \epsilon_{i t}
$$

We follow the approach taken by Jalan and Ravillon (1998) and include initial characteristics $\mathrm{Z}$ (observable initial conditions that can be associated with deforestation), and interact them with $t$ in our data model so that they remain in the dataset after first differencing. As with the fixed effect model, unobservable time fixed effects, $\alpha_{i}$, are excluded by first differencing the data. The lagged variables in our model help reduce endogeneity. According to Allison (2009, p. 6): “There is nothing to prevent the $X_{i t}$ vector from including lagged versions of the $X$ variables." Our first difference model estimates the change in deforestation by calculating the 
interval for each municipality between one year and the next, and repeats this for the different years.

Comparing the efficiency of the two models is difficult, given that no specific test exists (Allison 2009). The fixed effects model is more robust to strict endogeneity violations compared with the first difference model. Given possible endogeneity between municipality fixed effects and explanatory variables, we initially expected the fixed effects model to be more efficient in explaining the variance in the decline (Angrist and Pischke 2009). However, given that auto-correlation plays a large role in deforestation models (meaning that when one area is deforested it is likely that neighboring areas are also being deforested), we expect the first difference model to be more efficient in explaining the variance in the decline in deforestation in the Brazilian Amazon.

\subsubsection{Principal Component Analysis}

We also use Principal Component Analysis (PCA), to reduce the complexity of the dataset that includes eight policy variables all designed to reduce deforestation. Our fixed effects and first difference models are prone to encounter significant issues of multicollinearity, which can affect standard errors. We may also encounter policies to work in combination (i.e., policy A on its own is ineffective, but when combined with policy B affects the extent of deforestation). The approach of including eight alternative variables does not allow for this - given it estimates the effect of a variable holding all else constant. PCA does not solve the multicollinearity issue of our model. In addition, it assumes that the covariance of the policy variables does not change over time. PCA shows, however, which policy variable may have the largest influence on a PCA-based policy index variable.

We therefore also combine the eight different variables into a single policy variable, PC1, with higher values indicating more (and a higher intensity) of policy variables. We use PCA to achieve this. According to Dunteman (1989, p. 7), "principal component analysis is a statistical technique that linearly transforms an original set of variables into a substantially smaller set of uncorrelated variables that represents most of the information in the original set of variables."

Figure 24 visualizes the variation of our eight policy variables. According to Dunteman (1989, p. 7), "principal components analysis has no underlying statistical model of the observed variables and focuses on explaining the total variation in the observed variables on the basis of the maximum variance properties of principal components." Figure 24 shows the contribution 
of each of our eight policy variables. The most significant contribution comes from the first component, the second most significant component from the second one, and the later variables do not add further variable provide very little information to the system. Therefore, PCA focuses mainly on the first components.

Figure 24. Plot of Eigenvalues of eight environmental policy variable correlation matrix

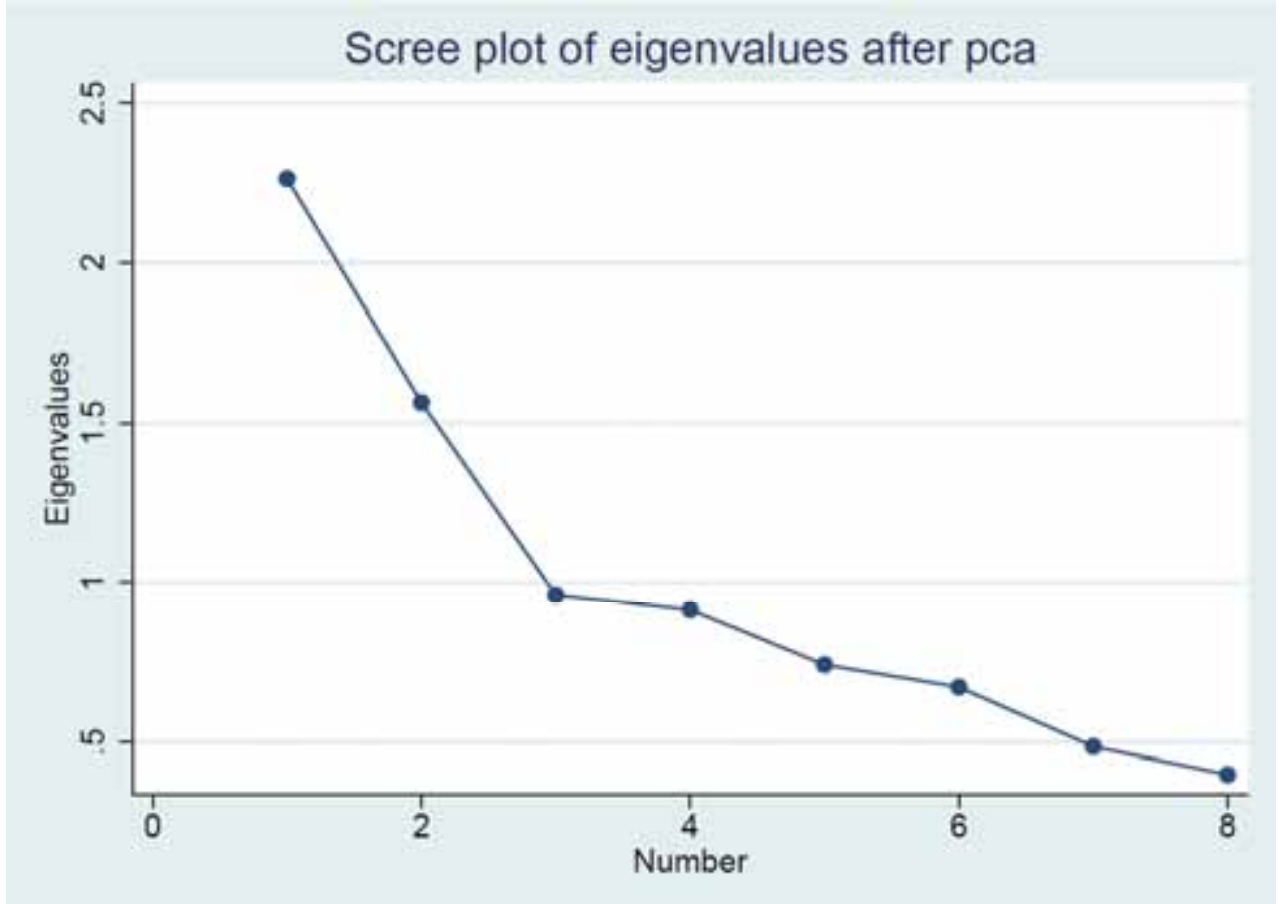

We list the coefficients for the principal components in Table 29 and we notice that some of the coefficients are much more important than the others. In terms of our principal component one, it is mainly a combination of the variables access to rural credit restriction (coef. 0.5299), the Soy Moratorium (coef. 0.4274), and rural environmental registry (coef. 0.3752). 
Table 29. Principal components for environmental policy variables

\begin{tabular}{|c|c|c|c|c|c|c|c|c|}
\hline Variable & Comp1 & Comp2 & Comp3 & Comp4 & Comp5 & Comp6 & Comp7 & Comp8 \\
\hline $\begin{array}{l}\text { Indigenous } \\
\text { territory } \\
\text { (lagged) }\end{array}$ & 0.2155 & 0.3246 & 0.6737 & -0.3917 & -0.1568 & 0.4066 & 0.2236 & -0.0317 \\
\hline $\begin{array}{l}\text { Strictly } \\
\text { protected area } \\
\text { (lagged) }\end{array}$ & -0.0886 & 0.3619 & 0.3208 & 0.8484 & -0.0048 & 0.1197 & -0.1291 & 0.0864 \\
\hline $\begin{array}{l}\text { Sustainable } \\
\text { use area } \\
\text { (lagged) }\end{array}$ & -0.3751 & 0.2596 & -0.1123 & -0.1362 & 0.8003 & 0.2893 & 0.1380 & 0.1324 \\
\hline $\begin{array}{l}\text { Number of } \\
\text { fines by } \\
\text { IBAMA } \\
\text { (lagged and } \\
\text { logged) }\end{array}$ & 0.2821 & 0.5799 & -0.2041 & -0.0144 & 0.1253 & -0.3369 & 0.0864 & -0.6369 \\
\hline $\begin{array}{l}\text { Dummy of } \\
\text { blacklisted } \\
\text { municipalities }\end{array}$ & 0.3481 & 0.4153 & -0.4500 & -0.1242 & -0.1655 & 0.3146 & -0.4287 & 0.4222 \\
\hline $\begin{array}{l}\text { Access } \\
\text { restriction to } \\
\text { rural credits } \\
\text { (lagged and } \\
\text { logged) }\end{array}$ & 0.5299 & -0.0268 & -0.0377 & 0.1617 & 0.1912 & -0.2605 & 0.6003 & 0.4755 \\
\hline $\begin{array}{l}\text { Rural } \\
\text { environmental } \\
\text { registry } \\
\text { (CAR); } \\
\text { (lagged and } \\
\text { logged) }\end{array}$ & 0.3752 & -0.3696 & -0.2202 & 0.2514 & 0.1188 & 0.6443 & 0.1331 & -0.4049 \\
\hline $\begin{array}{l}\text { Soy } \\
\text { Moratorium } \\
\text { (interacted } \\
\text { with the } \\
\text { Amazon } \\
\text { biome and the } \\
\text { year 2007) }\end{array}$ & 0.4274 & -0.2240 & 0.3695 & -0.0567 & 0.4911 & -0.2029 & -0.5873 & -0.0075 \\
\hline
\end{tabular}

Principal component analysis shows that the environmental policies that were introduced more recently provide much more information in the system than some of the other ones. We will come back to this point when discussing results. 


\subsection{Data ANd Summary Statistics-InTroducing Policy Variables and THE DEFORESTATION MODEL}

\subsubsection{Data Sources}

We use ten years of deforestation data (2003-2012) from INPE-PRODES for a total of 523 municipalities in the ten states of the Brazilian Legal Amazon (see Annex B, Table 35). The Brazilian National Institute for Space Research (INPE, Portuguese acronym) and its research project PRODES publishes yearly deforestation estimates. ${ }^{91}$ Following Cisneros 2015, we use the PRODES deforestation data and correct for cloud error. We use municipality borders from the Brazilian census bureau (IBGE) from 2007 and data on the area designated as protected areas, sustainable use areas, and indigenous reserves for each municipality, including dates and the respective decree number from IBAMA. From the IBAMA website, we also downloaded data on fines imposed during the organization's field-based law enforcement missions. For additions and removals to the blacklist starting in 2008, we consulted the respective Decrees. ${ }^{92}$ We measure the rural environmental registry (CAR) with data provided by the Amazon Environmental Research Institute (IPAM) from October 2013. Our data on rural credit come from Brazil's Central Bank (BCB).$^{93}$ In addition, we received information on the price of soy per municipality soy-suitable areas in Brazil's Legal Amazon from the IBGE. ${ }^{94}$

In terms of our control variables, we received information on mean temperature and rainfall for the years 2003-2012 from the Center for Climatic Research at the University of Delaware, ${ }^{95}$ on population density for the year 2000 and on GDP from the IBGE. We also retrieved data on the area covered with settlements and the share of farms without title from INCRA, on the

\footnotetext{
${ }^{91}$ Retrieved on July 20, 2016, from: http://www.dpi.inpe.br/prodesdigital/prodesmunicipal.php.

92 Between 2008 and 2012, Brazil issued the following blacklisting Decrees for a total of 50 blacklisted municipalities. Decree 6.321/2007 and Provision 28/2008, Provision 102, 203/2009, Provision 66,67,68/2010, Provision 138, 139, 175/2011, Provision 187,322,323,324/2012

${ }^{93}$ Retrieved on July 22, 2016, from: http://www.bcb.gov.br/pt-br/\#!/n/CREDRURAL.

${ }^{94}$ IBGE - Instituto Brasileiro de Geografia e Estatística; Link para download: Retrieved on May 16 from: http://www.sidra.ibge.gov.br/bda/tabela/listabl.asp? $\mathrm{z}=\mathrm{t} \& \mathrm{c}=1612$ (Table 1612).

${ }^{95}$ Center for Climatic Research/Department of Geography/University of Delaware Retrieved in May 2016 from: http://climate.geog.udel.edu/ climate/
} 
number of cattle from IBGE's Agricultural Census. Lastly, we retrieved data for forest and timber price from IBGE-PEVS, and soy price from IBGE-PAM.

\subsubsection{Data Preparation}

We use ten years of deforestation data (2003-2012) for a total of 523 municipalities in the ten states of the Brazilian Legal Amazon (see Annex B, Table 35). Based on IBGE's 2007 definition for boundaries, we obtained the municipality-level data from IBGE's database of 771 municipalities in the Brazilian Legal Amazon. After eliminating those municipalities with less than 10 percent forest cover and those with missing data, 523 municipalities remained for our analysis (Cisneros 2015).

We took the log of the variables with non-linear relationships and outliers and we calculated the percent area of the total area of each municipality for area-based variables for better comparison.

\subsubsection{Summary Statistics}

Table 30 displays descriptive statistics for the outcome and treatment. We used panel data for 523 municipalities over 10 years, which correspond to 5,230 observations. All area measurements and the distance to the capital are provided in kilometers. Prices are in Brazilian Reis. The remainder of the variables are numbers, such as yearly amounts of public rural credits, number of fines, number of cattle, or share of farms without a title per municipality (also see Annex B, Table 36).

Table 30. Summary statistics on regression variables

\begin{tabular}{|c|c|c|c|c|c|c|}
\hline & $\mathbf{N}$ & Mean & SD & Min. & Max. & Units \\
\hline \multicolumn{7}{|c|}{ Time variant variables } \\
\hline \multicolumn{7}{|c|}{ Outcome variable } \\
\hline $\begin{array}{l}\text { Area deforested } \\
{\left[\mathrm{km}^{2}\right]}\end{array}$ & 5,230 & 22 million & 59 million & 0.00 & 1.2 billion & $\begin{array}{l}\text { Number of sq. km deforested } \\
\text { per municipality and year } \\
\text { (PRODES) }\end{array}$ \\
\hline \multicolumn{7}{|c|}{ Treatment variables } \\
\hline $\begin{array}{l}\text { Area officially } \\
\text { declared as strictly } \\
\text { protected } \\
\text { [share] }\end{array}$ & 5,230 & 0.031 & 0.093 & 0.00 & 0.551 & $\begin{array}{l}\text { Share of protected area } \\
\text { coverage calculated as the } \\
\text { cover of protected areas per } \\
\text { municipality and year (form } \\
\text { IBAMA) for the Brazilian } \\
\text { Amazon Legal }\end{array}$ \\
\hline
\end{tabular}




\begin{tabular}{|c|c|c|c|c|c|c|}
\hline & $\mathbf{N}$ & Mean & SD & Min. & Max. & Units \\
\hline $\begin{array}{l}\text { Area officially } \\
\text { declared as } \\
\text { multiple-use } \\
\text { protected area [as } \\
\text { a share of each } \\
\text { municipality] }\end{array}$ & 5,230 & 0.106 & 0.222 & 0.00 & 0.988 & $\begin{array}{l}\text { Share of sustainable use area } \\
\text { coverage calculated as the } \\
\text { cover of sustainable use area } \\
\text { per municipality and year (from } \\
\text { IBAMA) for the Brazilian } \\
\text { Amazon Legal }\end{array}$ \\
\hline $\begin{array}{l}\text { Area officially } \\
\text { declared as } \\
\text { indigenous territory } \\
\text { [share a share of } \\
\text { each municipality] }\end{array}$ & 5,230 & 0.082 & 0.168 & 0.00 & 0.980 & $\begin{array}{l}\text { Share of indigenous area } \\
\text { coverage calculated as the } \\
\text { cover of protected areas per } \\
\text { municipality and year (from } \\
\text { IBAMA) for the Brazilian } \\
\text { Amazon Legal }\end{array}$ \\
\hline $\begin{array}{l}\text { Field-based law } \\
\text { enforcement } \\
\text { inspections } \\
\text { [number of fines } \\
\text { imposed per year } \\
\text { for each } \\
\text { municipality] }\end{array}$ & 5,230 & 14.176 & 27.990 & 0.00 & 351 & $\begin{array}{l}\text { Number of fines imposed by } \\
\text { IBAMA law enforcement } \\
\text { missions (IBAMA for 2001- } \\
\text { 2010) }\end{array}$ \\
\hline $\begin{array}{l}\text { Municipalities that } \\
\text { have been publicly } \\
\text { blacklisted as } \\
\text { offenders against } \\
\text { the forest code } \\
\text { [number of } \\
\text { blacklisted } \\
\text { municipalities] }\end{array}$ & 5,230 & .0386 & .193 & 0.00 & 1.00 & $\begin{array}{l}\text { Number of blacklisted } \\
\text { municipalities per year (for } \\
\text { 2008-2012) }\end{array}$ \\
\hline $\begin{array}{l}\text { Access restriction } \\
\text { to rural credits } \\
\text { [Mio. Reais] }\end{array}$ & 5,230 & 11 & 25 & 0.00 & 423 & $\begin{array}{l}\text { Total amount of official rural } \\
\text { credits per year and } \\
\text { municipality (for 2008-2012) }\end{array}$ \\
\hline $\begin{array}{l}\text { Rural } \\
\text { environmental } \\
\text { registry }(\mathrm{CAR}) \\
\text { Billion }\left[\mathrm{km}^{2}\right]\end{array}$ & 5,230 & 0.269 & 1 & 0.00 & 240 & $\begin{array}{l}\text { Billion } \mathrm{km}^{2} \text { of rural area } \\
\text { registered under CAR }\end{array}$ \\
\hline $\begin{array}{l}\text { Soy Moratorium as } \\
\text { measured by } \\
\text { soy-suitable area } \\
\text { per municipality } \\
{[\%]}\end{array}$ & 5,230 & 0.853 & 0.354 & 0.00 & 1.00 & $\begin{array}{l}\text { Share of area suitable for soy } \\
\text { cultivation (for 2007-2012) }\end{array}$ \\
\hline
\end{tabular}

Source: Own table

Covariates and a data dictionary for our analysis can be found in Annex B, Table 36). 


\subsection{Results-The Marginal EfFect of Eight Environmental Policies ON DEFORESTATION IS SMALL}

\subsubsection{Fixed Effects Regression Results}

Using a fixed effects model, we estimate the annual area deforested per municipality in the Brazilian Legal Amazon due to the marginal effect of the eight environmental policies (see Table 31, left column). The fixed effects model captures the variance of deforestation within each municipality and circumvents the problem of unobserved time invariant factors. We expect the sign of the coefficients for seven of the eight environmental policies to be negative if deforestation declined (all coefficients are expected to be negative, except the one for credit. For rural credits, we expect the yearly amount of rural credits to go up with the decrease in deforestation).

According to our fixed effects model, both strictly protected areas and sustainable use areas are highly significant, but both seem to increase deforestation rather than contributing to its decline. With respect to strictly protected areas, a one unit increase in strictly protected areas is associated with a 0.86 unit increase in deforestation. A one unit increase in sustainable use areas can be associated with a 1.09 unit increase in deforestation. This result is surprising and is not in line with earlier findings from the literature (Soares-Filho et al. 2010, Nelson and Chomitz 2011, and Nolte et al. 2013).

Soares-Filho et al. (2010) use an adjusted odds ratio of deforestation to estimate the local effect of protected areas by comparing the mean adjusted odds ratio before and after designation as protected area using pairwise comparisons. They find that the deforestation inhibiting effect of strictly protected areas was 0.38 and the one of sustainable use areas was 0.33 . Both were much higher than in our fixed effects model.

Using forest fires as a proxy for deforestation, Nelson and Chomitz (2011, p. 4) find that "in Latin America and the Caribbean, multi-use protected areas appear to be as effective or more effective than strictly protected areas, but indigenous areas are almost twice as effective as any other form of protection." According to their model, mean reduction due to strict protected areas amounted to between 2.7 and 4.3 percentage points, whereas mean reduction in sustainable use areas amounted to between 4.8 and 6.4 percentage points.

Similarly, Nolte et al. (2013, p. 2) find that for protected areas established before 2000 "sustainable use areas were estimated to have avoided more aggregate deforestation than 
strictly protected areas." Corresponding coefficients amounted to 0.91 for sustainable use areas and to 0.39 for strictly protected areas, according to their model. All three authors found a considerable inhibiting effect of strictly protected and sustainable use areas.

A possible explanation for our surprising result is that Brazil has changed its policy for protected areas recently, prioritizing areas for protection that have already been threatened by deforestation. In earlier years, protected areas were established far away from the deforestation belt in locations that would not have been deforested in any case. Since the change in policy, protected areas are now being established in high-pressure zones, which our results might be picking up. Our results for strictly protected areas and sustainable use areas may thus represent a selection bias that shows up in our fixed effects model examining levels and not in our first difference model that compares deforested areas at two points in time from one year to the next.

In terms of indigenous areas, a one unit increase in indigenous areas is associated with a -0.864 unit decline in deforestation, according to the fixed effects model. This outcome is in line with results from the literature where indigenous territories tend to be the most effective in reducing deforestation (Nelson and Chomitz 2011, Nolte et al. 2013).

According to Nelson and Chomitz (2011, p. 7), "indigenous areas are shown to reduce forest fire incidence by 16.3-16.5 percentage points, over two and a half times as much as the crude estimates (5.9 percent) and twice as effective as any other group in the matched results, with a greater estimated avoided fire-affected area than strict, multiuse, and unknown combined." According to Nolte et al. (2013, p. 4), "Indigenous lands appeared particularly effective at curbing high deforestation pressure, relative to both strictly protected and sustainable use areas." Both findings confirm our estimates. 
Table 31. First difference and fixed effects model results assessing the marginal effect of eight environmental policies on deforestation

\begin{tabular}{|c|c|c|}
\hline VARIABLES & $\begin{array}{l}\text { Least } \\
\text { squares } \\
\text { fixed } \\
\text { effects } \\
\text { Model } \\
\end{array}$ & $\begin{array}{l}\text { Least-squares } \\
\text { first difference }\end{array}$ \\
\hline Cloud error (lagged) & $\begin{array}{l}-0.774 * * \\
(0.325)\end{array}$ & $\begin{array}{l}-1.487 * * * \\
(0.393)\end{array}$ \\
\hline Cloud error & $\begin{array}{l}-0.284 \\
(0.239)\end{array}$ & $\begin{array}{l}-1.510^{* * * *} \\
(0.223)\end{array}$ \\
\hline Annual mean temperature & $\begin{array}{l}-0.210 \\
(0.138)\end{array}$ & $\begin{array}{l}0.029 \\
(0.108)\end{array}$ \\
\hline Annual mean precipitation & $\begin{array}{l}0.002 \\
(0.001)\end{array}$ & $\begin{array}{l}0.002^{*} \\
(0.001)\end{array}$ \\
\hline Settlement area (logged and lagged) & $\begin{array}{l}0.012 \\
(0.010)\end{array}$ & $\begin{array}{l}-0.007 \\
(0.009)\end{array}$ \\
\hline Land price for forest area (logged and lagged) & $\begin{array}{l}0.398^{* * *} \\
(0.126)\end{array}$ & $\begin{array}{l}0.299 * * \\
(0.137)\end{array}$ \\
\hline Soy price (logged and lagged) & $\begin{array}{l}0.553^{* *} * \\
(0.236)\end{array}$ & $\begin{array}{l}-0.197 \\
(0.177)\end{array}$ \\
\hline Timber price (logged and lagged) & $\begin{array}{l}0.070^{*} \\
(0.038)\end{array}$ & $\begin{array}{l}-0.047 * \\
(0.025)\end{array}$ \\
\hline Number of cattle (logged and lagged) & $\begin{array}{l}0.252^{* * *} \\
(0.122)\end{array}$ & $\begin{array}{l}-0.168 \\
(0.160)\end{array}$ \\
\hline Per capita GDP from agriculture (logged and lagged) & $\begin{array}{l}0.074 \\
(0.165)\end{array}$ & $\begin{array}{l}0.015 \\
(0.120)\end{array}$ \\
\hline Per capita GDP (logged and lagged) & $\begin{array}{l}0.197 \\
(0.192)\end{array}$ & $\begin{array}{l}-0.042 \\
(0.180)\end{array}$ \\
\hline Distance to Brasília (logged) & & $\begin{array}{l}-0.124 * * \\
(0.059)\end{array}$ \\
\hline Share of area covered by forest in 2002 & & $\begin{array}{l}0.500 * * * \\
(0.064)\end{array}$ \\
\hline Population density in 2000 & & $\begin{array}{l}0.000 \\
(0.000)\end{array}$ \\
\hline Share of farms without a land title by year & & $\begin{array}{c}0.218^{* * *} \\
(0.085)\end{array}$ \\
\hline Indigenous territory (lagged by one year) & $\begin{array}{l}-0.864 \\
(1.397)\end{array}$ & $\begin{array}{l}-0.086 \\
(0.256)\end{array}$ \\
\hline Strictly protected area (lagged by one year) & $\begin{array}{l}1.754 * * * \\
(0.621)\end{array}$ & $\begin{array}{l}-1.413 * * * \\
(0.508)\end{array}$ \\
\hline Sustainable use area (lagged by one year) & $\begin{array}{l}1.087^{* * *} * \\
(0.396)\end{array}$ & $\begin{array}{l}0.193 \\
(0.433)\end{array}$ \\
\hline $\begin{array}{l}\text { Number of fines by IBAMA interacted with forest cover in } 2002 \text { (lagged } \\
\text { and logged) }\end{array}$ & $\begin{array}{l}0.148 \\
(1.186)\end{array}$ & $\begin{array}{l}-1.128 * * \\
(0.551)\end{array}$ \\
\hline Dummy of blacklisted municipalities & $\begin{array}{l}-1.079 \\
(2.159)\end{array}$ & $\begin{array}{l}-4.811 * * \\
(1.958)\end{array}$ \\
\hline $\begin{array}{l}\text { Dummy of blacklisted municipalities interacted with the area registered } \\
\text { under the CAR system (lagged and logged) }\end{array}$ & $\begin{array}{l}0.029 * * \\
(0.013)\end{array}$ & $\begin{array}{l}0.012 \\
(0.012)\end{array}$ \\
\hline $\begin{array}{l}\text { Dummy of blacklisted municipalities interacted with amount of rural credits } \\
\text { (lagged and logged) }\end{array}$ & $\begin{array}{l}-3.246 \\
(8.653)\end{array}$ & $\begin{array}{l}-6.001 \\
(5.349)\end{array}$ \\
\hline $\begin{array}{l}\text { Dummy of blacklisted municipalities interacted with number of fines by } \\
\text { IBAMA interacted with forest cover in } 2002 \text { (lagged and logged) and } \\
\text { interacted with blacklisted municipalities }\end{array}$ & $\begin{array}{l}0.057 \\
(0.123)\end{array}$ & $\begin{array}{l}0.252 * * \\
(0.119)\end{array}$ \\
\hline Area registered under the CAR system (lagged and logged) & $\begin{array}{l}-0.044 * * * \\
(0.008)\end{array}$ & $\begin{array}{l}-0.006 \\
(0.008)\end{array}$ \\
\hline Yearly amount of rural credits (lagged and logged) & $0.221 *$ & 0.171 \\
\hline
\end{tabular}




\begin{tabular}{|c|c|c|}
\hline & $\begin{array}{l}\text { Least } \\
\text { squares } \\
\text { fixed } \\
\text { effects } \\
\text { Model }\end{array}$ & $\begin{array}{l}\text { Least-squares } \\
\text { first difference }\end{array}$ \\
\hline VARIABLES & $(0.125)$ & $(0.162)$ \\
\hline Amazon biome interacted with the total number of rural credits (lagged and & -0.203 & -0.171 \\
\hline logged) & $(0.125)$ & $(0.162)$ \\
\hline Year 2008 interacted with the Amazon biome and the total number of rural & $-0.032 *$ & -0.010 \\
\hline credits (lagged and logged) & $(0.017)$ & $(0.010)$ \\
\hline Year 2007 interacted with the Amazon biome and the area suitable for soy & $-0.026 * * *$ & -0.003 \\
\hline & & \\
\hline Number of observations & 5,230 & 4,707 \\
\hline R-squared & 0.211 & 0.087 \\
\hline Adj. R2 & 0.117 & 0.080 \\
\hline
\end{tabular}

Robust standard errors in parentheses

$* * * \mathrm{p}<0.01, * * \mathrm{p}<0.05, * \mathrm{p}<0.1$

In terms of enforcement policies, a one unit increase in IBAMA fines can be associated with a non-significant 0.148 unit increase in deforestation. Here we interacted our policy variable 'IBAMA fines' with an indicator of baseline forest cover in 2002 (lagged and logged). Similarly, a one unit increase in blacklisting can be associated with a non-significant -1.079 unit decline in deforestation. Interacting the blacklisting policy variable with the area registered under the CAR system (lagged and logged) we find that a one unit increase the interaction term can be associated with significant $0.029 * *$ unit increase in deforestation.

We also moderated the effect of IBAMA fines with a triple interaction between the number of fines by IBAMA interacted with forest cover baseline in 2002 (lagged and logged) and interacted with blacklisted municipalities. Given the likely spatial overlap between blacklisted municipalities and IBAMA fines, we find that a one unit increase in the interaction term can be associated with a non-significant -3.246 unit decrease in deforestation.

Similarly, for the interaction between blacklisted municipalities and the amount of rural credits, a one unit increase in the interaction term can be associated with a non-significant 0.057 unit decrease in deforestation. The coefficient for blacklisted municipalities increases with the interaction with IBAMA fines, normalized by baseline forest cover levels and becomes smaller with the interaction of rural credits. It changes the sign and becomes significant with the interaction with the area registered under the CAR system, demonstrating an increase in the association with deforestation. 
Both IBAMA fines and blacklisting are non-significant in the fixed effects model and the fines become positive, meaning that the policy tended to contribute to deforestation rather than reducing it, according to this model. Neither result corresponds to our expectations based on the literature. As explained in chapter four (Table 27) for IBAMA fines, Börner et al. (2015) and Hargrave et al. (2013) have demonstrated convincingly that fines do reduce deforestation to some extent and the same is true for blacklisting, as demonstrated by Cisneros et al. (2015). The results are not significant in the fixed effects model, but will correspond to our expectations in the first difference model, where they become significant and negative.

The last three policies are significant in the fixed effects model. According to the fixed effects model, a one unit increase in the registered number of rural properties in the rural cadaster system is associated with a $-0.04 * *$ unit decline in deforestation and a one unit increase in soysuitable area in the Amazon biome is associated with a $-0.03 * * *$ unit decline in deforestation. To measure the soy moratorium, we used a triple interaction. We modified our variable 'soysuitable area' by restricting it to the Amazon biome only, to which it applies and interacted it with the year 2007 by which time the policy came into effect.

Lastly, a one unit increase in the amount of rural credits is associated with a significant $0.22 *$ unit increase in deforestation. However, if we interact the amount of rural credits with the year 2008 in which the rural credit restriction policy became effective and with the Amazon biome to which the policy applies, we see that a one unit increase in the amount of rural credits can be associated with a significant $-0.032 *$ decline in deforestation, meaning the rural credit restriction policy contributed to the decline in deforestation.

Here the fixed effects model shows a small marginal and significant effect of these three policies on deforestation. Interestingly, other authors did not find an effect for the rural cadaster system and the rural credit restriction policies on deforestation (Rajão et al. 2012 and Gibbs et al. 2015). For example, Rajão et al. (2012), who use a control group to compare deforestation on registered and non-registered properties, find that "during the first 8 years [the rural cadaster system] had no significant impact on reducing deforestation" (p. 229).

One caveat with using a fixed effects model is that standard errors are large, especially if, according to Allison (2009, p. 9): “the predictor variable has little variation over time.” In our model, policies tend to show a large one-time change when a new policy is introduced, but 
smaller changes the following years. Our standard errors for our fixed effects model are relatively large.

In the next paragraph, we will compare results from our fixed effects model with our first difference model that captures one-time changes, but not the sustained change in the policy over the 10 -year period.

\subsubsection{First Difference Regression Results}

According to our first difference model (Table 31 right column), we find that a one unit increase in strictly protected areas can be associated with a large and highly significant $-1.413 * * *$ unit decline in deforestation. By comparison, a one unit increase in indigenous areas can be associated with a -0.86 unit decline in deforestation, and a one unit increase in sustainable use areas can be associated with a -0.19 unit decline in deforestation, although not significant.

With respect to IBAMA fines and blacklisting, a one unit increase in the number of IBAMA fines can be associated with a significant $-1.13^{* *}$ unit decrease in deforestation and a one unit increase in the number of blacklisted municipalities can be associated with a $-4.8^{* *}$ unit decrease in deforestation, both significant at the 10 percent level.

Both variables have been interacted as explained under the fixed effects regression results. These first difference results as well are more in line with the literature and our expectations given the declining trend of deforestation in the Brazilian Amazon. As for the triple interaction between IBAMA fines, forest cover baseline in 2002, and blacklisted municipalities, the coefficient increases, but becomes non-significant. While the interaction between blacklisting and the area registered under the CAR system, lowers the coefficient and makes it positive, meaning an increase in deforestation, the interaction with yearly amount of rural credits lowers the coefficient while still keeping it significant at the 10 percent level.

Finally, the three remaining policies were not significant in the first difference model. According to the first difference model, a one unit increase in the number of properties registered under the rural cadaster system can be associated with a -0.006 unit decrease in deforestation. Similarly, a one unit increase in area suitable for soy plantation within the Amazon biome to which the Soy Moratorium applies, can be associated with a -0.003 unit decline in deforestation. Lastly, a one unit increase in the amount of rural credits issued can be 
associated with a 0.17 unit increase in deforestation. However, if we interact the amount of rural credits with the year 2008 in which the rural credit restriction policy became effective and with the Amazon biome, to which it applies, a one unit increase in rural credits can be associated with a -0.01 unit decline in deforestation, indicating that the rural credit policy can be somewhat associated with curbing deforestation. These results correspond to our expectations as they show a declining trend of deforestation, even though they are not significant.

The first difference model matches much more closely our expectations from the literature, suggesting that the unobserved time variant effects may play a role in modeling deforestation and that there may be serial correlation between the error term and the policy variables, something future research will examine more closely.

While the fixed effects model had an adjusted $\mathrm{R}^{2}$ of 0.12 , the first difference model had an adjusted $\mathrm{R}^{2}$ of 0.08 , meaning that only a small part of the variation in the area deforested can be explained by the model. This means that the policies do not explain much of the variation in the model, but that it is the fixed effects and time effects that we do not see in the model that are responsible for the variation. We can extract those fixed effects and time effects from the model as gaps. Therefore, it is all the factors that cannot be explained that vary between states and over time that explain the large variation in the dependent variable of deforestation. This also means that the decline in deforestation depends on the local context, an important finding that we will discuss further below. This also means that a lot more is happening in the decline in deforestation that models predicting deforestation cannot yet capture. This is an important lesson of the analysis. Therefore, more research is needed to better explain what factors can be associated with the decline in deforestation over space and time (see Annex B, Table 37 and Table 38).

Deciding whether the fixed effects or first difference model is more efficient to answer our research question is difficult. According to Adre $\beta$ et al. (2013, p. 190), "it is difficult to choose between both estimators on statistical grounds." The efficiency for both methods depends on serial correlation of the idiosyncratic errors (Adre $\beta$ et al. 2013, p. 190). "If $e_{\text {it }}$ is uncorrelated, $\mathrm{FE}$ is more efficient than FE; if $\Delta e_{\text {it }}$ is uncorrelated, FD is more efficient that FE" (Adre $\beta$ et al. 2013, p. 190). Furthermore, "for research questions related to instantaneous change of Y, FD seems to be the most adequate method, while for research questions related to the level of Y, FE seems to be more useful" (Adre $\beta$ et al. 2013, p. 190). 
At first glance, given that we expect endogeneity in our deforestation model, the fixed effects model would be more efficient to answer our research question. However, given that some of the policies introduced in later years, such as blacklisting, rural credit restrictions, the rural property registration system, and the Soy Moratorium show dramatic one-time changes from one year to the next, the first difference model may be more efficient to answer our research question.

In addition, Principal Component Analysis discussed under methods showed that the later policies, such as blacklisting, rural credit restrictions, rural environmental registry, and the Soy Moratorium provided the bulk of the information in the system. This is another reason why using the first difference model may be more efficient.

\subsection{Discussion And Conclusions-Local ConteXt Matters}

This chapter combined eight environmental policies in Brazil to model various policy drivers of land cover change in the Brazilian Amazon.

We used fixed effect and first difference models to see whether environmental policies can be associated with a decrease in deforestation in the Brazilian Amazon. The literature on spatially explicit models of deforestation suggests that endogeneity between our municipality fixed effects and some of the known explanatory variables may be important. We therefore used a fixed effects model (more robust against threats of endogeneity), to model environmental policies as potential drivers of the decline in deforestation.

Our results show that the marginal effect of the strictly protected areas, sustainable use areas, and IBAMA fines are associated with an increase in deforestation relative to the other policies, according of these fixed effects model, something we explain by a recent shift in policy toward areas that are already threatened by deforestation. The policies with the largest marginal effect, according to the fixed effects model, were the rural land registry ( -0.44 percentage points) and the Soy Moratorium (-0.026 percentage points), both highly significant, as well as access to rural credit restrictions, indigenous territories, and blacklisting.

While we would expect the fixed effects model to be more efficient at modeling the decline in deforestation given the robustness to endogeneity threats, some of the policies seemed to be associated with an increase in deforestation rather than a decline. We therefore concluded that looking at levels (fixed effects model) may not be the best way to model the decline in 
deforestation and therefore also used a first difference model that takes the time dimension and changes from one year to the next into account.

The first difference model correctly captured the declining trend in deforestation, associated with the environmental policies. In this model, strictly protected areas were highly significant and contributed to the decline in deforestation. The largest marginal effect according to the first difference model came from blacklisting of municipalities, followed by strictly protected areas, and IBAMA fines. The first difference model proved more effective at modeling the general trend in the decline in deforestation (all expected variables were negative, i.e., modeled the decrease in deforestation area) compared with the fixed effects model. However, both models explained only a small fraction of the decline in deforestation and showed that the local context is important, but not captured by the models.

The important point here is that the econometric models point to local context factors that vary across states and time as important explanatory factors in the dramatic decline in deforestation. We find that the declining deforestation is less dependent on the choice of the policy instrument, but more on the context in which the policy is being implemented. As Börner et al. (2016) recommend based on a review of different econometric models modeling deforestation: "A host of factors including pre-program levels of compliance with intervention goals, policy design, and quality of implementation co-determine outcomes - potentially as strongly as the proper policy instrument choice" (p. 8). Thus, the political economy, such as availability of resource and the political will may be important factors that determine the way a policy instrument is being implemented.

Even though the effect size is small with respect to the variation in the model, the policies can be associated with, there is still some variation among them. This variation is not a measure for the true estimate of the policy impact on deforestation, but just a relative estimate in comparison to the other policies and their marginal effect of overlapping policies on the ground. In addition, the model encounters location bias and sampling, or selection bias. Some areas were more remote and not threatened by deforestation. In those cases, the impact estimates are small, as in the case of sustainable use areas or strictly protected areas.

Other policies are deliberately targeting some areas that are under high pressure, such as strictly protected areas, IBAMA fines, and blacklisting. Here we expect to see larger impacts, which we do. Given the selection and location biases, this result confirms my earlier finding that the 
marginal effect of environmental policies on the decline in deforestation is highly dependent on context and that there is a gap in our knowledge regarding what explains the dramatic decline in deforestation in Brazil. Before I conducted this research, I did not know that there was this gap. However, more research is needed to better explain the decline in deforestation in the Brazilian Amazon.

My contribution to the literature is that I modeled the marginal effect of eight environmental policies as drivers of deforestation. Other authors have modeled economic factors and policy factors in general using a proxy, but no other author has looked at the marginal effect of the policy mix of different environmental policies that overlap on the ground. I found that even though there are many known factors that can be associated with deforestation and forest preservation, the larger part is still unknown. Our model explained just a small fraction in the decline and indicates high variation in the unobservable municipality and time fixed effects.

Therefore, more research is needed to better understand how the different policies interact. For example, further research could estimate each policy's relative contribution to deforestation by artificially setting the effect of a single policy to zero and thus estimating the change and contribution of this policy to the decline in deforestation. In addition, further research could elaborate the models' spatial aspects, as well as higher resolution of deforestation data. A planned paper will elaborate on these aspects. 


\section{THE WAY AHEAD IN UNDERSTANDING THE SUDDEN DECLINE IN DEFORESTATION}

\subsection{Conclusions \& Discussion}

The objective of this chapter is to determine the extent to which I was able to answer the overarching research question and the four sub-questions. I also reflect on the strengths and weaknesses of this research and determine the contribution of my research to the existing literature. Finally, I determine further steps to extend the research, as well as what remains to be done.

In the beginning of this book, I presented the reader with the stunning and dramatic decline in deforestation in the Brazilian Amazon since 2004 (Figure 4). The objective of this research was to better understand why deforestation declined so fast.

The reserach findings indicate that the rapid decline in deforestation can be explained not only by economic factors, as described in the existing literature, but also by a mix of environmental policies issued and enforced by the Brazilian government. Protected areas have played a role in the decline, as have enforcement policies, such as IBAMA fines, public disclosure, and rural credit restriction. The use of satellite data to monitor deforestation has likely contributed to the decline in deforestation as well.

Other factors discovered during my research are tied to increased awareness in Brazilian society about the environment and the looming threats of climate change. Another unexpected factor that seems important is declining population growth among the non-indigenous population and urbanization in line with a possible decline in agricultural production. More research is needed on this issue. In addition, the literature makes commodity prices responsible for part of the decline and there are several location-specific factors where the answers are not yet known, as I explained in chapter five.

The problem here is that impact evaluation methodology provides a narrow and precise estimate of what works and what does not in a specific context. However, it tends not to make this context explicit. My research has encountered the same problem in providing a precise estimate of the effect of different environmental policies, without clearly analyzing the context and what factors made the policies effective. More research on the specific context under which 
a policy will have an effect is needed and researchers need to adjust research methods and theoretical models accordingly, as explained further in the next section.

\subsubsection{Implications of the Research for Theory Building}

This research discussed the von Thünen and the forest transition theories, which help conceptualize the way forest resources are being used. The theories highlight economic and policy factors that can be associated with deforestation, such as agricultural use of formerly forested land, commodity prices, the number of people living in rural areas as opposed to urban, and environmental policies.In this dissertation, I observed how the implications of the von Thünen theory can change landscapes over time. The field visit to four indigenous communities led me to conclude that indigenous communities made sedentary due to land titling and demarcation of their territories create small market centers with small agricultural zones scattered around their villages. These centers become stronger with a river and much more so with a road going through the village and connecting the smaller marketplace to a bigger market center. Thus, even forest areas in the outer concentric circle may see many more small market centers (see Figure 10). Within the stylized concentric circles of the von Thünen theory, new centers and circles may emerge.

The creation of a multitude of small market centers in rural areas in the middle of the Amazon is not only supported by demarcation, but also by pension payments, by Bolsa Familia conditional cash transfers, and the opening of schools and health clinics. Brazil seems to follow the pattern of many developed countries in which rural areas are becoming suburban, although they are located far away from urban centers. Indigenous territories have not yet reached health indicators and literacy levels comparable with urban areas, but indigenous peoples' lives, even though dependent on traditional livelihoods seemed modern and in line with urban areas, something that was also supported by frequent migration and a life in between rural and urban areas.

The second theory, forest transition theory, seeks to explain how the extent of forested areas varies, depending on how many people live in rural areas and depend on agriculture for their livelihood. With population growth, forested areas decline and with economic development and rural-urban migration, fallow agricultural land returns to forested land. This development path was noticeable among the indigenous communities in the Brazilian Amazon.

Environmental policies create incentives to reduce deforestation. However, policies tend not to play out entirely the way they have been designed. In most cases, policies are less effective 
than their models predict. The Brazilian Amazon is especially interesting, given that policies seemed to have had an effect that matched expectations, at least between 2004 and 2012. In other regions of the world, policies often exist on paper only.

In this dissertation, I tried to capture the extent to which environmental policies in the Brazilian Amazon are associated with the sudden decline in deforestation between 2004 and 2012. In chapter four, I compared the effect size of different papers. I found that the effect of forest preservation is less the result of the choice of instrument (the policy), but more of the context in which the policy has been implemented. In the context of the Brazilian Amazon, effect sizes turned out to be quite similar for different policies, for example.

Börner et al. (2016, p. 8) come to a similar conclusion by analyzing PES when they find: "A host of factors including pre-program levels of compliance with intervention goals, policy design, and quality of implementation codetermine outcomes - potentially as strongly as the proper policy instrument choice. High environmental threats increase the scope for effective counteraction. Careful documentation of context factors and intervention design elements is thus paramount to making sense of comparative analyses within and across policy categories." Even though context factors have been included in earlier models based on the von Thünen theory, they have not yet sufficiently been taken on board by the more recent wave of quantitative studies using spatially explicit models and impact evaluation methods.

In the future, the economic theory of deforestation needs to be developed further. Deforestation theory and models tend to assume that policy instruments will be effective. They need to consider that policy instruments may not be playing out as intended on the ground due to local factors. We therefore need an economic policy perspective that goes beyond impact evaluation methodology and tries to explain why certain policies are playing out the way they are in a specific context.

Among the reasons policies are not as effective as designed is either that funds are lacking for implementation, or there is no political will, or there is no interest, and no one wants to implement the policies in the first place. A research cycle tends to start with a theory, build a hypothesis, test the hypothesis, and come to conclusions, which should be fed back into the theory. This last step is often missing from the research process. Given that policies rarely work as designed, we need to improve our theory and models to adjust them better to the reality on the ground. 
In my dissertation, for example, I tested whether there is a difference in terms of forest preservation between demarcated and non-demarcated indigenous territories. I used geospatial impact evaluation methods. There is no statistically significant effect between demarcated and non-demarcated indigenous territories, because most indigenous territories are too remote and distant from the deforestation frontier to show an effect. At the same time, visiting the area and observing how demarcation plays out on the ground and affects the lives of the indigenous communities helped me understand that demarcation had a positive effect on the livelihoods and survival of the indigenous communities and that they are interested in preserving the forest because their livelihoods depend on it.

In terms of theory building, enforcement is an important piece of the puzzle for forest preservation in indigenous and non-indigenous areas. Enforcement considerations have been part of the design of the Indigenous Lands Project, but according to the design, the weakest segment of society was supposed to do the most difficult job, which is preserving natural forest resources from wild west-style rent-seeking interests. Brazil's enforcement policy, led by IBAMA, supported the indigenous communities from 2004 onwards, something that needs to be taken on board as good practice in future projects.

Following forest transition theory, we analyzed in chapter five to what extent environmental policies in the Brazilian Amazon can be associated with the decline in deforestation. We looked at the marginal effect that eight different environmental policies had on the decline in deforestation. As in the case of the Indigenous Lands Project where forest preservation in indigenous territories depended on the IBAMA forest police for enforcement and the preservation of borders, the effect of one policy depends on other policies in the Brazilian Amazon. This also means that the combined effect of the policies is different from the sum of partial effects.

Structural Equation Modeling (SEM) allows the researcher to analyze policy interaction effects, and to critically evaluate the results from other studies. SEM helps to determine causal pathways for different context-specific samples. When using SEM, we estimate a model according to the way we think it plays out on the ground.

In the context of deforestation in the Brazilian Amazon, using SEM proved difficult because of endogeneity. I would have needed a host of data that do not exist. I therefore used reduced form estimates. As researchers we know that the slowdown in deforestation is a function of 
many factors, represented by our variables. We do not know exactly what the function would look like and therefore we estimate a linear equation model. This is what I did in chapter five.

Ideally, I would have set up an SEM model that captures policy influence on the decline in deforestation in the Brazilian Amazon. Following the von Thünen theory, I would have modeled deforestation as a function of demand for land. I would have modeled forest as input, or demand (such as labor, capital, and land), in the production process. Then, I would have modeled output, or supply (such as agricultural products).

I would have had to estimate two equations, (1) and output-supply equation and (2) and inputdemand equation to be estimated simultaneously. But this creates a host of endogeneity problems. The theory that unites the various factors that influence the decline in deforestation cannot be modeled. To model the theory, I needed additional data that are almost impossible to find, such as costs of agricultural inputs. Estimating an SEM model would have required to model a representative farmer, but this would have made the results much less interesting because of the host of assumptions needed for the model.

Nelson et al. (2011) showed that ideally one would estimate deforestation as a sub-model using SEM. However, because the data required are not available, they decided to use a reduced form estimate; and thus, other researchers, including myself, have followed their lead. Therefore, researchers tend to estimate deforestation models in reduced form models, modeling deforestation as a function of different variables.

\subsubsection{Summary, Contribution to the Literature, Caveats, and Next Steps for Research Question 4}

I identified a gap in the literature with respect to the marginal effect of environmental policies on deforestation. While other authors have examined individual policies and their effect on deforestation, no other paper has combined eight different environmental policies in a model that predicts deforestation outcomes. Other authors claimed that environmental policies play a major role in the decline in deforestation. Assunção et al. (2015), for example, created a model that predicts deforestation well until 2004, but not so well after 2004. Since the policy changed in 2004, they attribute the difference between their model and the decline in deforestation outcomes to the changes in policy. 
Similarly, we find that all the things we cannot measure precisely explain an important part of the decline in deforestation. These factors include macro-scale policy effects that our treatment indicators are not picking up. This also means that we cannot ignore policies in econometric models of deforestation anymore, which is an important statement given that most previous models tend to not include policy variables.

This finding is a step in the direction of understanding the sudden decline in deforestation. Our research includes more detailed variables that model environmental policies than, for example, Assunção et al. 2015, who include land scarcity as a proxy for the effect of environmental policies on deforestation. It thus contributes to the existing literature. However, the fact that our model only explains a small part of the variation in deforestation between the municipalities in the Brazilian Amazon shows that the research community is only beginning to understand the marginal effects of environmental policies. It is all the factors that cannot be explained that vary between states and over time that explain the large variation in the dependent variable of deforestation. More work is therefore required.

A further step in this research is to take geospatial auto-correlation into account. The required analysis for this research has already been done and the research team will take this forward and publish the resultant article in an appropriate journal.

Based on our research I can answer my research question 4, "How much of the decline in deforestation in the Brazilian Amazon between 2003 and 2012 can be explained by eight different environmental policies?" My research shows environmental policies do indeed play a role in the decline in deforestation, but that the marginal effect of policies is highly specific to context.

When I look at my overarching research question, I see that more research is needed to understand the decline in deforestation. I also notice that my modeling approach only brings me so far. Either we need to devise much different ways to model deforestation and environmental policies, or we need to drill down to the local level and gain a qualitative understanding of why deforestation decreased in specific locations. Verifying global models with concrete experience could help us gain a better understanding of the deforestation decline. Combining qualitative and quantitative methods has the potential to solve some of the riddles that one method cannot solve. I demonstrated this approach for the Indigenous Lands Project (research question 1 and 2) in this book. 


\subsubsection{Summary, Contribution to the Literature, Caveats, and Next Steps for Research Question 3}

The objective of research question 3 was to compare the results from other authors in the peerreviewed literature. I compared six articles that met my criterion of some form of statistical matching analysis. I wanted to understand how the effect size of five environmental policies compare with each other. My research question was: "How do environmental policies compare with each other in terms of their effect sizes?" I covered five and not eight policies in this chapter as the literature for the remaining three policies did not meet my rigorous selection criteria.

To answer this question, I relied on the methodology developed by Samii et al. 2014 making the effect sizes comparable. The six papers covered the following environmental policies: (1) strictly protected areas, (2) sustainable use areas, (3) indigenous territories, (4) enforcement missions, and (5) public disclosure. All these policies apply to the Brazilian Amazon region.

My research developed the theoretical pathways for each of the policies according to which they affect deforestation outcomes. Among the seven policies, the Soy Moratorium is an exception, because it is a supply-side mechanism that compels producers, traders, and international and national buyers to comply with Brazil's Forest Code and thus reduce deforestation.

The other policies are public sector policies that coerce people into compliance by restricting access to an area (protected areas), by allowing only sustainable use (sustainable use areas and indigenous territories), by some form of punishment, such as fine illegal felling and confiscating production equipment (enforcement missions), or by blacklisting municipalities with high deforestation rates and thus shaming them into compliance (public disclosure).

The results of this research show that the average effect size was relatively small and comparable for most of the five environmental policies. This means that environmental policies tend to have a relatively small annual effect on deforestation. In terms of my overall research question as to why deforestation declined dramatically after 2004, this research explains a relatively small, but steadily increasing part of the decline, given the assumption that the policies are being upheld.

This result is consistent with my findings on research questions 2 and 4. On the positive side, triangulation of results using different approaches as used in this research increases my 
confidence in the findings. On the negative side, I find that public policies to preserve forests are long-term investments and tend to show only small incremental effects from year to year if the policy is implemented and enforced.

Here as well, our finding is that context matters in terms of the effectiveness of different environmental policies. It even matters more than the policy instrument by itself (given that the effect sizes of different policies are comparable in size). My contribution to the literature on environmental policies (Samii et al. 2014 and Börner et al. 2016), is that the research community has more evidence about how environmental policies compare in terms of their effect sizes.

To expand this research, I would want to identify additional papers using statistical matching analysis from other countries within Latin America and on other continents, as well as on other environmental policies, to compare the effects of policies on forest protection.

In addition, further research is needed in refining models that predict deforestation and detect effects in deforestation and/or forest preservation.

\subsubsection{Summary, Contribution to the Literature, Caveats, and Next Steps for Research Question 2}

To gain a better understanding, I drilled down into one of the environmental policies regarding indigenous land rights. I selected the policy of preserving forests through declaring and demarcating indigenous territories, thereby providing indigenous peoples with the right to serve as stewards of forest preservation for future generations, something indigenous peoples consider part of their cultural heritage.

The peer-reviewed literature on forest preservation tends to compare indigenous lands with non-indigenous lands, or other protected area types, such as strictly protected areas, sustainable use areas, or military reserves. Another strain of literature presented in chapter one discusses land tenure and insecure property rights as an important driver of deforestation. We contribute to both strains of literatures with our research by examining whether demarcating indigenous territories by providing communities with the rights to their lands has made a difference for forest preservation. In this research we compared communities that had been demarcated with communities that were not demarcated to determine the effect. 
My second research question was: "What has been the effect of demarcating indigenous territories on forest preservation?" To answer this question, I used a long time series of satellitebased forest cover data as well as matched samples of treated and comparison communities. I found that there is no statistically significant effect of demarcating indigenous territories on forest preservation. The analysis does not show an effect because most of the indigenous communities demarcated under the Indigenous Lands Project are not yet threatened by deforestation. Thus, demarcating indigenous territories may be an investment for the future that does not yet show immediate results. The implication for my overall research question of why deforestation declined dramatically after 2004, I did not find an answer in this chapter. Therefore, more research is needed to understand the decline.

KfW Development Bank and AidData have already expanded the research. A follow-up paper expanded the original dataset to include all indigenous territories in the Brazilian Amazon and combined it with data on land disputes between indigenous communities and their neighbors. They found that demarcating indigenous territories reduces land disputes.

Based on this more complete data, my research could be extended. I would then be able to identify "high-pressure" communities where covariates indicate deforestation is expected to be greater and treatment effects potentially larger. This would enable us to test whether a greater sample and more precision in estimation would result in a larger treatment effect. This research would then inform policymakers about the importance of targeting scarce resources into areas of high pressure, something that has already been started in the Brazilian Amazon.

\subsubsection{Summary, Contribution to the Literature, Caveats, and Next Steps for Research Question 1}

The purpose of the research conducted to answer research question 1 was to drill down even further and field test local perceptions of four of the indigenous communities that were demarcated under the Indigenous Lands Project.

This research is based on a field visit to four such communities in the Brazilian state of Amazonas. It uses a qualitative case study methodology. The objective of the research was to acquire field experience and better understand the local living conditions and livelihoods of indigenous peoples living in demarcated indigenous territories. Research question 1 for this part of the dissertation was the following: "How does formalizing of land rights and monitoring 
support lead to improvements in indigenous peoples' livelihoods and survival in demarcated indigenous territories?"

In my research, I found that providing indigenous peoples with the rights to their lands not only improves their cultural autonomy but also supports their survival by creating livelihood opportunities. Even though a certain level of poverty persists in remote areas of indigenous territories, living conditions have improved dramatically over the past two decades. This means that indigenous territories at the time of my field visit had access to modern amenities, such as schools, health centers, electricity, and improved sources of water.

Answering my first research question fills an important gap in the literature in that it explores whether the population living in indigenous territories can survive and whether demarcation and monitoring support led to improvements in indigenous peoples' livelihoods. It refutes the counter-hypothesis that making indigenous peoples sedentary by providing them with a land title is a threat to the indigenous way of life and well-being. To my knowledge, literature on indigenous peoples in the Amazon is either ethnographic, covering specific tribes, focuses on indigenous peoples' rights to land and natural resources, their health status, or on migration patterns. My contribution to these bodies of literature is that I add the aspect of land demarcation, tenure rights, and livelihoods.

I used a qualitative research approach and triangulation in the absence of historic data on individual indigenous communities. The advantages of this qualitative research are that it enabled an on-the-ground perception and verification of how indigenous peoples perceive land demarcation and land rights and what the possible effects were on their survival and their livelihoods.

On the negative side, the qualitative research is based on four cases and perceptions that can be subjective and influenced by the researcher and the time of the research. Therefore, this case study research could be extended to other indigenous communities in the Brazilian Amazon. In addition, it would be interesting to look at the other social programs that were implemented in parallel with the Indigenous Lands Project.

\subsection{Contribution to the Literature And Policy Relevance}

This research filled a gap in that, for the first time, I compared demarcated with non-demarcated indigenous territories and thus assessed the effect of demarcation on forest preservation. I 
validated the findings through a field mission to four indigenous territories and assessed the effect of demarcation on community survival and well-being in terms of livelihood opportunities, education and health, and migration.

The second part filled an important research gap as well, as it compared the marginal effectiveness of environmental policies for the Brazilian Amazon. So far only individual policies or policy combinations have been assessed, but this research adds to the literature in that it compares the policies' marginal effectiveness using spatially explicit statistical modeling.

Assessing the effectiveness of environmental policies is relevant for Brazil and beyond as the world prepares to ramp up action for climate mitigation and adaptation in the follow-up to the Paris conference in 2015 and following conferences in Marrakesh 2016 and Bonn 2017. The Amazon is the world's largest rainforest, important for the global climate and the region's water resources and biodiversity. Determining the marginal effect of environmental policies provides policymakers with valuable information about what works and what does not.

Knowing how an environmental policy mix works in preserving forest resources will help in turning the Amazon forest back from a net emitter of greenhouse gas emissions into a net carbon sink. The large areas of indigenous territories in the Brazilian Amazon will, if maintained in the future, build an effective buffer against intruders, preserve the forest, and create livelihoods for indigenous peoples for generations to come.

Much of future forest and biodiversity preservation depends on the government of Brazil and its population, but the international community has also a vital role to play through international aid which creates incentives for policy changes.

In general, a better understanding of how environmental policies interact with each other in their spatial dimensions would help improve targeting, such as in indigenous communities, where those in high forest pressure zones tend to form a better buffer against deforestation. In particular, land demarcation, especially the demarcation of indigenous territories, as well as the voluntary environmental registry (CAR system) can be an important strategy of limiting open access and land grabbing in the Brazilian Amazon. 
Today, if Rousseau's well-known statement on land ownership does not appear overly innocent, it at least appears outdated. It is important to demarcate land and ensure land titling to preserve the land and forest resources for future generations. 


\section{REFERENCES}

Abadie, A., Diamond, A., and Hainmueller, J. 2015. "Comparative Politics and the Synthetic Control Method.” American Journal of Political Science. 59(2): 495-510. DOI: 10.1111/ajps.12116.

Aguiar, A.P.D., Câmara, G., and Escada, M.I.S. 2007. "Spatial statistical analysis of land-use determinants in the Brazilian Amazonia: Exploring intra-regional heterogeneity." Ecological Modelling 209(2-4): 169-188.

Alexiades, M.N. 2009. Mobility and migration in indigenous Amazonia: Contemporary ethnoecological perspectives - an introduction. In M.N. Alexiades, ed. Mobility and Migration in Contemporary Amazonia: Contemporary ethnoecological perspectives. New York: Berghahn Books, 1-46.

Alix-Garcia, J., Shapiro, E., and Sims, K. 2012. "Forest conservation and slippage: evidence from Mexico's National Payments for Ecosystem Services Program.” Land Economics 88, 613-638.

Allison, P.D. 2009. Quantitative Applications in the Social Sciences: Fixed effects regression models Thousand Oaks, CA: SAGE Publications Ltd doi: 10.4135/9781412993869.

Almeida, C.T., Oliveira-Júnior, J.F., Delgado, R.C., Cubo, P., and Ramos, M.C. 2017.

"Spatiotemporal rainfall and temperature trends throughout the Brazilian Legal Amazon, 19732013." International Journal of Climatology, 37: 2013-2026 (2017). Published online 20 July 2016 in Wiley Online Library (wileyonlinelibrary.com) DOI: 10.1002/joc.4831.

Alston L.J., Libecap, G.D., and Schneider, R. 1996. “The Determinants and Impacts of Property Rights: Land Titles on the Brazilian Frontier." Journal of Law, Economics and Organization, 12 (1): 25-61.

Andam, Kwaw S., Ferraro, P.J., Pfaff, A., Arturo Sanchez-Azofeifa, G., and Robalino, J.A. 2008. "Measuring the Effectiveness of Protected Area Networks in Reducing Deforestation." Proceedings of the National Academy of Sciences 105(42): 16089-16094.

Andersen, L., Granger, C., Reis, E.J., Weinhold, D., and Wunder, S. 2002. The Dynamics of Deforestation and Economic Growth in the Brazilian Amazon. Cambridge: Cambridge University Press.

Andrade de Sá, S., Palmer, C., and di Falco, S. 2013. "Dynamics of Indirect Land-Use Change: Empirical Evidence from Brazil." Journal of Environmental Economics and Management 65(3): 377-393. 
Andreß, H.-J., Golsch, K., and Schmidt-Catran, A. 2013. Applied Panel Data Analysis for Economic and Social Surveys. Berlin, Heidelberg: Springer. DOI: 10.1007/978-3-642-32914-2.

Andrews, M., Pritchett, L. and Woolcock, M. 2017. Building State Capability. Evidence, Analysis, Action. Oxford, U.K.

Angelsen Arild. 2010. Policies for reduced deforestation and their impact on agricultural production. Proceedings of the National Academy of Sciences Nov 2010, 107 (46) 19639-19644; DOI: 10.1073/pnas.0912014107.

Angelsen, A. and Kaimowitz, D. 1999. Rethinking the Causes of Deforestation: Lessons from Economic Models. The World Bank Research Observer, 14, 73-98. http://dx.doi.org/10.1093/wbro/14.1.73.

Angelsen, Arild. 2007. Forest Cover Change in Space and Time: Combining the von Thünen and Forest Transition Theories. Policy Research Working Paper; No. 4117. World Bank, Washington, DC. (C) World Bank. https://openknowledge.worldbank.org/handle/10986/7147 License: CC BY 3.0 IGO.

Angrist, J.D., and Pischke, J.-S. 2009. Mostly Harmless Econometrics. Princeton, NJ: Princeton University Press.

Araújo, C., Bonjean, C.A., Combes, J.L., Motel, P.C., and Reis, E.J. 2009. "Property rights and deforestation in the Brazilian Amazon.” Ecological Economics 68(8-9): 2461-2468. doi: 10.1016/j.ecolecon.2008.12.015.

Arguedas, J.M. 1957. Evolución de las comunidades indígenas.

Arguedas, J.M. 1958. El arte popular religioso y la cultura mestiza.

Arima, E.Y., Barreto, P., Araújo, E., and Soares-Filho, B. 2014. "Public policies can reduce tropical deforestation: Lessons and challenges from Brazil." Land Use Policy 41: 465-473.

Arima, E.Y., Richards, P., Walker, R., and Caldas, M.M. 2011. "Statistical confirmation of indirect land use change in the Brazilian Amazon.” Environmental Research Letters 6(2): 024010.

Armenteras, D., Rodríguez, N., Retana, J. 2009. Are conservation strategies effective in avoiding the deforestation of the Colombian Guyana Shield? Biological Conservation, Vol.142, No.7, pp.14111419.

Asner, Gregory P., David E. Knapp, Eben N. Broadbent, Paulo J. C. Olivieira, Michael Keller, Jose N. Silva. 2005. Selective Logging in the Brazilian Amazon. Science, 310 (5747), pages 480-482. DOI: $10.1126 /$ science. 1118051. 
Assunção, J., and Rocha, R. 2014. Getting Greener by Going Black: The Priority Municipalities in Brazil. Technical Paper. Rio de Janeiro, Brazil, Climate Policy Initiative.

Assunção, J., Gandour, C.C., and Rocha, R. 2014. Deterring Deforestation in the Brazilian Amazon:

Environmental Monitoring and Law Enforcement, Climate Policy Initiative, Rio de Janeiro, Brazil.

Assunção, J., Gandour, C.C., and Rocha, R. 2015. "Deforestation slowdown in the Brazilian Amazon: prices or policies?" Environment and Development Economics 20(06): 697-722.

Assunção, J., Gandour, C.C., Rocha, R., and Rocha, R. 2013. Does Credit Affect Deforestation? Evidence from a Rural Credit Policy in the Brazilian Amazon. C. P. Initiative. Rio de Janeiro, Brazil.

Assunção, Juliano, Clarissa Gandour, Romero Rocha, Rudi Rocha. 2013. Does Credit A!ect

Deforestation? Evidence from a Rural Credit Policy in the Brazilian Amazon. Climate Policy Initiative (CPI), Rio de Janeiro. https://climatepolicyinitiative.org/wpcontent/uploads/2013/01/Does-Credit-Affect-Deforestation-Evidence-from-a-Rural-Credit-Policyin-the-Brazilian-Amazon-Technical-Paper-English.pdf.

Azevedo, Andrea; Rajão, Raoni; Costa, Marcelo; Stabile, Marcelo; Alencar, Ane; Moutinho, Paulo. 2014. "Rural environmental registry and its influence on the dynamics of deforestation in the Legal Amazon.” Amazon Highlights, No. 3. Brasília: IPAM, May 2014.

Baccini, A., Walker, W., Carvalho, L., Farina, M., Sulla-Menashe, D., and Houghton, R.A. 2017. Tropical forests are a net carbon source based on aboveground measurements of gain and loss. DOI: 10.1126/science.aam5962originally published online September 28, 2017.

Bamberger, M., Rao, V., and Woolcock, M. 2010. Using Mixed Methods in Monitoring and Evaluation: Experiences from International Development. World Bank Policy Research Working Paper No. 5245. Available at SSRN: https://ssrn.com/abstract=1578113.

Barbier, E., and Burgess, J. 1996. "Economic Analysis of Deforestation in Mexico.” Environment and Development Economics, 1:203-239.

Barona, E., Ramankutty, N., Hyman, G., and Coomes, O.T. 2010. The role of pasture and soybean in deforestation of the Brazilian Amazon. Environmental Research Letters, 5(2) Published 16 April 2010.

Bastos, J.L., Santos, R.V., Cruz, O.G., Ferreira de Barros Longo, L.A., and da Silva, L.O. 2017. Sociodemographic characteristics of indigenous population according to the 2000 and 2010 Brazilian demographic censuses: a comparative approach. Cad. Saúde Pública [online]. 2017, vol.33, suppl.1. DOI: http://dx.doi.org/10.1590/0102-311x00085516. 
Baylis, Kathy; Jordi Honey-Rosés; Jan Börner; Esteve Corbera; Driss Ezzine-de-Blas; Paul J.

Ferraro; Renaud Lapeyre; U. Martin Persson; Alex Pfaff; Sven Wunder. 2016. "Mainstreaming impact evaluation in nature conservation." Conservation Letters. 9(1):58-64.

Becker, G. 1968. “Crime and punishment: An economic approach.” Journal of Political Economy. 76:169-217.

Beekman, G., Bulte, E., and Nillesen, E. 2014. "Corruption and Economic Activity: Micro Level Evidence from Rural Liberia," Journal of Public Economics, 115: 37-47.

Beekman, G., Gatto, M., and Nillesen, E. 2015. "Family Networks and Income Hiding: Evidence from Lab-in-the-Field Experiments in Rural Liberia,” Journal of African Economies, 24: 453-469.

BenYishay, A., Heuser, S., Runfola, D., and Trichler, R. 2015. "Indigenous Land Rights and Deforestation: Evidence from the Brazilian Amazon." Submitted to the Journal of Environmental Economics and Management.

BenYishay. 2016. Evaluation Report. Geospatial Impact Evaluation of the Demarcation of Indian Territories Project (PPTAL) on Conflict and Deforestation. A collaboration between AidData and KfW. November 2016.

Berg-Nordlie, M., Saglie, J., and Sullivan, A. 2016. Indigenous Politics: Institutions, Representation, Mobilisation. ECPR Press.

Besley, T. 1995. "Property Rights and Investment Incentives: Theory and Evidence from Ghana." Journal of Political Economy 103,(5): 903-937.

Blackman, A., Asner, G., Corral, L., and Santos, E. 2013. "Does land titling stem forest damage? Native communities in the Peruvian Amazon." Resources for the Future Working Paper.

Blohmke, Julian; Kemp, René; Türkeli, Serdar. 2016. "Disentangling the causal structure behind environmental regulation," Technological Forecasting and Social Change, Elsevier, vol. 103(C), pages 174-190.

Bohn, H., and Deacon, R.T. 2000. "Ownership risk, investment, and the use of natural resources." American Economic Review 526-549.

Borges, A.L.V., do Nascimento Chofakian, C.B., Sato, A.P.S., Fujimori, E., Duarte, L.S., and Gomes, M.N. 2016. Fertility rates among very young adolescent women: temporal and spatial trends in Brazil. BMC Pregnancy and Childbirth (2016) 16:57. DOI 10.1186/s12884-016-0843-x.

Börner, J., and Wunder, S. 2008. "Paying for Avoided Deforestation in the Brazilian Amazon: From Cost Assessment to Scheme Design.” International Forestry Review 10(3), 496-511. 
Börner, J., Kis-Katos, K., Hargrave, J., and König, K. 2015. "Post-Crackdown Effectiveness of FieldBased Forest Law Enforcement in the Brazilian Amazon.” Plos One 10(4): e0121544.

Börner, J., Kis-Katos, K., Hargrave, J., and König, K. 2015. Post-Crackdown Effectiveness of FieldBased Forest Law Enforcement in the Brazilian Amazon. PLoS ONE 10(4): e0121544. oi:10.1371/journal.pone.0121544.

Börner, J., Marinho, E., and Wunder, S. 2015. "Mixing Carrots and Sticks to Conserve Forests in the Brazilian Amazon: A Spatial Probabilistic Modeling Approach.” Ed. Chris T. Bauch. Plos One 10.2 (2015): e0116846.

Börner, J., Wunder, S., Wertz-Kanounnikoff, S., Hyman, G., and Nascimento, N. 2011. REDD sticks and carrots in the Brazilian Amazon: Assessing costs and livelihood implications. CCAFS Working Paper no. 8. CGIAR Research Program on Climate Change, Agriculture and Food Security (CCAFS). Copenhagen, Denmark. Available online at: www.ccafs.cgiar.org.

Börner, J., Wunder, S., Wertz-Kanounnikoff, S., Hyman, G., and Nascimento, N. 2014. Forest law enforcement in the Brazilian Amazon: Costs and income effects, Global Environmental Change, 29, 2014, 294-305.

Börner, Jan, Kathy Baylis, Esteve Corbera, Driss Ezzine-de-Blas, Paul J. Ferraro, Jordi Honey-Rosés, Renaud Lapeyre, U. Martin Persson, Sven Wunder. 2016. Emerging Evidence on the Effectiveness of Tropical Forest Conservation. Published: November 2, 2016. In: https://doi.org/10.1371/journal.pone.0159152.

Boucher, D., Roquemore, S., and Fitzhugh, E. 2013. Brazil's Success in Reducing Deforestation. Tropical Conservation Science. https://doi.org/10.1177/194008291300600308.

Buchanan, G., Parks, B., Donald, P., O’Donnell, B., Swaddle, J., Tracewski, L., and Butchart, S. 2015. "Evidence for conservation benefits of World Bank development projects." Working paper.

Bulte, E., and Nillesen, E. 2014. "Corruption, investments and contributions to public goods: Experimental evidence from rural Liberia." Journal of Public Economics 115:37-47, NorthHolland, 2014, 0047-2727.

Buntaine, M., Hamilton, S., and Millones, M. 2015. "Titling Community Land to Prevent Deforestation: An Evaluation of a Best-Case Program in Morona-Santiago, Ecuador." Global Environmental Change 33 (2015): 32-43.

Busch, J., and Ferretti-Gallon, K. 2017. What Drives Deforestation and What Stops It? A MetaAnalysis, Review of Environmental Economics and Policy, 11(1): 3-23, https://doi.org/10.1093/reep/rew013. 
Caldas, M., Walker, R., Arima, E., Perz, S., Aldrich, S. and Simmons, C. 2007. Theorizing Land Cover and Land Use Change: The Peasant Economy of Amazonian Deforestation. Annals of the Association of American Geographers, 97: 86-110. doi:10.1111/j.1467-8306.2007.00525.x.

Cameron, A.C., Gelbach, J.B., and Miller, D.L. 2011. "Robust Inference With Multiway Clustering." Journal of Business \& Economic Statistics 29.2 (2011): 238-249.

Carolin Maier, Theresia Lindner, Georg Winkel. 2014. Stakeholders' perceptions of participation in forest policy: A case study from Baden-Württemberg. Land Use Policy, Volume 39, Pages 166176. ISSN 0264-8377, https://doi.org/10.1016/j.landusepol.2014.02.018.

Carrero, G.C., and Fearnside, P.M.. 2011. Forest clearing dynamics and the expansion of landholdings in Apuí, a deforestation hotspot on Brazil's Transamazon Highway. Ecology and Society 16(2): 26. [online] URL: http://www.ecologyandsociety.org/vol16/iss2/art26/.

Carruthers, I., and Chambers, R. 1981. "Rapid Appraisal for Rural Development,” Agricultural Administration, 8(6):407-422.

Chomitz, K.M., and Thomas, T.S. 2003. "Determinants of Land Use in Amazonia: A Fine-Scale Spatial Analysis." American Journal of Agricultural Economics 85(4): 1016-1028.

Cisneros, E., Zhou, S.L., and Börner, J. 2015. Naming and Shaming for Conservation: Evidence from the Brazilian Amazon. Plos One 10(9): e0136402. doi:10.1371/journal.pone.0136402.

Cohen, J. 1988. Statistical power analysis for the behavioral sciences (2nd ed.). Hillsdale, NJ: Lawrence Earlbaum Associates.

Coimbra, C.E.A., Santos, R.V., Welch, J.R., Cardoso, A.M., Carvalho de Souza, M., Garnelo, L., Rassi, E., Follér, M-L., and Horta, B.L. 2013. The First National Survey of Indigenous People's Health and Nutrition in Brazil: rationale, methodology, and overview of results. BMC Public Health 2013, 13:52. http://www.biomedcentral.com/1471-2458/13/52.

Davidson, E.A., de Araújo, A.C., Artaxo, P., Balch, J.K., Brown, I., Foster, C.M., Coe, M.T., DeFries, R.S., Keller, M., Longo, M., Munger, J.W., Schroeder, W., Soares-Filho, B.S., Souza, C.M., and Wofsy, S.C. 2012. "The Amazon basin in transition." Nature, 481, 321. http://dx.doi.org/10.1038/nature10717.

De Brauw, A., Gilligan, D.O., Hoddinott, J., and Roy, S. 2015. "The Impact of Bolsa Família on Schooling." World Development, 70(supplement c): 303-316. https://doi.org/10.1016/j.worlddev.2015.02.001.

Deininger, K., and Minten, B. 2002. "Determinants of deforestation and the economics of protection: an application to Mexico." American Journal of Agricultural Economics 84, 943-960. 
Donat, M.G., Alexander, L.V., Yang, H., Durre, I., Vose, R., Dunn, R.J.H., Willett, K.M., Aguilar, E., Brunet, M., Caesar, J., Hewitson, B., Jack, C., Klein Tank, A.M.G., Kruger, A.C., Marengo, J.A. Peterson, T.C., Renom, M., Oria Rojas, C., Rusticucci, M., Salinger, J., Sanhouri Elrayah, A., Sekele, S.S., Srivastava, A.K., Trewin, B., Villarroel, C., Vincent, L.A., Zhai, P., Zhang, X., and Kitching, S. 2013. "Updated analyses of temperature and precipitation extreme indices since the beginning of the twentieth century: the HadEX2 dataset." Journal of Geophysical Research: Atmospheres, 118(5), 2098-2118.

Dunteman, G.H. 1989. Principal Components Analysis. Newbury Park, CA: SAGE.

Ehrardt-Martinez, K., Crenshaw, E., Jenkins, J., 2002. Deforestation and the environmental Kuznets curve: cross-national evaluation of intervening mechanisms. Social Science Quarterly 83, 226243.

Espindola, Giovana M. de, Ana Paula D. de Aguiar, Edzer Pebesma, Gilberto Câmara, Leila Fonseca. 2012. Agricultural land use dynamics in the Brazilian Amazon based on remote sensing and census data. Applied Geography, Volume 32, Issue 2, pages 240-252, ISSN 0143-6228. https://doi.org/10.1016/j.apgeog.2011.04.003.

Exbrayat, J.-F., Liu, Y.Y., and Williams, M. 2017. "Impact of deforestation and climate on the Amazon Basin's above-ground biomass during 1993-2012." Scientific Reports, 15615, 7, 1, 2045 2322. https://doi.org/10.1038/s41598-017-15788-6.

Fadda, S., and Tridico, P. 2016. Varieties of Economic Inequality. Routledge Advances in Heterodox Economics. Routledge: New York, N.Y.

FAO. 2011. The state of forests in the Amazon basin, Congo basin and southeast Asia. A report prepared for the summit of the three rainforest basins Brazzaville, Republic of Congo. Brazzaville: FAO.

Feather, C. 2009. The restless life of the Nahua: Shaping people and places in the Peruvian Amazon. In M.N. Alexiades, ed. Mobility and Migration in Contemporary Amazonia: Contemporary ethnoecological perspectives. New York: Berghahn Books, pp. 69-85.

Ferraro, P.J. 2011. "The Future of Payments for Environmental Services.” Conservation Biology 25(6), 1134-1138.

Ferraro, P.J., Hanauerb, M.M., Mitevac, D.A., Nelsone, J.L., Pattanayakg, S.K., Nolte, C., and Sims, K.R.E. 2015. "Estimating the impacts of conservation on ecosystem services and poverty by integrating modeling and evaluation." PNAS, June 16, 2015, 112(24): 7420-7425.

FUNAI. 2008. Paumaria do Lago Marahã. Coletania de Documentos da Terra Indígena. Brasília. FUNAI. 2017. [Online]. http://www.funai.gov.br/index.php/indios-no-brasil/terras-indigenas. 
Garoupa, N. 1997. “The Theory of Optimal Law Enforcement.” Journal of Economic Surveys 11: 267-295.

Geist, Helmut J. and Eric F. Lambin. What Drives Tropical Deforestation? A meta-analysis of proximate and underlying causes of deforestation based on subnational case study evidence. Louvain-la-Neuve.

Gelman, Andrew and Jennifer Hill. 2007. Data Analysis Using Regression and Multilevel/ Hierarchical Models. New York, NY: Cambridge University Press.

George, A.L., and Bennett, A. 2005. Case Studies and Theory Development in the Social Sciences. Cambridge, MA: MIT Press.

Gibbs, H., Rausch, L., Munger, J., Schelly, I., Morton, D., Noojipady, P., Soares-Filho, B., Barreto, P., Micol, L., and Walker, N. 2015. “Brazil’s Soy Moratorium.” Science 347(6220): 377-378.

Gils Hein A. M. J. van and Analia V. Loza Armand Ugon. 2006. What Drives Conversion of Tropical Forest in Carrasco Province, Bolivia? Ambio, Vol. 35, No. 2, pp. 81-85. Springer on behalf of Royal Swedish Academy of Sciences. Stable URL: http://www.jstor.org/stable/4315690.

Glewwe, P. and A.L. Kassouf. 2012. The impact of the Bolsa Escola/Familia conditional cash transfer program on enrollment, dropout rates and grade promotion in Brazil. Journal of Development Economics 97 (2012), Pages 505-517.

Glewwe, P., and Kassouf, A.L. 2012. "The impact of the Bolsa Escola/Família conditional cash transfer program on enrollment, dropout rates and grade promotion in Brazil." Journal of Development Economics, 97(2): 505-517.

Goodhart, D. 2017. The Road to Somewhere: The Populist Revolt and the Future of Politics. Oxford University Press.

Gouvello, C. de. 2010. Brazil Low-carbon Country Case Study. World Bank, Washington, D.C. https://openknowledge.worldbank.org/handle/10986/19286 License: CC BY 3.0 IGO.

Gregersen, H., El Lakany, H., Karsenty, A., and White, A. 2010. Does the Opportunity Cost Approach Indicate the Real Cost of REDD+? Washington, D.C.: Rights and Resources Initiative.

GTZ. 2006. Schlussbericht an das BMZ. Brasilien. KV-Demarkierung von IndianergebietenPPTAL. 2001.2117.8.

Guanais, F.C. 2015. "The Combined Effects of the Expansion of Primary Health Care and Conditional Cash Transfers on Infant Mortality in Brazil, 1998-2010." American Journal of Public Health, 105(S4): 593-599. doi: 10.2105/AJPH.2013.301452r. 
Hall, A. 2008. "Brazil's Bolsa Família: A Double-Edged Sword?" Development and Change 39(5): 799-822. DOI: 10.1111/j.1467-7660.2008.00506.x.

Hardin, Garrett. 1968. The Tragedy of the Commons. Science, New Series, Vol. 162, No. 3859, pp. 1243-1248. Stable URL: http://www.jstor.org/stable/1724745.

Hargrave, J. \& Kis-Katos, K. 2013. Economic Causes of Deforestation in the Brazilian Amazon: A Panel Data Analysis for the 2000s. Environ Resource Econ 54: 471. https://doi.org/10.1007/s10640-012-9610-2.

Hargrave, J., and Kis-Katos, K. 2013. "Economic Causes of Deforestation in the Brazilian Amazon: A Panel Data Analysis for the 2000s.” Environmental Resource Economics 54: 471. doi:10.1007/s10640-012-9610-2.

Hemming, J. 1978. Red Gold: The Conquest of the Brazilian Indians, 1500-1760. Cambridge, MA: Harvard University Press.

Henseler Jörg and Wynne W. Chin. 2010. A Comparison of Approaches for the Analysis of Interaction Effects Between Latent Variables Using Partial Least Squares Path Modeling, Structural Equation Modeling: A Multidisciplinary Journal, 17:1, 82-109, DOI: 10.1080/10705510903439003. http://dx.doi.org/10.1080/10705510903439003.

Hern, W.M. 1991. "Health and demography of native Amazonians: historical perspective and current status." University of Colorado, Boulder, Colorado, 80309-0233. Cad. Saúde Pública 7(4) Rio de Janeiro Oct./Dec. 1991. http://dx.doi.org/10.1590/S0102-311X1991000400002.

Heuser, S. 2013. "Brazil—Demarcation of Indigenous Territories in Brazil (PPTAL).” Ex-Post Evaluation. KfW Development Bank.

Heuser, S. 2015. “Guyana—Conservation of Tropical Forests, GPAS I (BMZ-No.: 199865 809).” An Ex-Post Evaluation. KfW Development Bank.

Heuser, S., and Thomas, V. 2013. Natural Disasters and Climate Change: New Challenges for International Cooperation. In: Öhlschläger and Sangmeister, From Development Assistance to International Cooperation. Global Economy and International Cooperation.

Hinkle, D.E., Wiersma, W., and Jurs, S.G. 2003. Applied statistics for the behavioral sciences. Boston, Mass: Houghton Mifflin.

Honey-Rosés, J., Baylis, K., and Ramirez, I. 2011. "Do our conservation programs work? A spatially explicit estimator of avoided forest loss." Conservation Biology 25 (5), 1032-1043. http://documents.worldbank.org/curated/en/2007/01/9761321/brazil-indigenous-lands-project. 
Howley, P., Hynes, S., and O’Donoghue, C. 2012. "Explaining the non-economic behaviour of farm foresters: The effect of productivist and lifestyle motivations," Working Papers 1203, Rural Economy and Development Programme, Teagasc.

Huang, M., and Asner, G.P. 2010. Long-term Carbon Loss and Recovery Following Selective Logging in Amazon Forests. Global Biogeochem Cycles. 2010. Doi:10.1029/2009GB003727.

Hynes, S., Hanley, N., and O’Donoghue, C. 2010. “A Combinatorial Optimization Approach to Nonmarket Environmental Benefit Aggregation via Simulated Populations," Land Economics 86(2): 345-362.

IBGE. 2012. Os indígenas no Censo Demográfico 2010 primeiras considerações com base no quesito cor ou raça. Rio de Janeiro. in Amazonia, edited by Marianne Schmink and Charles H. Wood, University of Florida Press, Gainesville, FL.

IEG-World Bank. 2012. Designing a results framework for achieving results: A how-to guide. Washington, D.C.

IEG-World Bank. 2013. Managing Forest Resources for Sustainable Development. An Evaluation of World Bank Group Experience.

International Labor Organization. 1989. Indigenous and Tribal Peoples Convention (No. 169). Geneva: ILO. http://www.ilo.org/dyn/normlex/en/f?p=NORMLEXPUB:12100:0::NO::P12100_ILO_CODE:C169.

IPCC. 2014, Part B: Larsen, J.N., O.A. Anisimov, A. Constable, A.B. Hollowed, N. Maynard, P. Prestrud, T.D. Prowse, and J.M.R. Stone. 2014: Polar regions. In: Climate Change 2014: Impacts, Adaptation, and Vulnerability. Part B: Regional Aspects. Contribution of Working Group II to the Fifth Assessment Report of the Intergovernmental Panel on Climate Change [Barros, V.R., C.B. Field, D.J. Dokken, M.D. Mastrandrea, K.J. Mach, T.E. Bilir, M. Chatterjee, K.L. Ebi, Y.O. Estrada, R.C. Genova, B. Girma, E.S. Kissel, A.N. Levy, S. MacCracken, P.R. Mastrandrea, and L.L. White (eds.)]. Cambridge University Press, Cambridge, United Kingdom and New York, NY, $1567-1612$.

Jalan, Jyotsna and Martin Ravallion. 1998. Are there dynamic gains from a poor-area development program? Journal of Public Economics, Volume 67, Issue 1, pages 65-85, ISSN 0047-2727, https://doi.org/10.1016/S0047-2727(97)00052-2.

Joppa, L.N., and Pfaff, A. 2011. Global protected area impacts. Proceedings of the Royal Society: Biological Science 278, 1633.

Kaimowitz, David and Arild Angelsen. 1998. Economic Models of Tropical Deforestation. A Review. Center for International Forestry Research Bogor, Indonesia. 
Katz, E. 2010. Land Tenure, Property Rights, and Natural Resource Management: Land tenure and property rights reform in the developing world: Who is vulnerable? Burlington, VT: USAID.

Keane, A., Jones, J.P.G., Edwards-Jones, G., and Milner-Gulland, E.J. 2008. “The sleeping policeman: understanding issues of enforcement and compliance in conservation." Animal Conservation. 11(2):75-82.

Kemp, R., and Never, B. 2016. "Green transition, industrial policy, and economic development," Oxford Review of Economic Policy, 33(1): 66-84.

Kemp, R., and Pontoglio, S. 2011. "The innovation effects of environmental policy instruments-A typical case of the blind men and the elephant?" Ecological Economics, 72: 28-36.

Kemp, R., Diaz Lopez, F.J., and Bleischwitz, R.R. 2013. Report on Green Growth and Ecoinnovation. Deliverable 2.2 of the FP7 Project "EMInInn - Environmental Macro-Indicators of Innovation." Maastricht University, Netherlands Organisation for Applied Scientific Research TNO and Wuppertal Institute for Climate, Energy and the Environment, Maastricht, Delft and Wuppertal, 92pn.

Kirby, K.R., Laurance, W.F., Albernaz, A.K., Schroth, G., Fearnside, P.M., Bergen, S., Venticinque, E.M., and da Costa, C. 2006. "The future of deforestation in the Brazilian Amazon." Futures, 38(4): 432-453. https://doi.org/10.1016/j.futures.2005.07.011.

L'Roe, Jessica, Lisa Rausch, Jacob Munger, Holly K. Gibbs. 2016. Mapping properties to monitor forests: Landholder response to a large environmental registration program in the Brazilian Amazon. Land Use Policy, Volume 57, pages 193-203, ISSN 0264-8377, https://doi.org/10.1016/j.landusepol.2016.05.029.

Lawry S., Samii C., Hall R., Leopold A., Hornby D., and Mtero F. 2014. The impact of land property rights interventions on investment and agricultural productivity in developing countries: A systematic review. Campbell Systematic Reviews, 2014, 1.

Le Tourneau, F.-M. 2015. The Sustainability Challenges of Indigenous territories in Brazil's Amazonia. Current Opinion in Environmental Sustainability, Elsevier, 2015, 213-220.

Legewie, Nicolas. 2013. An introduction to applied data analysis with qualitative comparative analysis (QCA). Forum: Qualitative Social Research. 14.

Leipold, S., and Winkel, G. 2016. "Discursive Agency: (Re-)Conceptualising actors and practices in the analysis of discursive policy making." Policy Studies Journal. Available online: http://onlinelibrary.wiley.com/doi/10.1111/psj.12172/abstract 7. 
Leipold, S., Frei, T., Sotirov, M., and Winkel, G. 2016. "Protecting 'First World' Markets and 'Third

World' Nature: The Politics of Illegal Logging in Australia, the European Union and the United

States." Global Environmental Change 39, 294-304.

Leuveld, Koen, Eleonora Nillesen, Janneke Pieters, Martha Ross, Maarten Voors, Soazic Elise Wang

Sonne. 2018. Agricultural extension and input subsidies to reduce food insecurity. Evidence from a field experiment in the Congo. United Nations University, UNU-MERIT: Working Paper Series. Maastricht Graduate School of Governance, MGSoG.

Levy, H., Nogueira, J.R., Bezerra de Siqueira, R., Immervoll, H., and O’Donoghue, C. 2008.

"Simulating the impact of inflation on the progressivity of personal income tax in Brazil,"

LATINMOD Working Papers Series 2008-01, Tecnológico de Monterrey, Campus Ciudad de México.

Lisansky, J. 2005. Fostering Change for Brazil's Indigenous People: The Role of the Pilot

Programme. - In: Hall, A. (ed.): Global Impact, Local Action: New Environmental Policy in Latin America: 170-186, London (Institute for the Study of the Americas, University of London).

López-Carr, D., and Burgdorfer, J. 2013. "Deforestation Drivers: Population, Migration, and Tropical Land Use." Environment: Science and Policy for Sustainable Development, 55(1): 3-11.

Lucas N. Joppa, Scott R. Loarie, Stuart L. Pimm. 2008. On the protection of "protected areas."

Proceedings of the National Academy of Sciences, 105 (18) 6673-6678; DOI:

10.1073/pnas.0802471105.

Macedo, M.N., DeFries, R.S., Morton, D.C., Stickler, C.M., Galford, G.L., and Shimabukuro, Y.E. 2012. "Decoupling of deforestation and soy production in the southern Amazon during the late 2000s.” PNAS 109(4):1341-1346; published ahead of print January 9, 2012, doi:10.1073/pnas.1111374109.

Maddison, A. 1988. "Ultimate and Proximate Growth Causality: A Critique of Mancur Olson on the Rise and Decline of Nations," Scandinavian Economic History Review, 2, 1988: 25-9.

Maier, C., Lindner, T., and Winkel, G. 2014. "Stakeholders' Perceptions of Participation in Forest Policy. A case study from Baden-Württemberg.” Land Use Policy 39 (2014) 166-176.

Malhi, Y., Roberts, J.T., Betts, R.A., Killeen, T.J., Li, W., and Nobre, C.A. 2008. "Climate Change, Deforestation, and the Fate of the Amazon." Science 319(5860): 169-172, DOI:

10.1126/science. 1146961 .

Mather, A., Needle, C., 1999. Environmental Kuznets curves and forest trends. Geography 84, 55-65. 
McAlpine, C.A., Etter, A., Fearnside, P.M., Seabrook, L., and Laurance, W.F. 2009. "Increasing world consumption of beef as a driver of regional and global change: A call for policy action based on evidence from Queensland (Australia), Colombia and Brazil.” Global Environmental Change, 19(1), 21-33. https://doi.org/10.1016/j.gloenvcha.2008.10.008.

McSweeney, K., and Arps, S. 2005. “A 'Demographic Turnaround': The Rapid Growth of Indigenous Populations in Lowland Latin America." Latin American Research Review 40(1): 3-29.

Menendez, L.L. 2011. A Alma Vestida : Estodo sobre a Cestaria Paumari. Dou-torado em Ciências Sociais. São Paulo.

Mertens, B., Kaimowitz, D., Puntdewo, A., Vanclay, J., Mendez, P. 2004. "Modeling deforestation at district geographic scales in time periods in Santa Cruz, Bolivia." International Regional Science Review 27(3): 271-296.

Millo, G., and Piras, G. 2012. "splm: Spatial Panel Data Models in R.” Journal of Statistical Software, 2012, 47(01).

Morra Imas, L.G., and Rist, R.C. 2009. The road to results. Designing and conducting effective development evaluations. The World Bank: Washington, D.C.

Muradian, R. , Arsel, M. , Pellegrini, L., Adaman, F., Aguilar, B. , Agarwal, B. , Corbera, E. , Ezzine de Blas, D. , Farley, J. , Froger, G. , Garcia-Frapolli, E. , Gómez-Baggethun, E. , Gowdy, J. , Kosoy, N. , Le Coq, J. , Leroy, P. , May, P. , Méral, P. , Mibielli, P., Norgaard, R. , Ozkaynak, B. , Pascual, U., Pengue, W. , Perez, M. , Pesche, D. , Pirard, R. , Ramos-Martin, J. , Rival, L. , Saenz, F. , Hecken, G. , Vatn, A. , Vira, B. and Urama, K. (2013), Payments for ecosystem services and the fatal attraction of win-win solutions. Conservation Letters, 6: 274-279. doi:10.1111/j.1755263X.2012.00309.x

Nazmi, N. 1991. "Deforestation and Economic Growth in Brazil: Lessons from Conventional Economics," The Centennial Review, 35(2): 315-322. Stable URL: http://www.jstor.org/stable/23739130.

Nelson, A., and Chomitz, K. 2011. "Effectiveness of Strict vs. Multiple Use Protected Areas in Reducing Tropical Forest Fires: A Global Analysis Using Matching Methods.” Plos One 6(8).

Nelson, G., Harris, V., and Stone, S. 2011. "Deforestation, Land Use, and Property Rights: Empirical Evidence from Darien, Panama." Land Economics, 77(2) (2001): 187-205.

Nelson, Gerald \& Harris, GVirginia \& W. Stone, Steven. 2001. Deforestation, Land Use, and Property Rights: Empirical Evidence from Darién, Panama. Land Economics. 77. $10.2307 / 3147089$. 
Nepstad, D., McGrath, D., Stickler, C., Alencar, A., Azevedo, A., Swette, B., Bezerra, T., DiGiano, M., Shimada, J., Seroa da Motta, R., Armijo, E., Castello, L., Brando, P., Hansen, M.C., McGrathHorn, M., Carvalho, O., and Hess, L. 2014. "Slowing Amazon Deforestation through Public Policy and Interventions in Beef and Soy Supply Chains.” Science 344(6188): 1118-1123.

Nepstad, D., Schwartzman, S., Bamberger, B., Santilli, M., Ray, D., Schlesinger, P., Lefebvre, P., Alencar, A., Prinz, E., Fiske, G., and Rolla, A. 2006. "Inhibition of Amazon Deforestation and Fire by Parks and Indigenous Lands: Inhibition of Amazon Deforestation and Fire." Conservation Biology 20(1): 65-73.

Nepstad, D., Soares-Filho, B., Merry, F., Lima, A., Moutinho, P., Carter, J., Bowman, M., Cattaneo, A., Rodrigues, H., Schwartzman, S., McGrath, D.G., Stickler, C.M., Lubowski, R., Piris-Cabezas, P., Rivero, S., Alencar, A., Almeida, O., and Stella, O. 2009. "The End of Deforestation in the Brazilian Amazon.” Science 326(5958): 1350-1351. DOI: 10.1126/science.1182108.

Nepstad, D.C., Stickler, C.M., and Almeida, O.T. 2006. "Globalization of the Amazon Soy and Beef Industries: Opportunities for Conservation." Conservation Biology, 20: 1595-1603. doi:10.1111/j.1523-1739.2006.00510.x.

Nillesen, E. 2016. "Empty cups? Assessing the impact of civil war violence on coffee farming in Burundi." African Journal of Agricultural and Resource Economics - AFJARE 11(1): 69-83, 2016, 1993-3738.

Nillesen, E., and Bulte, E. 2014. "Natural Resources and Violent Conflict." Annual Review of Resource Economics, 6: 69-83.

Nillesen, E., Halefom, Y., and Nigus, P.M. 2018. The effect of weather index insurance on social capital: Experimental evidence from Ethiopia. MERIT Working Papers 007, United Nations University - Maastricht Economic and Social Research Institute on Innovation and Technology (MERIT).

Nillesen, E., Leuveld, K., Pieters, J., Ross, M., Voors, M., and Wang Sonne, E. 2018. Agricultural extension and input subsidies to reduce food insecurity. Evidence from a field experiment in the Congo. MERIT Working Papers 009, United Nations University - Maastricht Economic and Social Research Institute on Innovation and Technology (MERIT).

Nolte C, Agrawal A, Barreto P. 2013. Setting priorities to avoid deforestation in Amazon protected areas: are we choosing the right indicators? Environmental Research Letters.

Nolte C, Agrawal A. 2013. Linking management effectiveness indicators to observed effects of protected areas on fire occurrence in the Amazon rainforest. Conservation Biology. 
Nolte, C., Agrawal, A., Silvius, K., and Soares-Filho, B. 2013. "Governance regime and location influence avoided deforestation success of protected areas in the Brazilian Amazon." PNAS 110(13) (2013): 4956-4961.

Numata, I., Cochrane, M.A., Souza Jr, C.M., and Sales, M.H. 2011. Carbon emissions from deforestation and forest fragmentation in the Brazilian Amazon. Environmental Research Letters 6, 044003 .

O'Donoghue, C. 1999. "Estimating the Rate of Return to Education using Microsimulation," The Economic and Social Review, Economic and Social Studies 30(3): 249-265.

Ortiga, R.R. 2004. Models for Recognizing Indigenous Land Rights in Latin America Biodiversity series. Washington, D.C.: The World Bank.

Ostrom, Elinor. 1990. Governing the Commons: The Evolution of Institutions for Collective Action. Cambridge, England; New York: Cambridge University Press.

Padoch, C., Brondizio, E., Costa, S., Pinedo-Vasquez, M., Sears, R.R., and Siqueira, A. 2008. "Urban forest and rural cities: multi-sited households, consumption patterns, and forest resources in Amazonia." Ecology and Society 13(2): 2. [online] URL: http://www.ecologyandsociety.org/vol13/iss2/art2/.

Panayotou, T., and Sungsuwan, S. 1994. An Econometric Analysis of the Causes of Tropical Deforestation: The Case of Northeast Thailand. In: The Causes of Tropical Deforestation: The Economic and Statistical Analysis of Factors Giving Rise to the Loss of the Tropical Forests, pages 192-210. University College of London Press.

Parker, R.S. 1999. Brazil—Rio Flood Reconstruction and Prevention Project (Loan 2975-BR). Project Performance Assessment Report. IEG-World Bank: Washington, D.C.

Parker, R.S. 1999. Brazil—Water project for municipalities and low-income areas (Loan 2983). Project Performance Assessment Report. IEG-World Bank: Washington, D.C.

Parker, R.S. 2000. Brazil. First Minas Gerais Water Quality and Pollution Control Project (Loan 3554-BR). Project Performance Assessment Report. IEG-World Bank: Washington, D.C.

Parker, R.S. 2006. Hazards of Nature, Risks to Development. An IEG Evaluation of World Bank Assistance for Natural Disasters. IEG-World Bank: Washington, D.C.

Parker, R.S. 2007. Development Actions and the Rising Incidence of Disasters. Evaluation Brief 4; Washington, D.C. IEG-World Bank.

Parker, R.S. 2010. Water and Development. IEG-World Bank: Washington, D.C. 
Pasca, D. 2005. Breaking the tutelage of the state: Indigenous peoples in Brazil. - In: Hall, A. (ed.): Global Impact, Local Action: New Environmental Policy in Latin America: 142-169, London (Institute for the Study of the Americas, University of London).

Pearson, T.R.H., Brown, S., Murray, L., and Sidman, G. 2017. "Greenhouse gas emissions from tropical forest degradation: an underestimated source.” Carbon Balance Manage (2017) 12:3 DOI 10.1186/s13021-017-0072-2.

Perz, S.G., Warren, J., and Kennedy, D.P. 2008. "Contributions of Racial-Ethnic Reclassification and Demographic Processes to Indigenous Population Resurgence: The Case of Brazil.” Latin American Research Review, 43(2): 7-33.

Pettorelli, N., Vik J.O., Mysterud, A., Gaillard, J.-M., Tucker, C.J., and Stenseth, N.C. 2005. "Using the satellite-derived NDVI to assess ecological responses to environmental change." Trends in ecology \& evolution 20(9): 503-510.

Pfaff Alexander S. P. 1989. What Drives Deforestation in the Brazilian Amazon? Evidence from Satellite and Socioeconomic Data. Journal of Environmental Economics and Management 37, 2643. http:// www.idealibrary.com.

Pfaff, A. 1999. "What Drives Deforestation in the Brazilian Amazon?" Journal of Environmental Economics and Management 37 (1999): 2643.

Pfaff, A., Robalino, J., Sandoval, C., and Herrera, D. 2015. "Protected area types, strategies and impacts in Brazil's Amazon: public protected area strategies do not yield a consistent ranking of protected area types by impact." Phil. Trans. R. Soc. B 370(1681): 20140273. DOI: 10.1098/rstb.2014.0273.

Pfaff, A., Robalino, J., Walker, R., Aldrich, S., Caldas, M., Reis, E., Perz, S., Bohrer, C., Arima, E., Laurance, W. and Kirby, K. 2007. "Road Investments, Spatial Spillovers, and Deforestation in the Brazilian Amazon.” Journal of Regional Science, 47: 109-123. doi:10.1111/j.14679787.2007.00502.x.

Pfaff, A., Robalino, J.A., and Sanchez-Azofeifa, G.A. 2008. "Payments for environmental services: empirical analysis for Costa Rica.” Working Paper Series SAN08-05 Terry Sanford Institute of Public Policy.

Pfaff, A., Robalino, J.A., Lima, E., Sandoval, C., Herrera, L.D. 2014. “Governance, Location and Avoided Deforestation from Protected Areas: Greater Restrictions Can Have Lower Impact, Due to Differences in Location." World Development 55 (2014): 7-20. 
Phillips, O.L., Aragao, L., Lewis, S.L., Fisher, J.B., Lloyd, J., Lopez-Gonzalez, G., Malhi, Y., Monteagudo, A., Peacock, J., and Quesada. C.A. 2009. "Drought sensitivity of the Amazon rainforest." Science, 323(5919), 1344-1347.

Pinker, S. 2011. The Better Angels of our Nature. New York, NY: Viking.

Prager, K., Hagemann, N., Schuler, J., Heyn, N. 2011. "Incentives and enforcement: The institutional design and policy mix for soil conservation in Brandenburg (Germany)." Land Degradation \& Development 22: 111-123.

Pries, L. 2013. Shifting Boundaries of Belonging and New Migration Dynamics in Europe and China. Palgrave Macmillan UK.

Puyravaud, J-P. 2003. "Standardizing the Calculation of the Annual Rate of Deforestation." Forest Ecology and Management. 2003 4/7/; 177(1-3):593-6.

Rajão, R., Azevedo, A.A., Stabile, M.C.C. 2012. "Institutional subversion and deforestation: environmental licensing of rural properties in Mato Grosso" Public Administration and Development 32.3 (2012): 229-244.

Ramos, A. R. 1984. Frontier expansion and Indian peoples in the Brazilian Amazon. In M. Schmink and C. H. Wood, eds., Frontier Expansion in Amazonia, pp. 83-104 Gainesville: University of Florida Press.

Rasella, D., Aquino, R., Santos, C.A.T., Paes-Sousa, R., and Barreto, M.L. 2013. "Effect of a conditional cash transfer programme on childhood mortality: a nationwide analysis of Brazilian municipalities." The Lancet, 382(9886): 57-64. https://doi.org/10.1016/S0140-6736(13)60715-1.

Rehm, M. and van de Laar, M. 2015. The Potential of Communities of Learning for Dual Career PhD Programs-A Case Study, in: A. Dailey-Hebert \& K. S. Dennis, Transformative Perspectives and Processes in Higher Education, Springer International Publishing, Switzerland, 155-177.

Ribeiro, D. 1970. Os Índios e a Civilização. A Integração dos Indígenas no Brasil Moderno. Rio de Janeiro: Editora Civilização Brasileira.

Richards, P.D., Myers, R.J., Swinton, S.M., and Walker, R.T. 2012. "Exchange rates, soybean supply response, and deforestation in South America." Global Environmental Change, 22(2) : 454-462. https://doi.org/10.1016/j.gloenvcha.2012.01.004.

Rigaud, K.K., de Sherbinin, A., Jones, B., Bergmann, J., Clement, V., Ober, K., Schewe, J., Adamo, S., McCusker, B., Heuser, S., and Midgley, A. 2018. Groundswell: Preparing for Internal Climate Migration. World Bank, Washington, DC.

https://openknowledge.worldbank.org/handle/10986/29461 License: CC BY 3.0 IGO. 
Rihoux, B., \& Ragin, C. C. 2009. Applied Social Research Methods: Configurational comparative methods: Qualitative comparative analysis (QCA) and related techniques (Vols. 1-51). Thousand Oaks, CA: SAGE Publications Ltd doi: 10.4135/9781452226569.

Robalino, J., Pfaff, A., and Villalobos, L. 2015. Deforestation spillovers from Costa Rican protected areas (No. 201502). https://ideas.repec.org/p/fcr/wpaper/201502.html.

Robalino, J., Pfaff, A., Sanchez-Azofeifa, G.A., Alpízar, F., León, C., Rodríguez, C.M. 2008. "Changing the deforestation impacts of ecopayments: evaluation (2000-2005) in Costa Rica's PSA program.” Discussion Paper 08-24. Environment for Development, Turrialba, Costa Rica.

Robalino, J., Sandoval, C., Barton, D.N., Chacon, A., and Pfaff, A. 2015. Evaluating interactions of forest conservation policies on avoided deforestation. Plos One, 10(4), e0124910 http://journals.plos.org/plosone/article?id=10.1371/journal.pone.0124910.

Robalino, J., Sandoval, C., Barton, D.N., Chacon, A., and Pfaff, A. 2015. "Evaluating Interactions of Forest Conservation Policies on Avoided Deforestation.” Plos One 10(4).

Robinson, B.E., Holland, M.B., and Naughton-Treves, L. 2014. "Does secure land tenure save forests? A meta-analysis of the relationship between land tenure and tropical deforestation." Global Environmental Change-Human and Policy Dimensions, 29: 281-293. doi: 10.1016/j.gloenvcha.2013.05.012.

Robinson, E.J.Z., Kumar, A.M., and Albers, H.J. 2010. "Protecting Developing Countries' Forests: Enforcement in Theory and Practice.” Journal of Natural Resources Policy Research. 2010; 2(1):25-38.

Rossi, P. , Freeman, H. , and Lipsey, M. 1999. Evaluation: A systematic approach. Thousand Oaks, CA: Sage.

Rossi, P.H., Lipsey, M.W., and Freeman, H.E. 2007. Evaluation: A systematic approach. Thousand Oaks, Calif. u.a.: Sage Publ.

Rudel, Thomas K., Oliver Coomes, Emilio Moran, Frédéric Achard, Arild Angelsen, Jianchu Xu, Eric Lambin, 2005. Forest Transitions: Towards a Global Understanding of Land Use Change. Global Environmental Change; Volume 15, Issue 1, April 2005, Pages 23-31. DO 10.1016/j.gloenvcha.2004.11.001.

Rudorff, Bernardo \& Adami, Marcos \& Risso, Joel \& Aguiar, Daniel \& Pires, Bernardo \& Amaral, Daniel \& Fabiani, Leandro \& Cecarelli, Izabel. (2012). Remote Sensing Images to Detect Soy Plantations in the Amazon Biome-The Soy Moratorium Initiative. Sustainability. 4. 1074-1088. $10.3390 /$ su4051074. 
Rufino, M., Reidsma, P., and Nillesen, E. 2011. Comments to 'Is an integrated farm more resilient against climate change? A micro-econometric analysis of portfolio diversification in African agriculture,' Food Policy, 36(3): 452-454.

Ryan, M., O'Donoghue, C., and Upton, V. 2014. "Land Use Change from Agriculture to Forestry: A Structural Model of the Income and Leisure Choices of Farmers," 2014 International Congress, August 26-29, 2014, Ljubljana, Slovenia 182753, European Association of Agricultural Economists.

Samii, C., Lisiecki, M., Kulkarni, P., Paler, L., and Chavis, L. 2014. Effects of Payment for Environmental Services (PES) on Deforestation and Poverty in Low and Middle-Income Countries: A Systematic Review. Campbell Systematic Reviews. 2014; 10(11).

Sanchez-Ancochea, D., and Mattei, L. 2011. "Bolsa Família, poverty and inequality: Political and economic effects in the short and long run.” Global Social Policy, 11: 299-318. DOI: $10.1177 / 1468018111421297$.

Schäfer, D., Siliverstovs, B., and Terberger, E. 2010. "Banking competition, good or bad? The case of promoting micro and small enterprise finance in Kazakhstan." Applied Economics 42(6).

Schmidt, R.H., and Terberger, E. 1986. Grundzüge der Investitions- und Finanzierungstheorie. Springer: Wiesbaden.

Schmidt, Reinhard H. and Eva Terberger. 1997. Grundzüge der Investitions- und Finanzierungstheorie. - 4., aktualisierte Aufl., Gabler: Wiesbaden.

Schwartzman, S., Boas, A.V., Ono, K.Y., Gesteira Fonseca, M., Doblas, J., Zimmerman, B., Junqueira, P., Jerozolimski, A., Salazar, M., Prates Junqueira, R., and Torres, M. 2013. "The natural and social history of the indigenous lands and protected areas corridor of the Xingu River basin.” Phil Trans R Soc B. 368:20120164.http://dx.doi.org/10.1098/rstb.2012.0164.

Sena, J.A., Freitas, M.A.V., de Berrêdo, D., Costa Fernandes, L. 2012. Evaluation of Vulnerability to Extreme Climatic Events in the Brazilian Amazonia: Methodological Proposal to the Rio Acre Basin. https://link.springer.com/article/10.1007/s11269-012-0166-2.

Sills, E.O., Herrera, D., Kirkpatrick, A.J., Brandão, Jr., A., Dickson, R., Hall, S., Pattanayak, S., Shoch, D., Vedoveto, M., Young, L., and Pfaff, A. 2015. "Estimating the Impacts of Local Policy Innovation: The Synthetic Control Method Applied to Tropical Deforestation." Plos One 10(7): e0132590.

Sims, K. 2010. "Conservation and development: evidence from Thai protected areas." Journal of Environmental Economics and Management 60: 94-114. 
Skeldon, R. 1977. "The Evolution of Migration Patterns during Urbanization in Peru," Geographical Review, 67(4) (Oct. 1977): 394-41.

Skeldon, R. 2006. "Interlinkages Between Internal and International Migration and Development in the Asian Region." Population, Space and Place, 12, 15-30.

Skeldon, R. 2010. "Managing migration for development: is circular migration the answer?" Whitehead Journal of Diplomacy and International Relations, 11 (1): 21-33. ISSN 1936-3419.

Skeldon, R. 2013. "Migration and Asia: Reflections on Continuities and Change," Asia-Pacific Population Journal, 27(1): 103-118.

Skeldon, R. 2013. Bringing migration into the post-2015 agenda: Notes, reflections and policy directions, UNU-MERIT Working Paper 2013-065.

Skeldon, R. and Green, A. 2013. Shifting categories of belonging in the United Kingdom census: changing definitions of migration, labour-market access and experience, in: L. Pries (ed.), Shifting Boundaries of Belonging and New Migration Dynamics in Europe and China, Palgrave Macmillan, London, pp. 107-135.

Soares, F.V., Perez Ribas, R., and Guerreiro Osório, R. 2010. “Evaluating the Impact of Brazil's Bolsa Família: Cash Transfer Programs in Comparative Perspective.” Latin American Research Review. 45(2): 173-190.

Soares-Filho B., Moutinho, P., Nepstad, D., Anderson, A., Rodrigues, H., Garcia, R., Dietzsch, L., Merry, F., Bowman, M., Hissa, L., Silvestrini, R., and Maretti, C. 2010. Role of Brazilian Amazon protected areas in climate change mitigation. PNAS - Proceedings of the National Academy of Sciences of the United States, 107(24):10821-10826.

Soares-Filho, B., Nepstad, D., Curran, L.M., Cerqueira, G.C., Garcia, R.A., Ramos, C.A., Voll, E., McDonald, A., Lefebvre, P., and Schlesinger, P. 2006. "Modelling conservation in the Amazon basin.” Nature 440, 520. http://dx.doi.org/10.1038/nature04389.

Sousa, Paulo Queiroz. 2016. Decreasing Deforestation in the Southern Brazilian Amazon-The Role of Administrative Sanctions in Mato Grosso State, Forests, vol. 7, no. 3, 66, URL = http://www.mdpi.com/1999-4907/7/3/66.

Sri Astuti, E., Offermans, A., Kemp, R., and Corvers, R. 2016. "The Impact of Coffee Certification on the Economic Performance of Indonesian Actors," Asian Journal of Agriculture and Development, 12(2): $1-16$.

Stock J, Watson MW. “Introduction to Econometrics.” Essex, UK, Pearson: 2012.

Stock, J.H., and Watson, M.W. 2007. Introduction to econometrics. Boston: Pearson/Addison Wesley. 
Stocks, A. 2005. "Too much for too few: Problems of indigenous land rights in Latin America." Annual Review of Anthropology 34: 85-104). Palo Alto: Annual Reviews.

Sturgis, Patric. PPT. 2018. Structural Equation Modeling: what is it and what can we use it for? Retrieved on September 23, 2018 from: https://www.youtube.com/watch?v=eKkESdyMG9w.

Sunderlin, W.D., Dewi, S., Puntodewo, A., Muller, D., Angelsen, A., Epprecht, M. 2008. Why forests are important for global poverty alleviation: a spatial explanation. Ecology and Society 13 (2) :24 URL:http://www.ecologyandsociety.org/vol13/iss2/art24/. ISSN: 1708-3087.

Terberger, E. 1997. "Finance against poverty." Journal of Development Economics 54(1):189-194. North-Holland 1997, 0304-3878.

Terberger, E. 2003. "The German financial system: Great institutional change and little effect?" Journal of Institutional and Theoretical Economics 159(4): 707-716. Mohr Siebeck 20030932 4569.

The World Bank. 1995. Brazil - Indigenous Lands Project. Memorandum \& Recommendation of the Director (P006567). http://documents.worldbank.org/curated/en/994921468743396447/BrazilIndigenous-Lands-Project.

Tritsch, I., and Le Tourneau, F.-M. 2016. "Population densities and deforestation in the Brazilian Amazon: New insights on the current human settlement patterns." Applied Geography 76 (2016): 163-172.

UNESCO. 2014. Brazil. Report. Education for All in Brazil 2000-2015 National Review. Retrieved on May 4, 2018 from: file://C:/Users/Silke/Desktop/GPAC2\%20Maastricht/000\%202018\%20revisions/Brazil\%20Litera cy\%20levels.pdf.

UNESCO. 2015. "Education for All 2015 National Review Report: Brazil”. For further information, please contact: efa2015reviews@unesco.org.

UNICEF. 2012. Brazil -- Country programme document. 2012-2016. https://www.unicef.org/about/execboard/files/Brazil_final_approved_20122016_English_10Feb2012_.pdf.

United Nations. 2007. United Nations Declaration on the Rights of Indigenous Peoples. New York: United Nations. http://www.un.org/esa/socdev/unpfii/documents/DRIPS_en.pdf.

Urama, K. 2013. "Payments for Ecosystem Services and the Fatal Attraction of Win-Win Solutions." Conservation Letters, 6(4): 274-279.

Van de Laar, M., and Le, N.T.Q. 2017. Global Employment and Health Insurance: Policy Beyond Borders, Blog Series APPAM conference Brussels 13-14 July 2017, blog 4. 
Van de Laar, M., and Sahoo, M. 2017. Migrant Health in India: APPAM Minority Report \#2, APPAM Minority Report \#2.

Van der Werf, G.R., Morton, D.C., DeFries, R.S., Olivier, J.G.J., Kasibhatla, P.S., Jackson, R.B., Collatz, G.J., and Randerson, J.T. 2009. “ $\mathrm{CO}_{2}$ Emissions from Forest Loss.” Nature Geoscience, 2: 737-738. http://dx.doi.org/10.1038/ngeo671.

Vergara, E.P., and Barton, J.R. 2013. "Poverty and Dependency in Indigenous Rural Livelihoods: Mapuche Experiences in the Andean Foothills of Chile." Journal of Agrarian Change, 13(2): 234262.

Vergara-Aseno, G., and Potvin, C. 2014. "Forest Protection and Tenure Status: The Key Role of Indigenous Peoples and Protected Areas in Panama." Global Environmental Change, 28 (2014): 2015-215.

Von Thünen, J. H. 2009. The Isolated State in Relation to Agriculture and Political Economy. New York, NY: Palgrave Macmillan.

Waddington, H., White, H., Snilstveit, B., Hombrados, J.G., Vojtkova, M., Davies, P., Bhavsar, A., Eyers, J., Koehlmoos, T.P., Petticrew, M., Valentine, J.C., and Tugwell, P. 2012. "How to do a good systematic review of effects in international development: a tool kit," Journal of Development Effectiveness, 4(3): 359-387, DOI: 10.1080/19439342.2012.711765.

Wentzel, S. 2006. Demarcating, Protecting and Managing Indigenous Lands in the Amazon"Lessons" for Borneo? XI Biennial Global Conference of the IASCP: "Survival of the Commons: Mounting Challenge \& New Realities,” June 19-23, 2006, Bali, Indonesia.

Wheeler, D., Hammer, D., Kraft, R., and Steele, A. 2014. Satellite-based forest clearing detection in the Brazilian Amazon: FORMA, DETER, and PRODES. Washington, D.C: World Resources Institute. http://www.wri.org/sites/default/files/forma-issue-brief 1.pdf.

White, Andy and Alejandra Martin. 2002. Who Owns the World's Forests? Forest Tenure and Public Forests in Transition. Forest Trends. Washington, D.C.

White, H. 2009. “Theory-based Impact Evaluation: Principles and Practice." Journal of Development Effectiveness. 1(3): 271-84.

White, H., and Waddington, H. 2012. "Why do we care about evidence synthesis? An introduction to the special issue on systematic reviews," Journal of Development Effectiveness, 4(3): 351-358, DOI: $10.1080 / 19439342.2012 .711343$.

Wiessner Siegfried. 2009. United Nations Declaration on the Rights of Indigenous Peoples. United Nations Audiovisual Library of International Law. www.un.org/law/avl. 
Wiessner, S. 1999. "Rights and Status of Indigenous Peoples: A Global Comparative and International Legal Analysis." Harv. Hum. Rts. J. 57(12): 72.

Wiessner, S. 2011. "The Cultural Rights of Indigenous Peoples: Achievements and Continuing Challenges." European Journal of International Law, 22(1): 121-140. doi: 10.1093/eji1/chr007.

Winkel, G. 2013. "Forest conservation policy in a changing climate" (Editorial). Forest Policy and Economics 36 (2013):1-5.

Wong, Ken Kwong-Kay. 2013. Partial Least Squares Structural Equation Modeling (PLS-SEM) Techniques Using SmartPLS. Marketing Bulletin, 2013, 24, Technical Note 1.

Woolcock, M. 2013. Using Case Studies to Explore the External Validity of 'Complex' Development Interventions. Faculty Research Working Paper Series.

Wooldridge, J.M. 2002. Econometric analysis of cross section and panel data. Cambridge, Mass: MIT Press.

World Bank Group. 2010. Brazil. Second Bolsa Família Project (APL 2). Project Appraisal Document (Project ID: P101504). Washington D.C.

World Bank. 1995. Indigenous Lands Project. Pilot Program to Conserve the Brazilian Rain Forest. Memorandum and Recommendation of the Director of the Latin America and the Caribbean Department to the Regional Vice President on a Proposed Grant from the Rain Forest Trust Fund. Washington, D.C.

World Bank. 2007. Implementation Completion and Results Report: Brazil Indigenous Lands Project (Pilot Program to Conserve the Brazilian Rain Forest) (No. ICR0000338). Washington, D.C.: The World Bank.

World Bank. 2011. Country Partnership Strategy for the Federative Republic of Brazil FY 20122015. Washington, D.C.

World Bank. 2017. World Bank Data. [Online]. https://data.worldbank.org/country/brazil?view=chart. WRI. 2016. Climate Benefits, Tenure Costs. The Economic Case for Securing Indigenous Land Rights in the Amazon. Washington, D.C., written by Helen Ding, Peter G. Veit, Allen Blackman, Erin Gray, Katie Reytar, Juan Carlos Altamirando, And Benjamin Hodgdon, p. 8.

Wunder, S. 2013. "When payments for environmental services will work for conservation." Conservation Letters, 6(4): 230-237.

Yin, R.K. 2009. Case study research: Design and methods (4th Ed.). Thousand Oaks, CA: Sage, p. 18. 
Zucco, Cesar. 2013. Bolsa Familia and the Shift in Lula's Electoral Base, 2002-2006. A Reply to Bohn. Latin American Research Review, Vol. 48, No. 2. 


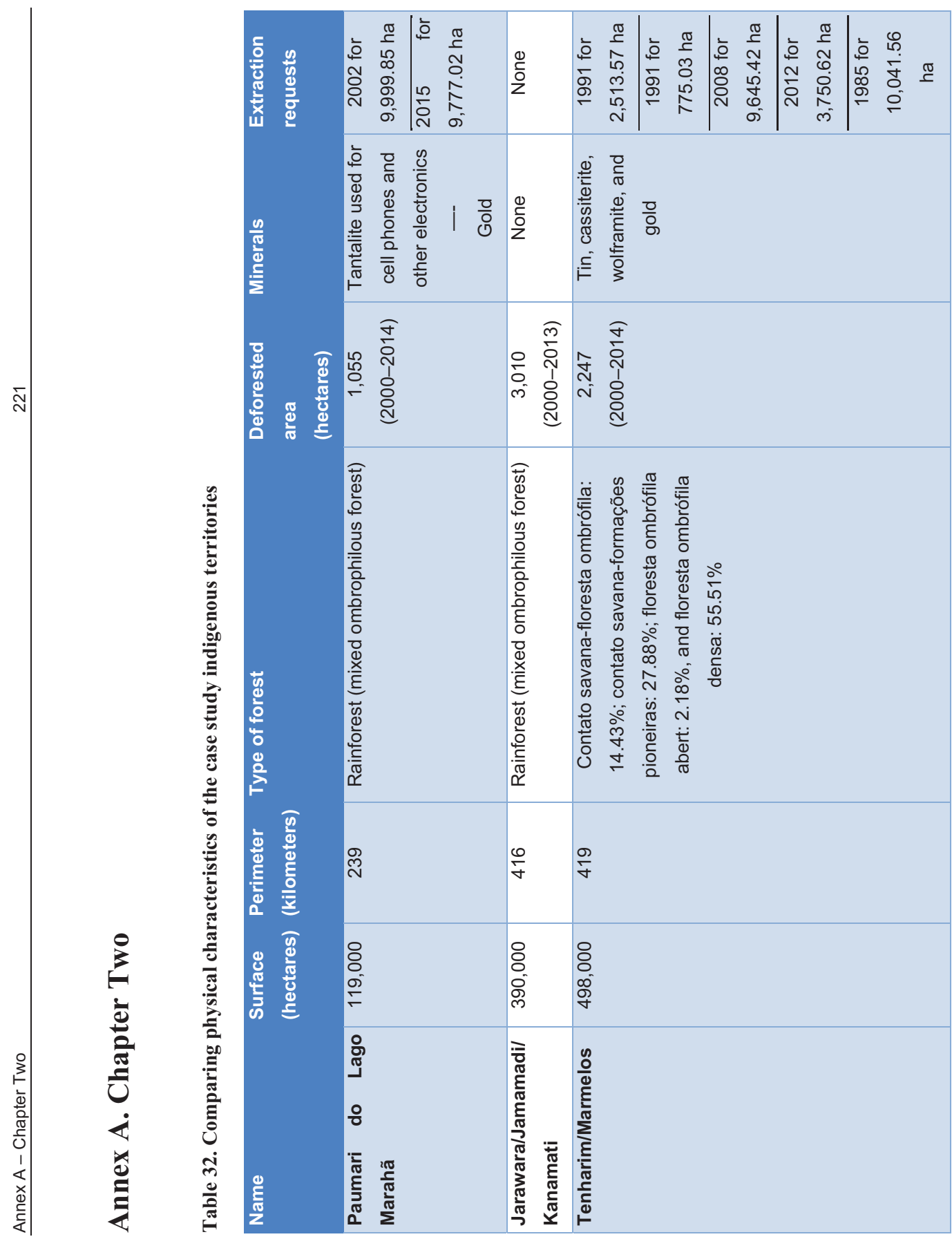




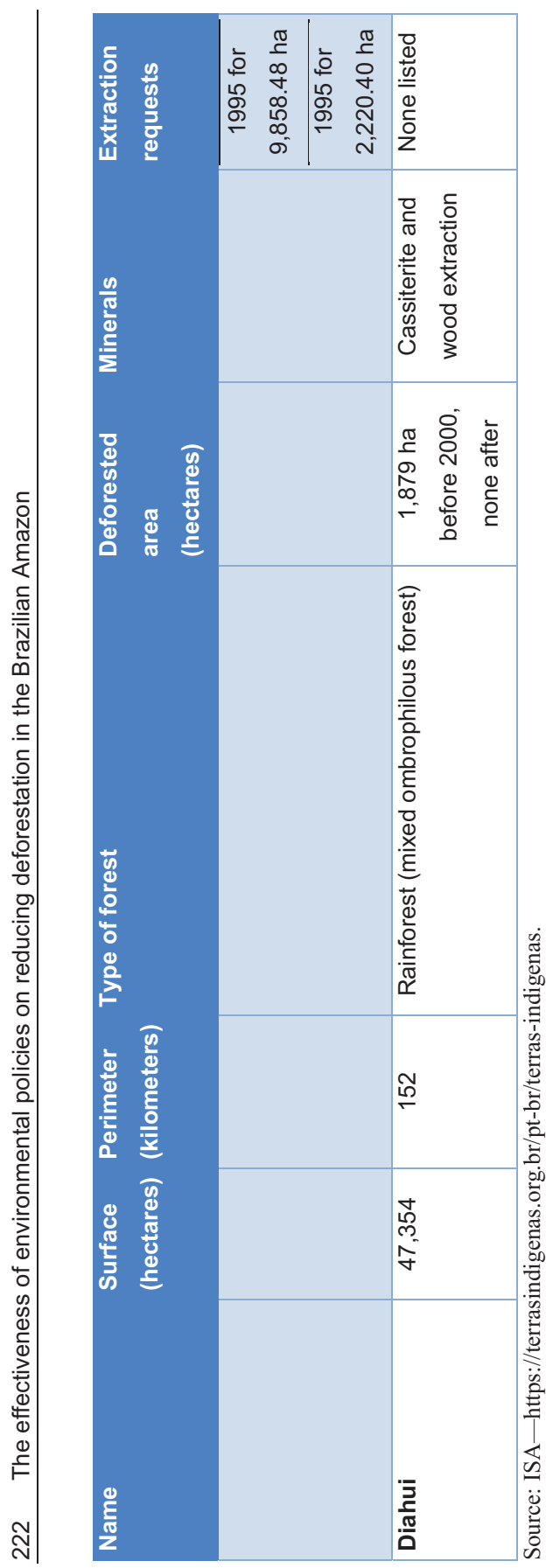


Table 33. Comparing different indigenous communities according to their self-organization and former and current external support

\begin{tabular}{|c|c|c|c|}
\hline Name & $\begin{array}{l}\text { Indigenous self- } \\
\text { organization }\end{array}$ & External support & External projects \\
\hline Paumari do Lago Marahã & $\begin{array}{l}\text { Federação das } \\
\text { Organizações e } \\
\text { Comunidades } \\
\text { Indígenas do Médio } \\
\text { Purus (FOCIMP) } \\
\text { Organização dos } \\
\text { Povos Indígenas do } \\
\text { Médio Purus } \\
\text { (OPIMP) }\end{array}$ & $\begin{array}{l}\text { Operação } \\
\text { Amazônia Nativa } \\
\text { (OPAN) } \\
\text { Conselho } \\
\text { Indigenista } \\
\text { Missionário (CIMI) } \\
\text { German Indian } \\
\text { Pioneer Mission } \\
\text { Sociedade } \\
\text { Internacional de } \\
\text { Lingüística (SIL) }\end{array}$ & None \\
\hline Jarawara/Jamamadi/Kanamati & $\begin{array}{l}\text { Organização dos } \\
\text { Povos Indígenas do } \\
\text { Médio Purus } \\
\text { (OPIMP) }\end{array}$ & $\begin{array}{l}\text { Jovens com uma } \\
\text { Missão (JOCUM) } \\
\text { and the Sociedade } \\
\text { Internacional de } \\
\text { Lingüística (SIL) }\end{array}$ & None \\
\hline Tenharim/Marmelos & $\begin{array}{l}\text { Associação do Povo } \\
\text { Indígena Tenharim } \\
\text { Morõgwitá } \\
\text { (APITEM); } \\
\text { Organização dos } \\
\text { Povos Indigenas } \\
\text { Torá, Tenharim, } \\
\text { Apurinã, Mura, } \\
\text { Parintintin e Pirahã } \\
\text { (OPITTAMPP) }\end{array}$ & $\begin{array}{l}\text { Conselho } \\
\text { Indigenista } \\
\text { Missionário (CIMI); } \\
\text { Sociedade } \\
\text { Internacional de } \\
\text { Lingüística (SIL) }\end{array}$ & $\begin{array}{l}\text { The Amazon Fund } \\
\text { financed a sustainable } \\
\text { environment project in } \\
2014 \text { (called Gestão } \\
\text { Ambiental Sustentável } \\
\text { das Terras Indígenas } \\
\text { do Estado do } \\
\text { Amazonas) }\end{array}$ \\
\hline Diahui & None & $\begin{array}{l}\text { Amazon } \\
\text { Conservation } \\
\text { Team (ACT - } \\
\text { Brasil) }\end{array}$ & $\begin{array}{l}\text { The Amazon Fund } \\
\text { financed a sustainable } \\
\text { environment project in } \\
2014 \text { (called Gestão } \\
\text { Ambiental Sustentável } \\
\text { das Terras Indígenas } \\
\text { do Estado do } \\
\text { Amazonas) }\end{array}$ \\
\hline
\end{tabular}

Source: https://terrasindigenas.org.br/pt-br/terras-indigenas/ 



\section{Annex B. Chapter Four}

\section{DETAILED SEARCH PROTOCOL}

Below I demonstrate how I applied the detailed search strategy and the results I received. I will first present the search protocol and results for Google Scholar and then for the Web of Science.

\section{Google scholar search protocol}

- Go to database website: https://scholar.google.com/

- Go to settings / languages

- Click "search only for papers written in these language(s)

- Click "English" and "save"

- In cluded the following search string [Brazilian Amazon AND deforestation OR protected OR forest OR conservation OR governance]

- The search resulted in 30,500 articles

- Under "Advanced Search"

- Enter search string under "find articles / with all the words":

- In cluded the following search string [Brazilian Amazon AND deforestation OR protected OR forest OR conservation OR governance]

- Click "In title only"

- In the box "return articles dated between" enter "2010" and "2016"

- The search resulted in 215 articles

- I searched for "Soy Moratorium” separately

- The search resulted in 5 articles see Table 34. 
Table 34. Keyword Search Results

\begin{tabular}{|c|c|c|}
\hline Database & Keywords & Articles \\
\hline Google Scholar & $\begin{array}{l}\text { Brazilian Amazon AND deforestation OR } \\
\text { protected OR forest OR conservation OR } \\
\text { governance } \\
\text { Soy Moratorium }\end{array}$ & 1,960 \\
\hline Google Scholar & Soy Moratorium & 1,960 \\
\hline Google Scholar & $\begin{array}{l}\text { allintitle: Brazilian Amazon AND } \\
\text { deforestation OR protected OR forest OR } \\
\text { conservation OR governance }\end{array}$ & 215 \\
\hline Google Scholar & allintitle: Soy Moratorium & 5 \\
\hline
\end{tabular}

Source: Own table

I reviewed titles and abstracts of the 215 studies and included them in a Mendeley database.

I reviewed more closely the following 15 studies that had a promising title and abstract.

1) Amin, A. M., Choumert, J., Combes, J.-L., Motel, P. C., Kere, E. N., Olinga, J. G. O., and Schwartz, S. 2015. A spatial econometric approach to spillover effects between protected areas and deforestation in the Brazilian Amazon, 27. Retrieved from https://halshs.archives-ouvertes.fr/halshs-00960476/.

2) Assunção Clarissa Gandour Romero Rocha, J., and Juliano Assunção, C. 2013. DETERring Deforestation in the Brazilian Amazon: Environmental Monitoring and Law Enforcement CPI Report. Retrieved from https://climatepolicyinitiative.org/wpcontent/uploads/2013/05/DETERring-Deforestation-in-the-Brazilian-AmazonEnvironmental-Monitoring-and-Law-Enforcement-Technical-Paper.pdf.

3) Börner, J., Kis-Katos, K., Hargrave, J., and König, K. 2015. Post-Crackdown Effectiveness of Field-Based Forest Law Enforcement in the Brazilian Amazon. PLoS ONE 10(4): e0121544. oi:10.1371/journal.pone.0121544.

4) Börner, J., Wunder, S., Wertz-Kanounnikoff, S., Hyman, G., and Nascimento, N. 2014. Forest law enforcement in the Brazilian Amazon: Costs and income effects. Global Environmental Change, 29, 294-305. https://doi.org/10.1016/J.GLOENVCHA. 2014.04.021. 
5) Cisneros, E., Zhou, S. L., and Börner, J. 2015. Naming and Shaming for Conservation: Evidence from the Brazilian Amazon. Plos One 10(9): e0136402. doi:10.1371/ journal.pone.0136402.

6) Dias, L. F. O., Dias, D. V., and Magnusson, W. E. 2015. Influence of Environmental Governance on Deforestation in Municipalities of the Brazilian Amazon. PLOS ONE, 10(7), e0131425. https://doi.org/10.1371/journal.pone.0131425.

7) Hargrave, J., and Kis-Katos, K. 2013. Economic Causes of Deforestation in the Brazilian Amazon: A Panel Data Analysis for the 2000s. Environmental and Resource Economics 54(4), 471-494. https://doi.org/10.1007/s10640-012-9610-2.

8) Nepstad, D., McGrath, D., Stickler, C., Alencar, A., Azevedo, A., Swette, B., ... and Hess, L. 2014. Slowing Amazon deforestation through public policy and interventions in beef and soy supply chains. Science 344(6188), 1118-1123. https://doi.org/ $\underline{10.1126 / \text { science. } 1248525 .}$.

9) Nolte, C., Agrawal, A., Silvius, K. M., and Soares-Filho, B. S. 2013. Governance regime and location influence avoided deforestation success of protected areas in the Brazilian Amazon. Proceedings of the National Academy of Sciences of the United States of America, 110(13), 4956-4961. https://doi.org/10.1073/pnas.1214786110.

10) Pfaff, A., and Robalino, J. 2011. Brazilian Amazon Roads and Parks: Temporal and Spatial Deforestation Dynamics. American Geophysical Union, Fall Meeting 2011, Abstract Id. GC32B-06. Retrieved from http://adsabs.harvard.edu/abs/ 2011AGUFMGC32B..06P.

11) Pfaff, A., Robalino, J., Herrera, D., and Sandoval, C. (2015). Protected Areas' Impacts on Brazilian Amazon Deforestation: Examining Conservation - Development Interactions to Inform Planning. PLOS ONE, 10(7), e0129460. https://doi.org/ 10.1371/journal.pone.0129460.

12) Rolla, A., Vedoveto, M., De, S., Futada, M., Veríssimo, A., Caldeira, A. P., ... and Salomão, R. (2011). Protected Areas in the Brazilian Amazon Challenges and Opportunities. Retrieved from http://site1378233601.provisorio.ws/images/ publicacoes/livros/livro_ISA_ingles_25out2011.pdf. 
13) Rudorff, B. F. T., Adami, M., Aguiar, D. A., Moreira, M. A., Mello, M. P., Fabiani, L., ... and Pires, B. M. 2011. The Soy Moratorium in the Amazon Biome Monitored by Remote Sensing Images. Remote Sensing 3(1), 185-202. https://doi.org/ $\underline{10.3390 / \mathrm{rs} 3010185 .}$

14) Rudorff, B. F. T., Adami, M., Risso, J., de Aguiar, D. A., Pires, B., Amaral, D., ... and Cecarelli, I. 2012. Remote Sensing Images to Detect Soy Plantations in the Amazon Biome-The Soy Moratorium Initiative. Sustainability 4(5), 1074-1088. https://doi.org/10.3390/su4051074.

15) Soares-Filho, B., Moutinho, P., Nepstad, D., Anderson, A., Rodrigues, H., Garcia, R., ... and Maretti, C. 2010. Role of Brazilian Amazon protected areas in climate change mitigation. Proceedings of the National Academy of Sciences of the United States of America, 107(24), 10821-10826. https://doi.org/10.1073/pnas.0913048107.

I excluded 10 studies that did not meet my selection criteria.

1) With respect to the Soy Moratorium, I found the following papers, which I reviewed: Gibbs, H., Rausch, L., Munger, J., Schelly, I., Morton, D., Noojipady, P., Soares-Filho, B., Barreto, P., Micol, L., and Walker, N. 2015. "Brazil's Soy Moratorium.” Science 347(6220): 377-378.

2) Rudorff, B. F. T., Adami, M., Aguiar, D. A., Moreira, M. A., and Mello, M. P., Fabiani, L., and Amaral, D. F., and Pires, B. M. 2011. The soy moratorium in the Amazon biome monitored by remote sensing images. Remote Sensing 3(11): 185-202.

3) Rudorff, B.F.T., Adami, M., Risso, J., de Aguiar, D.A., Pires, B., Amaral, D., Fabiani, L., Cecarelli, I. Remote Sensing Images to Detect Soy Plantations in the Amazon Biome-The Soy Moratorium Initiative. Sustainability 2012, 4, 1074-1088.

4) Brown, J. C., and Koeppe, M. 2013. Debates in the Environmentalist Community: The soy moratorium and the construction of illegal soybeans in the Brazilian Amazon, Sussex Academic.

5) Risso, J., Rudorff, B.F.T., Adami, M., Aguiar, A.P.D., and Freitas, R.M. 2012. MODIS Time Series for Land Use Change Detection in Fields of the Amazon Soy Moratorium. 
International Archives of the Photogrammetry, Remote Sensing and Spatial Information Sciences, Melbourne, Australia, Proceedings, vol. 23, pages 339-344.

Following a more detailed review, I excluded all six studies, because they did not meet my selection criteria.

\section{Web of Science search protocol}

I conducted similar searches with the Web of Science database.

- Open Web of Science database:

https://apps.webofknowledge.com/WOS_GeneralSearch_input.do?product=WOS $\underline{\text { \&search } \_ \text {mode }=\text { GeneralSearch } \& S I D=C 486 z V 4 c J 4 m Y G b h h N v B \& p r e f e r e n c e s S a v}$ $\underline{\mathrm{ed}}=$

- Go to "time span" and enter 2010 to 2016.

- I searched for the following search string: [Brazilian Amazon AND deforestation OR protected OR forest OR conservation OR governance]

- I also searched for [Soy Moratorium] using a separate search.

- The first search yielded more than one million articles.

- A search in the title yielded 253,810 articles.

- I therefore decided to limit my search in this database to the search string of "Brazilian Amazon AND deforestation," which yielded 185 articles (Table 25).

- The separate search for "Soy Moratorium," yielded 3 articles.

Table 35 lists the detailed search results. 
Table 35. Keyword Search Results

\begin{tabular}{|l|l|l|}
\hline Database & Keywords & Articles \\
\hline Web of Science & $\begin{array}{l}\text { Brazilian Amazon AND deforestation OR } \\
\text { protected OR forest OR conservation OR } \\
\text { governance }\end{array}$ & $1,010,918$ \\
\hline Web of Science & $\begin{array}{l}\text { Title search: Brazilian Amazon AND } \\
\text { deforestation OR protected OR forest OR } \\
\text { conservation OR governance }\end{array}$ & 253,810 \\
\hline Web of Science & $\begin{array}{l}\text { Title search: Brazilian Amazon AND } \\
\text { deforestation }\end{array}$ & 185 \\
\hline Web of Science & In title search: Soy Moratorium & 3 \\
\hline
\end{tabular}

Source: Own table

I reviewed title and abstract for the 185 articles and the 3 articles resulting from the Soy Moratorium search. Based on the title and abstract review, I considered 14 articles as a close match.

I reviewed more closely the following 15 studies that had a promising title and abstract.

1. Börner, J., Kis-Katos, K., Hargrave, J., and König, K. 2015. Post-Crackdown Effectiveness of Field-Based Forest Law Enforcement in the Brazilian Amazon. PLoS ONE 10(4): e0121544. oi:10.1371/journal.pone.0121544.

2. Börner, J., Marinho, E., and Wunder, S. 2015. "Mixing Carrots and Sticks to Conserve Forests in the Brazilian Amazon: A Spatial Probabilistic Modeling Approach.” Ed. Chris T. Bauch. Plos One 10.2 (2015): e0116846.

3. Börner, J., Wunder, S., Wertz-Kanounnikoff, S., Hyman, G., \& Nascimento, N. 2014. Forest law enforcement in the Brazilian Amazon: Costs and income effects. Global Environmental Change 29, 294-305. https://doi.org/10.1016/J.GLOENVCHA. 2014.04.021.

4. Cisneros, E., Zhou, S. L., and Börner, J. 2015. Naming and Shaming for Conservation: Evidence from the Brazilian Amazon. Plos One 10(9): e0136402. doi:10.1371/ journal.pone.0136402. 
5. Dias, L. F. O., Dias, D. V., and Magnusson, W. E. 2015. Influence of Environmental Governance on Deforestation in Municipalities of the Brazilian Amazon. PLOS ONE, 10(7), e0131425. https://doi.org/10.1371/journal.pone.0131425.

6. Hargrave, J., and Kis-Katos, K. 2013. Economic Causes of Deforestation in the Brazilian Amazon: A Panel Data Analysis for the 2000s. Environmental and Resource Economics 54(4), 471-494. https://doi.org/10.1007/s10640-012-9610-2.

7. L'Roe, J., Rausch, L., Munger, J., and Gibbs, H.K. 2016. Mapping properties to monitor forests: Landholder response to a large environmental registration program in the Brazilian Amazon. Land Use Policy 57, pages 193-203.

8. Moutinho, P., Guerra, R., and Azevedo-Ramos, C. 2016. Achieving zero deforestation in the Brazilian Amazon: What is missing? Elementa: Science of the Anthropocene, 4(0), 000125. https://doi.org/10.12952/journal.elementa.000125.

9. Nolte, C., Agrawal, A., Silvius, K. M., and Soares-Filho, B. S. 2013. Governance regime and location influence avoided deforestation success of protected areas in the Brazilian Amazon. Proceedings of the National Academy of Sciences of the United States of America, 110(13), 4956-4961. https://doi.org/10.1073/pnas.1214786110.

10. Pfaff, A., Robalino, J., Herrera, D., and Sandoval, C. 2015. Protected Areas' Impacts on Brazilian Amazon Deforestation: Examining Conservation - Development Interactions to Inform Planning. PLOS ONE, 10(7), e0129460. https://doi.org/10.1371/journal.pone.0129460.

11. Rudorff, B. F. T., Adami, M., Aguiar, D. A., Moreira, M. A., Mello, M. P., Fabiani, L., ... and Pires, B. M. 2011. The Soy Moratorium in the Amazon Biome Monitored by Remote Sensing Images. Remote Sensing 3(1), 185-202. https://doi.org/10.3390/ rs3010185.

12. Sousa, P., and Queiroz, P. 2016. Decreasing Deforestation in the Southern Brazilian Amazon-The Role of Administrative Sanctions in Mato Grosso State. Forests 7(12): 66. https://doi.org/10.3390/f7030066.

13. Soares-Filho, B., Moutinho, P., Nepstad, D., Anderson, A., Rodrigues, H., Garcia, R., ... and Maretti, C. 2010. Role of Brazilian Amazon protected areas in climate change 
mitigation. Proceedings of the National Academy of Sciences of the United States of America, 107(24), 10821-10826. https://doi.org/10.1073/pnas.0913048107.

14. Tritsch, I., and Arvor, D. 2016. Transition in environmental governance in the Brazilian Amazon: emergence of a new pattern of socio-economic development and deforestation. Land Use Policy 59: 446-455. https://doi.org/10.1016/ J.LANDUSEPOL.2016.09.018.

Following a more detailed review, I excluded nine studies that did not meet my selection criteria.

With respect to the Soy Moratorium, I found the following three papers, which I reviewed:

1) Gibbs, H., Rausch, L., Munger, J., Schelly, I., Morton, D., Noojipady, P., Soares-Filho, B., Barreto, P., Micol, L., and Walker, N. 2015. "Brazil's Soy Moratorium.” Science 347(6220): 377-378.

2) Rudorff, B. F. T., Adami, M., Risso, J., de Aguiar, D. A., Pires, B., Amaral, D., ... and Cecarelli, I. (2012). Remote Sensing Images to Detect Soy Plantations in the Amazon Biome-The Soy Moratorium Initiative. Sustainability 4(5): 1074-1088. https://doi.org/10.3390/su4051074.

3) Rudorff, B. F. T., Adami, M., Aguiar, D. A., Moreira, M. A., Mello, M. P., Fabiani, L., ... and Pires, B. M. 2011. The Soy Moratorium in the Amazon Biome Monitored by Remote Sensing Images. Remote Sensing 3(1): 185-202. https://doi.org/10.3390/ $\underline{\mathrm{rs} 3010185 .}$.

After a more detailed review, I excluded all three studies, because they did not meet my selection criteria.

The final result that met my selection criteria were the following six studies:

1. Börner, J., Kis-Katos, K., Hargrave, J., and König, K. 2015. Post-Crackdown Effectiveness of Field-Based Forest Law Enforcement in the Brazilian Amazon. PLoS ONE 10(4): e0121544. oi:10.1371/journal.pone.0121544. 
2. Cisneros, E., Zhou, S.L., and Börner, J. 2015. Naming and Shaming for Conservation: Evidence from the Brazilian Amazon. Plos One 10(9): e0136402. doi:10.1371/journal.pone.0136402.

3. Hargrave, J., and Kis-Katos, K. 2013. Economic Causes of Deforestation in the Brazilian Amazon: A Panel Data Analysis for the 2000s. Environmental and Resource Economics 54(4): 471-494. https://doi.org/10.1007/s10640-012-9610-2.

4. Nolte, C., Agrawal, A., Silvius, K. M., and Soares-Filho, B. S. 2013. Governance regime and location influence avoided deforestation success of protected areas in the Brazilian Amazon. Proceedings of the National Academy of Sciences of the United States of America, 110(13), 4956-4961. https://doi.org/10.1073/pnas.1214786110.

5. Pfaff, A., Robalino, J., Herrera, D., and Sandoval, C. 2015. Protected Areas' Impacts on Brazilian Amazon Deforestation: Examining Conservation - Development Interactions to Inform Planning. PLOS ONE, 10(7), e0129460. https://doi.org/10.1371/ journal.pone.0129460.

6. Soares-Filho, B., Moutinho, P., Nepstad, D., Anderson, A., Rodrigues, H., Garcia, R., ... and Maretti, C. 2010. Role of Brazilian Amazon protected areas in climate change mitigation. Proceedings of the National Academy of Sciences of the United States of America, 107(24), 10821-10826. https://doi.org/10.1073/pnas.0913048107. 



\section{Annex C. Chapter Five}

Table 36. Environmental policies and their implementation mechanisms

\begin{tabular}{|c|c|c|}
\hline $\begin{array}{l}\text { Environmental } \\
\text { policy }\end{array}$ & Implementation mechanism & Conservation results \\
\hline Protected areas & $\begin{array}{l}\text { The government agencies' ability to } \\
\text { enforce conservation regulations }\end{array}$ & $\begin{array}{l}\text { Nolte et al. 2015: Our analysis } \\
\text { confirms that all types of protected } \\
\text { areas have contributed to avoiding } \\
\text { deforestation in the Brazilian Amazon } \\
\text { regardless of their specific } \\
\text { conservation objectives. } \\
\text { Hargrave et al. 2013: Changes in the } \\
\text { size of both protected and indigenous } \\
\text { areas are negatively related to } \\
\text { changes in deforestation. }\end{array}$ \\
\hline Blacklisting & $\begin{array}{l}\text { Reputational risk for blacklisted } \\
\text { communities and increased external } \\
\text { support (from NGOs) or pressure } \\
\text { (from IBAMA); increased } \\
\text { bureaucratic burden }\end{array}$ & $\begin{array}{l}\text { Cisneros et al. (2015): The average } \\
\text { effect of blacklisting on deforestation } \\
\text { in blacklisted districts ranges } \\
\text { between roughly } 13-36 \%[\ldots] \text {. This } \\
\text { corresponds to an absolute reduction } \\
\text { in deforestation of } 600-6,750 \mathrm{~km}^{2} \\
\left(4,022 \mathrm{~km}^{2} \text { on average) from } 2008 \text { to }\right. \\
2012\end{array}$ \\
\hline $\begin{array}{l}\text { Field-based law } \\
\text { enforcement } \\
\text { against } \\
\text { deforestation }\end{array}$ & $\begin{array}{l}\text { Field-based enforcement } \\
\text { missions; punishment includes fines, } \\
\text { embargoes, seizure and destruction } \\
\text { of production goods, tools and } \\
\text { material, and arrest, among others } \\
\text { Börner } 2015 \text { b: "Once liability is } \\
\text { established, offenders may face } \\
\text { significant disincentives in the form } \\
\text { of multiple layers of legal coercion, } \\
\text { such as confiscation of assets and } \\
\text { monetary fines or cross-compliance } \\
\text { mechanisms like conditional access } \\
\text { to credit and commercialization } \\
\text { channels" }\end{array}$ & $\begin{array}{l}\text { Assunção et al. ( } 2013 a \text { ): Increased } \\
\text { presence of police force in the } \\
\text { Amazon accounts for the } \\
\text { preservation of } 59,500 \text { square } \\
\text { kilometers of forest area from } 2007 \\
\text { through 2011. [...] One of the key } \\
\text { changes introduced by the PPCDAm } \\
\text { was the use of the Real-Time System } \\
\text { for Detection of Deforestation } \\
\text { (DETER). Developed by the National } \\
\text { Institute for Space Research (INPE), } \\
\text { DETER is a satellite-based system } \\
\text { that captures and processes } \\
\text { georeferenced imagery on forest } \\
\text { cover in } 15 \text {-day intervals. }\end{array}$ \\
\hline
\end{tabular}




\begin{tabular}{|c|c|c|}
\hline $\begin{array}{l}\text { Environmental } \\
\text { policy }\end{array}$ & Implementation mechanism & Conservation results \\
\hline & & $\begin{array}{l}\text { Börner et al. (2015b) looking at the } \\
\text { years 2009-2010: On average } \\
\text { inspections have been ineffective in } \\
\text { deterring small-scale deforestation } \\
\text { and have significantly reduced } \\
\text { absolute deforestation in only two out } \\
\text { of six states. [... ] Inspected grid cells } \\
\text { exhibit on average } 48 \text { hectares of } \\
\text { deforestation, i.e., inspections reduce } \\
\text { deforestation by } 14 \% \text { on average. }\end{array}$ \\
\hline $\begin{array}{l}\text { Rural cadaster } \\
\text { system (CAR) }\end{array}$ & $\begin{array}{l}\text { Clarifying land rights and monitoring } \\
\text { and enforcing compliance with } \\
\text { Brazil's Forest Code } \\
\text { Assunção et al. 2013a: } \\
\text { "Examples include, but are not } \\
\text { limited to, harsher and } \\
\text { georeferencing requirements } \\
\text { licensing, revision of private land } \\
\text { titles, com-promised political } \\
\text { reputation for mayors of priority } \\
\text { municipalities, and economic } \\
\text { sanctions applied by agents of the } \\
\text { commodity industry." } \\
\text { Nepstad et al. } 2014: \text { "Property-level } \\
\text { law enforcement capacity was also } \\
\text { improved in } 2009 \text { through the rural } \\
\text { environmental registry [Cadastro } \\
\text { Ambiental Rural (CAR)] in Mato } \\
\text { Grosso and Pará. It requires } \\
\text { landholders to submit their property } \\
\text { boundaries to the state } \\
\text { environmental regulatory agency } \\
\text { (SM)." }\end{array}$ & $\begin{array}{l}\text { Rajão et al. 2012: In Mato Grosso, } \\
\text { SLAPR did not contribute to the } \\
\text { reduction of illegal deforestation, but } \\
\text { facilitated an increase in the total } \\
\text { amount of deforestation by } \\
\text { authorizing legal clearings on a large } \\
\text { scale. Azevedo et al. } 2014 \text { find for the } \\
\text { years } 2008-2012 \text { that even though } \\
\text { the CAR system was successful in } \\
\text { registering } 49,669 \text { rural properties in } \\
\text { Mato Grosso and Pará, "the lack of a } \\
\text { clear effect of CAR in large properties } \\
\text { and the loss of the positive effect in } \\
\text { the last few years, indicates that this } \\
\text { success can be limited and short } \\
\text { lived." }\end{array}$ \\
\hline $\begin{array}{l}\text { Access to credit } \\
\text { restrictions by non- }\end{array}$ & $\begin{array}{l}\text { Restricting rural credit and baring } \\
\text { offenders against the Forest Code }\end{array}$ & $\begin{array}{l}\text { Assunção et al. 2013b: "In the } \\
\text { absence of Resolution 3,545, }\end{array}$ \\
\hline
\end{tabular}




\begin{tabular}{|c|c|c|}
\hline $\begin{array}{l}\text { Environmental } \\
\text { policy }\end{array}$ & Implementation mechanism & Conservation results \\
\hline $\begin{array}{l}\text { compliance with } \\
\text { the Forest Code }\end{array}$ & from accessing rural credit & $\begin{array}{l}\text { deforestation in the Amazon biome } \\
\text { would have been } 2,783 \text { square } \\
\text { kilometers greater than was actually } \\
\text { observed in the } 2009 \text { through } 2011 \\
\text { period. This is equivalent to an } \\
\text { increase of about } 18 \% \text { over observed } \\
\text { deforestation." }\end{array}$ \\
\hline Soy Moratorium & $\begin{array}{l}\text { Supply chain governance of } \\
\text { commodities: Soy Moratorium limits } \\
\text { demand from big retailers for soy to } \\
\text { crops grown on land cleared before } \\
2006 \text {; }\end{array}$ & $\begin{array}{l}\text { Gibbs et al. } 2015 \text { : "In the } 2 \text { years } \\
\text { preceding the agreement, nearly } 30 \% \\
\text { of soy expansion occurred through } \\
\text { deforestation rather than by } \\
\text { replacement of pasture or other } \\
\text { previously cleared lands. After the } \\
\text { SoyM, deforestation for soy } \\
\text { dramatically decreased, falling to only } \\
\sim 1 \% \text { of expansion in the Amazon } \\
\text { biome by } 2014 . "\end{array}$ \\
\hline
\end{tabular}

Source: Own table based on Assunção et al. 2013a, 2013b, 2014, 2015, Azevedo et al. 2014, Börner et al. (2015b), Cisneros et al. 2015, Gibbs et al. 2015, Hargrave et al. 2013, Rajão et al. 2012, Sills et al. 2015, and Nolte et al. 2015. 
Table 37. Data sources

\begin{tabular}{|c|c|c|}
\hline Variable & Year(s) & Source \\
\hline Deforestation and clouds & $\begin{array}{l}2002- \\
2012\end{array}$ & INPE-PRODES [3] \\
\hline $\begin{array}{l}\text { Municipality list and } \\
\text { borders }\end{array}$ & 2007 & IBGE [4] \\
\hline Strictly protected areas & $\begin{array}{l}2002- \\
2012\end{array}$ & IBAMA [5] \\
\hline $\begin{array}{l}\text { Sustainable use areas } \\
\text { Indigenous areas }\end{array}$ & $\begin{array}{l}2002- \\
2012 \\
2002- \\
2012\end{array}$ & $\begin{array}{l}\text { IBAMA [5] } \\
\text { IBAMA [5] }\end{array}$ \\
\hline $\begin{array}{l}\text { Field-based law } \\
\text { enforcement inspections }\end{array}$ & $\begin{array}{l}2001- \\
2010\end{array}$ & IBAMA [15] \\
\hline $\begin{array}{l}\text { Blacklist additions and } \\
\text { removals }\end{array}$ & $\begin{array}{l}2008- \\
2012\end{array}$ & $\begin{array}{l}\text { Decree } 6.321 / 2007 \text { and Provision } 28 / 2008 \text {, Provision } 102 \text {, } \\
\text { 203/2009, Provision } 66,67,68 / 2010 \text {, Provision } 138,139 \text {, } \\
\text { 175/2011, Provision } 187,322,323,324 / 2012 \text { [2] }\end{array}$ \\
\hline $\begin{array}{l}\text { Landholdings registered } \\
\text { within the Cadastro } \\
\text { Ambiental Rural (CAR) }\end{array}$ & $\begin{array}{l}2002- \\
2012\end{array}$ & $\begin{array}{l}\text { (Elias) Database provided by the Amazon } \\
\text { Environmental Research Institute (IPAM) in October } \\
2013\end{array}$ \\
\hline Rural credit & $\begin{array}{l}2002- \\
2012\end{array}$ & $\mathrm{BCB}[16]$ \\
\hline Soy-suitable area & $\begin{array}{l}2002- \\
2012\end{array}$ & (Britaldo) IBGE-PAM [9] \\
\hline IPCA price deflator & $\begin{array}{l}2002- \\
2012\end{array}$ & IBGE [8] \\
\hline GDP & $\begin{array}{l}2002- \\
2011\end{array}$ & (Britaldo) IBGE [11] \\
\hline Population & 2007 & (Britaldo) IBGE Demographic Census[13] \\
\hline Rainfall & & (Britaldo) \\
\hline Dry season rainfall & & (Elias) \\
\hline $\begin{array}{l}\text { World market price for } \\
\text { export products normalized } \\
\text { by fuel price }\end{array}$ & & (Elias) \\
\hline
\end{tabular}


Table 38. Summary statistics

\begin{tabular}{|c|c|c|c|c|c|}
\hline Variable & Obs & Mean & Std. Dev. & Min & Max \\
\hline municip_geocode_id & 5,230 & 2235252 & 1419261 & 1100015 & 5108956 \\
\hline year & 5,230 & 2007.5 & 2.872556 & 2003 & 2012 \\
\hline def_area & 5,230 & $2.28 \mathrm{E}+07$ & $5.90 \mathrm{E}+07$ & 0 & $1.24 \mathrm{E}+09$ \\
\hline In_def_area & 5,230 & 14.98417 & 3.133699 & 0 & 20.93595 \\
\hline cloud_error & 5,230 & 0.092539 & 0.1819949 & 0 & 1 \\
\hline cloud_error_1 & 5,230 & 0.0897674 & 0.1809785 & 0 & 1 \\
\hline temp_mean & 5,230 & 26.17447 & 1.163565 & 19.36656 & 28.90281 \\
\hline prec_mean & 5,230 & 158.6513 & 44.50801 & 51.57083 & 314.4444 \\
\hline settle_area & 5,230 & $9.05 E+08$ & $2.22 \mathrm{E}+09$ & 0 & $2.71 \mathrm{E}+10$ \\
\hline In_settlment_area & 5,230 & 16.38111 & 7.083385 & 0 & 24.02317 \\
\hline In_settlement_area_1 & 5,230 & 16.10212 & 7.28136 & 0 & 24.02317 \\
\hline forest_price & 5,230 & 436.7474 & 418.6071 & 0 & 2146 \\
\hline In_forest_price & 5,230 & 5.144407 & 2.049315 & 0 & 7.671827 \\
\hline In_forest_price_I1 & 5,230 & 5.021285 & 2.015526 & 0 & 7.53583 \\
\hline soy_price & 5,230 & 0.1413206 & 0.289955 & 0 & 1.993368 \\
\hline In_soy_price & 5,230 & 0.1065037 & 0.2139998 & 0 & 1.096399 \\
\hline In_soy_price_I1 & 5,230 & 0.1016279 & 0.2089801 & 0 & 1.096399 \\
\hline timber_price & 5,230 & 92.50912 & 92.54885 & 0 & 959.9781 \\
\hline In_timber_price & 5,230 & 3.345522 & 2.174727 & 0 & 6.867952 \\
\hline In_timber_price_I1 & 5,230 & 3.358671 & 2.146624 & 0 & 6.867952 \\
\hline cattle_heads & 5,230 & 111.5716 & 159.764 & 0 & 2143.76 \\
\hline In_cattle_heads & 5,230 & 3.730504 & 1.633321 & 0 & 7.670783 \\
\hline In_cattle_heads_I1 & 5,230 & 3.699805 & 1.625933 & 0 & 7.65099 \\
\hline gdppc & 5,230 & 8.619138 & 8.910998 & 1.459072 & 144.5496 \\
\hline gdppc_I1 & 5,230 & 7.942336 & 7.906508 & 1.450794 & 144.4961 \\
\hline In_gdppc_I1 & 5,230 & 1.823924 & 0.6530296 & 0.372111 & 4.973252 \\
\hline gdpagrpc & 5,230 & 2.276723 & 9.038774 & 0.0003693 & 197.8719 \\
\hline gdpagrpc_I1 & 5,230 & 2.078592 & 8.255747 & 0.0003693 & 177.1954 \\
\hline In_gdpagrpc_I1 & 5,230 & 0.6073509 & 0.7048648 & 0.0003692 & 5.18288 \\
\hline dist_capital & 5,230 & 1487099 & 501694.7 & 369944.5 & 2872215 \\
\hline In_dist_capital & 5,230 & 14.15319 & 0.3533901 & 12.82111 & 14.87059 \\
\hline forest_parea2002 & 5,230 & 0.4540284 & 0.300898 & 0.0514707 & 0.9898914 \\
\hline pop_density2000 & 5,230 & 17.38333 & 68.40411 & 0.130715 & 1225.586 \\
\hline farms_share_without_title & 5,230 & 0.3806159 & 0.1728227 & 0.0157116 & 0.9526138 \\
\hline ind_parea & 5,230 & 0.0820667 & 0.1677785 & 0 & 0.9803586 \\
\hline upi_parea & 5,230 & 0.0314683 & 0.0931408 & 0 & 0.551165 \\
\hline
\end{tabular}




\begin{tabular}{|l|l|r|r|r|r|}
\hline Variable & Obs & Mean & \multicolumn{1}{c|}{ Std. Dev. } & Min & \multicolumn{1}{c|}{ Max } \\
\hline uus_parea & 5,230 & 0.1061223 & 0.2219984 & 0 & 0.9880715 \\
\hline nibamafines_no & 5,230 & 14.1761 & 27.99008 & 0 & 351 \\
\hline emb_cont & 5,230 & 0.0386233 & 0.192714 & 0 & 1 \\
\hline car_area & 5,230 & $2.69 \mathrm{E}+08$ & $1.06 \mathrm{E}+09$ & 0 & $2.40 \mathrm{E}+10$ \\
\hline credit_total & 5,230 & $1.13 \mathrm{E}+07$ & $2.51 \mathrm{E}+07$ & 0 & $4.23 \mathrm{E}+08$ \\
\hline municip_amzbiome & 5,230 & 0.8527725 & 0.3543665 & 0 & 1 \\
\hline
\end{tabular}

We used panel data for 523 municipalities over 10 years, which correspond to 5,230 observations. All area measurements and the distance to the capital are provided in sqm (for now). Prices are provided in Brazilian Reis. The remainder of the variables are numbers, such as total number of credits, number of fines, number of cattle heads, or share of farms without a title per municipality.

\section{Table 39. Basic modeling results}

\begin{tabular}{|c|c|c|c|c|c|c|c|c|c|c|}
\hline & R & $\mathbf{0}$ & fa & 65 & 66 & $\mathbf{R}$ & B & IA & 5 & 6 \\
\hline clood_enter_II & $\begin{array}{l}-1.472+\cdots 6 \\
(0.385)\end{array}$ & $\begin{array}{l}-1.4790 * 0 \\
(0.386)\end{array}$ & $\begin{array}{l}-1,469+6 t \\
(0.386)\end{array}$ & $\begin{array}{l}+1.479 \times 1 . \\
(0.380)\end{array}$ & $\begin{array}{l}-0,321 \cdots \\
(0,148)\end{array}$ & $\begin{array}{l}-0.912 * \cdots \\
(0.297)\end{array}$ & $\begin{array}{l}+0.9060 * 0 \\
(0.297)\end{array}$ & $\begin{array}{l}-0.784 * \ldots+ \\
(0.291)\end{array}$ & $\begin{array}{l}-0.784 * \cdots \\
(0.291)\end{array}$ & $\begin{array}{l}0,038 \\
(0,168)\end{array}$ \\
\hline clowd_crien & $\begin{array}{l}-1.535 \cdots \\
(0230)\end{array}$ & $\begin{array}{l}+1526=60 \\
(0.220)\end{array}$ & $\begin{array}{l}-1.522+\cdots \\
(0.219)\end{array}$ & $\begin{array}{l}-1.513 \cdots \\
(0.223)\end{array}$ & $\begin{array}{l}-0.521 \cdots \cdots \\
(0.202)\end{array}$ & $\begin{array}{l}-0.245 \\
(0.2 \times 5)\end{array}$ & $\begin{array}{l}-0.213 \\
(0.257)\end{array}$ & $\begin{array}{l}-0.176 \\
(0.2 \times 3)\end{array}$ & $\begin{array}{l}-0.176 \\
(0.2 \times 3)\end{array}$ & $\begin{array}{l}-0.059 \\
(0.174)\end{array}$ \\
\hline tcasp_mian & & $\begin{array}{l}0.045 \\
(0.105)\end{array}$ & $\begin{array}{l}0.028 \\
(0.104)\end{array}$ & $\begin{array}{l}0.032 \\
(0.103)\end{array}$ & $\begin{array}{l}0.024 \\
(0.097)\end{array}$ & & $\begin{array}{l}0.189 \\
(0.120)\end{array}$ & $\begin{array}{l}0.071 \\
(0.123)\end{array}$ & $\begin{array}{l}0.071 \\
60.123)\end{array}$ & $\begin{array}{l}0.059 \\
(0,100)\end{array}$ \\
\hline $\mathrm{xw}_{\text {_mean }}$ & & $\begin{array}{l}0.002 * \\
(0.001)\end{array}$ & $\begin{array}{l}0.002 \cdot \\
(0.001)\end{array}$ & $\begin{array}{l}0.002 * \\
(0.001)\end{array}$ & $\begin{array}{l}0.000 \\
(0.001)\end{array}$ & & $\begin{array}{l}0.000) \\
(0.002)\end{array}$ & $\begin{array}{l}0.003 \cdot \\
(0.002)\end{array}$ & $\begin{array}{l}a(0)= \\
(0.002)\end{array}$ & $\begin{array}{l}0.000 \\
(0.001)\end{array}$ \\
\hline In_sertile_area_II & & & $\begin{array}{l}-0.002 \\
(0.008)\end{array}$ & $\begin{array}{l}.0006 \\
(0.000)\end{array}$ & $\begin{array}{l}0.010 \\
(0.007)\end{array}$ & & & $\begin{array}{l}0.027+\cdots \\
(0.009)\end{array}$ & $\begin{array}{l}0.027+*+ \\
(0.00 \%)\end{array}$ & $\begin{array}{l}0.006 \\
(0.008)\end{array}$ \\
\hline In_forest_peice JII & & & $\begin{array}{l}0.328 \% \\
(0.137)\end{array}$ & $\begin{array}{l}0.314 * * \\
(0.138)\end{array}$ & $\begin{array}{l}0.113 \\
(0.102)\end{array}$ & & & $\begin{array}{l}0.481 \cdots \cdots \\
(0.132)\end{array}$ & $\begin{array}{l}0.081+\cdots \\
(0.132)\end{array}$ & $\begin{array}{l}0.006 \\
(0.081)\end{array}$ \\
\hline In_woy_orice_11 & & & $\begin{array}{l}-0.210 \\
(0.176)\end{array}$ & $\begin{array}{l}-0.196 \\
(0.177)\end{array}$ & $\begin{array}{l}-0.057 \\
(0.167)\end{array}$ & & & $\begin{array}{l}0.517 * * \\
(0.243)\end{array}$ & $\begin{array}{l}\text { e.s17*t } \\
(0.243)\end{array}$ & $\begin{array}{l}0.479 * * \\
(0.217)\end{array}$ \\
\hline In_timber_yrice_II & & & $\begin{array}{l}-0.037 \\
(0.025)\end{array}$ & $\begin{array}{l}+0.046 * \\
(0.025)\end{array}$ & $\begin{array}{l}-0.021 \\
(0.021)\end{array}$ & & & $\begin{array}{l}\text { a.c5s. } \\
(0.039)\end{array}$ & $\begin{array}{l}0065= \\
\text { (0.039) }\end{array}$ & $\begin{array}{l}0.048 \\
(0.030)\end{array}$ \\
\hline In_cattle_bends_II & & & $\begin{array}{l}-0.159 \\
(0.159)\end{array}$ & $\begin{array}{l}-0.196 \\
(0.159)\end{array}$ & $\begin{array}{l}-0.214 \\
(0.136)\end{array}$ & & & $\begin{array}{l}0.262 * * \\
(0.125)\end{array}$ & $\begin{array}{l}0.262 * \\
(0.125)\end{array}$ & $\begin{array}{l}0.010 \\
(0.004)\end{array}$ \\
\hline In_edpogre_II & & & $\begin{array}{l}0.037 \\
(0.121)\end{array}$ & $\begin{array}{l}0.041 \\
(0.120)\end{array}$ & $\begin{array}{l}-0,060) \\
(0,114)\end{array}$ & & & $\begin{array}{l}-0,062 \\
(0,166)\end{array}$ & $\begin{array}{l}-0.062 \\
(0.166)\end{array}$ & $\begin{array}{l}-0.048 \\
(0.139)\end{array}$ \\
\hline ln_edore_ll & & & $\begin{array}{l}-0.018 \\
(0.1 \times 2)\end{array}$ & $\begin{array}{l}-0.061 \\
(0.1 \times 1)\end{array}$ & $\begin{array}{l}0.065 \\
(0.157)\end{array}$ & & & $\begin{array}{l}0.383+4 \\
(0.184)\end{array}$ & $\begin{array}{l}0.353 *+ \\
(0.184)\end{array}$ & $\begin{array}{l}0.232 \\
(0.151)\end{array}$ \\
\hline ycar_x_In_dist_capital & & & & $\begin{array}{l}0.116 * 0 \\
(0.091)\end{array}$ & $\begin{array}{l}-0.062 \\
(0.050)\end{array}$ & & & & & \\
\hline year_x_furm,_parea?002 & & & & $\begin{array}{l}0.463 * \cdots \\
(0.064)\end{array}$ & $\begin{array}{l}0.228 \cdots \\
(0.053)\end{array}$ & & & & & \\
\hline ycar_x_pop_dcnaity2000 & & & & $\begin{array}{l}0.000 \\
\{0.000\}\end{array}$ & $\begin{array}{l}0.000 * * \\
(0.000)\end{array}$ & & & & & \\
\hline year_x_farme_share_withoot_. & & & & $0.240 * 64$ & 0.132 & & & & & \\
\hline nbb_In_def_arca & & & & $(0.0 \times 3)$ & $\begin{array}{l}(0,067) \\
0.837 * \cdots \\
(0.061)\end{array}$ & & & & & $\begin{array}{l}0.918 \ldots \ldots \\
(0.058)\end{array}$ \\
\hline Rit & 0.077 & 0.077 & 0.079 & $0.0 \times 3$ & 0.395 & 0.172 & 0.173 & 0.183 & 0.183 & 0.548 \\
\hline Acj, $\mathrm{R}:$ & 0.075 & 0.075 & 0.075 & 0.079 & 0.392 & 0.078 & 0.079 & 0.089 & 0.069 & 0.496 \\
\hline Num, obs: & 4707 & 4707 & 4707 & 4707 & 4707 & 5230 & 5230 & 5230 & 5230 & 5230 \\
\hline
\end{tabular}


Columns (1) and (2) refer to Least-Squares (LS) First Difference (FD) and Fixed Effects (FE) estimations. Column (3) shows the result of a FE regression using a spatial error model estimated by Maximum-Likelihood (ML). Column (4) shows the result of a FE regression using a spatial auto-correlation model (SAC) estimated by Maximum-Likelihood (ML). Column (5) and (6) show results of a general moments (GM) estimation of FE SEM and FE SAC models. ${ }^{96}$ As a prospect of future analysis, results in Column 6 take spatial auto-correlation into account.

\footnotetext{
${ }^{96}$ Spatial Hausmann tests for random versus fixed effects using the four models (1-2) resulted in Chi-sq. (p-value) statistics: Results consistently indicate to non-zero correlations of the unobserved individual fixed component with the explanatory variables, suggesting the use of FE vs. Random effects estimations (Mutl and Pfaffermayr 2011). A Conditional Lagrage Multiplier (CLM) test for spatial auto-correlation developed by Baltagi et al. (2003) by has the LM-lambda statistic (p-value ): rejecting the Null-hypothesis of no spatial auto-correlation in the errors.
} 
Table 40. Modeling results for the eight environmental policies

\begin{tabular}{|c|c|c|c|c|c|c|}
\hline & LS FD & LS FE & $\begin{array}{l}\text { ML FE } \\
\text { SEM }\end{array}$ & $\begin{array}{l}\text { MLFE } \\
\text { SAC }\end{array}$ & $\begin{array}{l}\text { GM FE } \\
\text { SEM }\end{array}$ & $\begin{array}{l}\text { GM FE } \\
\text { SAC }\end{array}$ \\
\hline cloud_etror_II & $\begin{array}{l}-1,487 * * \bullet \\
(0.393)\end{array}$ & $\begin{array}{l}-0.774 * * \\
(0.325)\end{array}$ & $\begin{array}{l}-0.632 \cdots \\
(0.181)\end{array}$ & $\begin{array}{l}-0,633 \cdots * \\
(0,157)\end{array}$ & $\begin{array}{l}-0.635 * \cdots \\
(0.181)\end{array}$ & $\begin{array}{l}-0.534 \cdots * \\
(0.175)\end{array}$ \\
\hline cloud_errot & $\begin{array}{l}-1.510^{* \ldots .} \\
(0.223)\end{array}$ & $\begin{array}{l}-0.284 \\
(0.239)\end{array}$ & $\begin{array}{l}-0.416 * * \\
(0.181)\end{array}$ & $\begin{array}{l}-0.198 \\
(0.154)\end{array}$ & $\begin{array}{l}-0.412 * * \\
(0.182)\end{array}$ & $\begin{array}{l}-0.247 \\
(0.165)\end{array}$ \\
\hline temp_mean & $\begin{array}{l}0.029 \\
(0.108)\end{array}$ & $\begin{array}{l}-0.210 \\
(0.138)\end{array}$ & $\begin{array}{l}-0.244 * * \\
(0.106)\end{array}$ & $\begin{array}{l}-0.134 \\
(0.087)\end{array}$ & $\begin{array}{l}-0.243 * . \\
(0.106)\end{array}$ & $\begin{array}{l}-0.137 \\
(0.093)\end{array}$ \\
\hline prec_mean & $\begin{array}{l}0.002 * \\
(0.001)\end{array}$ & $\begin{array}{l}0.002 \\
(0.001)\end{array}$ & $\begin{array}{l}0.002 \\
(0.001)\end{array}$ & $\begin{array}{l}0.001 \\
(0.001)\end{array}$ & $\begin{array}{l}0.002 \\
(0.001)\end{array}$ & $\begin{array}{l}0.001 \\
(0.001)\end{array}$ \\
\hline In_settle_area_II & $\begin{array}{l}-0.007 \\
(0.009)\end{array}$ & $\begin{array}{l}0.012 \\
(0.010)\end{array}$ & $\begin{array}{l}0.015^{*} \\
(0.009)\end{array}$ & $\begin{array}{l}0.013 \\
(0.008)\end{array}$ & $\begin{array}{l}0.015^{*} \\
(0.009)\end{array}$ & $\begin{array}{l}0.015^{\circ} \\
(0.008)\end{array}$ \\
\hline In_forest_price_11 & $\begin{array}{l}0.299 * * \\
(0.137)\end{array}$ & $\begin{array}{l}0.398 * \cdots \\
(0.126)\end{array}$ & $\begin{array}{l}0.391 * * * \\
(0.089)\end{array}$ & $\begin{array}{l}0.359 * * * \\
(0.077)\end{array}$ & $\begin{array}{l}0.392 * * * \\
(0.089)\end{array}$ & $\begin{array}{l}0.354 * * * \\
(0.082)\end{array}$ \\
\hline In_soy_price_11 & $\begin{array}{l}-0.197 \\
(0.177)\end{array}$ & $\begin{array}{l}0.553 * * \\
(0.236)\end{array}$ & $\begin{array}{l}0.497 * * \\
(0.243)\end{array}$ & $\begin{array}{l}0.340 \\
(0.211)\end{array}$ & $\begin{array}{l}0.499 * * \\
(0.244)\end{array}$ & $\begin{array}{l}0.271 \\
(0.228)\end{array}$ \\
\hline In_timber_price_II & $\begin{array}{l}-0.047 * \\
(0.025)\end{array}$ & $\begin{array}{l}0.070^{*} \\
(0.038)\end{array}$ & $\begin{array}{l}0.072 * * \\
(0.026)\end{array}$ & $\begin{array}{l}0.054 * * \\
(0.024)\end{array}$ & $\begin{array}{l}0.072 * \cdots \\
(0.027)\end{array}$ & $\begin{array}{l}0.053 *: \\
(0.025)\end{array}$ \\
\hline In_cattle_heads_II & $\begin{array}{l}-0.168 \\
(0.160)\end{array}$ & $\begin{array}{l}0.252 * * \\
(0.122)\end{array}$ & $\begin{array}{l}0.262 * * \\
(0.109)\end{array}$ & $\begin{array}{l}0.230 * * \\
(0.097)\end{array}$ & $\begin{array}{l}0.262 * * \\
(0.109)\end{array}$ & $\begin{array}{l}0.238 * * \\
(0.104)\end{array}$ \\
\hline In_gdpagrpe_11 & $\begin{array}{l}0.015 \\
(0.120)\end{array}$ & $\begin{array}{l}0.074 \\
(0.165)\end{array}$ & $\begin{array}{l}0.010 \\
(0.149)\end{array}$ & $\begin{array}{l}0.134 \\
(0.126)\end{array}$ & $\begin{array}{l}0.012 \\
(0.149)\end{array}$ & $\begin{array}{l}0.116 \\
(0.135)\end{array}$ \\
\hline In_gdppe_11 & $\begin{array}{l}-0.042 \\
(0.180)\end{array}$ & $\begin{array}{l}0.197 \\
(0.192)\end{array}$ & $\begin{array}{l}0.281 \\
(0.182)\end{array}$ & $\begin{array}{l}0.094 \\
(0.163)\end{array}$ & $\begin{array}{l}0.279 \\
(0.183)\end{array}$ & $\begin{array}{l}0.128 \\
(0.174)\end{array}$ \\
\hline year_x_ln_dist_capital & $\begin{array}{l}-0.124 * * \\
(0.059)\end{array}$ & & & & & \\
\hline year_x_forest_parea2002 & $\begin{array}{l}0.500 * * * \\
(0.064)\end{array}$ & & & & & \\
\hline year_x_pop_density 2000 & $\begin{array}{l}0.000 \\
(0.000)\end{array}$ & & & & & \\
\hline year_x_farms_share_without_title & $\begin{array}{l}0.218 * * \\
(0.085)\end{array}$ & & & & & \\
\hline ind_parea_11 & $\begin{array}{l}-0.086 \\
(0.256)\end{array}$ & $\begin{array}{l}-0.864 \\
(1.397)\end{array}$ & $\begin{array}{l}-1.113 * * \\
(0.512)\end{array}$ & $\begin{array}{l}-0.790^{*} \\
(0.459)\end{array}$ & $\begin{array}{l}-1.108 * * \\
(0.513)\end{array}$ & $\begin{array}{l}-0.963^{*} \\
(0.494)\end{array}$ \\
\hline upi_parea_11 & $\begin{array}{l}-1.413 \cdots * \\
(0.508)\end{array}$ & $\begin{array}{l}1.754 \cdots * \\
(0.621)\end{array}$ & $\begin{array}{l}1.319 \\
(1.047)\end{array}$ & $\begin{array}{l}1.832^{\circ} \\
(0.952)\end{array}$ & $\begin{array}{l}1.330 \\
(1.051)\end{array}$ & $\begin{array}{l}1.659 \\
(1.018)\end{array}$ \\
\hline uus_parea_I1 & $\begin{array}{l}0.193 \\
(0.433)\end{array}$ & $\begin{array}{l}1.087 \ldots . . \\
(0.396)\end{array}$ & $\begin{array}{l}1.353 * * \\
(0.609)\end{array}$ & $\begin{array}{l}0.608 \\
(0.526)\end{array}$ & $\begin{array}{l}1.346 * * \\
(0.611)\end{array}$ & $\begin{array}{l}0.660 \\
(0.562)\end{array}$ \\
\hline In_nibamafines_p_forest 2002 _II & $\begin{array}{l}-1.128 * * \\
(0.551)\end{array}$ & $\begin{array}{l}0.148 \\
(1.186)\end{array}$ & $\begin{array}{l}-0.311 \\
(1.055)\end{array}$ & $\begin{array}{l}0.145 \\
(0.952)\end{array}$ & $\begin{array}{l}-0.300 \\
(1.059)\end{array}$ & $\begin{array}{l}-0.105 \\
(1.021)\end{array}$ \\
\hline emb_cont & $\begin{array}{l}-4.811 * * \\
(1.958)\end{array}$ & $\begin{array}{l}-1.079 \\
(2.159)\end{array}$ & $\begin{array}{l}-0.896 \\
(2.855)\end{array}$ & $\begin{array}{l}-2.095 \\
(2.608)\end{array}$ & $\begin{array}{l}-0.901 \\
(2.866)\end{array}$ & $\begin{array}{l}-2.250 \\
(2.781)\end{array}$ \\
\hline emb_x_ln_car_area_11 & $\begin{array}{l}0.012 \\
(0.012)\end{array}$ & $\begin{array}{l}0.029 * * \\
(0.013)\end{array}$ & $\begin{array}{l}0.029 \\
(0.018)\end{array}$ & $\begin{array}{l}0.026 \\
(0.017)\end{array}$ & $\begin{array}{l}0.029 \\
(0.018)\end{array}$ & $\begin{array}{l}0.026 \\
(0.018)\end{array}$ \\
\hline $\begin{array}{l}\text { emb_x_ln_nibamafines_. }{ }_{-} \\
\text {forest } 2002.11\end{array}$ & -6.001 & -3.246 & -13.430 & 6.574 & -13.183 & 2.630 \\
\hline emb_x_ln_credit_total 11 & $\begin{array}{l}(5.349) \\
0.252 * *\end{array}$ & $\begin{array}{l}(8.653) \\
0.057\end{array}$ & $\begin{array}{l}(15.946) \\
0.050\end{array}$ & $\begin{array}{l}(14.704) \\
0.113\end{array}$ & $\begin{array}{l}(16.007) \\
0.050\end{array}$ & $\begin{array}{l}(15.710) \\
0.123\end{array}$ \\
\hline
\end{tabular}




\begin{tabular}{|c|c|c|c|c|c|c|}
\hline & $(0.119)$ & $(0.123)$ & $(0.173)$ & $(0.158)$ & $(0.174)$ & $(0.169)$ \\
\hline \multirow[t]{2}{*}{ In_car_area_II } & -0.006 & $-0.044 * \cdots *$ & $-0.043 * * *$ & $-0.021 * \ldots$ & $-0.043 \cdots \cdots$ & $-0.016 * * *$ \\
\hline & $(0.008)$ & $(0.008)$ & $(0.006)$ & $(0.004)$ & $(0.006)$ & $(0.005)$ \\
\hline \multirow[t]{2}{*}{ In_credit_total_11 } & 0.171 & $0.221^{*}$ & $0.234 * \cdots$ & $0.184 * *$ & $0.233 \cdots$ & $0.188 \bullet \bullet \bullet$ \\
\hline & $(0.162)$ & $(0.125)$ & $(0.051)$ & $(0.044)$ & $(0.051)$ & $(0.047)$ \\
\hline \multirow[t]{2}{*}{ biome_x_ln_crodit_total_11 } & -0.171 & -0.203 & $-0.222 * * \bullet$ & $-0.169 * \cdots$ & $-0.221 * \bullet \bullet$ & $-0.176 * * *$ \\
\hline & $(0.162)$ & $(0.125)$ & $(0.053)$ & $(0.046)$ & $(0.053)$ & $(0.049)$ \\
\hline \multirow{2}{*}{$\begin{array}{l}\text { y2008_x_biome_x_In_credit_ } \\
\text { total_II }\end{array}$} & -0.010 & $-0.032 \cdot$ & $-0.031 \cdots * \bullet$ & $-0.028 \cdots$ & $-0.031 \bullet \bullet$ & $-0.027 \bullet \cdots$ \\
\hline & $(0,010)$ & $(0.017)$ & $(0.010)$ & $(0.008)$ & $(0.010)$ & $(0.008)$ \\
\hline \multirow{2}{*}{$\begin{array}{l}\text { y2007_x_biome_x_In_soja_ } \\
\text { aptidao_area }\end{array}$} & -0.003 & $-0.026 * * *$ & $-0.018 * \cdots$ & $-0.014 * \cdots$ & $-0.018 * \ldots$ & -0.008 \\
\hline & $(0.007)$ & $(0.007)$ & $(0.006)$ & $(0.005)$ & $(0.006)$ & $(0.006)$ \\
\hline \multirow[t]{2}{*}{ tho } & & & $0.253 \cdots$ & $-0.500 * \cdots$ & & \\
\hline & & & $(0.019)$ & $(0.039)$ & & \\
\hline \multirow[t]{2}{*}{ lambda } & & & & $0.605 * \cdots$ & & $0.731 * \cdots$ \\
\hline & & & & $(0.024)$ & & $(0.067)$ \\
\hline $\mathrm{R} 2$ & 0.087 & 0.211 & 0.691 & 0.705 & 0.706 & -1.811 \\
\hline Adj. R2 & 0.080 & 0.117 & & & & \\
\hline Num, obs. & 4707 & 5230 & 5230 & 5230 & 5230 & 5230 \\
\hline$\underline{\text { Sigma2 }}$ & & & 2.883 & 2.499 & 2.903 & 276.530 \\
\hline \multicolumn{7}{|c|}{ 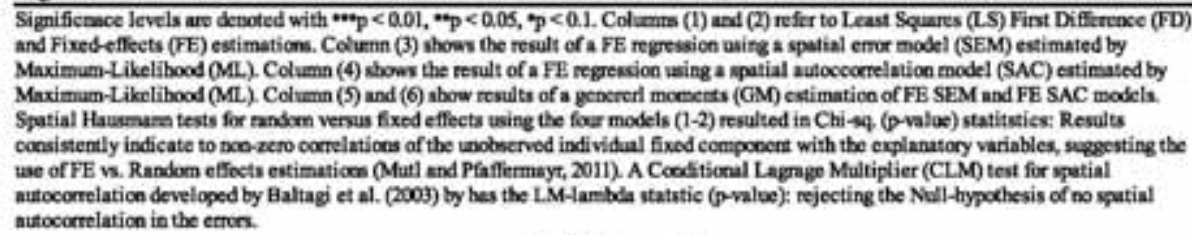 } \\
\hline
\end{tabular}

Statistical models 


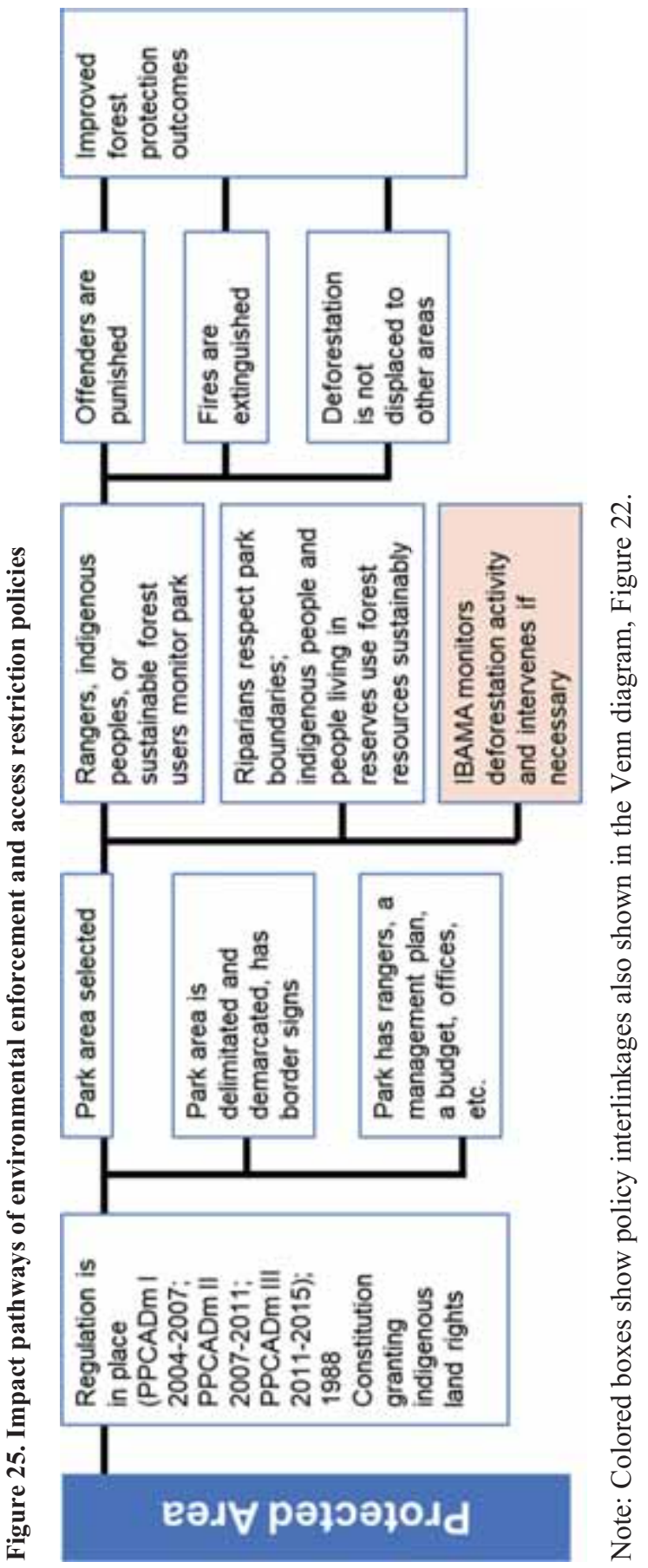




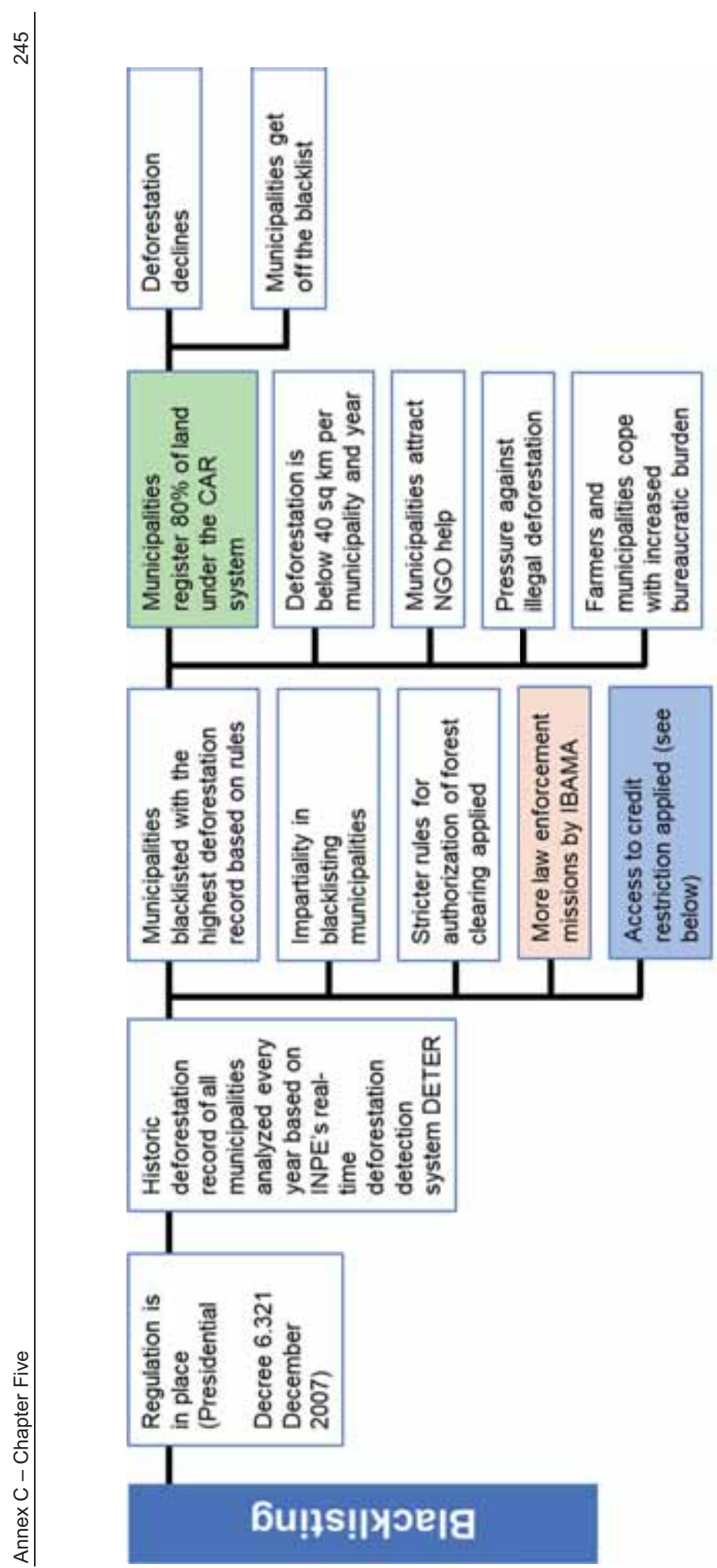




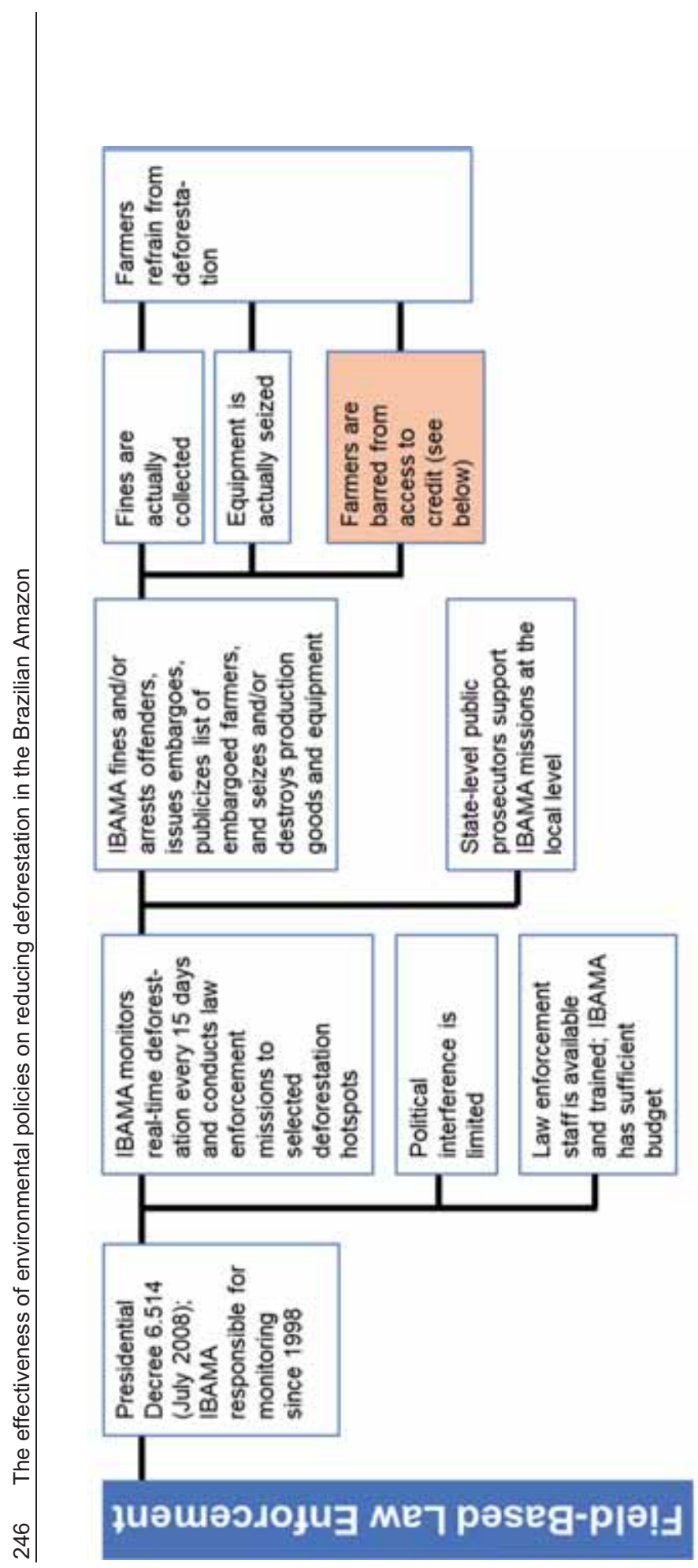




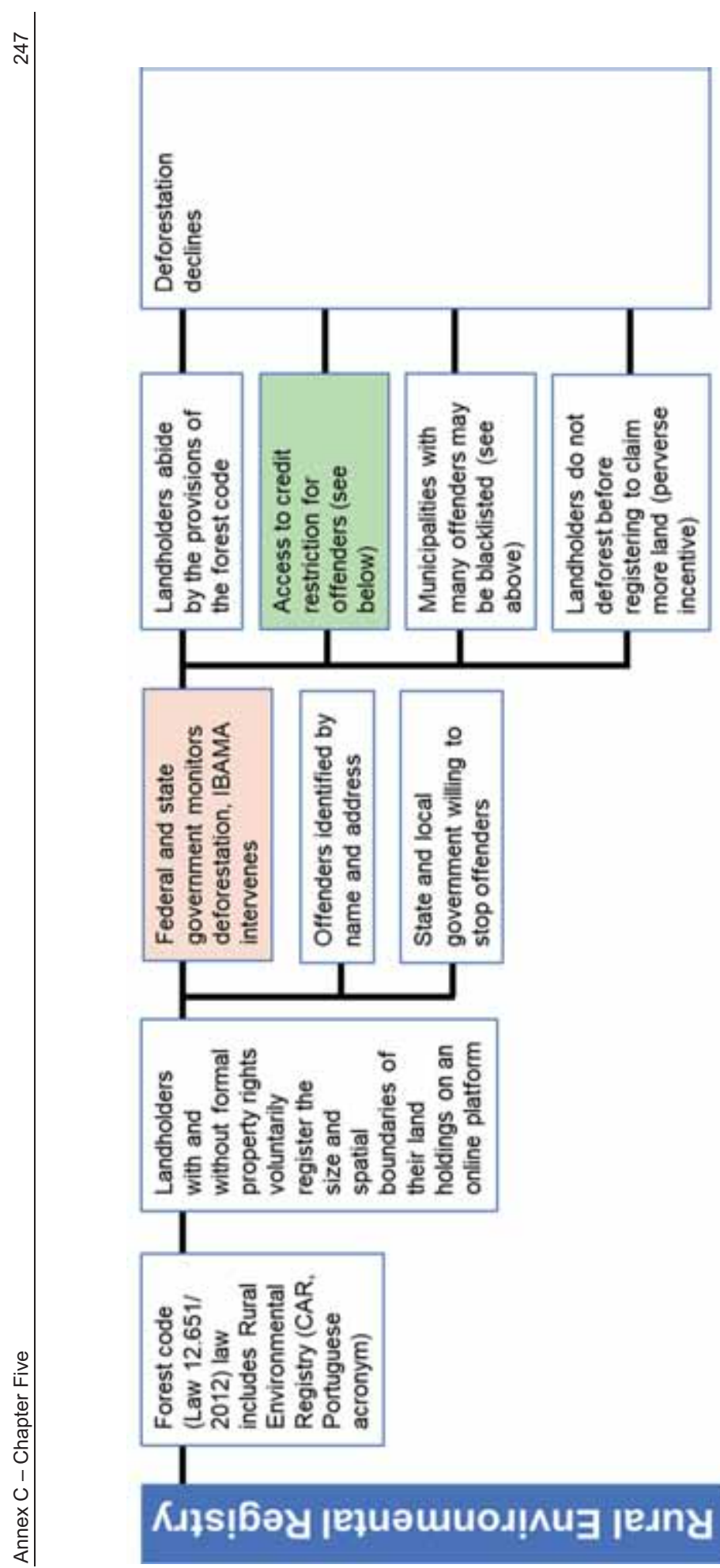




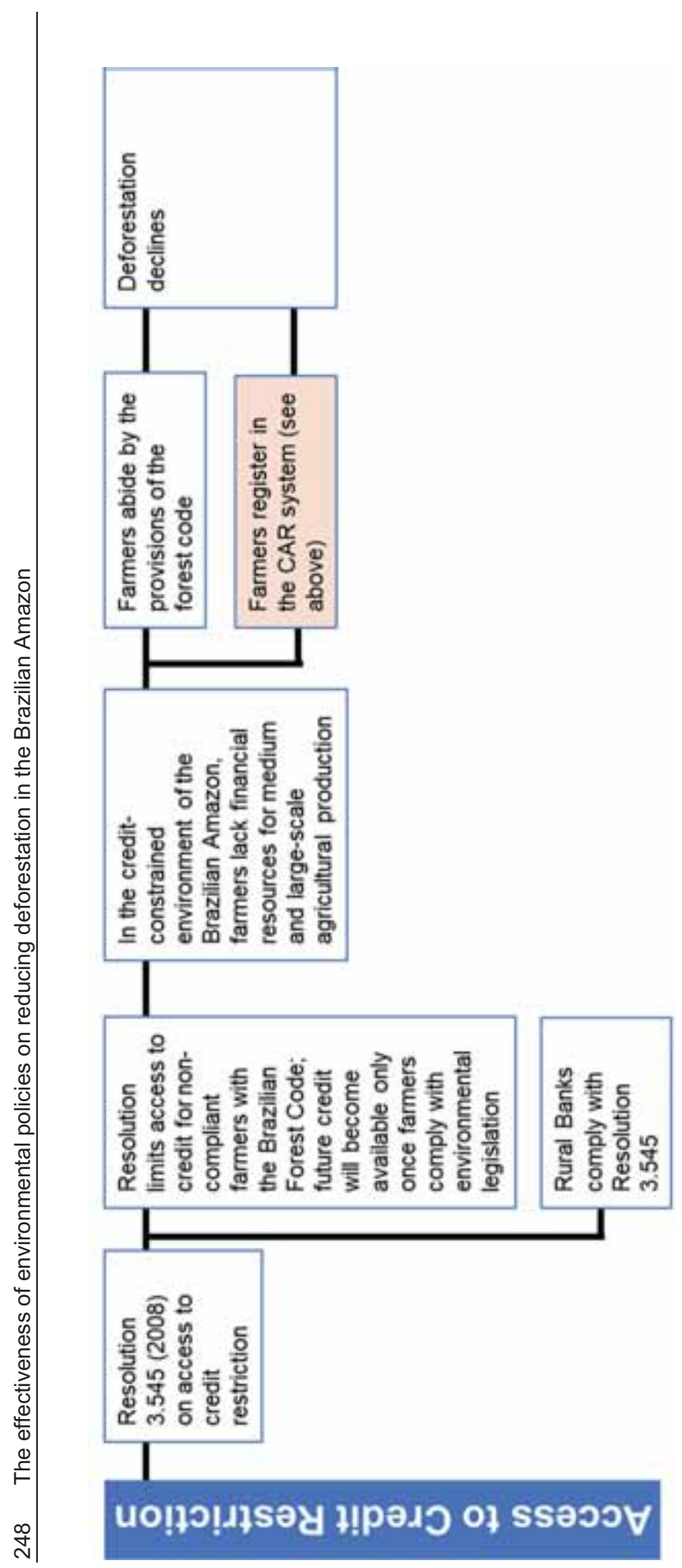




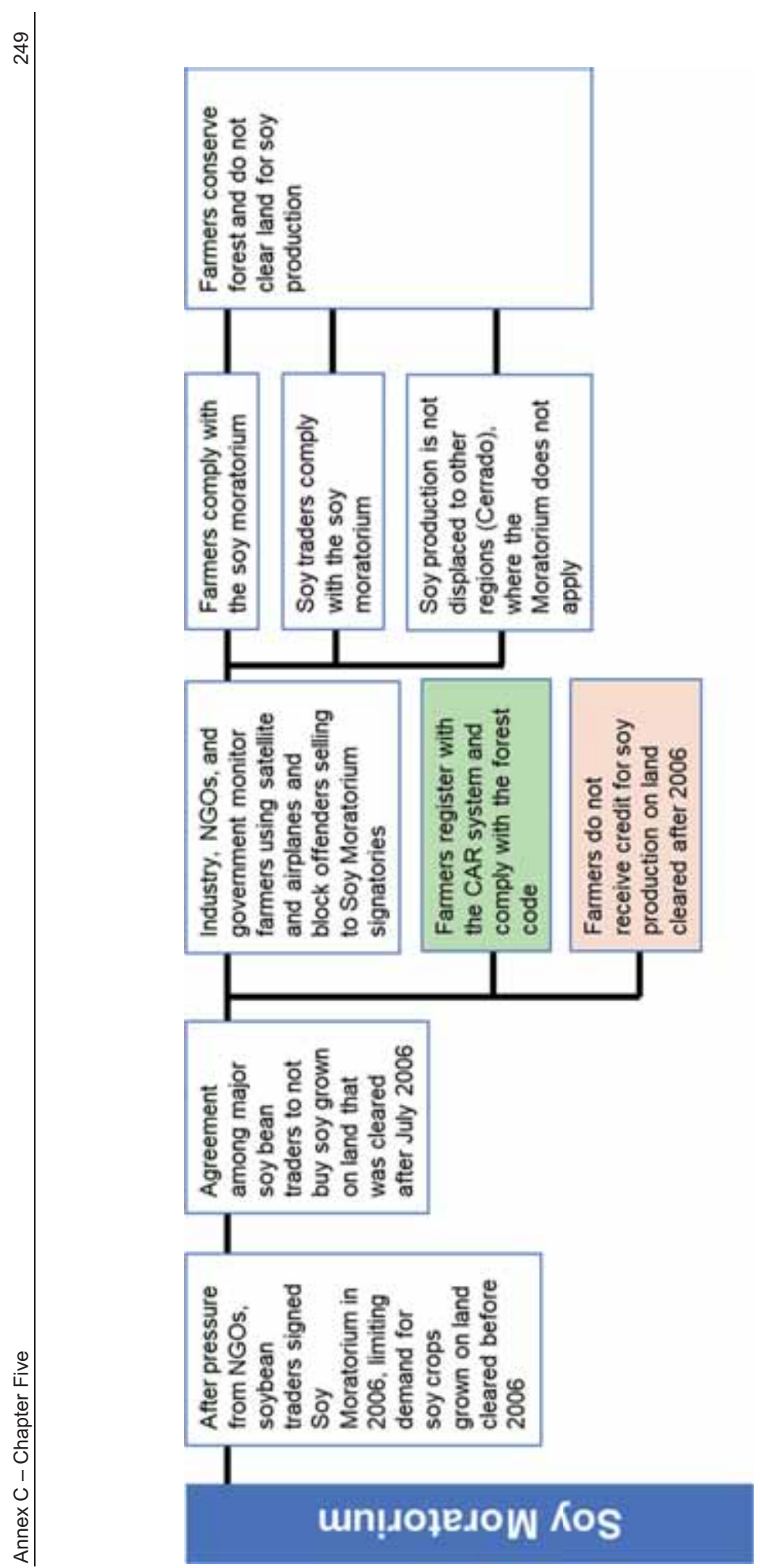




\section{Annex D. Addendum on Valorization of the Dissertation}

Following the requirements of the "Regulation governing the attainment of doctoral degrees Maastricht University 2014," 97 this addendum explains the non-academic value of this dissertation. The purpose of the addendum is to show the "process of creating value from knowledge, by making knowledge suitable and/or available for social (and/or economic) use and by making knowledge suitable for translation into competitive products, services, processes and new commercial activities." (Adapted definition based on the National Valorization Committee 2011:8). ${ }^{98}$

The valorization is arranged in five topic areas as recommended in the regulation: (1) relevance, (2) target groups, (3) activities/products, (4) innovation, and (5) schedule \& implementation.

(1) Relevance - What is the social (and/or economic) relevance of your research results (i.e., in addition to the scientific relevance)?

The topic of this dissertation is highly relevant to the future survival of our planet. Climate change threatens biodiversity and ecosystem services that are fundamental to the survival of humankind. Forests, once a reliable carbon sink, have recently become net carbon emitters. They rank second only to fossil fuels in carbon emissions. ${ }^{99}$ If we want to limit the risks of climate change by reducing carbon emissions, we must find ways to preserve forests and turn them back into net carbon sinks.

This dissertation uses the Brazilian Amazon, the world's largest stretch of tropical forest, to evaluate the effectiveness of different forest conservation policies, using a mixed methods approach.

(2) Target groups - To whom, in addition to the academic community, are your research results of interest and why?

\footnotetext{
${ }^{97} \mathrm{http} / / /$ www.promotiewijzer.nl/en/regulation-doctoral-degrees.html.

${ }^{98} \mathrm{http}: / /$ www.promotiewijzer.nl/en/regulation-doctoral-degrees.html.

${ }^{99}$ According to Pearson et al. 2017, Brazil ranks second on a worldwide comparison of carbon emissions from deforestation and forest degradation.
} 
My research addresses several audiences. It is first and foremost tailored to an academic audience. However, given that it resulted from my practical work as an evaluator at KfW Development Bank, it also has an audience of international development practitioners that negotiate environmental policies and projects with governments in developing countries and in emerging economies. Furthermore, this research is relevant to the government and environmental agencies of Brazil, as well as other countries with large tropical forests and indigenous peoples that are stewards of forest preservation. Lastly, this research is addressed to the international community at large in that it highlights what works and what does not in forest preservation, which is important for limiting carbon emissions and mitigating the effects of climate change.

(3) Activities/Products - Into which concrete products, services, processes, activities, or commercial activities will your results be translated and shaped?

My research on the Indigenous Lands Project, jointly funded by KfW Development Bank and the World Bank's Rainforest Trust Fund, is based on an ex post evaluation I conducted as a Senior Project Manager for KfW Development Bank in Frankfurt. The work involved a field trip to Brazil. An evaluation report was sent to the German Federal Ministry for Economic Cooperation and Development (BMZ) and a short version is published on KfW's website (https://www.kfw-entwicklungsbank.de/PDF/Evaluierung/Ergebnisse-undPublikationen/PDF-Dokumente-A-D_EN/Brasilien_Indianergebieten_2013_E.pdf).

Based on a collaboration between KfW Development Bank and AidData, I published a paper entitled "Indigenous land rights and deforestation: Evidence from the Brazilian Amazon," jointly with my co-authors from AidData in the peer-reviewed Journal of Environmental Economics and Management in July 2017.

In 2016, I presented the paper during the 18th Annual BIOECON Conference entitled "Instruments and Incentive Mechanisms for Biodiversity Conservation and Ecosystem Service Provision," September 14-16, 2016 at Kings College, Cambridge, U.K., and received valuable feedback.

In November 2017, I was asked to submit a chapter on the "Effectiveness of forest protection policies in the Brazilian Amazon" as part of a Springer book on "Strategies for forest conservation in South America," edited by Felix Fuder. This chapter is part of this dissertation. An extended version of chapter 6 will be published at a later time. 
(4) Innovation - To what degree can your results be called innovative in respect to the existing range of products, services, processes, activities, and commercial activities?

This research was novel in that it used impact evaluation methods to test the effectiveness of land rights for indigenous peoples and their impact on forest preservation. It triangulated the findings with field work in the state of Amazonas, something only few researchers are allowed to conduct, due to Brazil's protection of indigenous communities through FUNAI, which highly restricts access to these communities.

This research is also novel in its highlighting of the positive impact environmental policies can have on forest preservation, something that is missing from earlier econometric models that modeled deforestation using statistical methods.

(5) Schedule \& Implementation - How will this/these plan(s) for valorization be shaped? What is the schedule, are there risks involved, what market opportunities are there and what are the costs involved?

I plan to publish this research in two additional articles. The first article entitled "Effectiveness of forest protection policies in the Brazilian Amazon" will be published as part of a Springer book on "Strategies for forest conservation in South America," edited by Felix Fuder. A second article based on chapter 6 of this book will be published at a later date together with my coauthor Elias Cisneros.

Given that I currently work for the World Bank that implements projects similar to the Indigenous Lands Project and that conducts policy dialogues with developing countries and emerging economies, I will use this research in the future for my work in the field of climate change and environmental policies. 


\section{Annex E. Summary of the Thesis}

Deforestation has declined dramatically in the Brazilian Amazon over the past decade. The objective of this research was to better understand why it declined so fast. Specifically, the main research question was "What are the factors that explain the rapid annual decline in deforestation in the Brazilian Amazon since 2004?"

Four sub-questions were used to answer that question: (1) How does formalizing of land rights and monitoring support lead to improvements in indigenous peoples' livelihoods and survival in demarcated indigenous territories? (2) What has been the effect of demarcating indigenous territories on forest reservation? (3) How do environmental policies compare with each other in terms of their effect sizes? (4) To what extent can environmental policies be associated with a decrease in deforestation in the Brazilian Amazon?

Research question 1 - How does formalizing of land rights and monitoring support lead to improvements in indigenous peoples' livelihoods and survival in demarcated indigenous territories?

The research for this question aimed to get a local perception of four indigenous communities that were demarcated under the Indigenous Lands Project, jointly funded by the World Bank and KfW Development Bank.

The research was based on a field visit to four indigenous communities in the Brazilian state of Amazonas and used a qualitative case study methodology. The objective of the research was to better understand livelihood opportunities and survival strategies of indigenous peoples living in indigenous territories.

Using qualitative research methods, I found that providing indigenous peoples with rights to their lands not only improves their cultural autonomy but also supports their survival by creating livelihood opportunities. Even though poverty persists in the remote areas of indigenous territories, living conditions have improved dramatically over the past two decades. For example, at the time of my field visit the indigenous territories had access to modern amenities, such as schools, health centers, electricity, and improved sources of water. It was difficult to disentangle the effects of land demarcation from the provision of pensions, 
schooling, health services, and conditional cash transfer programs (such as Bolsa Escola followed by Bolsa Familia). However, the entire policy mix seemed to have had a positive effect on population growth, poverty alleviation, and education and health indicators - although a quantitative analysis of this policy mix is still needed.

\section{Research question 2 - What has been the effect of demarcating indigenous territories on forest preservation?}

To answer question 2, I wanted to find out whether demarcating indigenous territories had an impact on forest preservation. There is debate in the literature about whether parks with people or parks without people preserve forests best. My research weighs in on the side of parks with people and tests whether providing indigenous peoples with the right to their lands makes a difference in forest preservation.

I used a time series of satellite-based forest cover data covering three decades as well as matched samples of treated and comparison indigenous territories. The comparison revealed that there is no statistically significant effect of demarcating indigenous territories on forest preservation.

The analysis does not show an effect because most of the indigenous communities demarcated under the Indigenous Lands Project are not yet threatened by deforestation. Thus, demarcating indigenous territories may be an investment that does not show immediate results. With respect to my main research question of why deforestation declined dramatically over the past decade, this chapter does not yield an answer. Therefore, more research is needed to understand the decline.

Research question 3 - How do environmental policies compare with each other in terms of their effect sizes?

The objective of research question 3 was to compare the results from other authors in the peerreviewed literature. I compared six articles that had used some form of statistical matching analysis. I wanted to understand how the effect sizes of five environmental policies compared. For three additional environmental policies I did not find any article that used statistical matching analysis. 
To answer this sub-question, I relied on the methodology developed by Samii et al. 2014 for making the effect sizes comparable. The six papers covered the following environmental policies: (1) strictly protected areas, (2) sustainable use areas, (3) indigenous territories, (4) enforcement missions, and (5) public disclosure. All these policies apply to the Brazilian Amazon region.

The results of this research show that the average effect size was relatively small and comparable for all five environmental policies. It also shows that no single environmental policy was more effective than the others. Hence, I conclude that environmental policies tend to have a relatively small annual effect on deforestation. In terms of my main research question as to why deforestation declined dramatically over the last few decades, this research explains a small part of the observed decline.

Research question 4 - Have environmental policies become significant (negative) drivers of deforestation in the Brazilian Amazon?

Under research question 4, I identified a gap in the literature with respect to the marginal effect of environmental policies on deforestation. To answer the question, I used a model that combined proxies for eight environmental policies. The research shows that all the things we cannot measure precisely explain an important part of the decline in deforestation. These factors include macro-scale policy effects that my treatment indicators do not pick up. This also means that the research community should not ignore policies in econometric models of deforestation, which is an important statement given that few previous models have included policy variables.

This finding is a step in the direction of understanding the sudden decline in deforestation. It includes more detailed variables that model environmental policies than, for example, Assunção et al. (2015), who include land scarcity as a proxy for the effect of environmental policies on deforestation. However, the fact that my model only explains a small part of the variation in deforestation between the municipalities in the Brazilian Amazon shows that the research community is only beginning to understand the marginal effects of environmental policies. All the factors that cannot be explained vary between states and over time and therefore explain the large variation in the dependent variable of deforestation. More work is therefore required. 
When I look at my overarching research question and the sudden decline, I see that more research is needed to understand the decline. I also notice that my modeling approach only gets me so far. Either researchers need to devise new ways of modeling deforestation and environmental policies, or they need to drill down to the local level and gain a qualitative understanding of why deforestation decreased in specific locations. Testing global models against experience on the ground could help me better understand the deforestation decline. Combining qualitative and quantitative methods has the potential to solve some of the riddles that one method alone cannot solve.

In sum, this research filled an important research gap. Chapters 2 and 3 assessed the impact of the Indigenous Lands Project on community survival, livelihood opportunities, and forest preservation. It found that demarcating indigenous territories does not have a statistically significant effect on forest preservation. It also found that land titling is beneficial for the wellbeing of indigenous communities in that it creates conditions for a sustainable livelihood, security, and improved health conditions, as well as supporting circular migration, or living in between rural and urban spaces. In chapters 5 and 6, this research assessed eight environmental policies in the Brazilian Amazon and their effects on forest preservation. It confirmed the small effect size in forest conservation projects in the research conducted by other authors and assessed the cumulative effectiveness of the different environmental policies. 


\section{Annex F. Curriculum Vitae}

Silke Heuser was born on October 12, 1966, in Stuttgart, Germany. After graduating with the Abitur from Free Waldorfschool Uhlandshoehe in Stuttgart in 1986, she studied in Tübingen, Germany (bachelor's degree equivalent), and taught German to French high school students in Paris. In 1997, she completed the first state exam (master's degree equivalent) from Berlin University in French linguistics and education.

After working as a project manager for an international nongovernmental organization in Berlin that promoted quality education in developing countries, she studied International Education Policy at Harvard University in the United States, focusing on policy research, economics, and statistics, as well as qualitative and quantitative research methods. After graduating from the Harvard Graduate School of Education in 2003 with a master's in international education policy, she worked at the World Bank's Independent Evaluation Group for nine years in the field of natural disaster prevention and reconstruction, water management, and climate change. In 2011, she went to Congo, DRC, to assess the forest sector for a major World Bank-IEG evaluation of forests projects.

In 2012, she worked for the Asian Development Bank in Manila, Philippines, on an evaluation of natural disaster projects and subsequently accepted a position with KfW Development Bank in Frankfurt, Germany, where she led ex post evaluations in Bangladesh, Bolivia, Bulgaria, Burundi, El Salvador, Guatemala, Guyana, Honduras, Hungary, Indonesia, Lao Peoples Democratic Republic, Serbia, Sri Lanka, and the West Bank. One of the evaluation missions brought her to Brazil where she evaluated the Indigenous Lands Project that is an important part of this dissertation. Chapter three of this dissertation is based on a paper developed in cooperation with KfW Development Bank and AidData, in the United States. At KfW she also worked in KfW Operations Division to appraise a $€ 15$ million biodiversity conservation project in China using a mix of development and market loan instruments; she also conducted negotiations, wrote an appraisal report, and prepared loan documents for China's Finance Ministry.

While in Frankfurt, Silke started her Ph.D. Dual Career program (GPAC2) at UNU-MERIT at Maastricht University. Together with her husband, she adopted her daughter from China and 
moved back to Washington, D.C., where she co-authored the World Bank flagship report “Groundswell: Preparing for Internal Climate Migration” while finalizing her Ph.D. 


\section{Annex G. UNU-MERIT/MGSoG Dissertation Series}

2018

\section{Jennifer Waidler}

Social Assistance and Remittances and Their Role in the Fight Against Poverty

UNU-MERIT/MGSoG Dissertation Series № 211

\section{Choolwe Muzyamba}

The role of community mobilization in the promotion of maternal health of women living with HIV in Zambia

UNU-MERIT/MGSoG Dissertation Series № 210

\section{Juan Carlos A. Castillo Sánchez}

Assessing the Role of the Export Sector in Mexican Economic Development,1965-2014

UNU-MERIT/MGSoG Dissertation

Series № 209

\section{Tareq Abuelhaj}

Food Security Policy Impact Analysis: The

Econometrics of Cash and Food Assistance Cost

Effectiveness

UNU-MERIT/MGSoG Dissertation

Series № 208

\section{Marta Férnandez de Arroyabe Arranz}

Essays on MEAS and Innovation

UNU-MERIT/MGSoG Dissertation

Series № 207

\section{Clotilde Mahé}

Essays on Migration and Occupational Choice

UNU-MERIT/MGSoG Dissertation

Series № 206

\section{Simone Sasso}

Talent on the move. Essays on Human Capital, Graduate Mobility and Economic Development UNU-MERIT/MGSoG Dissertation

Series № 205

\section{Khaled Walid Rajab}

Strategic Planning under Fragility

UNU-MERIT/MGSoG Dissertation

Series № 204
Mutinta Hambayi Nseluke

A Tall Order: Improving Child Linear Growth UNU-MERIT/MGSoG Dissertation

Series № 203

Elvis Korku Avenyo

Innovations and Firm Performance

in sub-Saharan Africa: Empirical Analyses

UNU-MERIT/MGSoG Dissertation

Series № 202

\section{Ni Zhen}

Employment Dynamics, Firm Performance and Innovation Persistence in the Context of

Differentiated Innovation Types: Evidence from

Luxembourg

UNU-MERIT/MGSoG Dissertation

Series № 201

\section{Caroline Wehner}

Too Scared to Achieve: The Relation

Between Neuroticism, Conscientiousness

and Socioeconomic Outcomes

UNU-MERIT/MGSoG Dissertation

Series № 200

\section{Stefania Innocenti}

On Institutional Persistence

UNU-MERIT/MGSoG Dissertation Series № 199

\section{Hassen Abda Wako}

Economic Globalization, Institutions and

Development: Essays on Aid, Foreign Direct

Investment and Trade

UNU-MERIT/MGSoG Dissertation

Series № 198

2017

\section{Hans-Erik Edsand}

Winds of Change

UNU-MERIT/MGSoG Dissertation Series № 197

\author{
Ana Patricia Silva Vara \\ Redressing the Gender Gap \\ UNU-MERIT/MGSoG Dissertation Series № 196
}


Andrés Iván Mideros Mora

Essays on the Economic Effects of Non-contributory Social Protection

UNU-MERIT/MGSoG Dissertation Series № 195

\section{Tobias Broich}

New Actors in the Global Economy

UNU-MERIT/MGSoG Dissertation Series № 194

\section{Bernard Nikaj}

From No-government to E-government

UNU-MERIT/MGSoG Dissertation Series № 193

\section{Ali Safarnejad}

Prioritizing the HIV Response

UNU-MERIT/MGSoG Dissertation Series № 192

\section{Clovis Freire}

Diversification and Structural Economic Dynamics

UNU-MERIT/MGSoG Dissertation Series № 191

\section{Michael Verba}

Innovation and Knowledge Dynamics: Essays on the

Knowledge Economy

UNU-MERIT/MGSoG Dissertation Series № 190

\section{Pui Hang Wong}

The Hearts and Minds in Conflict and Peace: The

Economics of Counterinsurgency and the Psychology of Reconstruction

UNU-MERIT/MGSoG Dissertation Series № 189

\section{Brenda Yamba}

Schooling Despite All Odds: Evidence from Lesotho on Female Child Carers who Stayed in School

UNU-MERIT/MGSoG Dissertation Series № 188

\section{Sheng Zhong}

Moving towards An Energy Efficient Future: Essays on Energy Efficiency, Technology and Development UNU-MERIT/MGSoG Dissertation Series № 187

\section{Julieta Marotta}

Access to Justice and Legal Empowerment of Victims of Domestic Violence through Legal Organizations in the City of Buenos Aires: A Qualitative Empirical Legal Study

UNU-MERIT/MGSoG Dissertation Series, № 186

\section{Andrea Franco-Correa}

On the Measurement of Multidimensional Poverty as a Policy Tool: Empirical Applications to Chile,

Colombia, Ecuador and Peru

UNU-MERIT/MGSoG Dissertation Series, № 185

\section{6}

\section{Yesuf Awel}

Insurance for Growth: Empirical Essays on Insurance Demand and Impacts in Africa UNU-MERIT Dissertation Series, № 108

\section{Tigist Mekonnen Melesse}

Grow More Food using Fewer Resources:

Agricultural Technology Adoption and Innovation Practices for Inclusive and Sustainable Development UNU-MERIT Dissertation Series, № 107

\section{Eleni Yitbarek}

Getting Ahead or left Behind? Essays on Poverty Dynamics and Social Mobility in Africa UNU-MERIT Dissertation Series, № 106

\section{Thuy Dieu Nguyen}

Firm-Level Theory and Evidence of Corruption UNU-MERIT Dissertation Series, № 105

\section{Raquel Tsukada Lehman}

Essays on Household Production with Labor-Saving Technology

UNU-MERIT Dissertation Series, № 104

\section{Eva Barteková}

Multi-Problem Challenges for a Renewable Future: Empirical Studies on Competitive Disadvantages from Electricity Price Differentials and Mineral Supply Risk in an Open Economy

UNU-MERIT Dissertation Series, № 103

\section{Jocelyn Olivari}

Entrepreneurial Traits and Innovation: Evidence from Chile

UNU-MERIT Dissertation Series, № 102

\section{Muhammad Shafique}

Essays on the role of knowledge, RED, and

Technology-based Firms in the Evolution of Sociotechno-economic System

UNU-MERIT Dissertation Series, № 101 


\section{Serdar Türkeli}

Governance of Innovation Policy: Empirical Studies on Applied Political Economy by Multi-Methods Analysis

UNU-MERIT Dissertation Series, № 100

\section{Ayokunu Adedokun}

Pathways to Sustainable Peace building in Divided Societies: Lessons and Experiences from Mozambique MGSoG Dissertation Series, № 75

\section{Luiz Rothier Bautzer}

Organizing Concurrent Engineering through ICT Platforms

Blueprinting Product Lifecycle Management

Platforms across Disciplinary Agencies

MGSoG Dissertation Series, № 74

\section{Natalia Popova}

Migration in the Periphery of the European Union: Determinants of Successful and Sustainable Labour Market Integration of Return Migrants in Albania, Egypt, Moldova and Tunisia

MGSoG Dissertations Series, № 73

\section{Richard A. Martina}

Uncertainty and Resource Constraint in the Small Island Developing States:

Essays in Entrepreneurial Cognition

MGSoG Dissertations Series, № 72

\section{Cécile Cherrier}

The Expansion of Basic Social Protection in Lowincome Countries:

An Analysis of Foreign Aid Actors' Role in the Emergence of Social Transfers in Sub-Saharan Africa MGSoG Dissertations series, № 71

\section{Paul Caldron}

The Tacit Bargain in Short-Term Medical Missions: Why U.S. physicians go and what it costs MGSoG Dissertation Series, № 70

\section{Mahmut Kobal}

Customs \& Excellence: A Comparative Approach on Administrative and Regulatory Compliance Perspectives of the EU-Turkey Customs Union MGSoG Dissertation Series, № 69

\section{Craig Loschmann}

Essays on Conflict-related Migration and Development in the Case of Afghanistan

MGSoG Dissertations Series, № 68

\section{Andrea Milan}

Rural Livelihoods, Location and Vulnerable Environments: Approaches to Migration in Mountain areas of Latin America

MGSoG Dissertation Series, № 67

\section{Farida Lada}

On Guarding the Welfare of Clinical Trial Subjects

While Promoting Novel Drug Innovation

A Game Theoretical Approach

MGSoG Dissertation Series, № 66

\section{5}

\section{Hibret Belete Maemir}

Dissecting Aggregate Productivity: International Integration and Growth with Heterogeneous Firms UNU-MERIT Dissertation Series, № 96

\section{Giorgio Triulzi}

Looking for the Right Path: Technology Dynamics, Inventive Strategies and Catching-up in the Semiconductor Industry

UNU-MERIT Dissertation Series, № 95

\section{Abdul Baseer Qazi}

Knowledge flows and networks in the ICT sector: The case of Pakistan

UNU-MERIT Dissertation Series, № 94

\section{Ajay Thutupalli}

Technology Paradigm Shifts in Agriculture: Drivers of Sustainability and Catch up

UNU-MERIT Dissertation Series, № 93

\section{Eduardo Urias}

Improving access to HIVIAIDS treatment in Brazil: When are Compulsory Licenses effective in Price Negotiations?

UNU-MERIT Dissertation Series, № 92

\section{Francesca Guadagno}

Why have so few Countries Industrialised? UNU-MERIT Dissertation Series, № 91 


\section{Daniel Opolot}

The Evolution of Beliefs and Strategic Behaviour

UNU-MERIT Dissertation Series, № 90

\section{Alejandro Lavopa}

Structural Transformation and Economic

Development: Can Development Traps be Avoided

UNU-MERIT Dissertation Series, № 89

\section{Jinjin Zhao}

Urban water management reform: The Case of China UNU-MERIT Dissertation Series, № 88

\section{Simona Vezzoli}

Borders, Independence and Post-colonial Ties: the

Role of the State in Caribbean Migration

MGSoG Dissertation Series, № 65

\section{Silvia Consuelo Gómez Soler}

Civil Conflict and Education: How Does Exposure to Civil Conflict Affect Human Capital Accumulation? Evidence from Standardized Exit Exams in Colombia MGSoG Dissertation Series, № 64

\section{Paula Nagler}

Occupational Choice in the Developing World

MGSoG Dissertation Series, № 63

\section{Jasmin Kientzel}

Determinants of Professional Commitment to

Environmental Sustainability

MGSoG Dissertation Series, № 62

\section{Mehmet Güney Celbiş}

Regional Policies: Convergence, Trade, and the

Allocation of Public Capital

MGSoG Dissertation Series, № 61

\section{Florian Henning}

Living Up to Standard: Interoperability Governance and Standards Adoption in Government Information Networks

MGSoG Dissertation Series, № 60

\section{Niels P. Groen}

The Never-Ending Project

Understanding E-Government Project Escalation

MGSoG Dissertation Series, № 59

\section{Derek Copp}

Teacher-Based Reactivity to Provincial Large-scale Assessment in Canada

MGSoG Dissertation Series, № 58

\section{Michaella Vanore}

Family-Member Migration and the Psychosocial Health Outcomes of Children in Moldova and Georgia

MGSoG Dissertation Series, № 57

\section{Sonja Fransen}

The Economic and Social Effects of Remittances and Return Migration in Conflict-Affected Areas: The Case of Burundi

MGSoG Dissertation Series, № 56

\section{Ibrahim Khalil Conteh}

The Impact of Floods on Primary School Education in Zambia

MGSoG Dissertation Series, № 55

\section{Richard Bluhm}

Growth Dynamics and Development

Essays in Applied Econometrics and Political

Economy

MGSoG Dissertation Series, № 54

\section{Nevena P. Zhelyazkova}

Work-Family Reconciliation and Use of Parental Leave in Luxembourg: Empirical Analysis of Administrative Records

MGSoG Dissertation Series, № 53

\section{4}

\section{Dirk Crass}

The Impact of Brands on Innovation and Firm Performance: Empirical Evidence from Germany UNU-MERIT Dissertation Series, № 87

\section{Samyukta Bhupatiraju}

The Geographic Dimensions of Growth and Development

UNU-MERIT Dissertation Series, № 86

\section{François Lafond}

TheEvolution of Knowledge Systems

UNU-MERIT Dissertation Series, № 85 


\section{Annalisa Primi}

Promoting Innovation in Latin America: What Countries Have Learned (and What They Have Not) in Designing and Implementing Innovation and Intellectual Property Policies

UNU-MERIT Dissertation Series, № 84

\section{Fatoumata Lamarana Diallo}

Evaluation of Meal and Deworming Programs for Primary Schools in Rural Senegal

UNU-MERIT Dissertation Series, № 83

\section{Sachin Kumar Badkas}

Metachoice and Metadata: Innovating with Environmental Policy Analysis in Europe

MGSoG Dissertation Series, № 52

\section{Irina S. Burlacu}

An Evaluation of Tax-Benefit Systems Impact on the Welfare of Frontier Worker:

The Case of Luxembourg and Belgium

MGSoG Dissertation Series, № 51

\section{Özge Bilgili}

Simultaneity in Transnational Migration Research: Links Between Migrants' Host and Home Country Orientation

MGSoG Dissertation Series, № 50

\section{Yulia Privalova Krieger}

Reshaping the Big Agenda: Transnational Politics and Domestic ResistanceFinancial crisis and social protection reform in Bosnia and Herzegovina MGSoG Dissertation Series, № 49

\section{Marieke van Houte}

Moving Back or Moving Forward? Return migration after Conflict

MGSoG Dissertation Series, № 48

\section{Oxana Slobozhan}

Global Governance in the Management of Natural Resources: The Case of the Extractive Industries Transparency Initiative (EITI)

MGSoG Dissertation Series, № 47

\section{Luis Bernardo Mejia Guinand}

The Changing Role of the Central Planning Offices in Latin America: A Comparative Historical Analysis Perspective (1950-2013)

MGSoG Dissertation Series, № 46

\section{Cheng Boon Ong}

Ethnic Segregation in Housing, Schools and Neighbourhoods in the Netherlands

MGSoG Dissertation Series, № 45

\section{Luciana V. Cingolani}

Bureaucracies for Development: Oxymoron or Reality? Studies on State Capacity in Challenging Governance Contexts

MGSoG Dissertation Series, № 44

\section{Carlos Cadena Gaitán}

Green Politics in Latin American Cities - Sustainable Transport Agendas

MGSoG Dissertation Series, № 43

\section{Katie Kuschminder}

Female Return Migration and Reintegration

Strategies in Ethiopia

MGSoG Dissertation Series, № 42

\section{Metka Hercog}

Highly-Skilled Migration and New Destination

Countries

MGSoG Dissertation Series, № 41

\section{Margaret Agaba Rugadya}

Can Remittances Influence the Tenure and Quality of Housing in Uganda?

MGSoG Dissertation Series, № 40

\section{Ilire Agimi}

New Governance Under Limited Statehood: The Case of Local Government Reform in Kosovo

MGSoG Dissertation Series, № 39

\section{3}

\section{Anant Kamath}

Information Sharing through Informal Interaction in Low-Tech Clusters

UNU-MERIT Dissertation Series, № 82

\section{Flavia Pereira de Carvalho}

What we talk about when we talk about Brazilian Multinationals: An Investigation on Brazilian FDI, Economic Structure, Innovation and the Relationship between them

UNU-MERIT Dissertation Series, № 81 


\section{Jun Hou}

Complementarity in Innovation and Development: A

Cross-country Comparison

UNU-MERIT Dissertation Series, № 80

\section{Rufin Baghana}

Impacts of Government Incentives to RED, Innovation and Productivity:

A Microeconometric Analysis of the Québec Case UNU-MERIT Dissertation Series, № 79

\section{Lilia I. Stubrin}

High-Tech Activities in Emerging Countries: A

Network perspective on the Argentinean Biotech

Activity

UNU-MERIT/MGSoG Dissertation Series, № 78

\section{Kristine Farla}

Empirical Studies on Institutions, Policies and

Economic Development

MGSoG Dissertation Series, № 38

\section{Marina Petrovic}

Social Assistance and Activation in the Pursuit of

Happiness: Shedding New Light on Old Policy

Solutions to Social Exclusion

MGSoG Dissertation Series, № 37

\section{Laura Torvinen}

Assessing Governance Assessments: The Case of Mozambique: Governance Assessments in the Context of Aid Effectiveness Discourse

MGSoG Dissertation Series, № 36

\section{Biniam Egu Bedasso}

Institutional Change in the Long Shadow of Elite:

Essays on Institutions, Human Capital and Ethnicity in Developing Countries

MGSoG Dissertation Series, № 35

\section{Sepideh Yousefzadeh Faal Deghati}

Childhoods Embargoed: Constructing and

Reconstructing Multidimensional Child Poverty in Iran 1984-2009

MGSoG Dissertation Series, № 34

\section{Robert Bauchmüller}

Investing in Early Childhood Care and Education:

The Impact of Quality on Inequality

MGSoG Dissertation Series, № 33

\section{Martin Rehm}

Unified Yet Separated: Empirical Study on the Impact of Hierarchical Positions within Communities of Learning

MGSoG Dissertation Series, № 32

2012

\section{Abdul Waheed \\ Innovation Determinants and Innovation as a Determinant: Evidence from Developing Countries \\ UNU-MERIT Dissertation Series, № 77}

\section{Bilal Mirza}

Energy Poverty and Rural Energy Markets in Pakistan

UNU-MERIT Dissertation Series, № 76

\section{Benjamin Engelstätter}

Enterprise Software and Video Games: An Empirical Analysis

UNU-MERIT Dissertation Series, № 75

\section{Fulvia Farinelli}

Natural Resources, Innovation and Export Growth: The Wine Industry in Chili and Argentina UNU-MERIT Dissertation Series

\section{Rodolfo Lauterbach}

Innovation in Manufacturing: From Product Variety and Labor Productivity Growth to Economic Development in Chile

UNU-MERIT Dissertation Series

\section{Kirsten Wiebe}

Quantitative Assessment of Sustainable Development and Growth in Sub-Saharan Africa UNU-MERIT Dissertation Series, № 74

\section{Julio Miguel Rosa}

Organizational Strategies, Firms' Performance and Spatial Spillovers: The Canadian Case in Research and Development.

UNU-MERIT Dissertation Series, № 73

\section{Johannes Wilhelmus Marie Boels} Joseph Schumpeter, Honderd Jaar Economische Ontwikkeling: Een Historisch-theoretische Beschouwing. UNU-MERIT Dissertation Series 


\section{Dorcas Mbuvi}

Utility Reforms and Performance of the Urban Water Sector in Africa

MGSoG Dissertation Series, № 31

\section{Lina Salanauskaite}

Distributional Impacts of Public Policies: Essays in Ex-Ante and Ex-Post Evaluation

MGSoG Dissertation Series, № 30

\section{Esther Schüring}

To Condition or not - is that the Question? An Analysis of the Effectiveness of Ex-Ante and ExPost Conditionality in Social Cash Transfer Programs

MGSoG Dissertation Series, № 29

\section{Joe Abah}

Strong Organisations in Weak States: Atypical

Public Sector Performance in Dysfunctional

Environments

MGSoG Dissertation Series, № 28

\section{Zina Samih Nimeh}

Social Citizenship Rights: Inequality and Exclusion MGSoG Dissertation Series, № 27

\section{1}

\section{Daniel Vertesy}

Interrupted Innovation: Emerging Economies in the Structure of the Global Aerospace Industry UNU-MERIT Dissertation Series, № 72

\section{Tina Saebi}

Successfully Managing Alliance Portfolios:

AnAlliance Capability View

UNU-MERIT Dissertation Series, № 71

\section{Nora Engel}

Tuberculosis in India: A Case of Innovation and Control

UNU-MERIT/MGSoG Dissertation Series, № 70

\section{Evans Mupela}

Connectivity and growth in Sub-Saharan Africa: The Role of Communication Satellites

UNU-MERIT Dissertation Series, № 69

\section{Nantawan Kwanjai}

Cross Cultural Intelligence amid Intricate Cultural Webs: A Tale of the UnDutchables in the Land of 1002 Smiles

UNU-MERIT Dissertation Series, № 68

\section{Lina Sonne}

Innovation in Finance to Finance Innovation: Supporting Pro-poor Entrepreneur-based Innovation UNU-MERIT Dissertation Series, № 67

\section{Lenka Eisenhamerová}

Legitimacy of 'Humanitarian Military Intervention' MGSoG Dissertation Series, № 26

\section{Sonila Tomini}

Informal Payments for Health Care Services in Albania

MGSoG Dissertation Series, № 25

Jinjing Li

Dynamic Microsimulation in Public Policy

Evaluation

MGSoG Dissertation Series, № 24

\section{Aziz Atamanov}

Rural Nonfarm Employment and International Migration as Alternatives to Agricultural Employment: The Case of Kyrgyzstan

MGSoG Dissertation Series, № 23

\section{Frieda Vandeninden}

Poverty Alleviation: Aid and Social Pensions MGSoG Dissertation Series, № 22

\section{Juliana Nyasha Tirivayi}

The Welfare Effects of Integrating AIDS Treatment with Food Transfers: Evidence from Zambia MGSoG Dissertation Series, № 21

\section{Agnieska Ewa Sowa}

Who's Left Behind? Social Dimensions of Health Transition and Utilization of Medical Care in Poland MGSoG Dissertation Series, № 20

\section{Emmanaouil Sfakianakis}

The Role of Private Actors in the Provision of Public Goods with Applications to Infrastructure and Financial Stability MGSoG Dissertation Series, № 19 


\section{Siu Hing Lo}

White Collars Green Sleeves: An Inter-organizational Comparison of Determinants of Energy-Related

Behaviors among Office Workers

MGSoG Dissertation Series, № 18

\section{Treena $\mathbf{W u}$}

Constraints to Human Capital Investment in

Developing Countries:

Using the Asian Financial Crisis in Indonesia as a

Natural Experiment

MGSoG Dissertation Series, № 17

\section{Henry Espinoza Peña}

Impact Evaluation of a Job-Training Programme for

Disadvantaged Youths:

The Case of Projoven

MGSoG Dissertation Series, № 16

2010

Fernando Santiago

Human Resources Management Practices and

Learning for Innovation in Developing Countries:

Pharmaceutical Firms in Mexico

UNU-MERIT Dissertation Series, № 66

\section{Zakaria Babutsidze}

Essays on Economies with Heterogeneous Interacting Consumers

UNU-MERIT Dissertation Series, № 65

\section{Bertha Vallejo}

Learning and Innovation Under Changing Market

Conditions: The Auto Parts Industry in Mexico

UNU-MERIT Dissertation Series, № 64

\section{Donatus Ayitey}

Technical Change, Competitiveness and Poverty

Reduction: A Study of the Ghanaian Apparel

Industry

UNU-MERIT Dissertation Series, № 63

\section{Sergey Filippov}

Multinational Subsidiary Evolution: Corporate

Change in New EU Member States

UNU-MERIT Dissertation Series, № 62

\section{Asel Doranova}

Technology Transfer and Learning under the Kyoto Regime: Exploring the Technological Impact of CDM Projects in Developing Countries

UNU-MERIT Dissertation Series, № 61

\section{Florian Tomini}

Between Family and Friend: Understanding the Interdependency of Private Transfers

MGSoG Dissertation Series, № 15

\section{Michał Polalowski}

The Institutional Transformation of Social Policy in East Central Europe: Poland and Hungary in Comparative and Historical Perspective

MGSoG Dissertation Series, № 14

\section{Maha Ahmed}

Defining, Measuring and Addressing Vulnerability:

The Case of Post Conflict Environments

MGSoG Dissertation Series, № 13

\section{Pascal Beckers}

Local Space and Economic Success: The Role of Spatial Segregation of Migrants in the Netherlands MGSoG Dissertation Series, № 12

\section{Victor Cebotari}

Conflicting Demands in Ethnically Diverse Societies: Ethno political Contention and Identity Values in Europe

MGSoG Dissertation Series, № 11

\section{Dennis Gyllensporre}

Competing and Complementary Perspectives on the EU as a Crisis Management Actor:

An Examination of the Common Security and Defence Policy through the Lenses of Idealism and Realism

MGSoG Dissertation Series, № 10

\section{Judit Vall Castello}

Business Cycle and Policy Effects on Labour Market Transitions of Older and Disabled Workers in Spain MGSoG Dissertation Series, № 9

\section{Keetie Roelen}

False Positives or Hidden Dimensions: The Definition and Measurement of Child Poverty MGSoG Dissertation Series, № 8 


\section{Denisa Maria Sologon}

Earning Dynamics in Europe

MGSoG Dissertation Series, № 7

\section{Melissa Siegel}

Money and Mobility: Migration and Remittances

MGSoG Dissertation Series, № 6

\section{Jessica S. Hagen-Zanker}

Modest Expectations: Causes and Effects of

Migration on Migrant Households inSource

Countries

MGSoG Dissertation Series, № 5

2009

\section{Alexis Habiyaremye}

From Primary Commodity Dependence to

Diversification and Growth: Absorptive Capacity and

Technological Catch Up in Botswana and Mauritius.

UNU-MERIT Dissertation Series, № 60

\section{Yoseph Getachew}

The Role of Public Capital in Economic Development UNU-MERIT Dissertation Series, № 59

\section{Sandra Leitner}

Embodied Technological Change and Patterns of

Investment in Austrian Manufacturing

UNU-MERIT Dissertation Series, № 58

\section{Semih Akçomak}

The Impact of Social Capital on Economic and Social Outcomes

UNU-MERIT Dissertation Series, № 57

\section{Abraham Garcia}

The Role of Demand in Technical Change

UNU-MERIT Dissertation Series, № 56

\section{Saurabh Arora}

Coherence in Socio-technical Systems: A Network

Perspective on the Innovation Process

UNU-MERIT Dissertation Series, № 55

\section{Mirtha R. Muniz Castillo}

Human Development and Autonomy in Project Aid: Experiences from four bilateral projects in Nicaragua and El Salvador

MGSoG Dissertation Series, № 4
Christiane Arndt

Governance Indicators

MGSoG Dissertation Series, № 3

Britta Augsburg

Microfinance: Greater Good or Lesser Evil?

MGSoG Dissertation Series, № 2

2008

Rutger Daems

Medicines for the Developing World

UNU-MERIT Dissertation Series, № 54

\section{Johannes Hanel}

Assessing Induced Technology: Sombart's

Understanding of Technical Change in the History of

Economics

UNU-MERIT Dissertation Series, № 53

\section{Rifka Weehuizen}

Mental Capital: the Economic Significance of Mental Health

UNU-MERIT Dissertation Series, № 52

\section{Danielle Cloodt}

The Relationship between RED Partnership

Formation, Social Embeddedness and Innovative

Performance

UNU-MERIT Dissertation Series, № 51

\section{Sabine Fuss}

Sustainable Energy Development under Uncertainty UNU-MERIT Dissertation Series, № 50

\section{Geranda Notten}

Measuring and Managing Poverty Risks

MGSoG Dissertation Series, № 1

\section{7}

\section{Tobias Kronenberg}

Reconciling Environmental Conservation with Economic Prosperity: The Feasibility of Double Dividends in the Short and Long Run

UNU-MERIT Dissertation Series, № 49

\section{Viktoria Kravtsova}

Assessing the Impact of Foreign Direct Investment in Transition Economies

UNU-MERIT Dissertation Series, № 48 


\section{Suhail Sultan}

The Competitive Advantage of Small and Medium Sized Enterprises: The Case of Jordan's Natural Stone Industry

UNU-MERIT Dissertation Series, № 47

2006

\section{Bulat Sanditov}

Essays on Social Learning and Imitation

UNU-MERIT Dissertation Series, № 46

\section{Mamata Parhi}

Dynamics of New Technology Diffusion: A Study of the Indian Automotive Industry

UNU-MERIT Dissertation Series, № 45

\section{Andreas Reinstaller}

Social Structures and the Innovation Process: Their Role in the Demand of Firms and Consumers

UNU-MERIT Dissertation Series, № 44

\section{Rose Kiggundu}

Innovation systems and Development: The Journey of a Beleaguered Nile Perch Fishery in Uganda

UNU-MERIT Dissertation Series, № 43

\section{Thomas Pogue}

The Evolution of Research Collaboration in South African Gold Mining: 1886-1933

UNU-MERIT Dissertation Series, № 42

\section{Geoffrey Gachino}

Foreign Direct Investment, Spillovers and Innovation: The Case of Kenyan Manufacturing Industry

UNU-MERIT Dissertation Series, № 41

\section{Önder Nomaler}

Technological Change, International Trade and Growth: An Evolutionary, Multi-Agents-Based Modeling Approach

UNU-MERIT Dissertation Series, № 40

2005

\section{Samia Satti Osman Mohamed-Nour}

Change and Skill Development in the Arab Gulf Countries

UNU-MERIT Dissertation Series, № 39

\section{Elad Harison}

Intellectual Property Rights: Economics and Policy Analysis

UNU-MERIT Dissertation Series, № 38

\section{Daniel Dalohoun}

The Relationship between RED Partnership Formation, Social Embeddedness and Innovative Performance: a Multi-level Approach of Social Embeddedness

UNU-MERIT Dissertation Series, № 37

\section{Müge Ozman}

Networks, Organizations and Knowledge UNU-MERIT Dissertation Series, № 36

\section{Bas Straathof}

Product Variety and Economic Growth: The Counteracting Effects of Scale and Idiosyncrasy UNU-MERIT Dissertation Series, № 35

\section{Wilfred Schoenmakers}

Knowledge Flows between Multinational Companies: A Patent Data Analysis

UNU-MERIT Dissertation Series, № 34

\section{Myriam Cloodt}

Mergers and Acquisitions ( $M$ and As) in High-Tech Industries: Measuring the Post-M and A Innovative Performance of Companies

UNU-MERIT Dissertation Series, № 33

\section{4}

\section{Paola Criscuolo}

RED Internationalisation and Knowledge Transfer: Impact on MNEs and their Home Countries UNU-MERIT Dissertation Series, № 32

\section{Maarten Verkerk}

Trust and Power on the Shop Floor

UNU-MERIT Dissertation Series, № 31

\section{Gottfried Leibbrandt}

Adoption, Harmonization and Succession of Network Technologies across Countries

UNU-MERIT Dissertation Series, № 30 


\section{Mark Sanders}

Skill Biased Technical change: Its Origins, the Interaction with the Labour Market and Policy Implications

UNU-MERIT Dissertation Series, № 29

2003

\section{Nadine Roijakkers}

Inter-firm Cooperation in High-tech Industries: a Study of RED Partnerships in Pharmaceutical Biotechnology

UNU-MERIT Dissertation Series, № 28

\section{Viki Sonntag}

Speed, Scale and Sustainability

UNU-MERIT Dissertation Series, № 27

\section{Masaru Yarime}

From End-of-Pipe Technology to Clean Technology UNU-MERIT Dissertation Series, № 26

\section{Stéphane Malo}

The Combinatorial Chemistry Revolution: Sustaining a Superior Performance Position through Technological Learning UNU-MERIT Dissertation Series, № 25

2002

\section{Annelies Hogenbirk}

Determinants of Inward Foreign Direct Investment: the Case of the Netherlands

UNU-MERIT Dissertation Series, № 24

\section{Bastiaan Johan terWeel}

The Computerization of the Labour Market

UNU-MERIT Dissertation Series

\section{1}

\section{John Adeoti}

Technology Investment in Pollution Control in SubSaharan Africa: The Case of the Nigerian

Manufacturing Industry

UNU-MERIT Dissertation Series, № 23

\section{Edward Huizenga}

Innovation Management: How Frontrunners Stay Ahead: An Empirical Study on Key Success Factors in the ICT sector UNU-MERIT Dissertation Series, № 22
2000

\section{Machiel van Dijk}

Technological Change and the Dynamics of Industries: Theoretical Issues and Empirical evidence from Dutch Manufacturing

UNU-MERIT Dissertation Series, № 21

\section{9}

\section{Jan Cobbenhagen}

Managing Innovation at the Company Level: A Study on Non-Sector-Specific Success Factors UNU-MERIT Dissertation Series, № 20

\section{Marjolein Caniëls}

Regional Growth Differentials: The Impact of Locally Bounded Knowledge Spillovers

UNU-MERIT Dissertation Series, № 19

\section{8}

\section{Aldo Geuna}

Resource Allocation and Knowledge production: Studies in the Economics of University Research UNU-MERIT Dissertation Series, № 18

\section{6}

\section{Reinoud Joosten}

Dynamics, Equilibria, and Values

UNU-MERIT Dissertation Series, № 17

\section{Hugo Kruiniger}

Investment, RED, and the Financing Decisions of the Firm

UNU-MERIT Dissertation Series, № 16

1995

\section{Hans van Meijl}

Endogenous Technological Change: The Case of Information Technology, Theoretical Considerations and Empirical Results

UNU-MERIT Dissertation Series, № 15

\section{René Kemp}

Environmental Policy and Technical Change: A

Comparison of the Technological Impact of Policy

Instruments

UNU-MERIT Dissertation Series, № 14 
Rohini Acharya

The Impact of New Technologies on Economic Growth and Trade: A Case Study of Biotechnology

UNU-MERIT Dissertation Series, № 13

\section{Geert Duysters}

The Evolution of Complex Industrial Systems: The Dynamics of Major IT Sectors

UNU-MERIT Dissertation Series, № 12

\section{Marjan Groen}

Technology, Work and Organisation: A Study of the Nursing Process in Intensive Care Units

UNU-MERIT Dissertation Series, № 11

1994

\section{Huub Meijers}

On the Diffusion of Technologies in a Vintage

Framework: Theoretical Considerations and

Empirical Results

UNU-MERIT Dissertation Series, № 10

\section{Theon van Dijk}

The Limits of Patent Protection: Essays on the Economics of Intellectual Property Rights UNU-MERIT Dissertation Series, № 9

\section{Hans Voordijk}

Naar Integrale Logistiek in Bedrijfsketens:

Ontwikkelingen in de Bouw

UNU-MERIT Dissertation Series, № 8

1993

\section{Paul Diederen}

Technological Progress in Enterprises and Diffusion of Innovation: Theoretical Reflections and Empirical Evidence

UNU-MERIT Dissertation Series, № 7

\section{Ben Dankbaar}

Economic Crisis and Institutional Change: The Crisis of Fordism from the Perspective of the Automobile Industry

UNU-MERIT Dissertation Series, № 6

\section{Hanno Roberts}

Accountability and Responsibility: The Influence of Organisation Design on Management Accounting UNU-MERIT Dissertation Series, № 5

\section{2}

\section{Bart Verspagen}

Uneven Growth between Interdependent Economies: An Evolutionary View on Technology Gaps, Trade and Growth

UNU-MERIT Dissertation Series, № 4

\section{Sjoerd Romme}

A Self-organization Perspective on Strategy

Formation

UNU-MERIT Dissertation Series, № 3

\section{9}

\section{John Spangenberg}

Economies of Scale, and Atmosphere in Research Organisations

UNU-MERIT Dissertation Series, № 2

\section{8}

\section{John Hagedoorn}

Evolutionary and Heterodox Innovation Analysis: A Study of Industrial and Technological Development in Process Control and Information Technology UNU-MERIT Dissertation Series, № 1 

